\title{
Produtividade do capim-Tanzânia (Panicum maximum Jacq. cv. Tanzânia) em função da lâmina de irrigação e de adubação nitrogenada
}

\section{LUÍS GERALDO TEIXEIRA SORIA}

\author{
Tese apresentada à Escola Superior de \\ Agricultura "Luiz de Queiroz", Universidade \\ de São Paulo, para obtenção do título de \\ Doutor em Agronomia, Área de Concentração: \\ Irrigação e Drenagem.
}

\section{PIRACICABA}

Estado de São Paulo - Brasil

Novembro - 2002 


\title{
Produtividade do capim-Tanzânia (Panicum maximum Jacq. cv. Tanzânia) em função da lâmina de irrigação e da adubação nitrogenada
}

\section{LUÍS GERALDO TEIXEIRA SORIA \\ Engenheiro Agrônomo}

Orientador: Prof. Dr. RUBENS DUARTE COELHO

\begin{abstract}
Tese apresentada à Escola Superior de Agricultura "Luiz de Queiroz", Universidade de São Paulo, para obtenção do título de Doutor em Agronomia, Área de Concentração: Irrigação e Drenagem.
\end{abstract}

PIRACICABA

Estado de São Paulo - Brasil

Novembro - 2002 
Dados Internacionais de Catalogação na Publicação (CIP) DIVISÃO DE BIBLIOTECA E DOCUMENTAÇÃO - ESALQ/USP

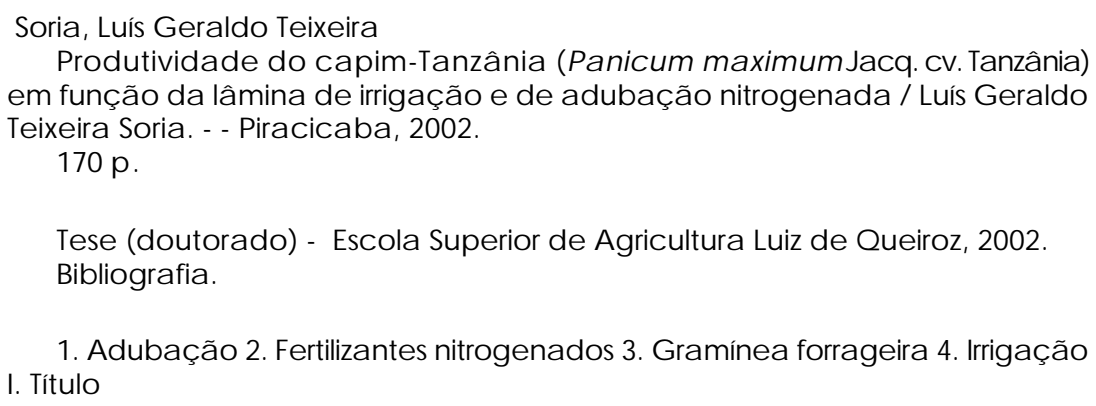

CDD 633.2

\section{"Permitida a cópia total ou parcial deste documento, desde que citada a fonte - $O$} autor" 
Dedico a Aloyséia Crsitina da Silva

Noronha, mulher mais que especial e a quem muito devo ... 


\section{AGRADECIMENTOS}

À Natureza, mãe de todas as crias, geradora e transformadora de minha vida como indivíduo para a busca de um mundo comunitário e fraterno;

À direção atual da Escola Agrotécnica Federal de Catú-Ba, por acreditar que somente através de um treinamento ao nível de pós-graduação de seus professores, estes poderão serem capazes de contribuir regionalmente com um trabalho de transformação social, educacional e moral, através da melhora de qualidade técnicas e profissional de seus alunos junto a suas comunidades nelas representada;

Ao Prof. Dr. Marcos Vinícius Folegatti, por ter acreditado em minha capacidade profissional, e proporcionado condições para desenvolvimento deste doutorado;

Ao Prof. Dr. Rubens Duarte Coelho, pela verdadeira amizade gerada nestes quatro anos, ensinamentos oferecidos, pela orientação e pelo incentivo sempre dados;

À Escola Superior de Agricultura "Luiz de Queiroz" (ESALQ/USP), através do Departamento de Engenharia Rural, pelo apoio dispensado e pelo acolhimento;

Ao Conselho Nacional de Desenvolvimento Científico e Tecnológico (CNPq), pela concessão de bolsa de estudos;

À Fundação de Auxílio à Pesquisa do Estado de São Paulo (FAPESP), pelo suporte financeiro dessa pesquisa, de acordo com o projeto n 99/12582-5: Funções de resposta "Produtividade do capim Tanzânia (Panicum maximum Jacq cv. Tanzânia) em função da lâmina de irrigação e doses de nitrogênio";

À Netafim Brasil pela doação dos tubos gotejadores para a irrigação da área experimental; 
Aos Pesq. do IAC Dr. Odair Bovi, cuja participação na minha formação científica começou em 1988, e de depois pelos empurrões os quais permitiram com que consegui-se obter o meu Mestrado e agora o Doutorado.;

Aos Profs. Dr. Valdo Rodrigues Herling e Dr. Pedro Henrique de Cerqueira Luz, pelas valiosas sugestões e pelas colaborações;

Ao colega Valter, pelo companheirismo e ajuda na condução do experimento de campo, no qual teria sido impossível o seu desenvolvimento;

Ao mestrando Leandro Fellet Lourenço (UFA) e ao Grupo de Práticas em Irrigação e Drenagem (GPID), em nome de Ithamar, Adriano, Rafael, Alex, Camila, Vivian, Marcos, pela ajuda na coleta de dados de campo, pelo companheirismo e pela amizade ;

Aos professores e colegas do Curso de Pós-Graduação em Irrigação e Drenagem, que, formal ou informalmente, contribuíram com sua amizade em uma melhora de minha formação científica;

Aos amigos aqui feitos, Alexandre, Diniz, Nicolas, José Roberto, Olívio pelo companheirismo e pela amizade que espero nunca cesse ;

Aos funcionários do DER-ESALQ/USP, Davilmar, Sandra, César, Hélio, Antônio, Gilmar e Osvaldo, pelo apoio e pela atenção;

À Academia Sport Center, principalmente ao Sr Getulino e Prof. Carlos, que proporcionaram através de um treinamento físico anti-estresse e condição de ambiente adequado, condições para que idéias e soluções para problemas fossem encontradas após muito suor realmente físico; 


\section{SUMÁRIO}

\begin{tabular}{|c|c|}
\hline \multicolumn{2}{|l|}{ 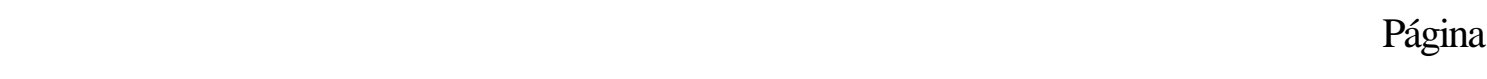 } \\
\hline RESUMOO. & viii \\
\hline SUMMARY & \\
\hline 1 INTRODUÇÃO............................... & 1 \\
\hline 2 REVISÃO DE LITERATURA............... & 3 \\
\hline 2.1 A planta & 3 \\
\hline 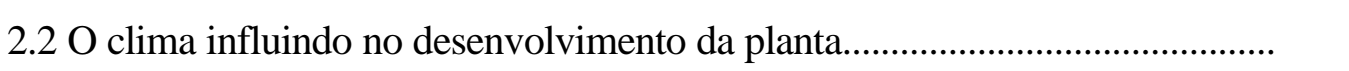 & 4 \\
\hline 2.2.1 Temperatura ...... & 4 \\
\hline 2.2.2 Água ......... & 5 \\
\hline 2.2 .3 Luz & 7 \\
\hline 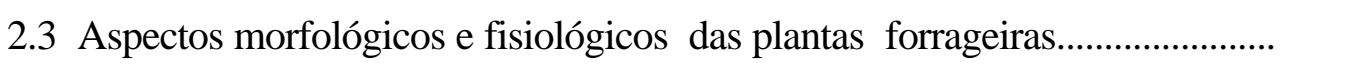 & 8 \\
\hline 2.3.1 Morfogênese .......... & 8 \\
\hline 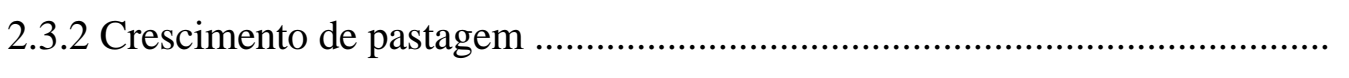 & 9 \\
\hline 2.4 Estacionalidade & 11 \\
\hline 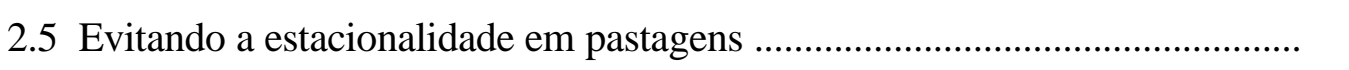 & 12 \\
\hline 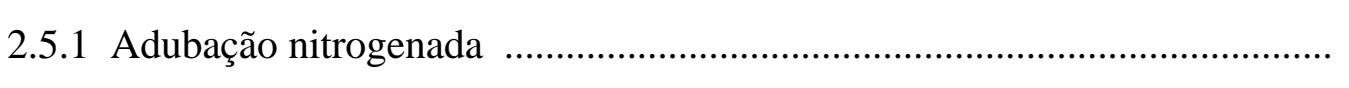 & 13 \\
\hline 2.5.2 Uso da Irrigação em pastagens .. & 15 \\
\hline 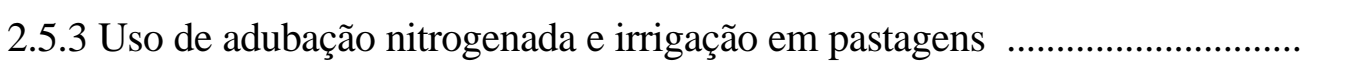 & 17 \\
\hline 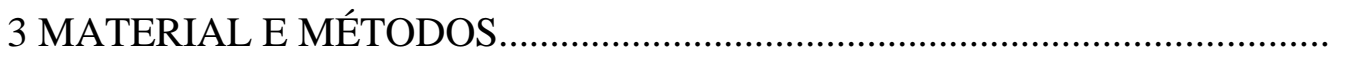 & 19 \\
\hline 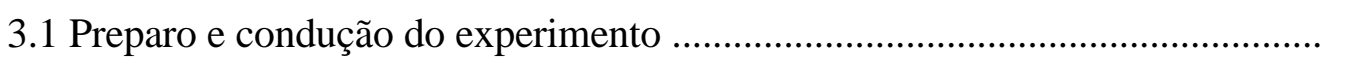 & 19 \\
\hline 3.2 Manejo e condução da Irrigação .................. & 20 \\
\hline 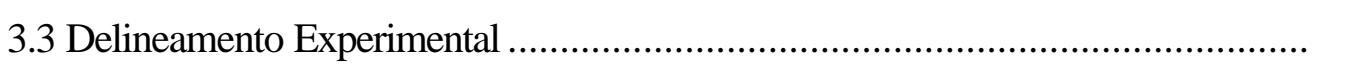 & 22 \\
\hline & 24 \\
\hline
\end{tabular}


3.4.1 Produção de Forragem ……………………………….................................. 24

3.4.2 Determinação de Índices de Eficiências ..................................................... 24

3.4.2.1 Eficiência de uso da água (EUA) ............................................................ 24

3.4.2.2 Índice de Produção de Fitomassa (IPB)..................................................... 25

3.4.2.3 Eficiência de uso do nitrogênio (EUN) ……………………………....... 25

3.4.2.4 Eficiência Fisiológica do N absorvido (EFNabs) ........................................ 26

3.4.2.5 Nitrogênio aparentemente recuperado (NapRec) ……................................ 26

3.4.3 Análise Bromatológica .......................................................................... 26

4 RESULTADOS E DISCUSSÃO..................................................................... 28

4.1 Variação estatística na produção de massa seca ................................................. 28

4.2 Avaliação da fertilidade na área experimental ................................................ 32

4.3 Avaliação do efeito do uso de lâminas de irrigação........................................... 40

4.3.1 Variação do clima .......................................................................................

4.3.2 Variação de água no solo ............................................................................. 47

4.3.3 Movimento da água através do perfil do solo ................................................ 71

4.4. Avaliação do efeito do uso de adubação nitrogenada ......................................

4.4.1 Produção de massa seca total ........................................................................

4.4.2 Produção de massa seca foliar e de hastes ……………………………...... 90

4.4.3 Produção de massa seca total, foliar e de hastes nas diferentes estações de 94 coleta

4.4.4 Produção de massa seca dentro do ano agrícola (2000/2001)....................... 96

4.5 Índices relacionados a produção de massa seca ............................................... 100

4.5.1 Eficiência de uso de água ( EUA) ............................................................... 100

4.5.2 Eficiência de uso do nitrogênio (EUN) ........................................................ 108

4.6 Análise Bromatológica .............................................................................. 121

4.7 Análise econômica simples avaliando o uso do fertilizante aplicado ............... 134

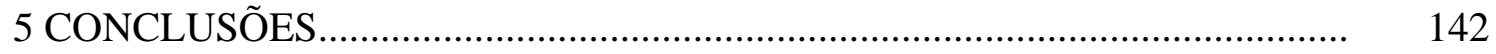

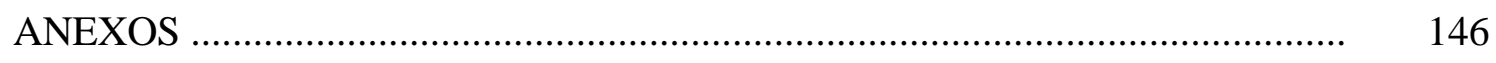

REFERÊNCIAS BIBLIOGRÁFICAS............................................................ 151 


\title{
PRODUTIVIDADE DO CAPIM-TANZÂNIA (Panicum maximum Jacq. cv. TANZÂNIA) EM FUNÇÃO DA LÂMINA DE IRRIGAÇÃO E DA ADUBAÇÃO NITROGENADA
}

\author{
Autor: LUÍS GERALDO TEIXEIRA SORIA \\ Orientador: Prof. Dr. RUBENS DUARTE COELHO
}

\section{RESUMO}

Objetivou-se estudar o efeito de diferentes lâminas de água aplicada e adubação nitrogenada e suas interações, durante nove ciclos de crescimento do capim Tanzânia, quantificando os fatores de crescimento, de produção, de eficiência de uso e de qualidade de forragem. A determinação de funções de produção para massa seca total, foliar e de haste , buscando encontrar o nível de máximo de produção e econômico de cada fator de produção analisado, baseou-se em um delineamento em blocos em modelo de parcela sub-sub-dividida, na qual nas parcelas foram distribuídas as diferentes lâminas de irrigação $(0,30,70,100$ e $150 \% \mathrm{CC})$, nas sub-parcelas as doses de nitrogênio $\left(0,100,275,756\right.$ e $\left.2079 \mathrm{~kg} \mathrm{~N} \cdot \mathrm{ha}^{-1} \mathrm{ano}^{-1}\right)$ e nas sub-sub-parcelas os três períodos climáticos (verão, inverno e primavera) constituídos de 3 coletas . A ocorrência da estacionalidade na produção de massa seca total em Piracicaba é algo característico da região, onde o efeito da irrigação como manejo complementar e o uso de nitrogênio para aumentar a produção do capim Tanzânia no inverno não se mostraram capazes de diminuírem o efeito de significativo dos fatores climáticos. As maiores lâminas de irrigação proporcionaram efeitos negativos sobre a produção de mateira seca, , sendo o tratamento visando repor a umidade no solo a $70 \% \mathrm{CC}$ o que proporcionou os maiores valores de eficiência uso da água (EUA) com a irrigação suplementar quando observado a sua variação temporal. $O$ aumento das doses de nitrogênio dentro dos diferentes períodos de coletas, permitiram aumentos nas produções de massa seca totais, 
e aumento nos valores de concentração de nitrogênio total, nitrogênio absorvido, Proteína Bruta (PB) e nos valores de digestibilidade "ï n vitro" da matéria orgânica (DIVMO), com redução nos valores de eficiência de uso do nitrogênio (EUN) e a eficiência fisiológica do $\mathrm{N}$ absorvido (EFNabs) . Dosagens de nitrogênio superiores a $756 \mathrm{Kg} \mathrm{N} . \mathrm{ha}^{-1}$.ano ${ }^{-1}$ não proporcionaram efeitos crescentes sobre a produção de massa seca, somente uma melhora na qualidade da forragem, com aumento de PB e DIVMO, e não variação do FDA. O uso de doses de nitrogênio até o máximo de 275 kg N.ha ${ }^{-}$ ${ }^{1}$.ano ${ }^{-1}$ mostraram maiores EUN e EFNabs do que quando usados doses acima de $756 \mathrm{~kg}$ N.ha ${ }^{-1}$.ano ${ }^{-1}$, a qual proporcionou maior porcentagem de nitrogênio recuperado ( $40 \%$ quando irrigado e de $33 \%$ não irrigado). A relação entre preço de compra e o teor de nutriente no fertilizante deve ser o fator preponderantemente pelo pecuarista, quando do momento de aquisição do fertilizante nitrogenado para adubação de pastagem de capim Tanzânia. 


\title{
PRODUCTIVITY OF TANZANIA GRASS (Panicum maximum Jacq. cv. TANZANIA) DUE TO IRRIGATION DEPTHS AND NITROGEN FERTILIZER
}

\author{
Author: LUÍS GERALDO TEIXEIRA SORIA \\ Adviser: Prof. Dr. RUBENS DUARTE COELHO
}

\section{SUMMARY}

The aim of this study was to evaluate the different effects of applied irrigation dephts and nitrogen fertilizer on nine growing cycles of Tanzania grass, quantifying growing factors, production, efficiency and the forage quality. The production function determination for total dry material, leaf and stem, attempting to find the maximum level of the economic production of each factor, was based on a complete randomised block experiment using split-split-plot model design, in which the plots were distributed in different levels of irrigation (0, 30, 70,100 e 150\% Field Capacity - CC), in the splitplot the nitrogen doses $\left(0,100,275,756\right.$ e $2079 \mathrm{~kg} \mathrm{~N} \mathrm{ha}^{-1}$.year $\left.{ }^{-1}\right)$ and in the split-splitplot the nine growing cycles were grouped in three major climatic periods (summer, winter and spring). The occurrence of a seasonal pattern herbage production of the total dry material in Piracicaba is a characteristic feature of this region, where the effects of irrigation and nitrogen as complementing management tools during the winter time, did not prove to be capable of decreasing the meaningful effect of the climatic factors. The higher water dephts (100 and 150\% CC) resulted negative effects on the production of dry material, compare to the $70 \% \mathrm{CC}$ treatment, which proved to have higher values of water use efficency. The increase of nitrogen doses inside the growing cycles, promoted an increase on the: total dry material, total nitrogen concentration, absorbed nitrogen, 
crude protein $(\mathrm{PB})$ and "in vitro" organic material digestibility (DIVMO), reducing the values of the efficiency of the use of nitrogen (EUN) and the physiologic efficiency of the $\mathrm{N}$ absorbed (EFNabs). The use of higher nitrogen doses above $756 \mathrm{Kg} \mathrm{N}^{-h a}{ }^{-1}$.year, did not promote increasing effects on the production of dry material, only the improvement in the forage quality, increasing the PB and DIVMO values and no variation of FDA. The use of nitrogen doses until the maximum value of $275 \mathrm{Kg} \mathrm{N} / \mathrm{ha}$ year, showed higher EUN and EFNabs than doses above $256 \mathrm{Kg}$ N/ha year, which promote the increase of recovered nitrogen (40\% when irrigated and 33\% not irrigated). The relation between purchase price and nutrient concentration in the fertilizer must be the most preponderant aspect by the cattle raiser considered for the fertilization of Tanzania grass pasture. 


\section{INTRODUÇÃo}

As pastagens apresentam estacionalidade de crescimento durante o ano; todavia atingem, em determinado momento, sua melhor qualidade de pastejo, dependente das condições climáticas: temperatura, luminosidade e disponibilidade hídrica (Vallentine, 1990).

A escolha de técnicas que equacionem o problema decorrente da estacionalidade de produção das plantas forrageiras deve ser coerente com o nível da exploração pecuária. A técnica de irrigação em pastagens durante o período de estiagem no Brasil Central, associada à adubação nitrogenada, em trabalhos experimentais, tem mostrado aumento na produção entre 20 e $70 \%$ sobre a testemunha no período de 150 dias(Corsi, 1978 citado por Rolim,1994).

A resposta à associação entre a adubação nitrogenada e a irrigação tem sido detectada tanto no período seco, como no das chuvas, visando a suprir veranicos nesse período. Estudando a produção dos capins sempre-verde (Panicum maximum.), gordura (Melinis minutiflora Pal de Beauv.) e pangola (Digitaria decumbens Steut), no município de Viçosa (M.G.), Ladeira et al. (1966) observaram que o uso simultâneo de adubação nitrogenada (45 kg N.ha ${ }^{-1}$.ano ${ }^{-1}$ ) e irrigação no período seco, proporcionou produções de massa verde $24 \%$ superiores à testemunha. Resultados semelhantes foram obtidos por Ararat \& Tafur (1990). O uso em associação de tais fatores pode proporcionar mudanças nos teores de proteína das plantas forrageiras (Dias et al. ,1998).

Apesar da importância da interação nitrogênio-água nos aspectos quantitativos e qualitativos das forragens, poucos estudos foram conduzidos no Brasil, definindo as dosagens ideais desses fatores. $\mathrm{O}$ presente trabalho de pesquisa teve como objetivo 
básico definir as dosagens de nitrogênio e água, para otimizar a produção de forragem do capim-Tanzânia, no Estado de São Paulo, criando-se a oportunidade de ampliar o conhecimento do efeito da lâmina total de água aplicada, da adubação nitrogenada e de suas interações nos fatores de crescimento, de produção e de qualidade de forragem de capim Tanzânia, buscando-se, encontrar os níveis econômicos ótimos de cada fator de produção analisado. 


\section{REVISÃO DE LITERATURA}

\subsection{A planta}

As pastagens do gênero Panicum pertencem à família Gramínea , tribo Paniceae, apresentando cerca de 81 gêneros e mais de 1460 espécies, no qual o capim Panicum maximum Jacq., planta de origem africana, é tido como uma das gramíneas mais difundidas no Brasil, sendo em área a principal gramínea cultivada em pastagens. No Estado de São Paulo, no ano de 1995, sua área de cultivo era de aproximadamente 395.799 hectares (CATI, 2002), valor inferior àquele encontrado no ano de 1978 de 2.950.000 hectares, correspondente a $32 \%$ da área total de pastagem no Estado (Carriel et al., 1979), redução causada possivelmente pela substituição por capins do gêneros Bachiaria.

Essa gramínea tem como característica apresentar diferentes denominações, que são dadas em função das diferentes cultivares encontradas e distribuídas pelas principais áreas de pastagem. Além da cultivar mais conhecida no Brasil, capim colonião, têm-se também as seguintes cultivares: búfalo, colonião deodoro, colonião de Tangânica, colonião sul-africano, coloninho, "gatton panic", "green panic", guiné, guinezinho, Makueni, Tobiatã, touceira, Mombaça e Tanzânia (Aronovich, 1995).

O capim Panicum maximum. é descrito como uma cultura perene, formadora de touceiras com sistema radicular profundo, com altura variável entre 60 a $200 \mathrm{~cm}$, limbos foliares verde escuro com $35 \mathrm{~mm}$ de largura que ão reduzindo-se para terminar em pontas finas; panículas com 12 a $40 \mathrm{~cm}$ de altura (Skerman \& Riveros, 1992). A 
profundidade de seu sistema radicular varia, em condições favoráveis, de 45 a $150 \mathrm{~cm}$ de profundidade ( Molinari, 1952)

\subsection{O clima influindo no desenvolvimento da planta.}

Os ciclos de crescimento das gramíneas são em muito influenciados por alguns fatores climáticos, tais como a temperatura, água e luz, os quais determinam de modo marcante todo o desenvolvimento dessas plantas, quando não considerando o potencial genético da planta.

\subsubsection{Temperatura}

Os capins do gênero Panicum, encontram se distribuídos dentro de uma faixa bastante ampla do globo terrestre que vai desde $40^{\circ} \mathrm{S}$ até $50^{\circ} \mathrm{N}$ de latitude, com predominância na zona equatorial úmida $\left(20^{\circ} \mathrm{S}\right.$ a $\left.20^{\circ} \mathrm{N}\right)$, e com uma variação em altitude que vai do nível do mar até aproximadamente 2.000 m (Skerman \& Riveros, 1992).

A temperatura afeta principalmente o crescimento das plantas no decorrer das estações do ano, através de sua variação temporal, no qual com a sua diminuição nos períodos de outono e inverno, vem influenciar de modo direto e indireto o metabolismo das plantas, afetando principalmente a fotossíntese (temperaturas abaixo do máximo ideal fotossintético) e absorção e translocação de nutrientes (Silva, 1995; Eastin \& Sullivan, 1984), e quando a umidade no solo não é limitante.

As gramíneas do gênero Panicum são plantas sensíveis às geadas (Skerman \& Riveros, 1992), onde a severidade por geada estão positivamente associada a quantidade de serrapilheira sobre o solo. A perda de calor à noite, acumulado durante todo o dia pela liteira na superfície do solo, diminui o perigo das geadas para as plantas (Humphreys, 1991). O perigo das geadas pode ser mais significativo, quando o pasto recém pastejado ou cortado, apresenta elevado número de brotações e área foliar desenvolvida. 


\subsection{2 Água}

Mcdowell ${ }^{1}$ citado por Rolim (1994), ao analisar o problema de produção de forragens em clima tropical, mostrou que a temperatura e a deficiência hídrica seriam as principais causas limitantes para a produção de forragens entre as latitudes $30^{\circ} \mathrm{N}$ e S. Estes dois elementos, podem individualmente (quando limitado pela temperatura $-36 \%$, e por deficiência hídrica - 31\%, ou em associação (24\%) limitar o crescimento das plantas forrageiras, quando estimado em porcentagem de área de terra total afetada pela temperatura e "déficit" hídrico.

Para o gênero Panicum, a umidade do solo representa fator importante juntamente com a temperatura. A distribuição das diferentes tribos estão relacionadas com áreas nas quais apresentam índices pluviométricos anuais superiores a $780 \mathrm{~mm}$, com preferência por precipitações de 1.000 mm anuais (Skerman \& Riveros, 1992).

Por apresentarem raízes não muito profundas, com predominância a $60 \mathrm{~cm}$, são plantas que não toleram secas intensas (Skerman \& Riveros, 1992), apresentando as vezes maior demanda por água do que culturas agrícolas. As gramíneas apresentam coeficientes de transpiração variáveis, podendo estar entre 300 a 400 mm, e quando apresentam deficiência de nutrientes ou em altas temperaturas extremas podem chegar a 700-800 mm por estação de crescimento (Petr et al., 1988). Esse coeficiente de transpiração é um índice que mede a ineficiência de uso da água, no qual plantas sem déficit hídrico, bem adubadas, produziriam mais por volume de água consumido.

Assim, em regiões tropicais, as altas temperaturas e intensidade luminosas favoreceriam altas taxas de evapotranspiração e que poderiam produzir "déficit" hídricos estacionais, provocando alterações no desenvolvimento das plantas (Machado et al., 1983); sendo mais significativos para as pastagens, uma vez sendo o volume de massa verde a principal necessidade nessa atividade econômica, a variação na disponibilidade de água poderia reduzir a sua produção (Sutcliffe, 1980).

\footnotetext{
${ }^{1}$ MACDOWELL,R.E. Improvement of livestock production in ward climates. S.Francisco: W.H.Freeman, 1972. 711 p.
} 
Machado et al. (1983), buscando determinar sob condição de campo a tolerância ao déficit hídrico em quatro gramíneas, encontraram que a Brachiaria humidicola (Rendle) Schweickerdt em um regime seco, apresentavam valores de potencial de água na folha logo pela manhã em torno de - 0,9 $\mathrm{MPa}$, chegando atingir valores de $-2,1 \mathrm{MPa}$ e alta resistência estomática,próxima a $20 \mathrm{seg} . \mathrm{cm}^{-1}$, o que indicaria pouca adaptabilidade desse capim a ambientes secos. Já as gramíneas Andropogon gayanus Kunth. e Cenchrus ciliaris L. cvs. "Gayndah" e "Biloela" mostraram elevados potenciais na folha (-1,9 MPa) e baixas resistências estomáticas, o que indica maior resistência a ambientes secos, no qual permitiriam ainda atividade fotossintética, como demostrado pelos maiores comprimentos de limbo foliar e altura de perfilho. Essa resposta seria em parte, ao fato de possuírem este capins maiores sistemas radiculares e folhas pilosas, permitindo suportarem estiagens superiores a 120 dias.

Assim, a atividade fotossintética de uma folha seria controlada pela intensidade das trocas gasosas entre a atmosfera interior da folha e a atmosfera externa. Essas trocas de gases, incluindo o gás carbônico, seriam efetuados através dos estômatos, cujo grau de abertura depende em grande parte do estado de hidratação dos tecidos foliares, que seriam dados através do potencial hídrico foliar. A resistência estomática, que mede o grau de fechamento dos estômatos que regula as trocas gasosas, é diretamente dependente do potencial hídrico foliar e determinante do nível de atividade fotossintética, e portanto de alongamento foliar (Nabinger \& Medeiros., 1995).

$\mathrm{Ng}$ et al. (1975), trabalhando com $P$. maximum var. trichoglume estudaram o efeito de ciclos repetitivos de "déficit" de água nas relações hídricas e no crescimento desta gramínea. Verificaram que quando o conteúdo de água no solo diminui para valores mais negativos do que - $0,1 \mathrm{MPa}$, a resistência estomatal começou a aumentar e concomitantemente a axa de transpiração a diminuir. A redução na taxa de fotossíntese líquida mostrou ser o principal determinante das pequenas taxas de crescimento relativo das plantas estressadas no decurso dos ciclos iniciais de "déficit" em água, mas subsequientemente, tão logo a expansão de área foliar foireduzida , a razão de área foliar passou a ter influência significativa. O estresse por água mostrou influir diretamente no crescimento, e de modo indireto via efeito no desenvolvimento ontogênico das plantas. 
Resultados semelhantes foram obtidos com a mesma gramínea em trabalho de Ludlow $\& \operatorname{Ng}(1976)$.

Barker et al. (1993), estudando os efeitos fisiológicos de potencial osmótico e elasticidade de parede celular em cinco gramíneas forrageiras dentro de condição "déficit hídrico", encontraram que todas as plantas forrageiras promoviam um ajuste osmótico, sendo aparentemente superior para gramíneas $\mathrm{C}_{4}$ em comparação as $\mathrm{C}_{3}$, sendo esta última as que apresentaram maior flexibilidade de parede celular, no qual permitiram manterem-se túrgidas apesar de baixos potenciais de água na folha.

\subsubsection{Luz}

A luz solar pode afetar o desenvolvimento e florescimento das gramíneas, de modo que o seu efeito poderia ser dividido em três diferentes componentes: resposta ao comprimento de radiação recebida (fotoperiodismo), a qualidade de luz (comprimento de ondas), e a irradiação (energia radiante). Este três componentes interagem durante todo o crescimento da planta e principalmente no momento de florescimento.

'tMannetje \& Pritchard (1974) estudaram como a produtividade de gramíneas tropicais e subtropicais tinham o seu crescimento relativo afetado pelas condições de oscilações de temperatura diurna-noturna e pelos fotoperíodos. Foi verificado que o fotoperíodo tem influência direta na produtividade de gramíneas, quando estas cresciam em condição de fotoperíodo de 14 e 11 horas de luz, maior fotoperíodo promoveu maior crescimento relativo; contudo, o efeito da temperatura foi mais significante. $\mathrm{O}$ associação de baixas temperatura e curtos fotoperíodos seria o principal fator climático limitante do crescimento de plantas forrageiras.

Normalmente, em ambientes tropicais e subtropicais, locais onde predomina o Panicum sp., são ambientes caracterizados por elevados índices de radiação (acima de 300 cal. $\mathrm{cm}^{2} \cdot \mathrm{dia}^{1}$ ), o que indicaria que este fator não se constituiria em limitante para o desenvolvimento das plantas (Silva, 1995). De toda radiação que atinge uma pastagem bem manejada, somente uma pequena porcentagem do total de energia luminosa recebida é convertida em energia química, que é armazenada como produto 
fotossintético e novo material vegetal. Em pastagens de clima temperado, a conversão líquida é em torno de $2 \%$, sendo muito maior que a média mundial $(0,5 \%)$ (Whatley \& Whatley, 1982)

Para gramíneas que crescem em ambientes que apresentam períodos de crescimento curtos, quando colocadas em condições climáticas favoráveis, apresentam necessidade de ocupação local rápida. Estas plantas teriam rápido desenvolvimento inicial de suas áreas foliares para obterem alta interceptação de luz, e assim poder apresentar produções significativas de biomassa (Muchow et al., 1990).

Madakadze et al. (1998) estudaram durante 3 anos o desenvolvimento de 9 populações de P. virgatum L. crescendo na região sudoeste do Canadá, que apresentam temperaturas frias até o inicio do verão. As populações apresentaram diferentes índices de área foliar durante o período de crescimento, mostrando-se máximo no início e no meio do verão, quando apresentaram valores entre 6 e $8\left(\mathrm{~m}^{2} \cdot \mathrm{m}^{-2}\right)$, que permitiram uma produção de biomassa no final da estação de crescimento entre 8.4778 e 10.869 kg.ha ${ }^{-1}$, e mostrando a sua possibilidade de produção nesta região.

\subsection{Aspectos morfológicos e fisiológicos das plantas forrageiras.}

Sendo que os herbívoros se alimentam das partes verdes das plantas, a disponibilidade de forragem deve ser entendida como a biomassa aérea viva acumulada durante o processo de crescimento das plantas que compõem as pastagens (Nabinger, 1997). Isso pode ser conseguido através da otimização do balanço entre o crescimento da parte aérea da forragem, perdas devido a senescência dos tecidos e a produção de forragens pela remoção através do ato de pastejo ou de corte (Humphreys, 1991).

\subsubsection{Morfogênese}

A taxa de crescimento de uma pastagem, além da nutrição, depende da estrutura e da fisiologia dos vegetais que a compõem e da interação desses dois fatores com as condições climáticas existentes (Pedreira, 1973). Uma pastagem é formada de 
população de plantas, constituídas de várias hastes, e estas originadas de gemas contidas nos fitômeros da haste primária ou seminal do início de desenvolvimento da planta. $\mathrm{O}$ acúmulo de massa numa haste ocorre devido ao acúmulo de fitômeros e do seu desenvolvimento individual (expansão foliar, alongamento e engrossamento dos nós e entrenós), no qual apresentaria o seu surgimento em termos de tempo térmico constante. Assim, sendo um fitômero a unidade básica de uma haste, que no caso das gramíneas é constituído pelo nó, entre-nó, gemas auxiliares, bainha e lâmina foliar, em uma única planta cada haste seria capaz de formar potencialmente um perfilho ou uma ramificação, cujo número dependerá do potencial genético de cada cultivar (Nabinger, 1997).

Assim, numa pastagem em crescimento vegetativo, na qual aparentemente apenas folhas são produzidas, a morfogênese pode ser descrita por três características básicas: taxa de alongamento das folhas, taxa de surgimento de folhas e duração de vida da folha. Sendo essas características determinadas geneticamente, mas influenciadas por variáveis ambientais. A combinação dessas variáveis morfogêneticas determinam as principais características estruturais das pastagens: tamanho de folha, densidade de perfilho e número de folhas vivas por perfilho (Chapman \& Lemaire $^{2}$ citado por Nabinger (1997)).

\subsubsection{Crescimento de pastagem}

O crescimento das gramíneas é determinado a partir de uma relação de balanço líquido entre o aumento em área foliar, descontando-se a senescência e o tecido aéreo destacado, que estariam disponíveis para uso animal .

O crescimento em área foliar é diretamente limitado pela quantidade de luz interceptada pelas folhas, que com o aumento do índice de área foliar, tem-se o aumento do sistema fotossintético e uma diminuição na taxa de fotoassimilação líquida (fotossíntese bruta menos fotorespiração), que afetam a taxa de crescimento da planta. $\mathrm{O}$ arranjo geométrico da cobertura aérea, seria outro fator que influencia esse crescimento,

${ }^{2}$ CHAPMAN, D.F.; LEMAIRE, G. Morphogenetic and strutural determinants of plant regrowth after defoliation. In: INTERNATIONAL GRASSLANDS CONGRESS, 18, New Zealand , 1993. Proceeding. New Zealand: Massey University, 1993. p.95-104 
onde a inclinação das folhas e a radiação diferenciada recebida nas folhas presentes no interior da planta, estariam influindo no crescimento de área foliar através de mudança na taxa de fotossíntese líquida (Humphreys, 1991)).

A senescência abrangeria todos os processos de deterioração que acompanhariam o envelhecimento e que conduziria a morte de um órgão ou da planta toda. Esse processo poderia ser devido a fatores climáticos (geada ou seca) ou ao mal manejo de pastagem, uma vez que o crescimento da mesma ocorre de modo contínuo, e dentro de condições favoráveis, de modo rápido, permitindo que a biomassa excedida não seja totalmente pastejada pelos animais (Humphreys, 1991).

Wilson \& 'tManetje (1978), estudaram o efeito de condições climática sobre a senescência, digestibilidade e conteúdo de carboidratos em pastagens de Cenchrus ciliares cv. Biloela (capim Buffel) e P. maximum var. trichoglume cv. Petri (green panic) cultivados por 2 anos, em uma região sub-tropical seca de Queensland - Austrália. No estudo realizado nas condições climáticas mais favoráveis ao crescimento das gramíneas (verão), observou-se maior ocorrência de senescência, com depreciação do potencial de valor nutritivo, devido a diminuição na digestibilidade das folhas para próximo de $65 \%$. A rápida senescência na estação de crescimento significou desperdício da forragem produzida, devido em parte pela baixa freqüência de pastejo, que expõe grandes quantidades de folhas senescentes e a diminuição de digestibilidade do dossel. Fatores como excesso de nitrogênio ou períodos de estresses hídricos contribuíram para o aumento da senescência na pastagem. Produções de pastagem no início da primavera foram positivos para digestibilidade e maior demora em tempo para ocorrência de senescência.

A desfolha é a retirada das lâminas foliares das gramíneas de modo mecânico ou por pastejo. A intensidade de desfolha em uma pastagem seria avaliada pelo material foliar residual ou remanescente presente quando os animais são retirados (Humphreys, 1991).

A recuperação das plantas desfolhadas dependeria de dois fatores: teores de carboidratos de reserva e de área foliar remanescente. Dependendo do índice de área foliar (IAF) remanescente, a planta faria uso dos carboidratos de reservas como fonte de 
energia inicial para produção de nova massa foliar, permitindo um aumento na taxa de crescimento relativo e de produção de matéria seca (Vallentine, 1990; Rodrigues \& Reis, 1995).

Preconiza-se que as pastagens devam ser manejadas de forma a permitir pronta recuperação das plantas pastejadas. Embora reconhecendo que a manutenção de um IAF ótimo sob condições de pastejo seja praticamente impossível, é razoável admitir que o crescimento da plantas será reduzido com a manutenção de um IAF baixo, devido à inadequada interceptação de luz pelas plantas. Por outro lado, o acúmulo de matéria seca também será reduzido com a manutenção de valores elevados de IAF em decorrência do aumento na atividade respiratória e da acelerada senescência de folhas (Hodgson (1990).

A freqüência de corte possibilita com que a pastagem apresente uma menor quantidade de folhas senescentes no local de pastoreio (Humphreys, 1991; Carvalho e Damaceno (1996)).

\subsection{Estacionalidade}

A combinação dos fatores climáticos, de planta, de solo e do animal, discutidos anteriormente, fazem com que as pastagens apresentem uma característica de estacionalidade de crescimento. A planta apresenta em determinado momento no ano, seu melhor valor nutritivo, com as gramíneas apresentando sua melhor qualidade e máxima quantidade produzida de matéria seca, disponível para consumo animal. Geralmente esta estacionalidade de crescimento nas gramíneas se relaciona ao ciclo das estações (Vallentine, 1990).

Ghelfi Filho (1972) obteve, em cultivo de capim elefante Napier irrigado, a produção total anual de cerca de $23.000 \mathrm{~kg}$ de $\mathrm{MS} . h a^{1}$, que se distribuiu em $76 \%$ no verão e $24 \%$ no inverno.

Pedreira (1973), estudando o crescimento estacional de vários capins, encontrou que a taxa de crescimento diário nos capins colonião, gordura, jaraguá, e pangola de 
Taiwan durante o inverno, corresponderam em relação ao verão a 13\%, 36\%, $15 \%$ e $13 \%$ respectivamente . A produção de matéria seca corresponderam a cerca 9\%, 16\%, 6\% e $8 \%$ da produção anual dos capins colonião, gordura, jaraguá e pangola de Taiwan.

A pesquisa em buscado selecionar $P$. maximum que não apresentem problemas de estacionalidade, o que tem sido difícil uma vez que as máximas produções na seca são de 14\% em relação à produção anual (Jank, 1995)

O estabelecimento de pastagens com ecotipos superiores para a produção de matéria seca no período seco pode permitir aumentos significativos na lotação das pastagens, mas não resolve os problemas decorrentes da estacionalidade de produção, ou seja, a lotação animal nas pastagens estabelecida pelos níveis mais baixos de produtividade da forragem, a ocorrência de pastejo desuniforme, o aparecimento de áreas super pastejadas que se transformam em focos de degradação e o aparecimento de área sub-pastejadas, ocasionando grandes perdas (Corsi, 1988).

\subsection{Evitando a estacionalidade em pastagens}

A escolha de técnicas que se equacionam à solução do problema decorrente da estacionalidade de produção das plantas forrageiras deve ser coerente com o nível da exploração pecuária, diferindo principalmente pela necessidade de intensificação de uso das pastagens. Assim, a adoção de técnicas de intensificação do processo seria crescente em consequiência do conhecimento técnico e utilização do sistema de produção.

O uso de algumas técnicas de manejo na própria pastagem, podem permitir respostas significativas quanto à tentativa de diminuir problemas com a estacionalidade das pastagens. $\mathrm{O}$ uso de pastejo diferido, de espécies forrageiras resistentes às condições de inverno e a suplementação no período seco com forragens conservadas (feno e/ou silagem), resíduos agro-industriais e de culturas de invernos, já mostrariam bons resultados para alimentação dos animais e diminuiriam as defasagens de produção forrageira ocorridas durante o ano (Rolim, 1994). 
Já o uso de adubação e irrigação como forma de diminuir a estacionalidade, necessitam de maior investimento de capital e de uso em tecnologia.

\subsubsection{Adubação nitrogenada}

Na busca de elevar o número de unidades animais por área, tem-se procurado fazer melhor uso da área disponível para pastagem nas propriedades agrícolas, através do uso de novos sistemas de pastejo que difiram da lotação contínua, que ainda é o mais usado no Brasil. A sofisticação que envolve certos sistemas, como o rotacionado, muitas vezes exigem constante acompanhamento técnico, além de freqüentes decisões de manejo podem requerer maior emprego de capital (Rodrigues \& Reis, 1997) .

Uma das peças chave no manejo de pastagens que tem provocado aumento no rendimento na propriedade e melhora de performance econômica tem sido o uso de fertilizantes nitrogenados. Quando a planta cresce em um ambiente no qual não apresenta fatores limitantes para o seu desenvolvimento (fertilidade de solo ou climáticos), tem-se encontrado resposta à aplicação de fertilizantes nitrogenados (Jarvis, 1998) .

Vicente-Chandler (1973), trabalhando doses de nitrogênio variando de 0 a 1.792 kg N.ha ${ }^{1}$ com P. maximum e outros 6 capins, encontrou que este propicia expressivas respostas à adubação, até o máximo nível estudado. $\mathrm{O}$ colonião mostrou-se mais produtivo que o gordura e o pangola, mas inferior ao capim-elefante em altos níveis.

Addison et al. (1985) estudou o efeito da aplicação de três doses anuais de fertilizante nitrogenado ( 22,5; 45 e $90 \mathrm{~kg} \mathrm{~N} \cdot \mathrm{ha}^{-1}$ ) no período de primavera/verão em um pasto de $P$. maximum cv. Trichoglume (green panic) por quatro anos, que apresentaram ou não corte do material residual para uso como feno. A produção de massa seca da pastagem respondeu linearmente ao aumento na taxa de nitrogênio, sendo que as pastagens que não sofreram cortes apresentaram sempre maiores quantidades de massa seca, independente da dose de nitrogênio usada. A maior dose de nitrogênio permitiu que o green panic apresentasse maior população dentro da pastagem quando comparado as espécies nativas. 
Peake et al. (1990) trabalhando com capim Buffel (Cenchrus ciliares) e Green Panic ( $P$. maximum cv. Trichoglume), também encontraram respostas para a produção de massa seca à aplicação de nitrogênio durante 6 anos de pesquisa.

Estudando o efeito da disponibilidade de forragem e de adubação com $125 \mathrm{~kg}$ N.ha ${ }^{-1}$ conduzidos durante dois períodos de seca e de chuva, Alvim et al., (1992) avaliaram a produção de leite de vacas mantidas em pastagem de capim-angola (Brachiaria mutica (Forsk) Stapf). O uso do adubo nitrogenado aplicado durante o período das águas em pastagem de capim-angola, e manejada para uma disponibilidade de forragem ao redor de $1.700 \mathrm{~kg}$ de ${\mathrm{MS} . h a^{-1}}$, fez melhorar a qualidade da forragem e a lotação animal no período seco, resultando em produções ao redor de 8,0 a 8,5 kg de leite por vaca por dia, ou de 14,5 a $16,5 \mathrm{~kg}$ de leite por hectare dia. O não uso de adubação para esta mesma disponibilidade de forragem, resultou em menores produções de leite.

$\mathrm{O}$ uso de leguminosas em consorciação com $P$. maximum permitiu produções em massa seca equivalentes a níveis de adubação com fertilizantes nitrogenados, variando entre 40 a $93 \mathrm{kgN} \cdot \mathrm{ha}^{-1}$. O valor protéico do colonião consorciado mostrou-se superior, entre 1 a 2\%, à aqueles adubados com fertilizantes químicos (Mattos \& Werner, 1979).

A eficiência de uso do adubo nitrogenado pode depender da umidade do solo. Plantas de $P$. maximum cv. Tobiatã cultivadas em presença de estresse hídrico apresentaram menor eficiência de uso do nitrogênio, como também do fósforo e potássio aplicados (Dias Filho et al., 1992).

Essa melhor eficiência de uso do adubo pode estar relacionada a diferença entre os cultivares quanto a diferença de eficiência de uso da água no solo, como relatado por Pieterse et al. 1997, estudando quatro cultivares de P. maximum, comparando diferentes níveis de nitrogênio.

Trabalhando com capim-colonião, Werner (1970/71) estudou épocas de adubação nitrogenada na busca de maior suprimento de forragem para a época seca do ano. Empregou nitrocálcio para fornecer nitrogênio na dose $100 \mathrm{KgN}_{\mathrm{hah}}{ }^{-1}$.ano ${ }^{-1}$, testando noves épocas de aplicação. Com base em resultados de três anos foram observadas diferenças significativas na produção anual de massa seca, entre as áreas adubadas e as 
não adubadas com nitrogênio, enquanto que não se encontrou variações significativas quanto às épocas de adubação. Quando foi considerada a proporção da produção de massa seca no período "das secas" em relação ao total anual, obteve-se produção de massa seca de 21,0\% para a adubação feita em março de cada ano, em contraposição aos 7,6 e 9,0\% verificados para as adubações de novembro e janeiro, respectivamente.

O uso de adubação nitrogenada no final do período de chuvas foi estudado por Dias et al. (1998) em três gramíneas tropicais buscando determinar a sua produtividade e a qualidade como plantas forrageiras. A adubação nitrogenada, com doses variando entre 0 a $400 \mathrm{kgN} \cdot \mathrm{ha}^{-1}$, proporcionou aumento de produtividade (rendimento de massa seca) e de qualidade (proteína bruta e fibras), sendo que a dose de $100 \mathrm{~kg} \mathrm{N.ha^{-1 }}$ proporcionou maior eficiência de utilização e taxa de recuperação aparente do nitrogênio aplicado. O capim coast-cross (Cynodon dactylon L. Pers. cv. Coastal x Cynodon nlemfuensis var. robustus) mostrou-se superior às demais gramíneas testadas.

O uso da adubação nitrogenada, estimulando o crescimento das plantas, pode elevar os níveis de perdas se não forem usadas máquinas eficientes para colheita e armazenamento da forragem, ou o uso de elevação de carga animal para pastejo. A produção intensiva de forragem ainda pode provocar na planta níveis de exigências em nutrientes mais elevados, no tempo e em quantidade, devido às maiores exportações de nutrientes das áreas de pastagens, através do produto animal (Corsi, 1994).

\subsection{Uso da Irrigação em pastagens}

A água é um dos mais importantes elementos do meio ambiente para a produção de forragem. A quantidade total e principalmente a distribuição estacional de chuvas são fatores do meio ambiente que regulam a adaptação de plantas a uma região e, consequentemente, regem a sua produção, além da temperatura e energia radiante (Sprague\&Mclould citado por Rolim, 1994).

A justificativa para a alocação de água para uso na irrigação de pastagens, estaria baseada no maior retorno líquido de produção animal em relação a outros manejos, a possibilidade de uso de menor área produtiva com a possibilidade de uso de água de 
menor qualidade e a promoção de um efetivo período de crescimento durante as estações mais secas do ano. $\mathrm{Na}$ Austrália, a área de pastagem irrigada representa aproximadamente $55 \%$ da área total usada para irrigação, representando aproximadamente 1 milhão de hectares (Dovrat et al., 1993).

$\mathrm{O}$ uso da irrigação tem sido tentado como elemento regulador da produção e como instrumento para diminuir o efeito da estacionalidade nas pastagens. Resposta quanto ao uso da irrigação para modificação da produção de massa seca, parece estar mais ligado às condições climáticas presentes no momento do experimento e frequiência de irrigação, do que relacionados as características das espécies de gramíneas usadas.

Um fator que foi considerado inicialmente nos trabalhos de pesquisa era que ao se solucionar o problema de "déficit" hídrico presente no período das secas, o problema de estacionalidade das plantas forrageiras estaria se resolvendo. Ghelfi Filho (1972) estudando três níveis de irrigação $(25 \%, 50 \%$ e $75 \%$ da capacidade de campo) comparando as condições de umidade do período, observou que os níveis de irrigação proporcionaram aumento de produção do capim-Elefante (Pennisetum purpureum, Schum. ) no período seco em $26 \%$, quando comparado a testemunha, o que não alterou o efeito estacional das gramíneas. O uso de irrigação proporcionou aumento na produção total anual máximo de 26\%. Resultados semelhantes foram obtidos pelo mesmo autor em 1976, em trabalho com o capim Colonião.

A irrigação sozinha, também não influenciou o desenvolvimento de dois cultivares de capim-elefante (P. purpureum) (Carvalho et al. , 1975) e de diferentes gramíneas de climas tropical e temperadal testadas no Centro Nacional de Pesquisa de Gado de Leite (Alvim et al., 1986).

Herrera et al. (1985) em experimento realizado em Cuba, com três espécies forrageiras (Cynodom dactylon, P. maximum e Cenchrus ciliares ), usando como aplicação para irrigação 90, 80 e 70\% da capacidade de campo, durante dois anos verificaram que a interação irrigação e gramíneas não apresentou nenhuma resposta durante os 13 cortes realizados. Valores de aumento na produção, ficaram próximos aos já comentados anteriormente (37\%). Para os autores, os principais fatores responsáveis 
pelas baixas produções seriam os fatores climáticos, possivelmente a temperatura e luz (Dovrat et al., 1993).

O uso da irrigação foi testado na integração de pastagens de setária (Setaria sphacelata (Schum.) Moss) irrigada e de azevém (Lolium multiflorum Lam.) durante o período seco, avaliando a produção de leite (Alvim et al., 1993). A setária somente começou a responder à irrigação a partir de meados de agosto, quando os demais fatores climáticos reguladores de crescimento das plantas tropicais, temperatura e luminosidade, atingiram índices favoráveis. A qualidade da pastagem de setária melhorou, e proporcionou aumento da produção de leite para valores médios entre 8,5 a 9,0 kg de leite.vaca ${ }^{-1} \cdot \mathrm{dia}^{-1}$. A lotação foi de aproximadamente de 2,5 vacas.ha ${ }^{-1}$ para uma

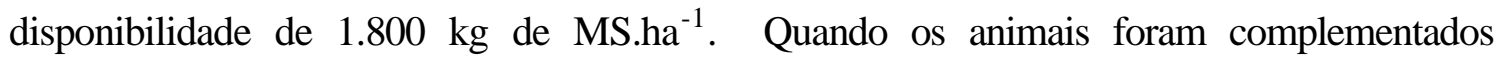
com pastagens de azevém anual, elevou-se a produção de leite para valores próximos a $12 \mathrm{~kg}$ leite.vaca ${ }^{-1} \cdot \mathrm{dia}^{-1}$.

Respostas contrárias ao uso da irrigação podem ocorrer, como as que Pérez \& Acosta, (1986) encontraram ao estudar diferentes frequiências de irrigação em Coastcross-1 , grama-estrela, capim-Colonião e Likoni-guinea. Aumentos de 50 a 100\% na produção de massa seca foram obtidos quando a frequiência de irrigação aumentou, passando de 4,37 t MS.ha- ${ }^{-1}$ para valores próximos a 9,14 t MS.ha' ${ }^{-1}$.

\subsubsection{Uso de adubação nitrogenada e irrigação em pastagens}

A técnica de irrigação em pastagens durante o "inverno" no Brasil Central, associada à adubação, em trabalhos experimentais, tem mostrado aumento na produção entre 20 a $70 \%$ em relação à testemunha no período de 150 dias; sendo que estes aumentos não seriam suficientes para equilibrar as produções de "verão" e "inverno" (Corsi, 1978 citado por Rolim, 1994).

A resposta à associação adubação nitrogenada e irrigação tem sido encontrada, tanto no período da seca como no período das chuvas, quando esta visa evitar períodos de "déficit" hídrico para a planta no verão. 
Estudando a produção dos capins, gordura (Melinis minutiflora Pal. de Beauv.), sempre verde (Panicum maximum) e pangola (Digitaria decumbens Stent), no município de Viçosa (M.G.), Ladeira et al. (1966) encontraram que quando se fez uso de adubação nitrogenada (45 kg N.ha ${ }^{-1}$ ) e de irrigação conjuntamente no período seco, as produções de massa verde foram $84 \%$ superiores a testemunhas. Resultados semelhantes foram obtidos por Ararat \& Tafur (1990).

Em outro estudo com Panicum. maximum e Panicum. purpurascens Raddi, Vasquez (1965) encontrou interação significativa com o uso de nitrogênio e irrigação no aumento da produção das duas plantas forrageiras, sendo encontrados maiores resultados quando utilizou 448,73 kg N.ha ${ }^{-1} \cdot \mathrm{ano}^{-1}$. As produções das plantas forrageiras no período seco se eqüivaleram a $5.549,15 \mathrm{~kg}$ matéria seca.ha ${ }^{-1}$. O nitrogênio aumentou o conteúdo de proteína na forragem, sendo que este foi menor com o uso de irrigação. O significado prático para isto seria que ao se usar irrigação, as forrageiras devem ser adubadas com nitrogênio para que consigam manter a sua qualidade protéica. Aumentos acumulados nos teores acumulados de nitrogênio no tecido de $P$. maximum $c v$. Thrichoglume $e$ Cenchrus ciliares L. com o uso irrigação, foram também encontrados por Cameron et al. (1990).

Aumentos de produções de plantas forrageiras no período úmido, estudando interação com o uso de nitrogênio e irrigação, foram comentados por Quinlan et al., 1981; Bruyn \& Kingston ,1997; Donaghy et al., 1997 e Wales et al., 1998. 


\section{MATERIAL E MÉTODOS}

\subsection{Preparo e Condução do Experimento}

O experimento foi conduzido em área localizada na Fazenda Areão, pertencente à Escola Superior de Agricultura "Luiz de Queiroz", em solo Terra Roxa Estruturada eutrófica, A moderado textura argilosa (Anexo 1), solos profundos e permeáveis, e apresentando textura argilosa em todo perfil, com um incremento de argila no horizonte B e declividade média de 4\%. O experimento foi conduzido por período de 1 ano, sendo efetuados 9 cortes da forragem.

Inicialmente, análises física e química do solo foram realizadas em 3 profundidades : 0-20; 20-40 e 40-60 cm, sendo determinandos:

- Densidade e granulomentria do solo;

- Análise de fertilidade do solo, para cálculo da calagem e adubação corretiva com fósforo e potássio.

Repetiram-se as análises semestralmente para acompanhamento da extração de nutrientes do solo, visando a reposição de fósforo e potássio via adubação de manutenção nas parcelas. As análises laboratoriais encontram-se discutidas posteriormente no texto.

A gramínea utilizada foi o capim-Tanzânia (Panicum maximum Jacq. cv. Tanzânia). A área foi preparada mecanicamente em fevereiro de 2000 e semeada no início de março, com posterior vedação por 6 meses para a possibilitar a formação da pastagem. O preparo do solo baseou-se em uma aração e gradagem em número suficientes para adequado destorroamento superficial do solo. 
A adubação nitrogenada para a formação da pastagem fi feita em cobertura, 30 dias após a germinação, com $40 \mathrm{~kg} \mathrm{~N} \cdot \mathrm{ha}^{-1}$ na forma de Uréia via fertirrigação por Pivô Central. Fez-se a aplicação, fracionando o total do adubo em duas aplicações espaçadas de 7 dias, usando lâmina de irrigação de $3 \mathrm{~mm}$ (100\% do percentímetro). Outra adubação nitrogenada foi feita após três meses, após o primeiro pastejo, visando diminuir a competição entre plantas e eliminar a maior parte das gemas apicais (favorecendo maior perfilhamento) através do pastejo com alta lotação animal por curto espaço de tempo, utilizou-se a dosagem de $20 \mathrm{~kg} \mathrm{~N} \cdot \mathrm{ha}^{-1}$ na forma de Uréia, também via fertirrigação por Pivô Central.

A instalação do sistema de irrigação só pode ser iniciada a partir de setembro de 2000, devido ao atraso na entrega dos equipamentos necessários ao projeto.

No inicio do experimento, foram colocados animais para pastejo, de maneira que a área apresentasse uma altura média de resíduo de $0,20 \mathrm{~m}$ do solo.

O corte da forragem, foi efetuado através de uma roçadeira motorizada, a intervalos de 36 dias, tanto no período Úmido, (Novembro - Março), como nos períodos Secos (Abril - Setembro). Após o corte, as sub-parcelas recebiam as adubações com nitrogênio nas dosagens pré-determinadas, via fertirrigação com nitrato de amônio, sendo as dosagens anuais divididas em função do número de cortes. Os dois primeiros períodos de coleta receberam adubação com uréia, onde considerou-se uma perda estimada de $20 \%$ do produto por volatilização.

\subsection{Manejo e condução da Irrigação}

O monitoramento do potencial de água no solo foi realizado através de tensiômetro digital, onde as lâminas de irrigação nas parcelas foram constituídas de uma fração da parcela de referência mantida na capacidade de campo (padrão). As lâminas de água aplicadas nessas parcelas foram de 0,30 e $70 \%$ da lâmina de água a ser resposta no padrão $(100 \%)$, e $50 \%$ a mais da lâmina necessária ao padrão (150\%),totalizando 5 lâminas de irrigação no experimento. 
O controle da umidade na parcela padrão, foi efetuado através de 4 baterias de 6 tensiômetros a 10, 20, 40, 60, 80 e $100 \mathrm{~cm}$ de profundidade, com leitura feita diariamente, sempre no mesmo horário.

A freqüência de irrigação e a quantidade de água aplicada foram determinadas em função da variação do potencial mátrico acusado pelos tensiômetros. A irrigação iniciou-se quando a média dos tensiômetros posicionados a $20 \mathrm{~cm}$ registraram $-0,20$ bar. As curvas de retenção de água do solo, foram obtidas em laboratório, com amostras de solos indeformadas, utilizando-se mesa de retenção e placa porosa, coletadas em três profundidades ( $020 ; 20-40$ e $40-60 \mathrm{~cm})$. Através do potencial mátrico $\left(\psi_{\mathrm{s}}\right)$ dado pelo tensiômetro e da equação de van Genuchthen (1980), determinou-se a umidade no solo:

$$
\boldsymbol{\theta}=\boldsymbol{\theta}_{p m p}+\frac{\boldsymbol{\theta}_{s}-\boldsymbol{\theta}_{p m p}}{\left[1+\left(\boldsymbol{\alpha} \times\left|\Psi_{s}\right|\right)^{n}\right]^{n}}
$$

Onde:

- $\quad \theta_{\mathrm{s}}-$ conteúdo de água volumétrico $\left(\mathrm{cm}^{3} \mathrm{~cm}^{-3}\right)$ no solo;

- $\quad \theta_{\mathrm{s}}-$ conteúdo de água volumétrico $\left(\mathrm{cm}^{3} \mathrm{~cm}^{-3}\right)$ no solo saturado;

- $\theta_{\mathrm{pmp}}$ - conteúdo de água volumétrico $\left(\mathrm{cm}^{3} \mathrm{~cm}^{-3}\right)$ no solo no ponto de murcha permanente;

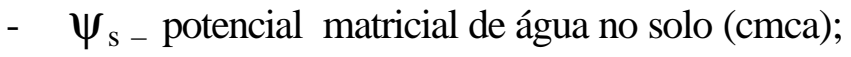

- $\quad \alpha$ - fator escalar para o $\psi_{\mathrm{s}}(1 / \mathrm{cm})$

- m e n - parâmetros de ajuste de equação.

Para repor a água perdida nas parcelas experimentais, utilizou-se a irrigação por gotejamento, com emissores autocompensantes distanciados em $50 \mathrm{~cm}$ na linha irrigada e $70 \mathrm{~cm}$ entre linhas, distribuídos sobre a superfície do solo. Cada gotejador apresentou uma vazão 1,6 1.hora ${ }^{-1}$, sendo as linhas posicionadas dentro das sub-parcelas.

Simultaneamente ao monitoramento da umidade do solo via tensiometria, foram coletados dados meteorológicos diários (temperatura de bulbo úmido e seco, umidade 
relativa do ar , precipitação e unidade fototérmica) a partir de uma estação meteorológica automática instalada dentro da área experimental.

\subsection{Delineamento Experimental}

O experimento foi conduzido pelo período de 1 ano, sendo que após cada época de corte da forragem, feita a $20 \mathrm{~cm}$ de altura da superfície do solo, e levando em consideração os diferentes períodos de crescimento da planta forrageira, fez-se análise de variância dentro do modelo de parcela sub-sub-dividida, dividido em três épocas climáticos (verão, inverno e primavera) constituído de 3 coletas (Quadro 1).

Quadro 1. Modelo de análise de variancia usada na análise experimental com capim-Tanzânia

\begin{tabular}{|cc|}
\hline Causas de variação & Graus de Liberdade \\
\hline Bloco & 2 \\
Lâmina & 4 \\
RESÍDUO (A) & 8 \\
\hline PARCELAS & 14 \\
\hline Dose N & 4 \\
Lam x Dos & 16 \\
RESÍDUO (B) & 40 \\
\hline SUBPARCELAS & 74 \\
\hline Épocas & 2 \\
Lam x Epo & 8 \\
Dos x Epo & 8 \\
Lam x Dos x Epo & 32 \\
RESÍDUO (C) & 100 \\
\hline TOTAL & 224 \\
\hline
\end{tabular}

Nas parcelas foram distribuídas as diferentes laminas de irrigação, e nas subparcelas as doses de nitrogênio $\left(0,100,275,756\right.$ e $2079 \mathrm{~kg} \mathrm{~N} . \mathrm{ha}^{-1}$.ano ${ }^{-1}$ divididas em 
nove aplicações) na forma de nitrato de amônio. As áreas das parcelas e sub-parcelas foram de $105 \mathrm{~m}^{2}$ e $15 \mathrm{~m}^{2}$ respectivamente.

As datas de coletas experimentais dentro de cada período climático foram:

- Verão: 1 - 21/11/2000 a 26/12/2000

2 - 02/01/2001 a 06/02/2001

$3-14 / 02 / 2001$ a $21 / 03 / 2001$

- Inverno: 4 - 30/03/2001 a 04/05/2001

$5-11 / 05 / 2001$ a $15 / 06 / 2001$

$6-20 / 06 / 2001$ a $25 / 07 / 2001$

- Primavera: 7 - 27/07/2001 a 31/08/2001

$8-03 / 09 / 2001$ a $08 / 10 / 2001$

$9-10 / 10 / 2001$ a $14 / 11 / 2001$

Foram feitos estudos de regressão ao longo do ano.

Sabendo que a produção de forragem de uma planta depende em muito dos fatores a avaliar, usou-se o modelo de polinômio de segundo grau, para representar o comportamento das variáveis lâmina de irrigação e doses de nitrogênio. Com os resultados das regressões, foram feitas considerações econômicas sobre o uso de irrigação e de doses de nitrogênio, através da determinação da lâmina de irrigação e da dose de nitrogênio ótima economicamente.

O nível de significância trabalhado nas análises de variância e nas regressões foram ao nível de $10 \%$ e para o teste de média a 5\%, sendo usado para as análise de variâncias e regressões o pacote estatístico SANEST e para os testes de médias e homocedacidades o SAS. 


\subsection{Variáveis a serem avaliadas}

\subsubsection{Produção de Forragem}

Antes do corte das subparcelas, que representam a área útil de $2 \mathrm{~m}^{2}$, foram feitos os cortes da forragem, a $20 \mathrm{~cm}$ do solo, usando-se roçadeira motorizada, conforme a recomendação de Garcia (1993). Após o corte, a forragem foi pesada no campo, com o objetivo de se determinar a massa verde ou fresca. Desse material fresco, previamente muito bem uniformizado, foram retiradas amostras representativas de cada subparcela (aproximadamente $1 \mathrm{~kg}$ de material verde) que foram previamente misturadas e uniformizadas no campo, identificadas e colocadas em saco de papel para procedimento de pré-secagem em estufa, com circulação forçada de ar à $65^{\circ} \mathrm{C}$, por 72 horas, até peso seco constante. Os materiais pesados em balança semi-analítica foram moídos em moinho tipo Wiley, passados em peneira de $1 \mathrm{~mm}$ de diâmetro e acondicionados em recipientes de vidro. A secagem definitiva foi obtida tomando-se sub-amostras de cinco gramas do material pré-seco e transferindo-as para estufa a 105 ${ }^{\circ} \mathrm{C}$, por 24 horas, e procedendo-se a pesagem final após uma hora (Garcia, 1993). A quantidade de massa seca foi determinada através da fórmula:

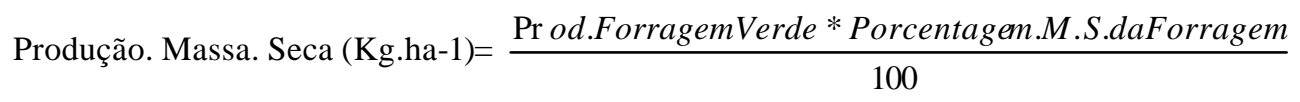

\subsubsection{Determinação de Índices de Eficiências}

\subsubsection{Eficiência de uso da água (EUA)}

O uso eficiente da água foi determinado pela divisão da massa seca, produzida em um período de crescimento, pela quantidade de água aplicada durante esse mesmo período, seguindo orientação de Pieterse et al. (1997) . O denominador da equação abaixo representa a lâmina total de água aplicada em cada período de crescimento. 
$\mathrm{EUA}=\frac{Y}{V+T+E+D}=\mathbf{k g} \mathbf{M S} \cdot \mathbf{m m}^{-1}$

em que :

$\mathrm{Y}$ - produção de fitomassa $\left(\mathrm{kg} \cdot \mathrm{ha}^{-1}\right)$;

$\mathrm{V}$ - água para o crescimento, $\mathrm{mm}$;

T - água para transpiração , mm;

E - água evaporada da superfície do solo, mm;

D - água perdida por drenagem, mm.

\subsubsection{2 Índice de Produção de Fitomassa (IPB)}

Esse índice foi calculado conforme a metodologia de Garabet et al. (1998) , onde a produção de fitomassa, em cada período de corte, foi dividida pela produção total no período de crescimento, usando-se a relação :

$$
\mathrm{IPB}=\frac{\operatorname{Pr} \text { oduçãodeFitomassa }(\text { no.corte })(\mathrm{kg} / \mathrm{ha}) * 100}{\operatorname{Pr} \text { oduçãodeFitomassa }(\text { Período.ou.Ano })(\mathrm{kg} / \mathrm{ha})}=\%
$$

\subsubsection{Eficiência de uso do nitrogênio (EUN)}

$E U N=\frac{Y_{t}-Y_{0}}{N_{t}}=\mathbf{k g}$ de aumento na MS. $\mathbf{k g ~ N}$ aplicado $^{-1}$

$Y_{t}$ - Produção(kg.ha- $\left.{ }^{-1}\right)$ de MS no tratamento " $t$ ";

$\mathrm{Y}_{0}$ - Produção(kg.ha $\left.{ }^{-1}\right)$ de MS no tratamento testemunha;

$\mathrm{N}_{\mathrm{t}}$ - quantidade de $\mathrm{N}\left(\mathrm{kg}_{\mathrm{g}} \mathrm{ha}^{-1}\right)$ aplicado no tratamento " $\mathrm{t}$ ". 


\subsubsection{Eficiência Fisiológica do $\mathbf{N}$ absorvido (EFNabs)}

EFNabs $=\frac{Y_{t}-Y_{0}}{N_{t}-N_{0}}=\mathbf{k g}$ MS aumentada. $\mathbf{k g}$ fertilizante $\mathrm{N}$ oferecido ${ }^{-1}$;

$\mathrm{N}_{0}$ - quantidade de $\mathrm{N}\left(\mathrm{kg} \cdot \mathrm{ha}^{-1}\right)$ aplicado no tratamento testemunha.

\subsubsection{Nitrogênio aparentemente recuperado (NapRec)}

$N a p \operatorname{Rec}=\frac{P^{u t}-P^{u 0}}{N_{t}-N_{0}}=\mathbf{k g} \mathbf{N}$ obtido. $k g \mathbf{N}$ aplicado $^{-1}$

$\mathrm{P}^{\mathrm{ut}}$ - total absorvido de $\mathrm{N}\left(\mathrm{kg} \mathrm{N} \cdot \mathrm{ha}^{-1}\right)$ no tratamento " $\mathrm{t}$ ";

$\mathrm{P}^{\mathrm{u} 0}$ - total absorvido de $\mathrm{N}\left(\mathrm{kg} \mathrm{N} \cdot \mathrm{ha}^{-1}\right)$ no tratamento "testemunha";

$\mathrm{N}_{\mathrm{t}}$ - quantidade de $\mathrm{N}\left(\mathrm{kg}_{\mathrm{g}} \mathrm{ha}^{-1}\right)$ aplicado no tratamento " $\mathrm{t}$ ";

$\mathrm{N}_{0}$ - quantidade de $\mathrm{N}\left(\mathrm{kg} \cdot \mathrm{ha}^{-1}\right)$ aplicado no tratamento testemunha.

\subsubsection{Análise Bromatológica}

Amostras compostas por cada uma das interações dos tratamentos lâmina de irrigação e dosagem de nitrogênio, constituídas pela mistura do material resultante de três blocos experimentais, dentro de cada período de amostragem (9 períodos), foram colocadas para secar a $60^{\circ} \mathrm{C}$, em estufa de circulação forçada de ar, por um período de 
72 horas. O material foi moído em moinho tipo Wiley, em peneira de $1 \mathrm{~mm}$ de diâmetro e acondicionado em recipientes de vidro para análise química, segundo AOAC (1995), determinando-se os teores de proteína bruta por macro Kjeddahl. A fibra insolúvel em detergente neutro (FDN), fibra insolúvel em detergente ácido (FDA) e o teor de lignina, foram determinados segundo método proposta por Goering \& Van Soest (1970). A digestibilidade verdadeira in vitro da matéria orgânica da forragem foi obtida de acordo com o procedimento apresentado por Tilley \& Terry (1963), adaptado por Goering \& Van Soest (1970). 


\section{RESULTADOS E DISCUSSÃO}

\subsection{Variação estatística na produção de massa seca}

Os resultados da análise da variância nas três estações estudadas e sua análise conjunta, encontram-se resumidos nas Tabelas de 1 a 4.

A busca da divisão em três períodos de estudo, visou caracterizar três períodos climáticos distintos, os quais influem de maneira significativa no crescimento do capimTanzânia. A influência de variação de temperatura e fotoperíodo no desenvolvimento do capim-Tanzânia no tempo, usando dados coletados deste experimento, foram usados por Pinheiro (2002) para o estudo de viabilidade econômica do uso da irrigação em pastagens no Brasil.

A divisão da massa seca total, em folha e hastes, teve como objetivo identificar a contribuição de cada uma destas estruturas de tecido, na produção de massa seca total do capim Tanzânia.

A influência dos fatores estudados (lâmina e dose de nitrogênio) pode contribuir com mudança na relação folha/haste, a qual afeta diretamente o grau de aceite da pastagem pelos animais. $\mathrm{O}$ aumento da rejeição do material oferecido aos animais é função da quantidade de hastes presentes na mateira seca total, uma vez que estas apresentam menor digestibilidade em relação as folhas. Pinto et al. (1994) discutiram a importância da relação folha/haste, para tomada de decisão no manejo de gramíneas tropicais e em sua qualidade.

Observa-se que pelos resultados da análise de variância, que dentro das três estações estudadas, a massa seca total apresentou efeito significativo $(\alpha=0.05$ para verão-inverno e $\alpha=0.10$ para primavera) em sua interação tripla de lâmina, dose de 
nitrogênio e período de coleta. O mesmo ocorreu com a massa seca foliar na estação do verão (Tabelas 1, 2 e 3). Já para a massa seca foliar e haste nas demais estações, a interação tripla não foi encontrada. Dentre os possíveis fatores envolvidos pode-se descrever o aumento da variância dos dados, em função da separação das diferentes partes da planta, principalmente para as hastes, e também o menor efeito das lâminas de irrigação na produção de massa seca em algumas estações, que devido a efeitos climáticos, influenciaram na eficiência de uso da água e disponível as plantas.

$\mathrm{O}$ análise dos resultados experimentais, na forma de um delineamento de parcela sub-sub-divididada, deve-se a necessidade de comparar no tempo as variações climáticas que estão afetando tanto o crescimento, como características de dinâmica de tecido e florescimento, e por fim a produção de massa seca do capim Tanzânia.

O modelo estatístico experimental explicou fortemente as variações de produção encontradas, levando a optar-se sempre por trabalhar com dados não transformados, uma vez que as análises transformadas apresentavam semelhança no seu desmembramento com as não transformadas, e também por facilitar o entendimento das unidades analisadas apresentadas no trabalho experimental.

Buscando-se somente observar o efeito da interação entre os períodos climáticos de crescimentos (Verão, Primavera e Inverno), montou-se uma análise de variância (Tabela 4) no qual os valores de cada bloco representavam a média dos efeitos de lâminas de irrigação e dose de nitrogênio dada em cada coleta ( 1 a 9). Assim, as equações de regressões geradas para efeito de lâminas de irrigação e dose de nitrogênio para cada período climático, não podem ser usadas de modo generalizados para representar esta região, uma vez que o ano agrícola de 2002 apresentou uma diferenciação pluviométrica em relação a média regional de 92 anos de dados climáticos para Piracicaba-SP . 
Tabela 1. Análise da variância da massa seca total, folha e haste em capim Tanzânia, na estação do Verão (21/11/2001 a 21/02/2002), em Piracicaba, SP.

\begin{tabular}{|c|c|c|c|c|c|c|c|}
\hline \multirow[b]{3}{*}{ Causas de Variação } & \multirow[b]{3}{*}{ G.L. } & \multicolumn{6}{|c|}{ Massa Seca (kg MS.Ha ${ }^{-1}$.Período ou Coleta ${ }^{-1}$ ) } \\
\hline & & \multicolumn{2}{|c|}{ TOTAL } & \multicolumn{2}{|c|}{ FOLHA } & \multicolumn{2}{|c|}{ HASTE } \\
\hline & & Q.M. & $\mathrm{F}$ & Q.M. & $\mathrm{F}$ & Q.M. & $\mathrm{F}$ \\
\hline Bloco & 2 & $1.911 .225,06$ & - & - & - & $775.741,20$ & - \\
\hline Lamina & 4 & $4.841 .625,21$ & $6,51^{\mathrm{NS}}$ & $1.370 .941,57$ & $3,74^{*}$ & $875.273,70$ & $6,64^{*}$ \\
\hline RESIDUO (A) & 8 & $743.655,77$ & - & $366.318,03$ & - & $131.744,81$ & - \\
\hline PARCELAS & 14 & - & - & - & - & - & - \\
\hline Dose N & 4 & $30.079 .920,89$ & $24,36^{* * * *}$ & $15.846 .897,66$ & $24,60^{* * *}$ & $2.223 .848,53$ & $11,57^{* * *}$ \\
\hline Lam*Dos & 16 & $2.688 .007,11$ & $2,17^{*}$ & $1.797 .090,44$ & $2,78^{*}$ & $181.831,16$ & $0,94^{\mathrm{NS}}$ \\
\hline RESIDUO (B) & 40 & $1.234 .559,65$ & - & $643.103,75$ & - & $192.082,18$ & - \\
\hline SUBPARCELAS & 74 & - & - & - & - & - & - \\
\hline Coleta & 2 & $77.724 .298,45$ & $90,02^{* * *}$ & $66.168 .770,06$ & $117,39^{* * *}$ & $951.922,34$ & $9,80^{* *}$ \\
\hline Lam*Col & 8 & $2.772 .989,79$ & $3,21^{*}$ & $1.338 .949,06$ & $2,37^{*}$ & $265.607,50$ & $2,73^{*}$ \\
\hline Dos*Col & 8 & $5.973 .894,24$ & $6,91^{* * *}$ & $3.518 .309,54$ & $6,24^{* * * *}$ & $486.184,76$ & $5,00^{* *}$ \\
\hline Lam*Dos*Col & 32 & $1.521 .927,24$ & $1,76^{*}$ & $1.136 .295,30$ & $2,02^{* *}$ & $99.722,34$ & $1,02^{\mathrm{NS}}$ \\
\hline RESIDUO (C) & 100 & $863.446,09$ & - & $563.626,59$ & - & $97.109,81$ & - \\
\hline TOTAL & 224 & - & - & - & - & - & - \\
\hline
\end{tabular}

Tabela 2. Análise da variância da massa seca total, folha e haste em capim Tanzânia, na estação do Inverno (22/02 a 26/07/2002) em Piracicaba, SP.

\begin{tabular}{|c|c|c|c|c|c|c|c|}
\hline \multirow[b]{3}{*}{ Causas de Variação } & \multirow[b]{3}{*}{ G.L. } & \multicolumn{6}{|c|}{ Massa Seca (kg MS.Ha ${ }^{-1}$.Período ou Coleta $\left.{ }^{-1}\right)$} \\
\hline & & \multicolumn{2}{|c|}{ TOTAL } & \multicolumn{2}{|c|}{ FOLHA } & \multicolumn{2}{|c|}{ HASTE } \\
\hline & & Q.M. & $\mathrm{F}$ & Q.M. & $\mathrm{F}$ & Q.M. & $\mathrm{F}$ \\
\hline Bloco & 2 & $221.418,96$ & - & $71.064,06$ & - & $457.156,37$ & - \\
\hline Lamina & 4 & $422.160,08$ & $3,80^{*}$ & $106.965,46$ & $4,46^{*}$ & $138.114,69$ & $1,59^{\mathrm{NS}}$ \\
\hline RESIDUO (A) & 8 & $110.840,83$ & - & $23.970,66$ & - & $86.544,66$ & - \\
\hline PARCELAS & 14 & - & - & - & - & - & - \\
\hline Dose $\mathrm{N}$ & 4 & $6.190 .722,480$ & $47,21^{* * *}$ & $1.399 .269,94$ & $21,55^{* * *}$ & $2.044 .477,93$ & $29,82^{* * *}$ \\
\hline Lam*Dos & 16 & $238.087,41$ & $1,81^{*}$ & $63.100,24$ & $0,97^{\mathrm{NS}}$ & $76.753,85$ & $1,11^{\mathrm{NS}}$ \\
\hline RESIDUO (B) & 40 & $131.120,76$ & - & $64.901,44$ & - & $68.553,17$ & - \\
\hline SUBPARCELAS & 74 & - & - & - & - & - & - \\
\hline Coleta & 2 & $41.691 .323,29$ & $427,42^{* * *}$ & $5.648 .539,83$ & $128,66^{* * *}$ & $17.032 .218,95$ & $248,86^{* * *}$ \\
\hline $\mathrm{Lam} * \mathrm{Col}$ & 8 & $390.031,26$ & $3,99^{* *}$ & $119.528,90$ & $2,72^{* *}$ & $138.070,25$ & $2,01^{*}$ \\
\hline Dos*Col & 8 & $1.207 .088,43$ & $12,37^{* * *}$ & $88.669,99$ & $2,01^{*}$ & $1.023 .464,22$ & $14,95^{* * *}$ \\
\hline Lam*Dos*Col & 32 & $143.294,18$ & $1,46^{*}$ & $39.513,76$ & $0,9^{\mathrm{NS}}$ & $61.297,64$ & $0,89^{\mathrm{NS}}$ \\
\hline RESIDUO (C) & 100 & $97.541,01$ & - & $43.902,04$ & - & $68.438,28$ & - \\
\hline TOTAL & 224 & - & - & - & - & - & - \\
\hline
\end{tabular}


Tabela 3. Análise da variância da massa seca total, folha e haste em capim Tanzânia, na estação da Primavera (27/07 a 14/11/2002) em Piracicaba, SP.

\begin{tabular}{|c|c|c|c|c|c|c|c|}
\hline \multirow[b]{3}{*}{ Causas de Variação } & \multirow[b]{3}{*}{ G.L. } & \multicolumn{6}{|c|}{ 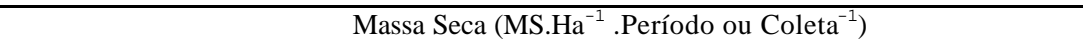 } \\
\hline & & \multicolumn{2}{|c|}{ TOTAL } & \multicolumn{2}{|c|}{ FOLHA } & \multicolumn{2}{|c|}{ HASTE } \\
\hline & & Q.M. & $\mathrm{F}$ & Q.M. & $\mathrm{F}$ & Q.M. & $\mathrm{F}$ \\
\hline Bloco & 2 & $488.913,29$ & - & $258.464,66$ & - & $170.643,25$ & - \\
\hline Lamina & 4 & $443.520,11$ & $1,84^{\mathrm{NS}}$ & $339.725,05$ & $2,06^{\mathrm{NS}}$ & $18.219,47$ & $0,30^{\mathrm{NS}}$ \\
\hline RESIDUO (A) & 8 & $239.912,72$ & - & $164.540,53$ & - & $59.586,81$ & - \\
\hline PARCELAS & 14 & - & - & - & - & - & - \\
\hline Dose $\mathrm{N}$ & 4 & $34.966 .393,64$ & $181,58^{* * *}$ & $25.293 .775,78$ & $121,17^{* * *}$ & $980.202,43$ & $32,68^{* * *}$ \\
\hline Lam*Dos & 16 & $378.126,34$ & $1,96^{*}$ & $286.312,32$ & $1,37^{\mathrm{NS}}$ & $30.192,38$ & $1,00^{\mathrm{NS}}$ \\
\hline RESIDUO (B) & 40 & $192.561,08$ & - & $208.740,66$ & - & $29.993,96$ & - \\
\hline SUBPARCELAS & 74 & - & - & - & - & - & - \\
\hline Coleta & 2 & $33.153 .658,70$ & $307,13^{* * *}$ & $35.871 .140,91$ & $281,61^{* * * *}$ & $355.690,66$ & $14,01^{* * *}$ \\
\hline Lam*Col & 8 & $300.160,02$ & $2,78^{* *}$ & $224.596,60$ & $1,76^{\circledR}$ & $33.124,35$ & $1,30^{\mathrm{NS}}$ \\
\hline Dos*Col & 8 & $2.107 .863,73$ & $19,52^{* * *}$ & $1.800 .387,48$ & $14,13^{* * * *}$ & $51.756,77$ & $2,03^{*}$ \\
\hline Lam*Dos*Col & 32 & $151.319,74$ & $1,40^{\circledR}$ & $143.966,96$ & $1,13^{\mathrm{NS}}$ & $16.062,88$ & $0,63^{\mathrm{NS}}$ \\
\hline RESIDUO (C) & 100 & $107.944,54$ & - & $127.378,64$ & - & $25.385,55$ & - \\
\hline TOTAL & 224 & - & - & - & - & - & - \\
\hline
\end{tabular}

Tabela 4. Análise da variância da massa seca total, folha e haste em capim Tanzânia, das três estação de cultivo (Verão, Inverno e Primavera), em Piracicaba, SP.

\begin{tabular}{|c|c|c|c|c|c|c|c|}
\hline \multirow[b]{3}{*}{ Causas de Variação } & \multirow[b]{3}{*}{ G.L. } & \multicolumn{6}{|c|}{ Massa Seca $\left({\mathrm{MS} . \mathrm{Ha}^{-1}}^{-1}\right.$ Período ou Coleta $\left.{ }^{-1}\right)$} \\
\hline & & \multicolumn{2}{|c|}{ TOTAL } & \multicolumn{2}{|c|}{ FOLHA } & \multicolumn{2}{|c|}{ HASTE } \\
\hline & & Q.M. & $\mathrm{F}$ & Q.M. & $\mathrm{F}$ & Q.M. & $\mathrm{F}$ \\
\hline Bloco & 2 & $613.461,06$ & - & $29.589,36$ & - & $419.734,44$ & - \\
\hline Lamina & 4 & $597.554,49$ & $3,22^{*}$ & $154.512,36$ & $3,46^{@}$ & $141.166,72$ & $2,06^{\mathrm{NS}}$ \\
\hline RESIDUO (A) & 8 & $185.769,93$ & - & $44.673,39$ & - & $68.471,28$ & - \\
\hline PARCELAS & 14 & - & - & - & - & - & - \\
\hline Dose $\mathrm{N}$ & 4 & $20.877 .137,07$ & $99,36^{* * *}$ & $11.158 .836,06$ & $92,03^{* * *}$ & $1.679 .482,41$ & $34,44^{* * *}$ \\
\hline Lam*Dos & 16 & $584.844,80$ & $2,78^{* *}$ & $354.551,58$ & $2,92^{* *}$ & $49.077,87$ & $1,01^{\mathrm{NS}}$ \\
\hline RESIDUO (B) & 40 & $210.115,97$ & - & $121.246,91$ & - & $48.760,83$ & - \\
\hline SUBPARCELAS & 74 & - & - & - & - & - & - \\
\hline Estação & 2 & $6.711 .758,86$ & $468,54^{* * *}$ & $67.666 .610,63$ & $770,68^{* * *}$ & $1.406 .199,79$ & $63,71^{* * *}$ \\
\hline Lam*Ést & 8 & $652.441,58$ & $4,55^{* * *}$ & $225.683,85$ & $2,57^{*}$ & $101.351,28$ & $4,58^{* * * *}$ \\
\hline Dos*Ést & 8 & $1.434 .271,19$ & $10,01^{* * *}$ & $1.510 .571,25$ & $17,20^{* * *}$ & $35.013,62$ & $1,58^{\mathrm{NS}}$ \\
\hline Lam*Dos*Ést & 32 & $258.280,31$ & $1,80^{*}$ & $180.474,54$ & $2,06^{* *}$ & $23.590,64$ & $1,07^{\mathrm{NS}}$ \\
\hline RESIDUO (C) & 100 & $143.249,67$ & - & $87.801,72$ & - & $2.214 .082,68$ & - \\
\hline TOTAL & 224 & - & - & - & - & - & - \\
\hline
\end{tabular}




\subsection{Avaliação da Fertilidade na Área Experimental}

A descrição do perfil do solo de um local próximo a área experimental, como as análises granulométrica e de fertilidade do solo, encontram-se no Anexo 1 e Tabelas de 5 a 8.

Os solos classificados como Terra Roxa Estruturada eutrófica (área experimental), A moderado textura argilosa (Anexo 1), apresentam características físicas de serem profundos, permeáveis, e apresentarem textura argilosa em todo perfil, com incremento de argila no horizonte B (Tabela 5). Essa característica o condiciona a apresentar maior microporosidade, a qual pode restringir a movimentação da água através do perfil e assim afetar a aeração em períodos de maior intensidade de chuva, como também menor densidade de solo (mais nítido em profundidade devida a compactação superficial) (Tabela 5) . Quanto às características químicas, são solos com boa fertilidade natural e teores de máteria orgânica de médios a altos nos horizontes superficiais, com soma de bases (SB) alta e saturação de bases (V) elevada em todo perfil, o que os caracterizam como eutróficos (Adámoli et al., 1985).

Observando os valores de $\mathrm{pH}$ e $\mathrm{V} \%$ apresentados nas Tabelas de 6 a 8, nas três profundidades de coleta, tem-se que mesmo sendo os valores de $\mathrm{pH}$ iniciais considerados elevados, seu valores (de porcentagem) de saturação de bases seriam considerados como excelentes, o que segundo Werner (1994) seria ideal para quando se trabalha em sistemas de manejo intensivo nos quais se faz uso de altas doses de adubos fertilizantes.

Werner et al. (1996) dentro de uma proposta, para o Estado de São Paulo, de distribuição das plantas forrageiras tropicais em dez grupos distintos, considerando a exigência das plantas à fertilidade do solo (tolerância a acidez) e fase de desenvolvimento (formação e manutenção), indicam que valores de V\% de 60 a $70 \%$, para gramíneas do gênero Panicum, quando de sua formação ou manutenção, seriam consideradas ideais no solo. Sendo que estes valores aproximariam-se àqueles sugeridos por Corsi e Nussio (1993), que seriam de V\% entre 70 a $80 \%$. 
Tabela 5. Análise granulométrica em amostras de terra na camada de $020 \mathrm{~cm}, 20-40$ cm e 40-60 cm, da área para pastagem de capim Tanzânia estabelecido numa Terra Roxa Estruturada, avaliados em área de pivô na Fazenda Areão, Piracicaba, SP.

\begin{tabular}{ccccccc}
\hline $\begin{array}{c}\text { Profundidade } \\
(\mathrm{cm})\end{array}$ & Areia Total & $\begin{array}{r}\text { Silte } \\
\%\end{array}$ & Argila Total & $\begin{array}{c}\text { Classe de } \\
\text { Textura }\end{array}$ & $\begin{array}{c}\text { Porosidade } \\
(\%)\end{array}$ & $\begin{array}{c}\text { Ds }^{1} \\
\left(\mathrm{~g} / \mathrm{cm}^{3}\right)\end{array}$ \\
\hline $0-20$ & 31 & 20 & 49 & Argilosa & 40 & 1.64 \\
$20-40$ & 20 & 19 & 61 & M. Argilosa & 45 & 1.47 \\
$40-60$ & 25 & 16 & 59 & Argilosa & 49 & 1.38 \\
\hline
\end{tabular}

1- Densidade do solo.; M. - Muito.

Deve-se tomar cuidado com os valores de V\% encontrados no solo de pastagens, pois existe uma correlação acentuada com a ocorrência de deficiência nutricional por micronutrientes, desequilíbrio entre o cálcio , magnésio e potássio ( Costa et al., 2001), principalmente quando se considera sistemas de manejo intensivo como é o pastejo rotacionado .

Os valores de V\% obtidos durante a condução do experimento foram tidos como satisfatório para o desenvolvimento do capim-Tanzânia, em todas as profundidades e períodos analisados (Tabelas 6 a 8 ). Os teores de cálcio e magnésio, que foram encontrados sempre em níveis altos no solo, devem ser os elementos responsáveis pelos elevados valores de V\% encontrados, uma vez que os valores de potássio mantiveram-se baixos, principalmente em profundidade no solo.

Pode-se observar que, na profundidade de 40 a $60 \mathrm{~cm}$ e doses de nitrogênio acima de $275 \mathrm{~kg} \mathrm{~N} \cdot \mathrm{ha}^{-1} \cdot \mathrm{ano}^{-1}$, houve aumento nos valores de V\% no final do experimento (Tabela 8).

Alguns fatores podem estar envolvidos neste aumento, dentre eles as adubações fosfatadas com superfosfato simples, que apresentando gesso $\left(\mathrm{SO}_{4}{ }^{--}\right)$teria uma ação potencial como carregador de nutrientes através do perfil do solo.

Em solos que predominam óxidos de ferro e alumínio, além de caulinita, pode haver adsorção específica do sulfato no solo, onde com o aumento de seu pH há efeito 
direto nesta adsorção (Raij, 1991). Assim, os altos teores de enxofre em todo perfil (Tabelas de 6 a 8), na forma de sulfato, poderiam estar facilitando esta lixiviação de macronutrientes ( $\mathrm{Ca}$ e $\mathrm{Mg}$ ) no solo. Também não se deve esquecer que o nitrato presente no adubo nitrogenado usado poderia estar colaborando no aumento do potencial de lixiviação dos nutrientes junto com o enxofre.

Maria et al. (1993), em estudo com colunas de solo montadas em laboratório, observaram que ao usar gesso, quantidades significativas de $\mathrm{Ca}^{+2}, \mathrm{Mg}^{+2}, \mathrm{~K}^{+}$e $\mathrm{Al}^{+3}$ foram obtidas na solução percolada no solo. Assim, tanta a aplicação das maiores lâminas de irrigação no experimento, quanto os períodos de maior precipitação, poderiam explicar esta elevação de V\% em profundidade.

Quando do manejo intensivo de pastagem (como o rotacionado usado neste experimento) a sua longevidade ou a sua resistência à degradação dependem, além de fatores ligados ao manejo da planta forrageira, das condições climáticas e qualidade dos animais, mas também de eficiente manejo para manutenção da fertilidade no solo, no qual Silva (1995) sugere que pastos manejados para produções elevadas de forragem deveriam ser encarados como culturas .

Considerando então o sistema rotacionado, a intensificação da produção da pastagem a partir de altas taxas de lotação animal só é possível, se forem atendidas as exigências nutricionais destas plantas forrageiras através do fornecimento de grandes quantidades de nutrientes (Aguiar, 1997).

Assim, a reposição ao solo daqueles nutrientes que apresentam maior exportação através do pastejo, torna-se de grande importante, onde o manejo da fertilidade com a análise do solo, pode permitir controle satisfatório dos teores de $\mathrm{P}, \mathrm{K}$, Ca em níveis ideais às plantas no solo. Considerando que os valores de cálcio, magnésio e enxofre no solo encontraram-se em quantidades suficientes no solo, e que o nitrogênio é o elemento que esta sendo estudado, cuidado especial deve ser dado aos teores de $\mathrm{P}$ e $\mathrm{K}$, uma vez que são os elementos, junto com o nitrogênio, que apresentaram significativos níveis de extração pelo capim-Tanzânia (Tabela de 6 a 8).

Considerando a adubação sugerida por Werner et al. (1996), a aplicação de $70 \mathrm{~kg}$ $\mathrm{P}_{2} \mathrm{O}_{5} \cdot \mathrm{ha}^{-1}$ em área total, proporcionaram a elevação dos teores de $\mathrm{P}$ de baixo para 
médios, após o início do experimento (Tabela 6), mas como observado nas Tabelas 7 e 8, os teores de fósforo caíram para níveis baixos na camada superficial, mesmo fazendo uso da adubação de manutenção de $40 \mathrm{~kg} \mathrm{P}_{2} \mathrm{O}_{5} \cdot \mathrm{ha}^{-1}$ após cada análise de solo semestral.

Esta rápida diminuição dos teores de fósforo superficial, mesmo nos tratamentos que receberam pequena ou nenhuma adubação nitrogenada, poderia ser explicado pela possível fixação do fósforo no solo, o que seria pouco provável, uma vez que as condições químicas ( $\mathrm{pH}$ e $\mathrm{m} \%$ ) encontravam-se em condições que proporcionariam uma maior disponibilidade deste nutriente a planta. O mais provável, seria a presença de um ambiente semelhante àquele apresentado por Corsi e Nussuio (1992), citados por Werner et al. (2001), no qual uma boa cobertura morta proveniente de pressão de pastejo mais leve em pastagens manejada corretamente, permitiria a recuperação rápida do crescimento das raízes ativas na superfície do solo, proporcionando assim maior eficiência na absorção do fósforo aplicada na superfície do solo. $\mathrm{O}$ aumento da matéria orgânica no solo é apresentado nas Tabela 6 a 8 , e o maior acúmulo de raízes nas camadas de $0-20 \mathrm{~cm}$ na Figura 1 .

Os valores iniciais de potássio na superfície do solo foram considerados de alto a médio até a profundidade de $40 \mathrm{~cm}$, o que não justificou o uso da adubação potássica de formação. Após o início do experimento, Tabela 6, pode-se observar queda nos teores para médios superficialmente $(0-20 \mathrm{~cm}$.), e depois para baixo, com o decorrer do experimento (Tabela 7 e 8 ).

A necessidade de atenção especial com o potássio é necessária, uma vez que este elemento , junto com o nitrogênio, são os mais exigidos pelas gramíneas do gênero Panicum, apresentando necessidade de $363 \mathrm{~kg} \mathrm{~K} \cdot \mathrm{ha}^{-1}$ para a produção de 23 t.ha ${ }^{-1}$ de MS (Gloria, 1994).

As amostras de solo foram sempre retiradas dentro da área útil de coleta amostral, na qual as plantas forrageiras deste local eram cortadas e removidas para pesagem e posterior determinação da massa seca. Esta exportação de nutrientes ( K e P) através da forragem retirada da área, poderia explicar a diminuição em profundidade dos teores de potássio a níveis baixo e muito baixo. 
Monteiro (1995) recomenda para áreas que tem remoção de forragem, a reposição do potássio à base de $2 \%$ de $\mathrm{K}$ (ou $4 \%$ de $\mathrm{KCl}$ ) sobre a massa seca da forragem removida, com aplicação do adubo após cada corte do capim. Neste experimento, foi feita a reposição proposta por Werner et al. (1996) de $40 \mathrm{~kg} \mathrm{deK}_{2} \mathrm{O} . h a^{-1}$ semestralmente determinadas usando os resultados apresentados pelas análises de solo, para os teores de potássio presentes no solo (Tabela 7 e 8). Considerando reposição com base a $2 \%$ sobre a massa seca , a reposição de $80 \mathrm{~kg} \mathrm{~K}_{2} \mathrm{O} \mathrm{ha}^{-1}$ no solo, ficou abaixo da quantidade necessária de $191 \mathrm{~kg} \mathrm{~K}_{2} \mathrm{O}_{\mathrm{Oha}}{ }^{-1}$ (tratamento de $0 \mathrm{kgN} \mathrm{ha}^{-1} \cdot$ ano $^{-1}$ ) a $485 \mathrm{~kg}$ $\mathrm{K}_{2} \mathrm{O} \mathrm{ha}^{-1}$ (tratamento de $2079 \mathrm{kgN} \cdot \mathrm{ha}^{-1} \cdot \mathrm{ano}^{-1}$ ).

Observa-se, tanto para o fósforo como para o potássio, uma diminuição significativa nos teores destes nutrientes no final do experimento, entre as profundidades de 20 a $60 \mathrm{~cm}$, os quais continham $11 \%$ do total das raízes da gramínea (Figura 1). Estas raízes em profundidades mostraram um a tendência de funcionalidade, tanto no processo de absorção de nutrientes ou água. Assim, naqueles momentos experimentais que não foram observado o efeito do uso das lâminas de irrigação, quando o solo apresentava-se dentro de condição de umidade favorável em profundidade, estas raízes poderiam estar suprindo a planta com água e nutrientes.

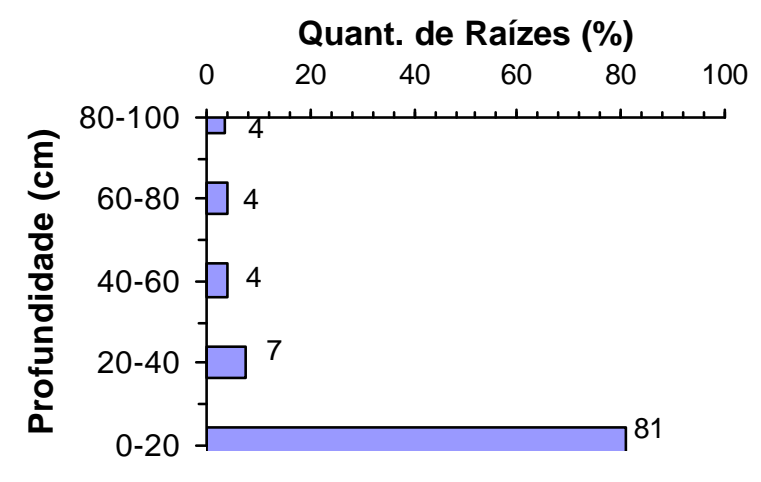

Figura 1- Distribuição de raízes em diferentes profundidades de amostragem, em uma pastagem de capim Tanzânia estabelecido em Terra Roxa Estruturada, avaliado na Fazenda Areão, Piracicaba,SP. 
Tabela 6. Análises químicas em amostras de terra na camada de $0-20 \mathrm{~cm}, 20-40 \mathrm{~cm}$ e $40-60 \mathrm{~cm}$, de tratamento adubado com diferentes doses de nitrogênio, em pastagem de capim Tanzânia estabelecida numa Terra Roxa Estruturada, em dois períodos amostrais, na Fazenda Areão, Piracicaba, SP.

\begin{tabular}{|c|c|c|c|c|c|c|c|c|c|c|c|c|c|c|c|}
\hline $\begin{array}{c}\text { Prof. } \\
\mathrm{cm} .\end{array}$ & $\begin{array}{c}\text { Dose N } \\
\mathrm{kgN} / \text { ha.ano }\end{array}$ & Coletas & $\begin{array}{c}\mathrm{pH} \\
\mathrm{CaCl}_{2}\end{array}$ & $\begin{array}{l}\text { M.O. } \\
\text { g dm }^{-3}\end{array}$ & \multicolumn{2}{|c|}{$\mathrm{mg} \cdot \mathrm{dm}^{-3}$} & \multicolumn{7}{|c|}{ mmolc. $\mathrm{dm}^{-3}$} & \multicolumn{2}{|c|}{$\%$} \\
\hline \multirow{6}{*}{$0-20$} & Inicial & $15 / 12 / 99$ & $4.7^{\mathrm{A}}$ & 20 & $10^{\mathrm{B}}$ & $65^{A}$ & $3.9^{\mathrm{A}}$ & $39^{A}$ & $19^{A}$ & 1 & 38 & 61.9 & 99.9 & $62^{\mathrm{M}}$ & 2 \\
\hline & 0 & & $5.0^{\mathrm{A}}$ & 22 & $14^{\mathrm{M}}$ & $46^{\mathrm{A}}$ & $2.3^{\mathrm{M}}$ & $31^{\mathrm{A}}$ & $15^{\mathrm{A}}$ & 0 & 31 & 48.3 & 79.3 & $61^{\mathrm{M}}$ & 0 \\
\hline & 100 & & - & - & - & - & - & - & - & - & - & - & - & - & - \\
\hline & 275 & $30 / 01 / 01$ & $5.0^{\mathrm{A}}$ & 17 & $13^{\mathrm{M}}$ & $57^{\mathrm{A}}$ & $2.3^{\mathrm{M}}$ & $28^{\mathrm{A}}$ & $15^{\mathrm{A}}$ & 0 & 34 & 45.3 & 79.3 & $57^{\mathrm{M}}$ & 0 \\
\hline & 756 & & $5.1^{\mathrm{M}}$ & 31 & $17^{\mathrm{M}}$ & $60^{\mathrm{A}}$ & $4.5^{\mathrm{A}}$ & $42^{\mathrm{A}}$ & $22^{\mathrm{A}}$ & 0 & 28 & 68.5 & 98.5 & $71^{\mathrm{A}}$ & 0 \\
\hline & 2079 & & $5.1^{\mathrm{M}}$ & 31 & $23^{\mathrm{M}}$ & $42^{\mathrm{A}}$ & $2.9^{\mathrm{M}}$ & $38^{\mathrm{A}}$ & $19^{\mathrm{A}}$ & 0 & 34 & 59.9 & 93.9 & $64^{\mathrm{M}}$ & 0 \\
\hline \multirow{6}{*}{$20-40$} & Inicial & $15 / 12 / 99$ & $5.0^{\mathrm{A}}$ & 15 & $10^{\mathrm{B}}$ & $117^{\mathrm{A}}$ & $1.8^{\mathrm{M}}$ & $39^{\mathrm{A}}$ & $18^{\mathrm{A}}$ & 0 & 31 & 58.8 & 99.9 & $62^{\mathrm{M}}$ & 0 \\
\hline & 0 & & $5.1^{\mathrm{M}}$ & 21 & $8^{\text {B }}$ & $124^{\mathrm{A}}$ & $1.3^{\mathrm{B}}$ & $26^{\mathrm{A}}$ & $13^{\mathrm{A}}$ & 0 & 31 & 40.3 & 71.3 & $57^{\mathrm{M}}$ & 0 \\
\hline & 100 & & - & - & - & - & - & - & - & - & - & - & - & - & - \\
\hline & 275 & $30 / 01 / 01$ & $5.2^{\mathrm{M}}$ & 25 & $8^{\mathrm{B}}$ & $117^{\mathrm{A}}$ & $1.5^{\mathrm{B}}$ & $29^{\mathrm{A}}$ & $15^{\mathrm{A}}$ & 0 & 25 & 45.5 & 70.5 & $65^{\mathrm{M}}$ & 0 \\
\hline & 756 & & $5.3^{\mathrm{M}}$ & 22 & $14^{\mathrm{M}}$ & $134^{\mathrm{A}}$ & $2.0^{\mathrm{M}}$ & $40^{\mathrm{A}}$ & $22^{\mathrm{A}}$ & 0 & 28 & 64.0 & 92.0 & $70^{\mathrm{M}}$ & 0 \\
\hline & 2079 & & $5.2^{\mathrm{M}}$ & 26 & $10^{\mathrm{B}}$ & $83^{\mathrm{A}}$ & $1.2^{\mathrm{B}}$ & $27^{\mathrm{A}}$ & $14^{\mathrm{A}}$ & 0 & 25 & 42.2 & 67.2 & $63^{\mathrm{M}}$ & 0 \\
\hline \multirow{6}{*}{$40-60$} & Inicial & $15 / 12 / 99$ & $4.6^{\mathrm{A}}$ & 14 & $5^{\mathrm{B}}$ & $127^{\mathrm{A}}$ & $1.3^{\mathrm{B}}$ & $32^{\mathrm{A}}$ & $14^{\mathrm{A}}$ & 0 & 28 & 47.3 & 75.3 & $63^{\mathrm{M}}$ & 0 \\
\hline & 0 & & $5.2^{\mathrm{M}}$ & 21 & $8^{\text {B }}$ & $148^{\mathrm{A}}$ & $1.2^{\mathrm{B}}$ & $31^{\mathrm{A}}$ & $14^{\mathrm{A}}$ & 0 & 25 & 46.2 & 71.2 & $65^{\mathrm{M}}$ & 0 \\
\hline & 100 & & - & - & - & - & - & - & - & - & - & - & - & - & - \\
\hline & 275 & $30 / 01 / 01$ & $5.4^{\mathrm{M}}$ & 19 & $6^{\mathrm{B}}$ & $148^{\mathrm{A}}$ & $1.0^{\mathrm{B}}$ & $30^{\mathrm{A}}$ & $13^{\mathrm{A}}$ & 0 & 25 & 44 & 69.0 & $64^{\mathrm{M}}$ & 0 \\
\hline & 756 & & $5.3^{\mathrm{M}}$ & 19 & $9^{\mathrm{B}}$ & $141^{\mathrm{A}}$ & $1.2^{\mathrm{B}}$ & $31^{\mathrm{A}}$ & $13^{\mathrm{A}}$ & 0 & 25 & 45.2 & 70.2 & $64^{\mathrm{M}}$ & 0 \\
\hline & 2079 & & $5.4^{\mathrm{M}}$ & 18 & $8^{\text {B }}$ & $148^{\mathrm{A}}$ & $1.1^{\mathrm{B}}$ & $35^{\mathrm{A}}$ & $14^{\mathrm{A}}$ & 0 & 25 & 50.1 & 75.1 & $67^{\mathrm{M}}$ & 0 \\
\hline
\end{tabular}

Amostra composta feita com solo de todos bloco e lâminas irrigada para cada tratamento de adubação (15 sub-amostras).

1 - Resina; 2 - Soma de Bases; 3 - CTC a pH=7,0 ; 4 - Saturação por bases.

A - Alto, MA - Muito Alto, M - Médio, B - Baixo e MB - Muito Baixo. 
Tabela 7. Análises químicas em amostras de terra na camada de 0-20 cm, 20-40 cm e 40-60 cm , de tratamento adubado com diferentes doses de nitrogênio, em pastagem de capim Tanzânia estabelecido numa Terra Roxa Estruturada, na Fazenda Areão, Piracicaba, SP. Data de coleta das amostras: 23/08/2001.

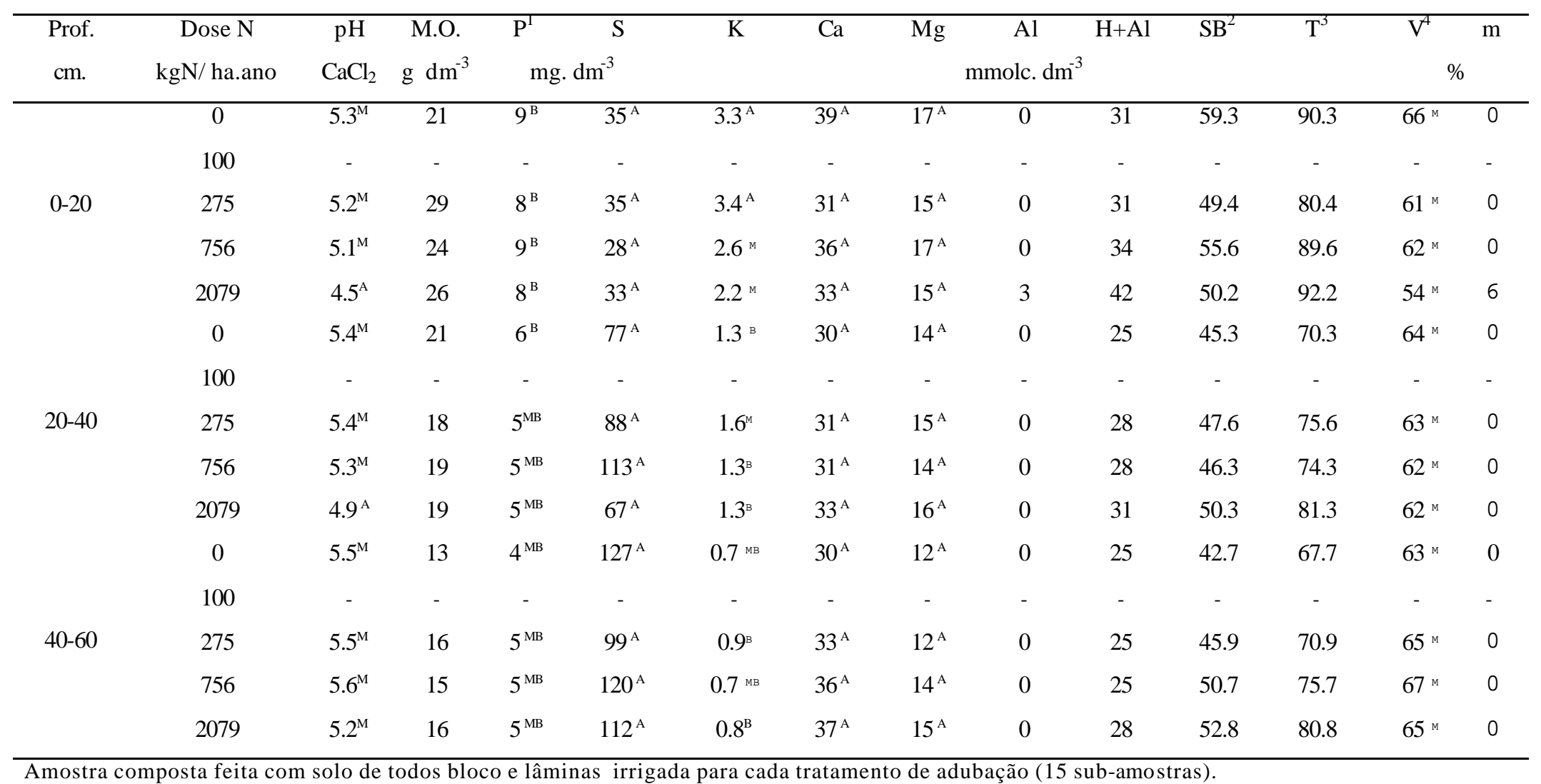

1 - Resina; 2 - Soma de Bases; 3 - CTC a pH=7,0 ; 4 - Saturação por bases.

A - Alto, MA - Muito Alto, M - Médio, B - Baixo e MB - Muito Baixo. 
Tabela 8. Análises química em amostras de terra na camada de 0-20 cm, 20-40 cm e 40-60 cm, de tratamento adubado com diferentes doses de nitrogênio, em pastagem de capim Tanzânia estabelecido numa Terra Roxa Estruturada, na Fazenda Areão, Piracicaba, SP. Data de coleta das amostras: 10/12/2001.

\begin{tabular}{|c|c|c|c|c|c|c|c|c|c|c|c|c|c|c|}
\hline Prof. & Dose N & $\mathrm{pH}$ & M.O. & $\mathrm{P}^{1}$ & $\mathrm{~S}$ & $\mathrm{~K}$ & $\mathrm{Ca}$ & $\mathrm{Mg}$ & $\mathrm{Al}$ & $\mathrm{H}+\mathrm{Al}$ & $\mathrm{SB}^{2}$ & $\mathrm{~T}^{3}$ & $\mathrm{~V}^{4}$ & $\mathrm{~m}$ \\
\hline $\mathrm{cm}$ & kgN/ ha.ano & $\mathrm{CaCl}_{2}$ & $\mathrm{~g} \mathrm{dm} \mathrm{m}^{-3}$ & \multicolumn{2}{|c|}{$\mathrm{mg} \cdot \mathrm{dm}^{-3}$} & \multicolumn{7}{|c|}{ mmolc. $\mathrm{dm}^{-3}$} & \multicolumn{2}{|l|}{$\%$} \\
\hline \multirow{5}{*}{$0-20$} & 0 & $5.3^{\mathrm{M}}$ & 25 & $7^{\text {в }}$ & $46^{\mathrm{A}}$ & $4.6^{\mathrm{A}}$ & $38^{\mathrm{A}}$ & $17^{\mathrm{A}}$ & 0 & 28 & 59.6 & 87.6 & $68.0^{\mathrm{M}}$ & 2 \\
\hline & 100 & $5.4^{\mathrm{M}}$ & 29 & $11^{\mathrm{B}}$ & $36^{\mathrm{A}}$ & $4.1^{\mathrm{A}}$ & $35^{\mathrm{A}}$ & $16^{\mathrm{A}}$ & 0 & 25 & 55.1 & 80.1 & $68.8^{\mathrm{M}}$ & 0 \\
\hline & 275 & $5.6^{\mathrm{B}}$ & 25 & $8^{\text {в }}$ & $38^{\mathrm{A}}$ & $3.6^{\mathrm{A}}$ & $30^{\mathrm{A}}$ & $14^{\mathrm{A}}$ & 0 & 25 & 47.6 & 72.6 & $65.6^{\mathrm{M}}$ & 0 \\
\hline & 756 & $5.5^{\mathrm{M}}$ & 26 & $13^{\mathrm{M}}$ & $32^{\mathrm{A}}$ & 1.0 & $42^{\mathrm{A}}$ & $20^{\mathrm{A}}$ & 0 & 22 & 63 & 85 & $74.1^{\mathrm{A}}$ & 0 \\
\hline & 2079 & $5.1^{\mathrm{M}}$ & 24 & $9^{\text {в }}$ & $42^{\mathrm{A}}$ & $1.3^{\text {в }}$ & $24^{\mathrm{A}}$ & $11^{\mathrm{A}}$ & 1 & 38 & 36.3 & 74.3 & $48.9^{\text {в }}$ & 0 \\
\hline \multirow{5}{*}{$20-40$} & 0 & $5.5^{\mathrm{M}}$ & 17 & $5^{\mathrm{MB}}$ & $76^{\mathrm{A}}$ & $1.3^{\text {в }}$ & $29^{A}$ & $14^{\mathrm{A}}$ & 0 & 22 & 44.3 & 66.3 & $66.8^{\mathrm{\mu}}$ & 0 \\
\hline & 100 & $5.5^{\mathrm{M}}$ & 18 & $4^{\mathrm{MB}}$ & $85^{\mathrm{A}}$ & $1.4^{\mathrm{B}}$ & $28^{\mathrm{A}}$ & $14^{\mathrm{A}}$ & 0 & 25 & 43.4 & 68.4 & $63.5^{\mathrm{M}}$ & 0 \\
\hline & 275 & $5.5^{\text {в }}$ & 17 & $5^{\mathrm{MB}}$ & $67^{\mathrm{A}}$ & $2.1^{\mathrm{MA}}$ & $28^{\mathrm{A}}$ & $13^{\mathrm{A}}$ & 0 & 22 & 43.1 & 65.1 & $66.2^{\mathrm{M}}$ & 0 \\
\hline & 756 & $5.8^{\mathrm{M}}$ & 16 & $5^{\mathrm{MB}}$ & $87^{\mathrm{A}}$ & $0.4^{\mathrm{MB}}$ & $29^{A}$ & $15^{\mathrm{A}}$ & 0 & 22 & 44.4 & 66.4 & $66.9^{\mathrm{M}}$ & 0 \\
\hline & 2079 & $5.4^{\mathrm{M}}$ & 15 & $4^{\mathrm{MB}}$ & $79^{\mathrm{A}}$ & $0.2^{\mathrm{MB}}$ & $34^{\mathrm{A}}$ & $15^{\mathrm{A}}$ & 0 & 20 & 49.2 & 69.2 & $71.1^{\mathrm{AM}_{\mathrm{M}}}$ & 0 \\
\hline \multirow{5}{*}{$40-60$} & 0 & $5.7^{\mathrm{B}}$ & 13 & $5^{\mathrm{MB}}$ & $103^{\mathrm{A}}$ & $0.6^{\mathrm{MB}}$ & $31^{\mathrm{A}}$ & $13^{\mathrm{A}}$ & 0 & 20 & 44.6 & 64.6 & $69.0^{\mathrm{M}}$ & 0 \\
\hline & 100 & $5.6^{\mathrm{B}}$ & 12 & $4^{\mathrm{MB}}$ & $101^{\mathrm{A}}$ & $0.5^{\mathrm{MB}}$ & $30^{\mathrm{A}}$ & $12^{\mathrm{A}}$ & 0 & 20 & 42.5 & 62.5 & $68.0^{\mathrm{M}}$ & 0 \\
\hline & 275 & $5.7^{\text {в }}$ & 14 & $11^{\mathrm{B}}$ & $93^{\mathrm{A}}$ & $2.0^{\mathrm{M}}$ & $34^{\mathrm{A}}$ & $15^{\mathrm{A}}$ & 0 & 18 & 51 & 69 & $73.9^{\mathrm{MA}}$ & 0 \\
\hline & 756 & $5.6^{\mathrm{B}}$ & 12 & $7^{\text {в }}$ & $108^{A}$ & $0.3^{\mathrm{MB}}$ & $36^{\mathrm{A}}$ & $16^{\mathrm{A}}$ & 0 & 20 & 52.3 & 72.3 & $72.3^{\mathrm{MA}^{\mathrm{A}}}$ & 0 \\
\hline & 2079 & $6.2^{\mathrm{MB}}$ & 13 & $8^{\text {в }}$ & $112^{\mathrm{A}}$ & $0.3^{\mathrm{MB}}$ & $45^{\mathrm{A}}$ & $17^{\mathrm{A}}$ & 0 & 15 & 62.3 & 77.3 & $80.6^{\mathrm{MA}^{\mathrm{A}}}$ & 0 \\
\hline
\end{tabular}




\subsection{Avaliação do efeito do uso de lâminas de irrigação}

Os resultados das equações de regressão para variação de lâmina de irrigação dentro de cada dose de adubação nitrogenada e coleta, e dentro de cada coleta em três estações climáticas, para a massa seca total e foliar em pastagem de capimTanzânia encontram-se nas Tabelas 9, 10 e 11.

Observando os resultados presentes nas Tabelas 9 e 10 referentes a análise tripla da interação fixando a lâmina de irrigação (Tabelas de 1 a 4), pode-se observar que não houve efeito da lâmina de irrigação dentro da maioria das doses de nitrogênio e épocas de coleta, dentro das três estações estudadas. Para a massa seca total, dois momentos foram significativos, um no qual presenciou-se o efeito negativo do uso de irrigação na produção ( $1^{\mathrm{a}}$. coleta), e outro no qual pode-se identificar o efeito de cada lâmina na produção do capim-Tanzânia (4 ${ }^{\text {a }}$.coleta) (Tabela 9).

O efeito da lâmina de irrigação, dentro da maioria das doses de nitrogênio e épocas de coleta, não mostrou efeito significativo na produção de massa seca foliar (Tabela 10). Considerando a coleta 4, na qual a massa seca total apresentou efeito da lâmina de irrigação, os efeito para massa seca foliar não foram claros, talvez em parte devido a ocorrência do florescimento neste período, e somado a influência individual de cada dose de nitrogênio usado, podem ter contribuído para o aumento no grau de variação dos dados coletados em cada sub-parcela experimental (Tabela 10). Esta hipótese pode ser considerada quando se encontra efeito significativo quadrático da interação de coleta e lâminas usada (Tabelas 1 e 11) na variação de produção de massa seca foliar na quarta coleta. Assim, a não ocorrência, como esperado, do efeito das lâminas de irrigação na produção de massa seca deve ser explicado considerando os efeitos de clima, físicos do solo e de desenvolvimento radicular das plantas, ou considerando a interação entre estes efeitos. 
Tabela 9. Equações de regressão para variação de lâmina de irrigação dentro de cada dose de adubação nitrogenada e coleta, em três estações climáticas para a massa seca total em pastagem de capim Tanzânia estabelecido numa Terra Roxa Estruturada, avaliados na Fazenda Areão, Piracicaba, SP.

\begin{tabular}{|c|c|c|c|c|c|c|c|c|c|}
\hline \multirow[b]{2}{*}{$\begin{array}{c}\text { Dose } \\
\mathrm{N}^{1}\end{array}$} & \multicolumn{3}{|c|}{ Verão } & \multicolumn{3}{|c|}{ Inverno } & \multicolumn{3}{|c|}{ Primavera } \\
\hline & $\mathrm{Co}^{2}$ & Equação & $\mathrm{R}^{2}$ & $\mathrm{Co}^{2}$ & Equação & $\mathrm{R}^{2}$ & $\mathrm{Co}^{2}$ & Equação & $\mathrm{R}^{2}$ \\
\hline 0 & & $5.671,41-27,37 x$ & $0,75^{*-1}$ & & $975,3+16,1 \mathrm{x}-0,129 \mathrm{x}^{2}$ & $0,78^{* * *}$ & & NS & - \\
\hline 100 & & $4.104,61-7,98 x$ & $0,30^{* *}$ & & $1.257,3+19,4 x-0,142 x^{2}$ & $0,86^{* *}$ & & NS & - \\
\hline 275 & 1 & NS & - & 4 & $1.317,9+3,87 \mathrm{x}$ & $0,31^{*}$ & 7 & NS & - \\
\hline 756 & & $4.635,27-9,95 x$ & $0,73^{*}$ & & $2.852,45-5,18 x$ & $0,70^{*}$ & & NS & - \\
\hline 2079 & & $5.501,56-11,10 x$ & $0,78^{*}$ & & $2.622,6+11,2 x-0,084 x^{2}$ & $0,29^{*}$ & & NS & - \\
\hline 0 & & NS & - & & NS & - & & NS & - \\
\hline 100 & & NS & - & & NS & - & & NS & - \\
\hline 275 & 2 & NS & - & 5 & NS & - & 8 & NS & - \\
\hline 756 & & NS & - & & NS & - & & NS & - \\
\hline 2079 & & NS & - & & NS & - & & NS & - \\
\hline 0 & & NS & - & & NS & - & & NS & - \\
\hline 100 & & $2.211,31-9,14 x$ & $0,63^{*}$ & & NS & - & & NS & - \\
\hline 275 & 3 & NS & - & 6 & NS & - & 9 & NS & - \\
\hline 756 & & NS & - & & NS & - & & NS & - \\
\hline 2079 & & $1.927,39+8.61$ & $0,75^{*}$ & & NS & - & & NS & - \\
\hline
\end{tabular}

1- kg N/ha.ano 2 - Co - Coleta

$* \mathrm{p}<0,05 ; * * \mathrm{p}<0,01 ; * * * \mathrm{p}<0,001$. 
Tabela 10. Equações de regressão para variação de lâmina de irrigação dentro de cada dose de adubação nitrogenada e coleta, em três estações climáticas para a massa seca folha em pastagem de capim Tanzânia estabelecido numa Terra Roxa Estruturada, avaliados na Fazenda Areão, Piracicaba, SP.

\begin{tabular}{|c|c|c|c|c|c|c|c|c|c|}
\hline \multirow[b]{2}{*}{$\begin{array}{c}\text { Dose } \\
\mathrm{N}^{1}\end{array}$} & \multirow[b]{2}{*}{ Coleta } & \multicolumn{2}{|l|}{ Verão } & \multicolumn{4}{|c|}{ Inverno } & \multicolumn{2}{|c|}{ Primavera } \\
\hline & & Equação & $\mathrm{R}^{2}$ & Coleta & Equação & $\mathrm{R}^{2}$ & Coleta & Equação & $\mathrm{R}^{2}$ \\
\hline 0 & & $4846,03-21,48 x$ & $0,70^{*}$ & & NS & - & & NS & - \\
\hline 100 & & NS & - & & NS & - & & NS & - \\
\hline 275 & 1 & NS & - & 4 & NS & - & 7 & NS & - \\
\hline 756 & & NS & - & & NS & - & & NS & - \\
\hline 2079 & & NS & - & & NS & - & & NS & - \\
\hline 0 & & NS & - & & NS & - & & NS & - \\
\hline 100 & & NS & - & & NS & - & & NS & - \\
\hline 275 & 2 & NS & - & 5 & NS & - & 8 & NS & - \\
\hline 756 & & NS & - & & NS & - & & NS & - \\
\hline 2079 & & NS & - & & NS & - & & NS & - \\
\hline 0 & & NS & - & & NS & - & & NS & - \\
\hline 100 & & $1964,49-8,07 x$ & $0,61^{*}$ & & NS & - & & NS & - \\
\hline 275 & 3 & NS & - & 6 & NS & - & 9 & NS & - \\
\hline 756 & & NS & - & & NS & - & & NS & - \\
\hline 2079 & & $1446,49+7,53 x$ & $0,77^{*}$ & & NS & - & & NS & - \\
\hline
\end{tabular}


Tabela 11. Equações de regressão para variação de lâmina de irrigação dentro de cada coleta, nas três estações climáticas para a massa seca total e foliar em pastagem de capim Tanzânia estabelecido numa Terra Roxa Estruturada, avaliados na Fazenda Areão, Piracicaba, SP.

\begin{tabular}{|c|c|c|c|c|c|}
\hline \multirow{2}{*}{ Estação } & \multirow{2}{*}{ Coleta } & M.S. Total & \multicolumn{3}{|c|}{ M.S. Folha } \\
\hline & & Equação & $\mathrm{R}^{2}$ & Equação & $\mathrm{R}^{2}$ \\
\hline & 1 & $4.752,9-12,46 x$ & 0,88 & $3976,6-7,30 x$ & $0.84^{* \ldots+1}$ \\
\hline \multirow[t]{3}{*}{ Verão } & 2 & NS & - & NS & - \\
\hline & 3 & NS & - & NS & - \\
\hline & 4 & $1.770,2+10,9 x-0,084 x^{2}$ & $0,96^{* *}$ & $832,6+5,2 x-0,037 x^{2}$ & $0,82^{* *}$ \\
\hline \multirow[t]{3}{*}{ Inverno } & 5 & $768,3-1,62 x$ & $0,61^{*}$ & $602,4-1,31 x$ & $0,65^{*}$ \\
\hline & 6 & NS & - & NS & - \\
\hline & 7 & NS & - & $488,53+1,96 x$ & $0,82^{*}$ \\
\hline \multirow[t]{2}{*}{ Primavera } & 8 & $973,13+2,65 x$ & $0,68^{*}$ & $916,19+2,01 x$ & $0,60^{*}$ \\
\hline & 9 & NS & - & NS & - \\
\hline
\end{tabular}

\subsubsection{Variação do clima}

A variação de temperatura, precipitação, radiação global e evapotranspiração (ETca) obtidos dentro da área experimental e na estação meteorológica padrão do Departamento de Física e Meteorologia Ambiental da ESALQ, são mostrados nas Figuras 2, 3 e 5, e as produções médias totais de massa seca na Figura 4.

Os valores de temperatura, precipitação, evapotranspiração (ETca) e radiação global durante o estudo, foram máximos entre os meses de novembro de 2000 a abril de 2001, e mínimos entre os meses de maio a agosto de 2001 (Figura 2 e 3). A associação destes fatores, contribuíram significativamente para a ocorrência da estacionalidade de produção e crescimento do capim-Tanzânia, destacando-se a temperatura, a radiação global (afetada pelo comprimento do dia), e em menor escala o estresse hídrico no solo (Figura 2 e 3), como os principais fatores indutores de sazonalidade de produção (Figura 4). 


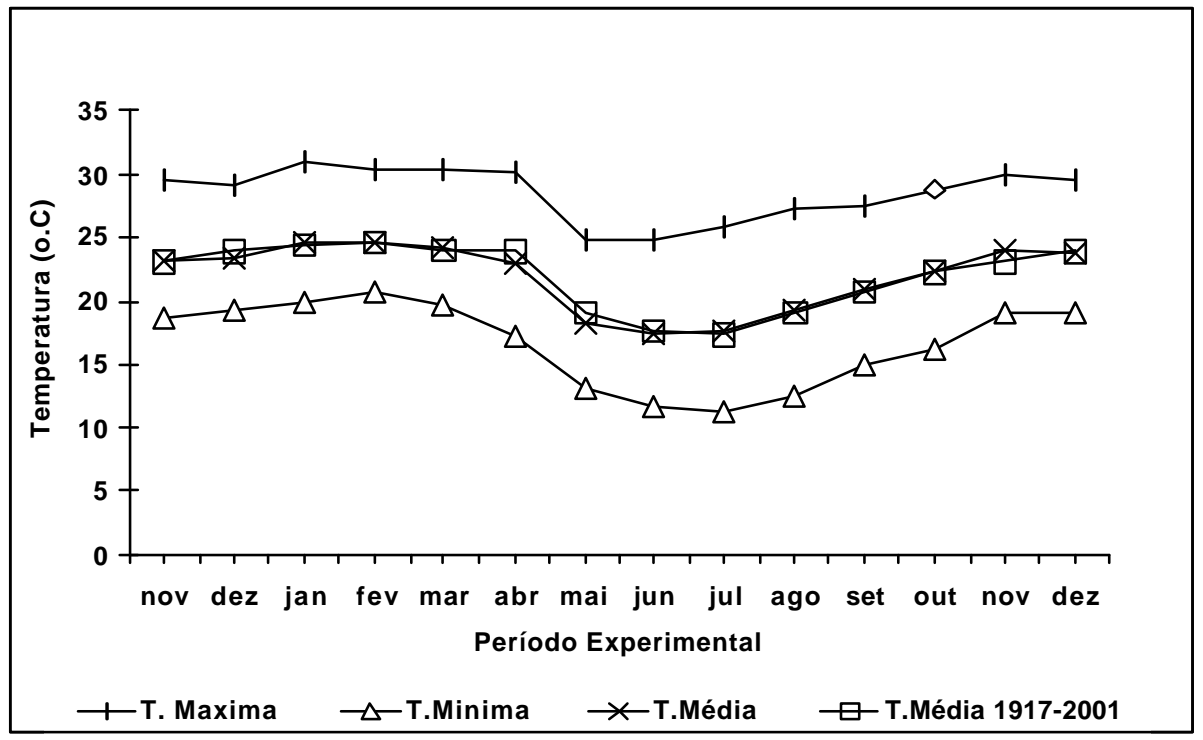

Figura 2 - Variação mensal de temperatura (máxima, mínima e média ) em área de pastagem de capim Tanzânia e com dados climatológicos médios para o período entre 1917-2001, em Piracicaba, SP .

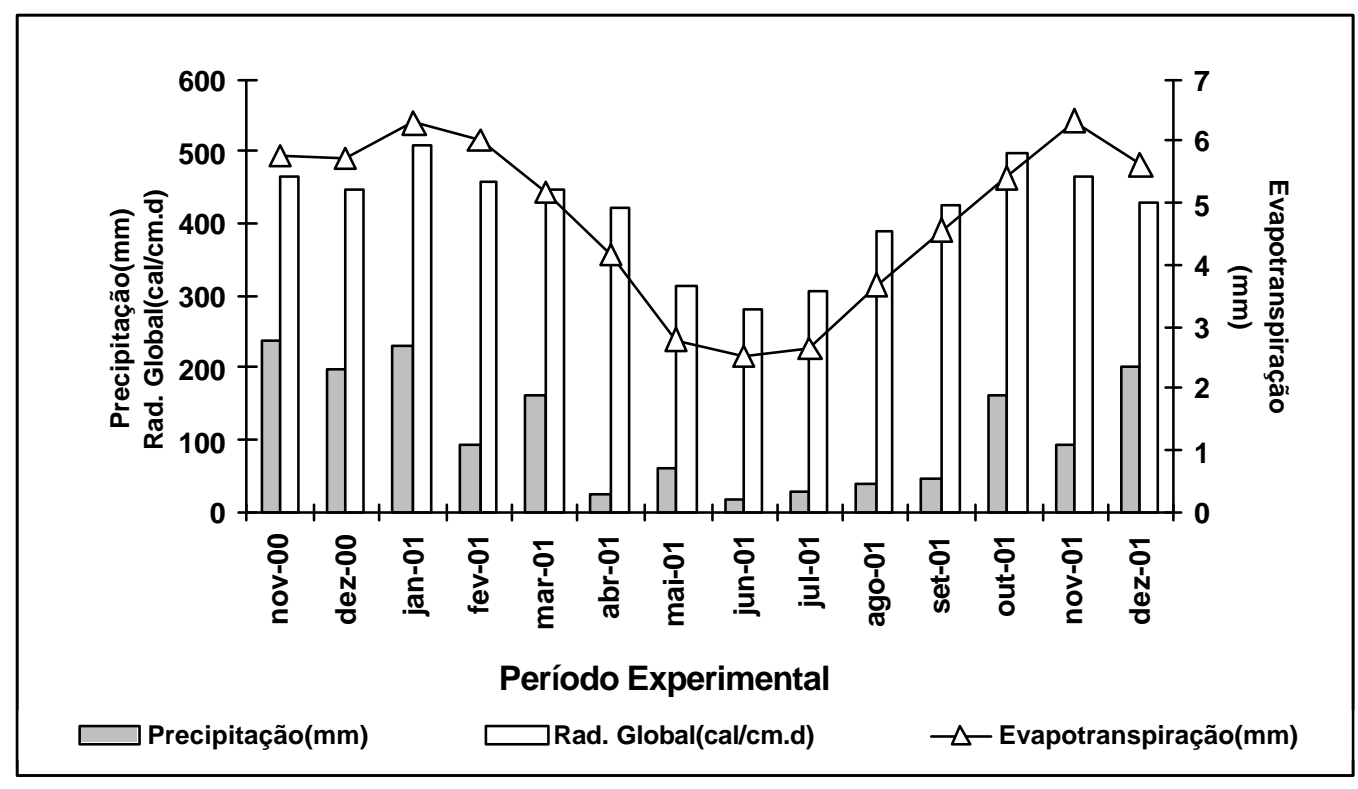

Figura 3 - Variação mensal de precipitação, radiação global e evapotranspiração em área de pastagem com capim-Tanzânia, em Piracicaba, SP, durante o período experimental. 


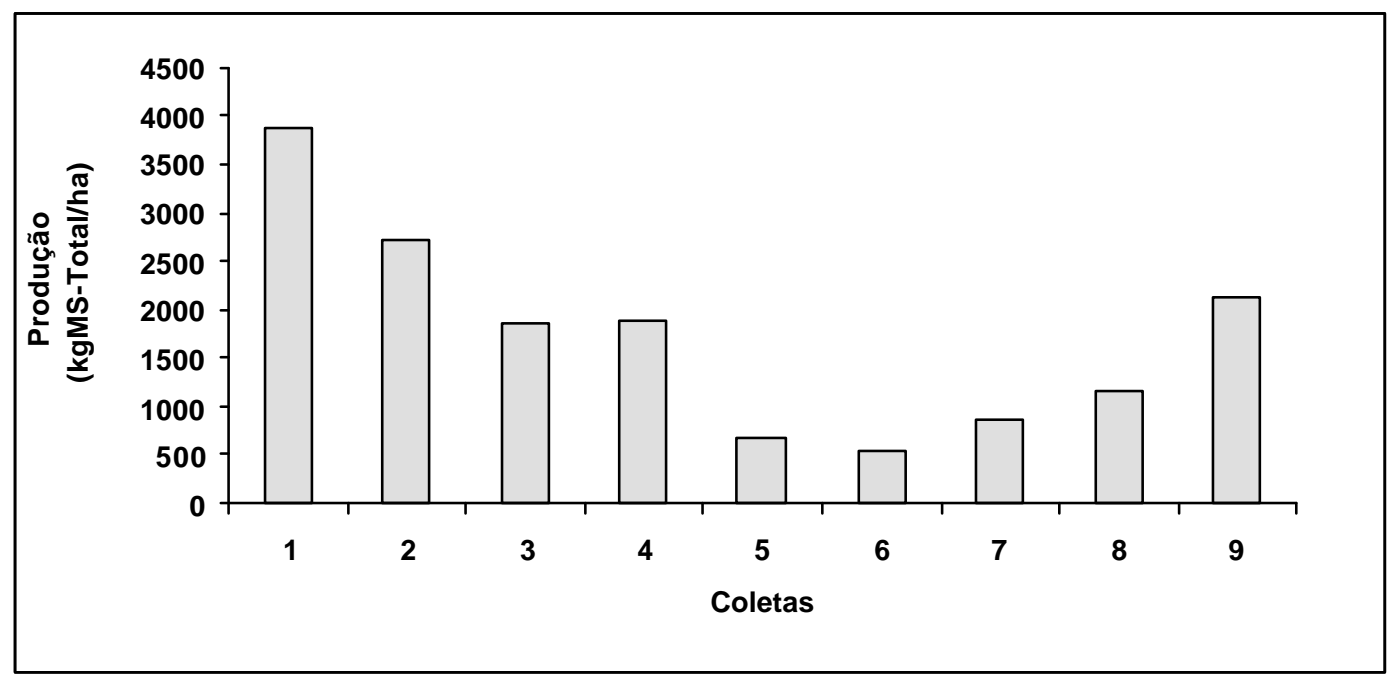

Figura 4 - Média de produção de massa seca total $\left(\mathrm{kg} \mathrm{MS.ha}^{-1}\right)$ por período de coleta, em pastagem de capim-Tanzânia estabelecido numa Terra Roxa Estruturada, avaliados na Fazenda Areão, Piracicaba, SP.

Rolim (1994) comenta que as baixas temperaturas noturnas nas regiões do trópicos e subtrópicos seriam os principais agentes causadores da estacionalidade em capins do gênero Panicum. Estas regiões tendem a apresentar como característica elevados índices de radiação global recebida, mesmo nos períodos menos favoráveis ao desenvolvimento do Panicum, sendo estes valores geralmente superiores a 300 cal.cm ${ }^{-2}$ dia (Silva, 1995), podendo ser verificado na Figura 3.

Os menores valores de radiação global (282 - 390 cal.cm ${ }^{-2}$ dia) e temperatura mínima (11 a $13{ }^{\circ} \mathrm{C}$ ) ocorreram entre o meses de maio a agosto (Figura 2 a 3), o que fez com que os valores de evapotranspiração da planta também caíssem para aproximadamente 2,5 mm.dia ${ }^{-1}$, reduzindo assim a produção de massa seca do capim (Figura 4). A associação destes fatores, acabou por afetar as plantas direta ou indiretamente nos seus processos fisiológicos, e nos processos de absorção e translocação de nutrientes, respectivamente (Silva, 1995).

A ocorrência da estacionalidade na produção de massa seca em Piracicaba (Figura 4), afetada pelos parâmetros climáticos, é algo característico da região em 
estudo, sendo assim, o efeito da irrigação (Tabela 9 e 10), como manejo complementar no inverno para aumentar a produção do capim-Tanzânia, não foi significativo nesse período, por outro lado, durante os períodos de verão e primavera, só houve "déficit" hídrico significativo no solo no quarto período de corte (resposta significativa), nos demais períodos desse ano agrícola as chuvas foram bem distribuidas; somente um experimento conduzido em condições de ambiente protegido, poderia mostrar o efeito do "déficit" hídrico na produção de massa seca nesses períodos mais favoráveis de temperatura e luminosidade .

Ghelfi Filho (1972) em cultivo de capim elefante Napier irrigado em PiracicabaSP , somente no inverno, obteve aumento de apenas $5 \%$ na produção anual total. Pedreira (1973) mostrou em um estudo de 5 anos que o capim-Colonião cultivado em Nova Odessa - SP apresentava como distribuição porcentual da produção anual, concentração de $90 \%$ de sua produção de massa seca no período do verão, e somente 10 $\%$ no inverno.

Comparando-se as variação dos valores de precipitações mensais durante o período experimental com a média dos valores entre 1917 a 2001, observa-se que os valores de precipitação durante a condução do experimento mostraram-se inferiores a sua média histórica (Figura 5), porém sem "déficit" hídrico significativo no solo mesmo nessa condição de precipitação inferior. Considerando somente a precipitação, a presença de uma pluviosidade menor entre os meses de maio a agosto, poderia permitir considerar a existência de condições propícias (considerando aqui também os outros fatores climáticos) para o desenvolvimento deste experimento em campo, e assim fazer a identificação de efeitos significativos neste estudos, no uso diferenciado de lâminas de irrigação na produção do capim-Tanzânia, portanto, outro fator influiu no desenvolvimento do capim-Tanzânia e no não efeito do uso das lâmina de irrigação. 


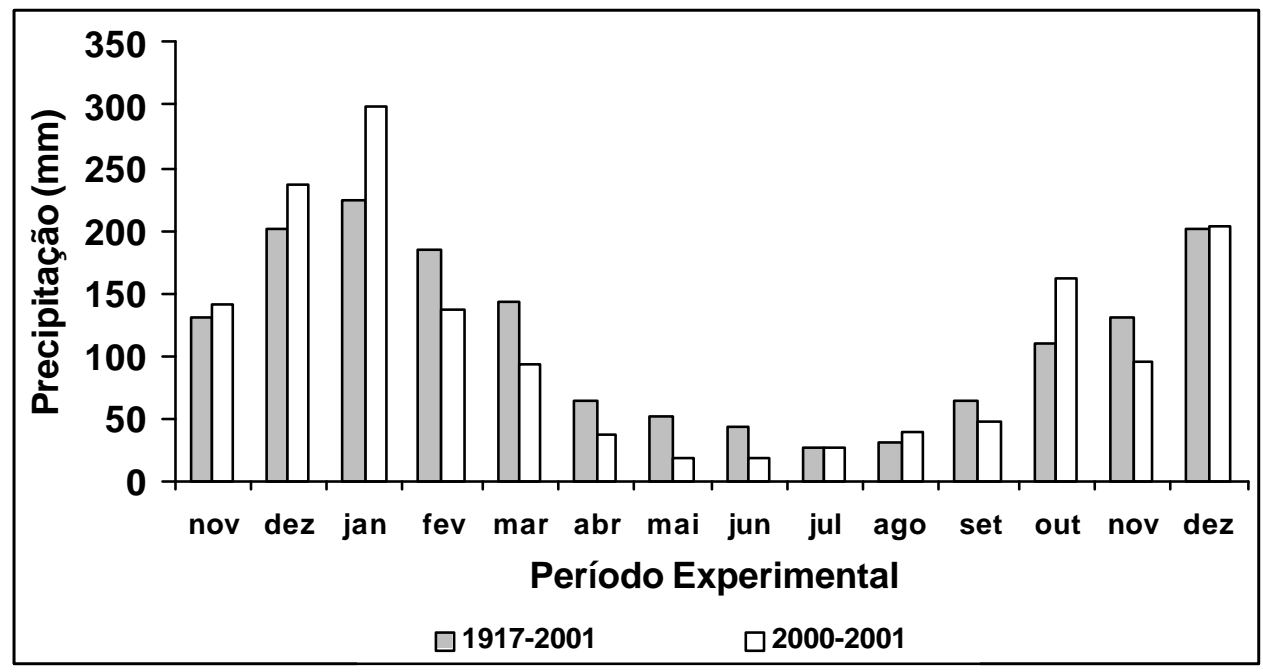

Figura 5 - Comparação de precipitações em área de pastagem de capim Tanzânia e dados climatológicos entre 1917-2001, em Piracicaba,SP.

Vázquez (1965), estudando o efeito da irrigação e nitrogênio na produção de Panicum maximum e outras gramíneas, verificou efeito sazonal do consumo de uso de água e produção de forragem. Quando considerado somente o período frio e seco não foram encontrados efeitos do uso de irrigação na produção do Panicum maximum, concluindo que o consumo representativo de água pelo capim seria aquele suprido pelo armazenamento de água no solo na parcela experimental. Isto mostraria a importância de considerarmos as características físicas do solo (textura, estrutura e outros) no seu armazenamento de água para a planta.

\subsubsection{Variação de Água no Solo}

A variação diária do potencial matricial (bar) de água no solo, controlado pelos tensiômetros digital de punção, em diferentes profundidades até $100 \mathrm{~cm}$, durante todo período experimental na lâmina controle $(100 \% \mathrm{CC})$, e os balanços hídricos para variação anual da seqüência de excedentes e deficiências hídricas no solo, e de precipitação e evapotranspiração (Real e Potencial) para três momentos distintos 
estudados: a) ano 2001 , b) média dos anos de 1917 - 2001 e c) ano de 2001, na parcela irrigada mantida na capacidade de campo $(100 \%$ CC), são mostrados nas Figuras de 6 a 8. Em todos os casos, considerou-se a real capacidade de armazenamento de água inicial disponível no solo (CAD) de $32 \mathrm{~mm}$, calculada para a profundidade de 0 a $40 \mathrm{~cm}$

As maiores variações de potenciais mátricos observadas ocorreram superficialmente no solo entre as camada de 20 a $40 \mathrm{~cm}$ de profundidade (Figura 6). Esta maior variabilidade, poderia ser explicada pela presença de $87 \%$ de todo o sistema radicular desta gramínea, nesta camada de solo explorado (Figura 1). Os valores de potenciais mantiveram-se próximos do limite máximo de 0,30 bar, com a presença de momentos pontuais próximos a 0,50 bar, que seria explicado quando do momento de retirada dos tubos gotejadores da área para o corte e entrada de animais .

Com o objetivo de iniciar-se a irrigação sempre que os valores de potencial no solo superavam a 0,20 bar, o método de tensiometria de punção, mostrou-se bastante eficiente e prática para o monitoramento da água no solo. Lima (1999), comenta que o uso do tensiômetro mostra-se adequado ao monitoramento da irrigação, respondendo perfeitamente às questões "quando irrigar" e "quanto irrigar".

Observa-se em dois momentos no trabalho, coletas 4 e 6 a 7, aumento nos potenciais acima de 0,20 bar nas profundidades abaixo de $40 \mathrm{~cm}$. Este aumento deve-se primeiramente a presença de período sem precipitação (mais de 2 semanas) (coleta 4), e devido ao período de "déficit" hídrico característico na região, onde mesmo com o uso da lâmina necessária para elevar a capacidade de campo, pode-se observar ainda a existência de "déficit" hídrico no solo (coletas 6 a 7)( Figuras 7 e 8). 

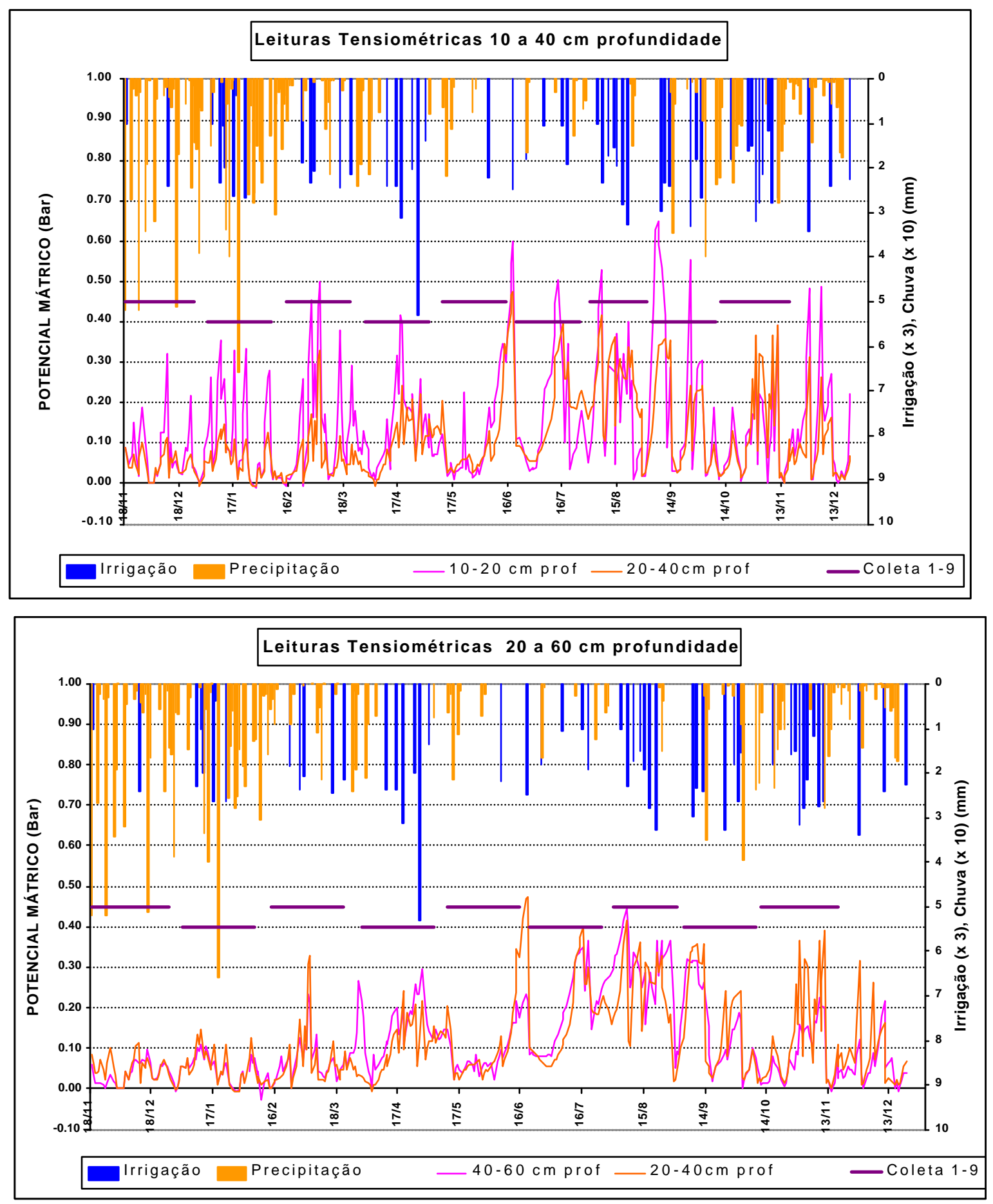

Figura 6 - Variação diária de potencial mátrico (Bar) em duas profundidades no solo, através da tensiometria, em uma área de pastagem com capim-Tanzânia, em Piracicaba, SP. 

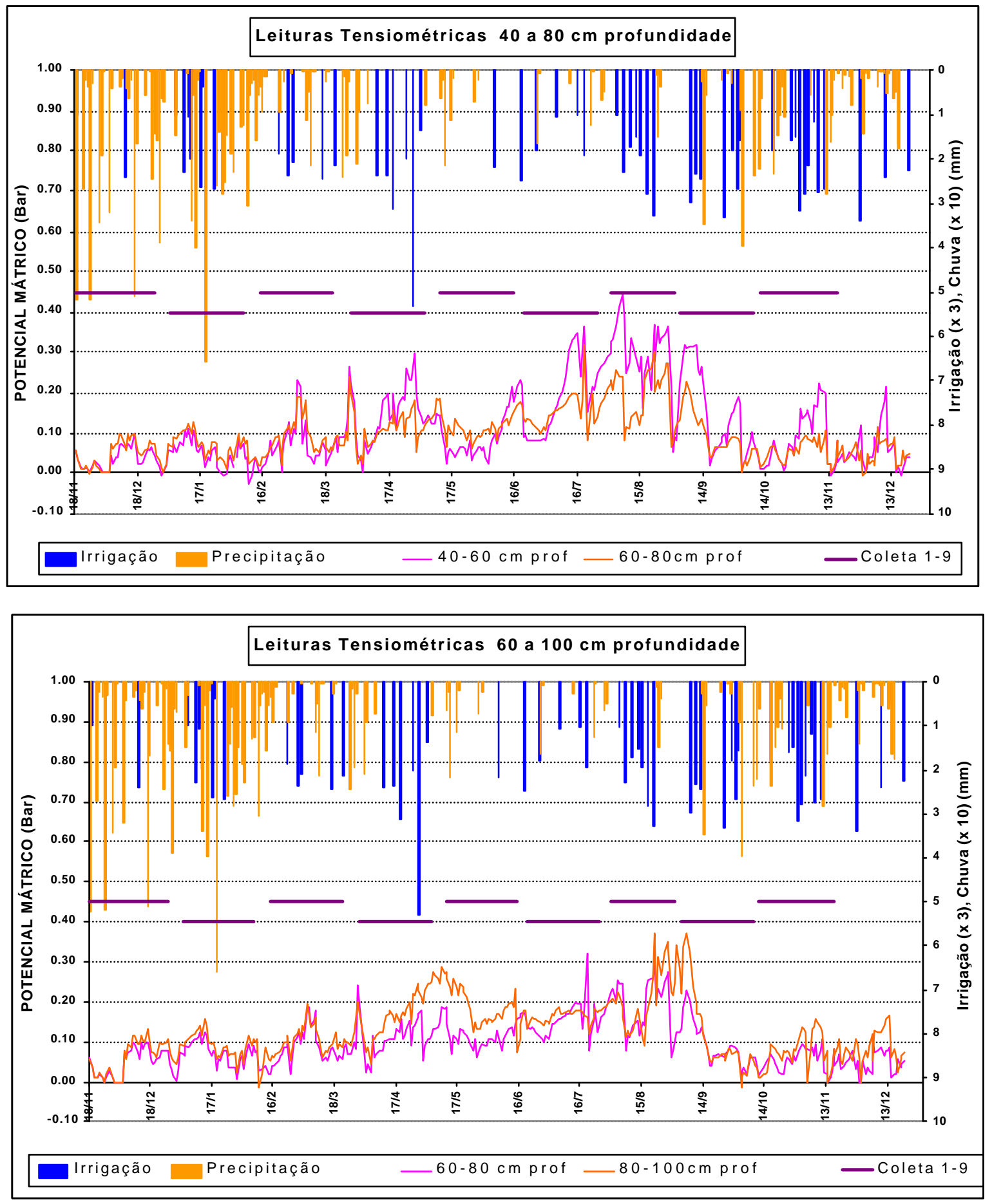

Figura 7 - Variação diária de potencial mátrico (Bar) em duas profundidades no solo, através da tensiometria, de uma área de pastagem com capim-Tanzânia, em Piracicaba, SP. 

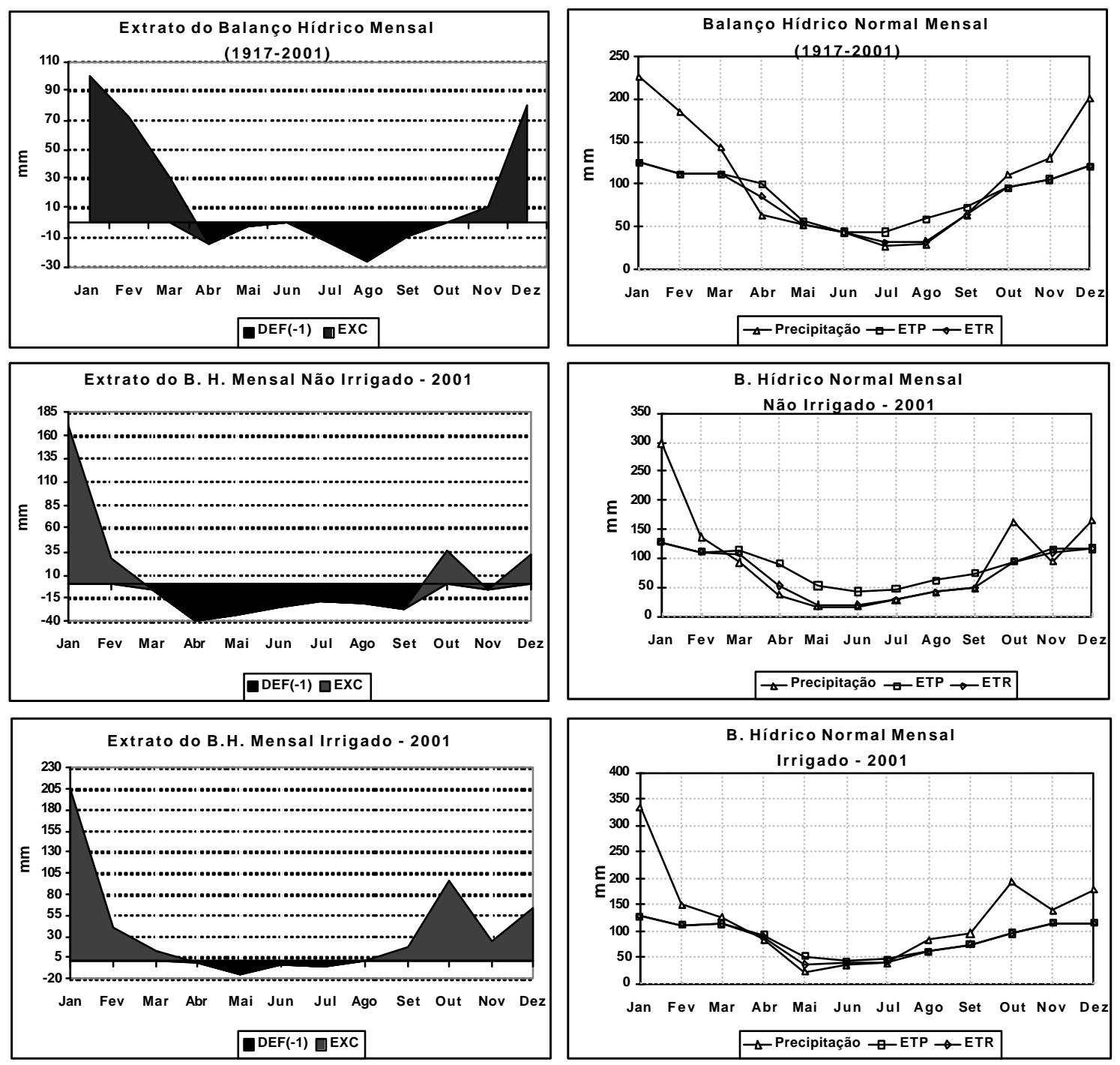

Figura 8 - Representação simplificada de balanço hídrico para variação anual da sequiência de excedentes e deficiências hídricas no solo, e de precipitação e evapotranspiração (Potencial e Real ) durante três momentos (2001, 1917 a 2001 e 2001 mantida na capacidade de campo (CC)), em área de pastagem com capim-Tanzânia, em Piracicaba, SP. 
Com a ocorrência de temperaturas altas na quarta coleta (Figura 2), o desenvolvimento do capim-Tanzânia foi favorecido, o que necessitou de maior número de irrigações, necessárias para o controle do potencial matricial no solo próximo a 0,20 bar (Figura 6 ). As outras coletas (6 e 7) apresentaram aumento de necessidade de irrigação também a partir do aumento dos valores de temperatura médias mínima.

Estes dois momentos mostram um secamento em profundidade, possivelmente devido à uma percolação da água do solo e também em parte com a participação da absorção radicular (11 \% das raízes abaixo de $60 \mathrm{~cm}$ ). Durante o resto do ano, os valores de potenciais ficaram sempre próximos a capacidade de campo (0,10 bar) (Figura 7).

O balanço hídrico climatológico usado foi aquele desenvolvido por Thornthwaite \& Mather (1955), citado e utilizado por Rolim et al. (1998) para o desenvolvimento da planilha BHNorm, a qual visa o conhecimento das condições do balanço de água no solo coberto por uma vegetação padrão (grama-Batatais - Paspalum notatum Flüggé).

Pode-se observar que durante o ano de 2001, o período de "déficit" hídrico mostrou-se maior do que a média de 94 anos, quando se considerou somente a precipitação. Somando-se a precipitação à lâmina de irrigação usada para deixar o solo em sua capacidade de campo, pode-se observar ainda a presença de pequeno "déficit" hídrico, pela incapacidade de acionamento da irrigação em tempo real da necessidade.

A variação de volume nos balanços hídricos $(\triangle \mathrm{BH}=\mathrm{EXC}-\mathrm{DEF})$ para os três períodos estudados, foram de $227 \mathrm{~mm}$ para a média de 94 anos, e de 432 e $90 \mathrm{~mm}$ no ano de 2001, considerado somatória da irrigação a precipitação, ou não.

Os valores de evapotranspiração real (ETr) determinados pela planilha, e que indicam a evaporação que realmente está ocorrendo em função da disponibilidade de água no solo, mostraram-se inferiores aos valores de evapotranspiração potencial (ETp), quando considerado somente precipitação. Com a irrigação, os valores de $\mathrm{ETr}$ aproximaram-se aos de ETp, diferindo-se somente no período de "déficit" hídrico regional.

Pérez e Acosta (1986) estudando o uso e freqüências de irrigação em Panicum maximum e em mais quatro gramíneas, durante o período seco em Cuba, encontraram 
respostas ao uso de irrigação em suas produções. A diferença entre o controle e as parcelas irrigadas se explicariam pela variação entre os valores de precipitação (indiretamente a ETr,) e a evaporação ( transformando para ETp pela multiplicação por um $\mathrm{Kp}=0,7)$. Assim, com o aumento da ETp em relação a precipitação, observaram-se desbalanço hídrico nas plantas e com correspondente decréscimo no rendimento dos pastos.

Thornthwaite \& Mather citados por Pereira et al. (1997), descrevem que o balanço hídrico diário pode ser utilizado para o acompanhamento do armazenamento de água no solo em tempo real, isto é, no momento de sua ocorrência, de maneira a viabilizar o uso de estações climatológicas no controle da irrigação.

Com a determinação da evapotranspiração potencial diária para gramado pelo método de Penman-Monteith, fez-se uso do coeficiente de cultura - Kc (variando linearmente de 0,30 a 1,1) para a determinação da evapotranspiração potencial máxima diária possível de ocorrer no capim Tanzânia, os quais foram introduzidos em planilha de determinação de balanço hídrico conforme sugerido por Thornthwaite \& Mather (1955), para a determinação da evapotranspiração real diária possível durante o desenvolvimento do capim Tanzânia.

Os balanços hídricos diários para cada período de coleta e variação de estação de trabalho, e as variações diárias de evapotranspirações potenciais máximas (ETp) e reais (ETr) para o capim Tanzânia, determinados considerando os cinco diferentes manejos de irrigação são mostrados nas Figuras de 9 a 23.

Os valores de Coeficiente de cultura ( $\mathrm{Kc}$ ) utilizados, foram aqueles propostos por Doorenbos \& Kassam (1994) para a cultura de alfafa, diferindo daqueles encontrados por Lourenço et al. (2001) em capim-Tanzânia sob pivô central, no qual observaram valores médios de coeficiente de cultura de 0,45 após o pastejo e de 0,98 no final do ciclo de crescimento que antecederam ao novo pastejo. 

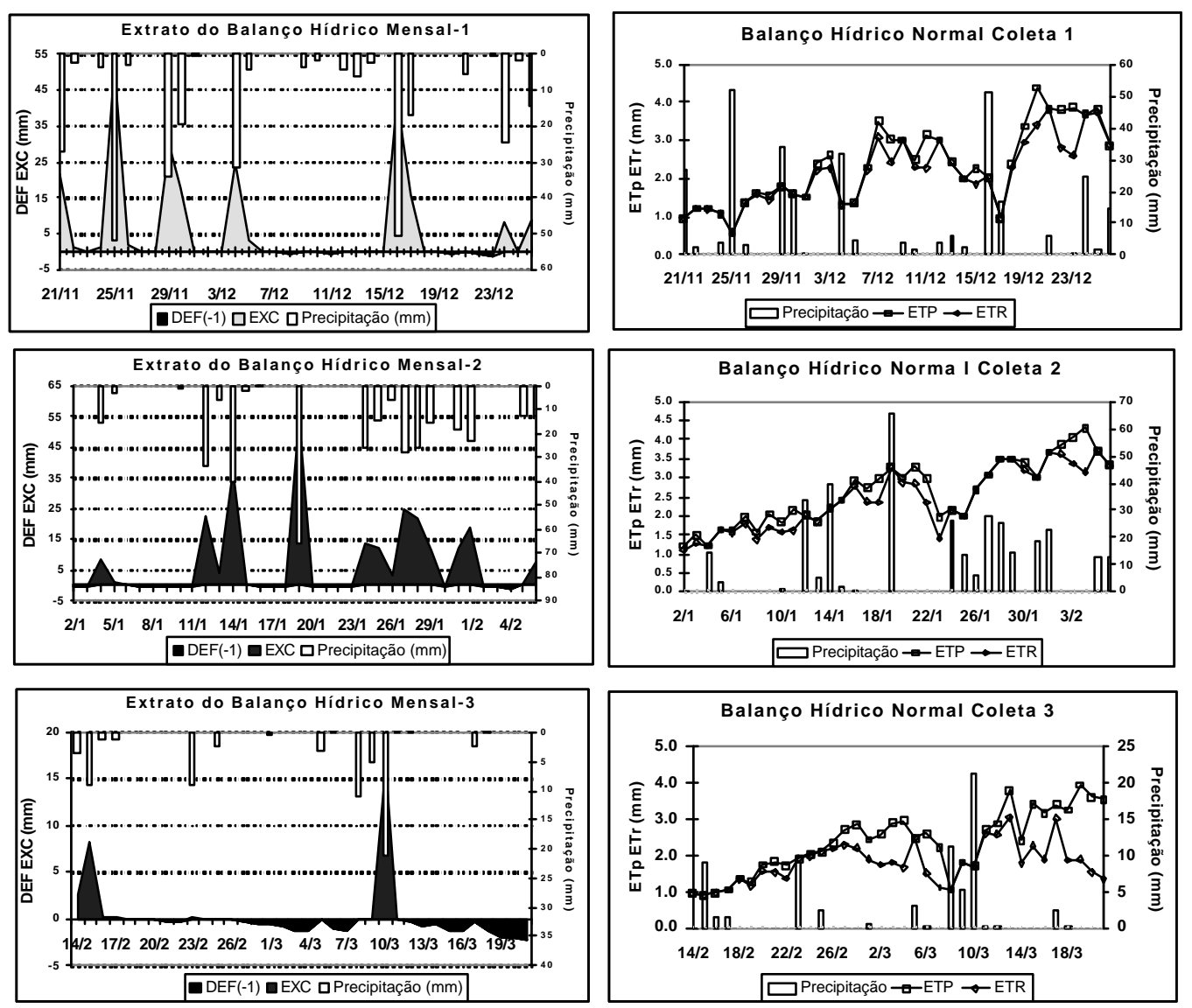

Figura 9 - $\quad$ Representação simplificada de balanço hídrico para variação na estação do verão (21/11/2000 a 21/03/2001), da seqüência de excedentes e deficiências hídricas no solo, e de precipitação e evapotranspiração (Real e Potencial) no tratamento sem irrigação (0 \% CC - somente precipitação), em área de pastagem com capim-Tanzânia, em Piracicaba, SP. 

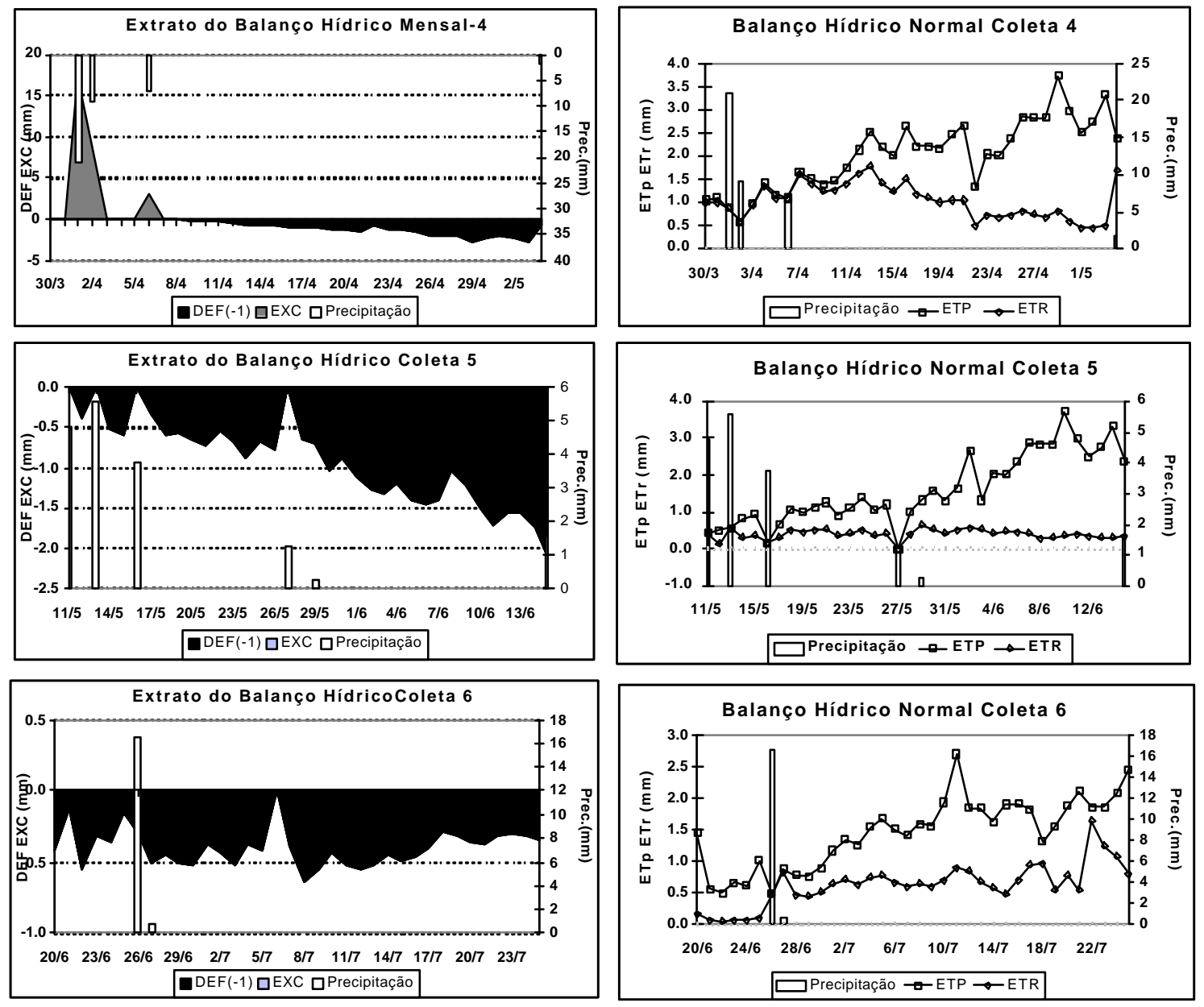

Figura 10 - Representação simplificada de balanço hídrico para variação na estação do inverno (30/03 a 25/07/2001), da seqüência de excedentes e deficiências hídricas no solo, e de precipitação e evapotranspiração (Real e Potencial) no tratamento sem irrigação (0 \% CC - somente precipitação), em área de pastagem com capim-Tanzânia, em Piracicaba, SP. 

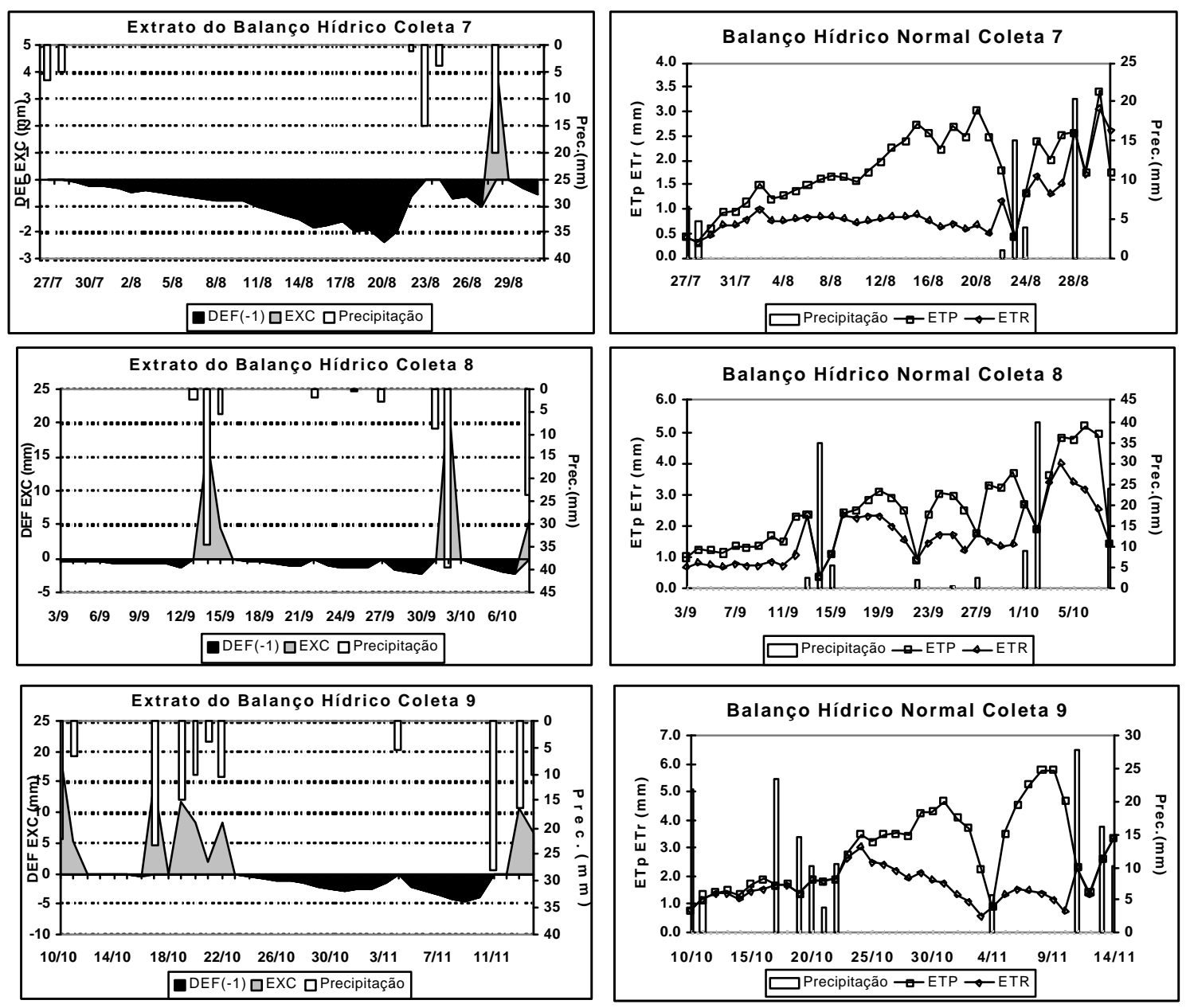

Figura 11 - Representação simplificada de balanço hídrico para variação na estação da Primavera (27/07 a 14/11/2001), da sequiência de excedentes e deficiências hídricas no solo, e de precipitação e evapotranspiração (Real e Potencial) no tratamento sem irrigação (0\% CC - somente precipitação), em área de pastagem com capim-Tanzânia, em Piracicaba, SP. 

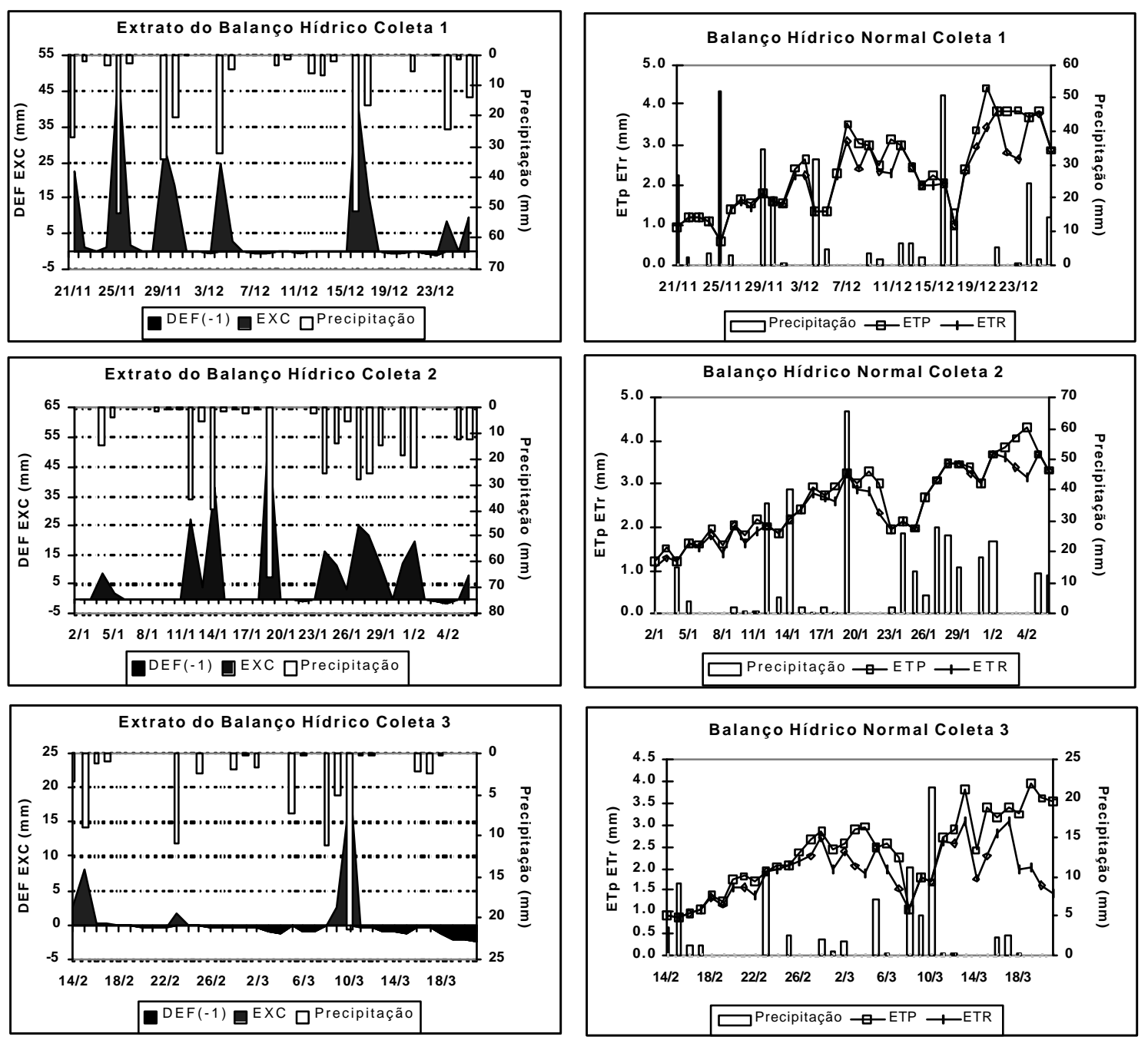

Figura 12 - Representação simplificada de balanço hídrico para variação na estação do verão (21/11/2000 a 21/03/2001), da seqüência de excedentes e deficiências hídricas no solo, e de precipitação e evapotranspiração (Real e Potencial) no tratamento de $30 \% \mathrm{CC}$, em área de pastagem com capim-Tanzânia, em Piracicaba, SP. 

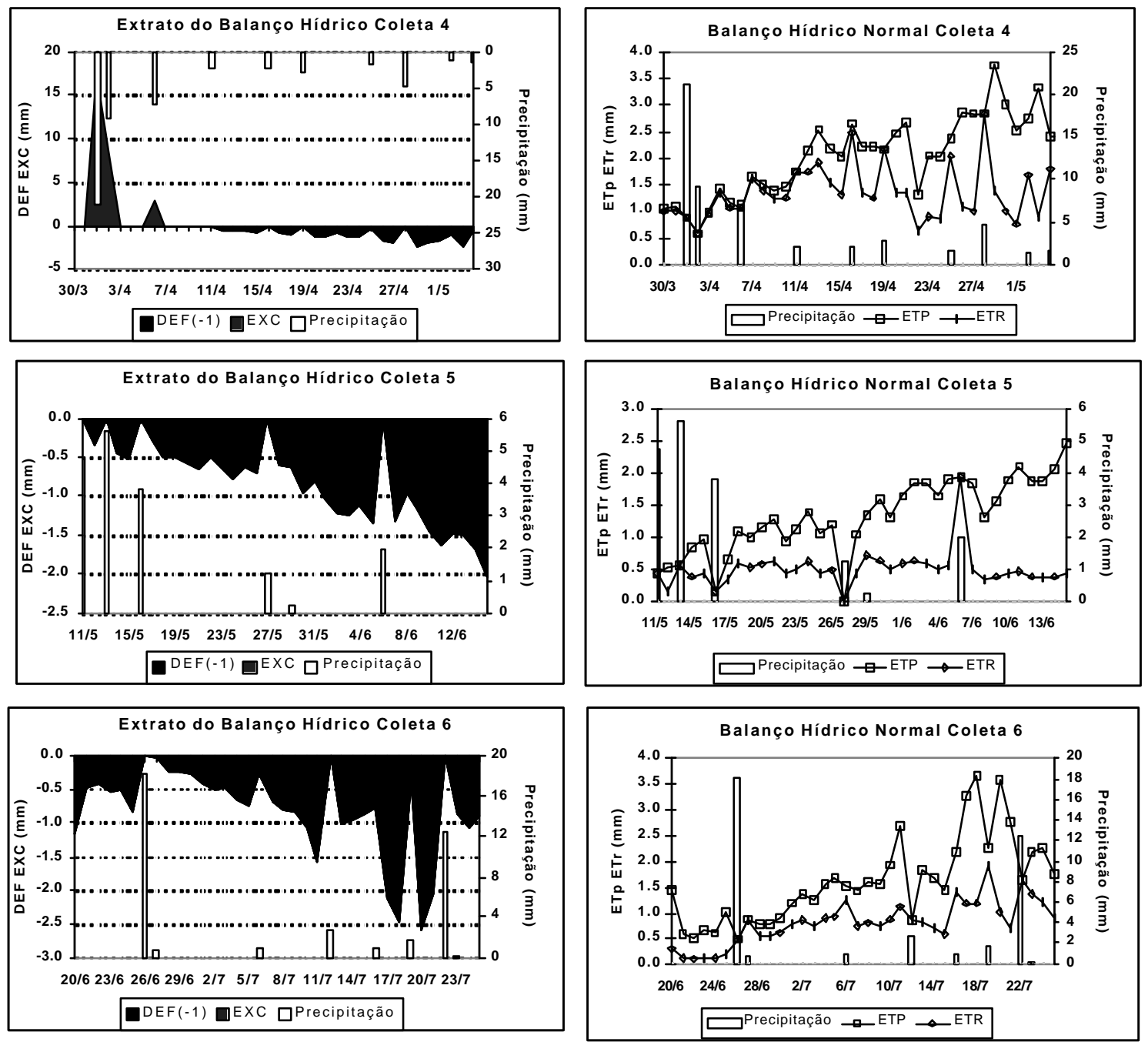

Figura 13 - Representação simplificada de balanço hídrico para variação na estação do inverno (30/03 a 25/07/2001), da seqüência de excedentes e deficiências hídricas no solo, e de precipitação e evapotranspiração (Real e Potencial) no tratamento $30 \% \mathrm{CC}$, em área de pastagem com capim-Tanzânia, em Piracicaba, SP. 

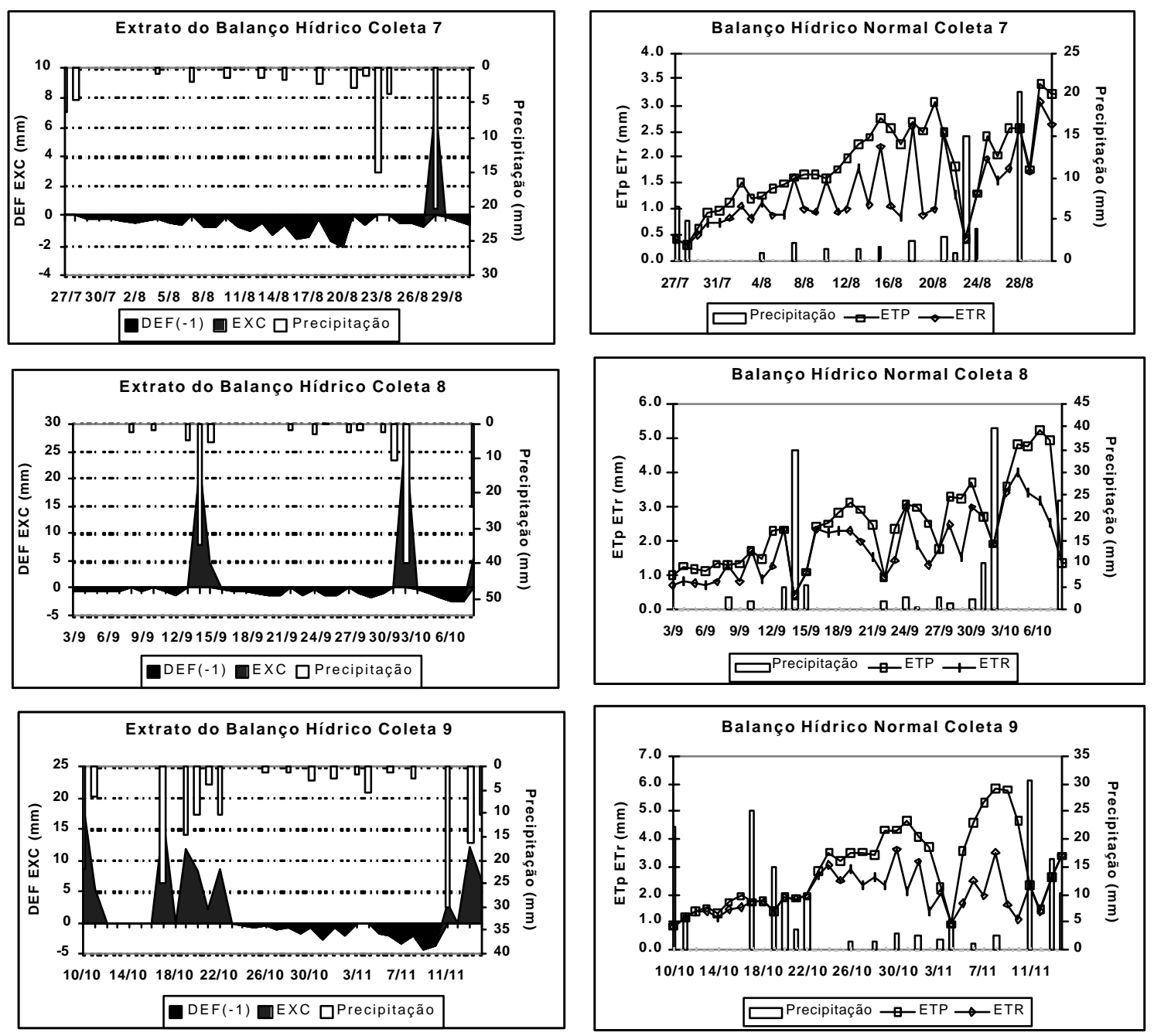

Figura 14 - Representação simplificada de balanço hídrico para variação na estação da Primavera (27/07 a 14/11/2001), da seqüência de excedentes e deficiências hídricas no solo, e de precipitação e evapotranspiração (Real e Potencial) no tratamento $30 \% \mathrm{CC}$, em área de pastagem com capim-Tanzânia, em Piracicaba, SP. 

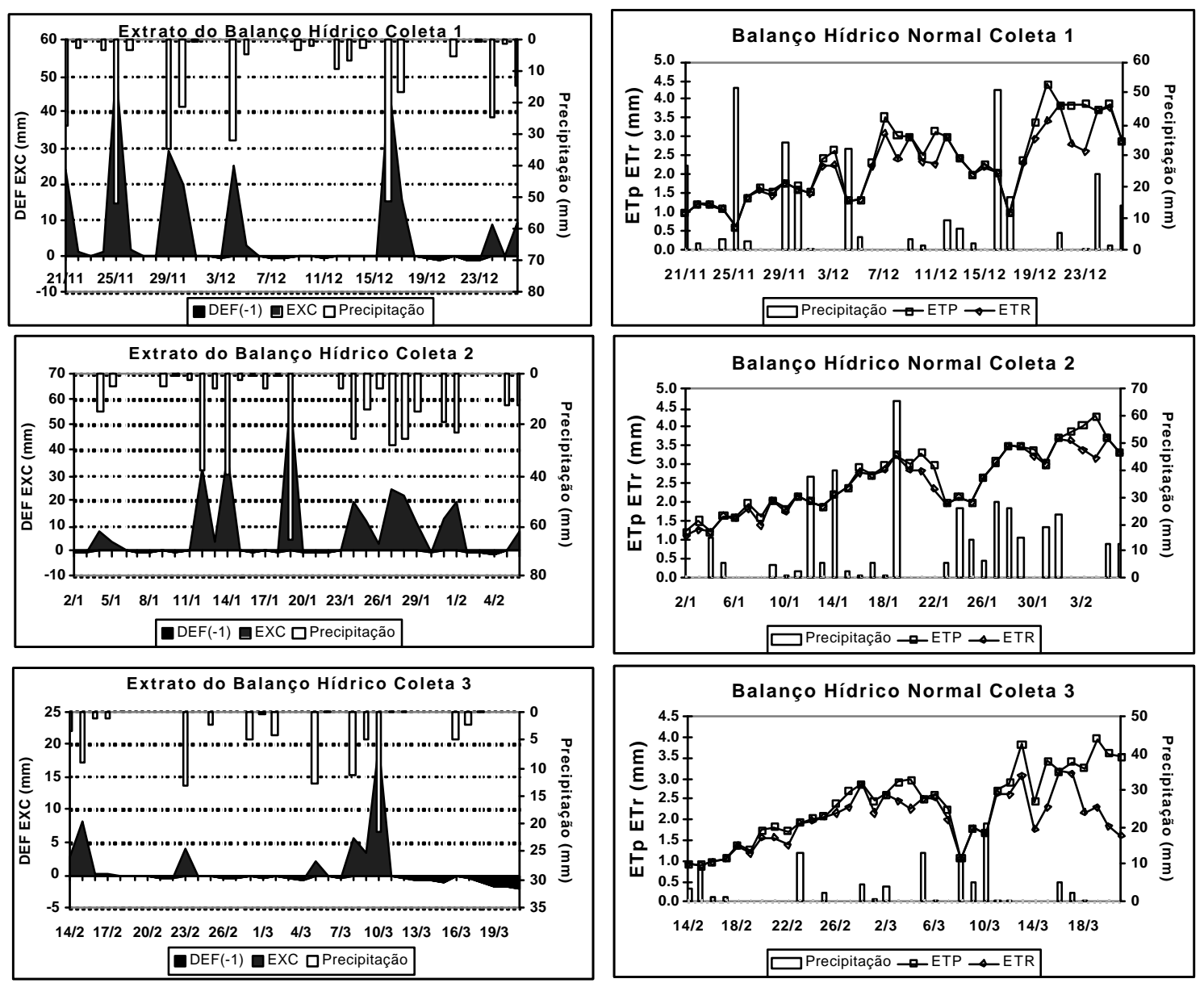

Figura 15 - Representação simplificada de balanço hídrico para variação na estação do verão (21/11/2000 a 21/03/2001), da sequiência de excedentes e deficiências hídricas no solo, e de precipitação e evapotranspiração (Real e Potencial) no tratamento de $70 \% \mathrm{CC}$, em área de pastagem com capim-Tanzânia, em Piracicaba, SP. 

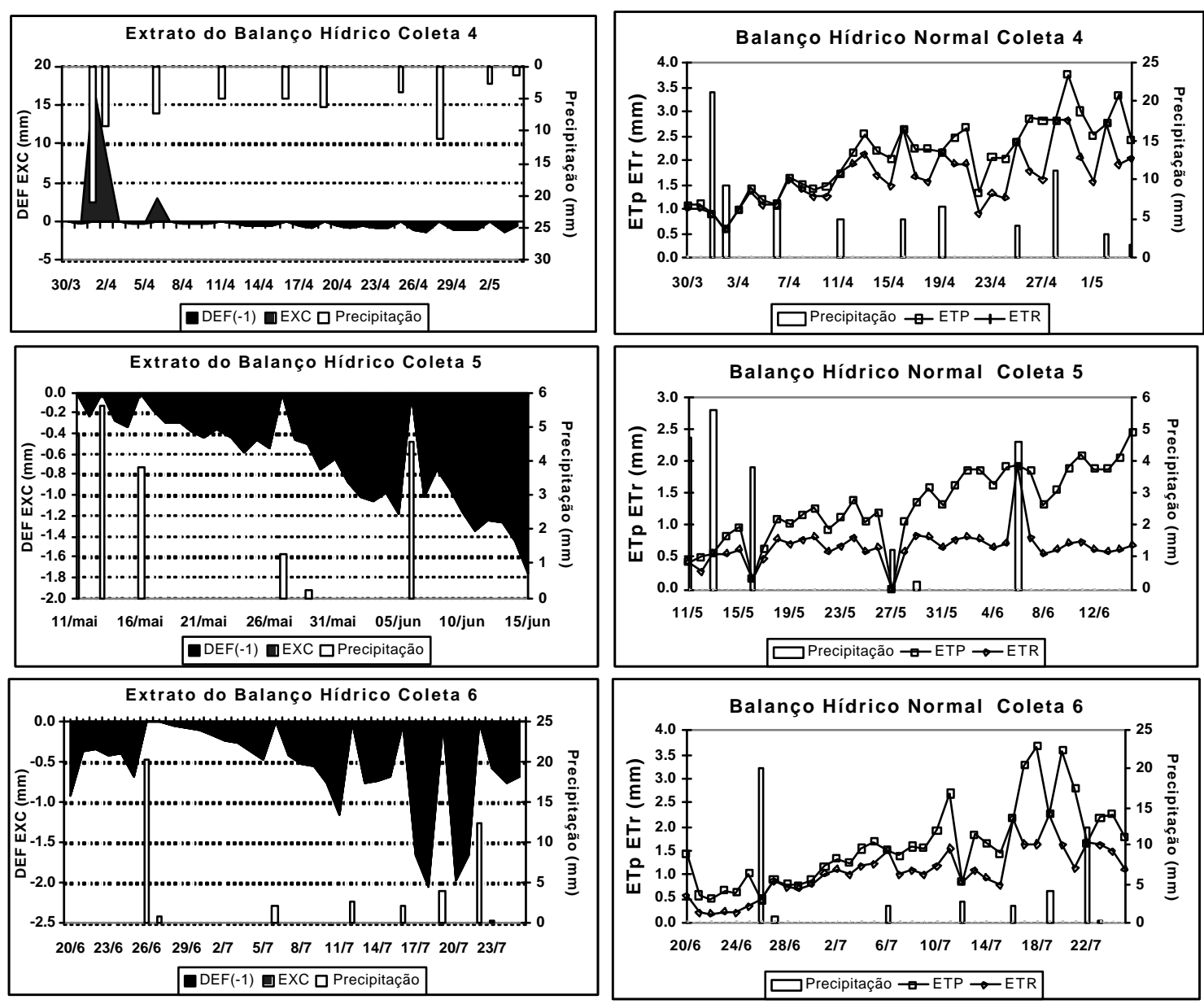

Figura 16 - Representação simplificada de balanço hídrico para variação na estação do inverno (30/03 a 25/07/2001), da seqüência de excedentes e deficiências hídricas no solo, e de precipitação e evapotranspiração (Real e Potencial) no tratamento $70 \% \mathrm{CC}$, em área de pastagem com capim-Tanzânia, em Piracicaba, SP. 

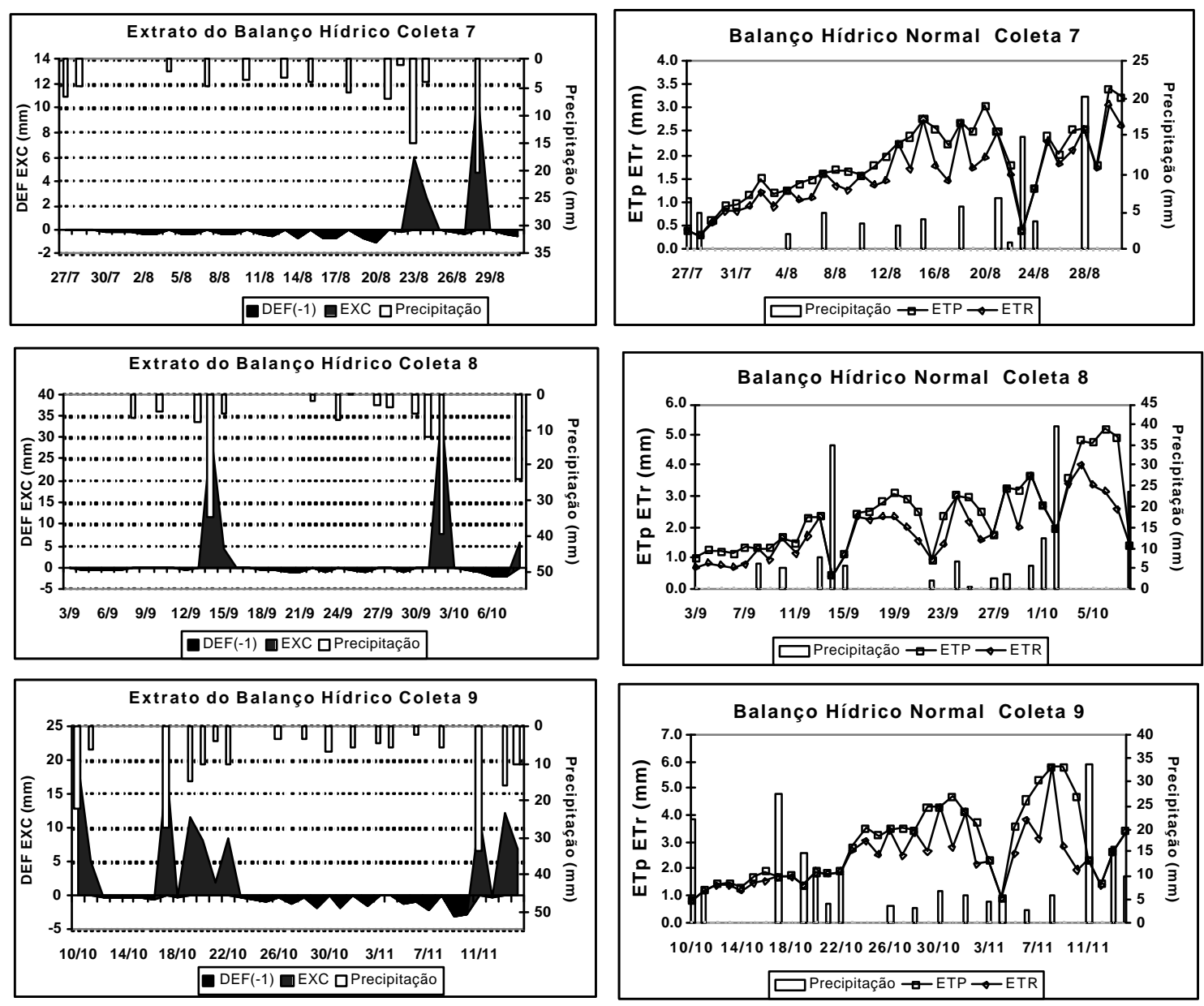

Figura 17 - Representação simplificada de balanço hídrico para variação na estação da Primavera (27/07 a 14/11/2001), da seqüência de excedentes e deficiências hídricas no solo, e de precipitação e evapotranspiração (Real e Potencial) no tratamento $70 \% \mathrm{CC}$, em área de pastagem com capim-Tanzânia, em Piracicaba, SP. 

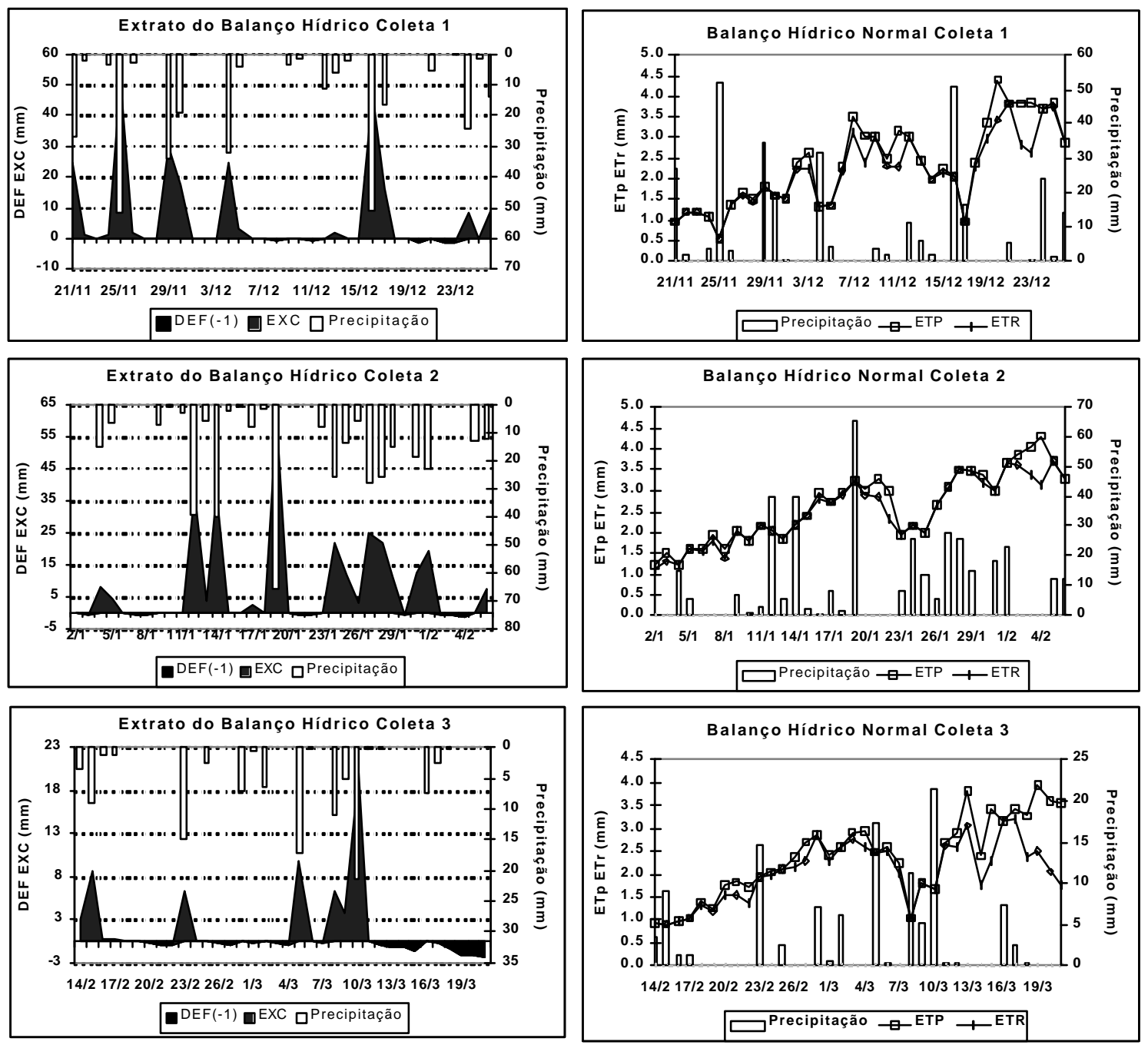

Figura 18 - Representação simplificada de balanço hídrico para variação na estação do verão (21/11/2000 a 21/03/2001), da sequiência de excedentes e deficiências hídricas no solo, e de precipitação e evapotranspiração (Real e Potencial) no tratamento $100 \%$ CC, em área de pastagem com capim-Tanzânia, em Piracicaba, SP. 

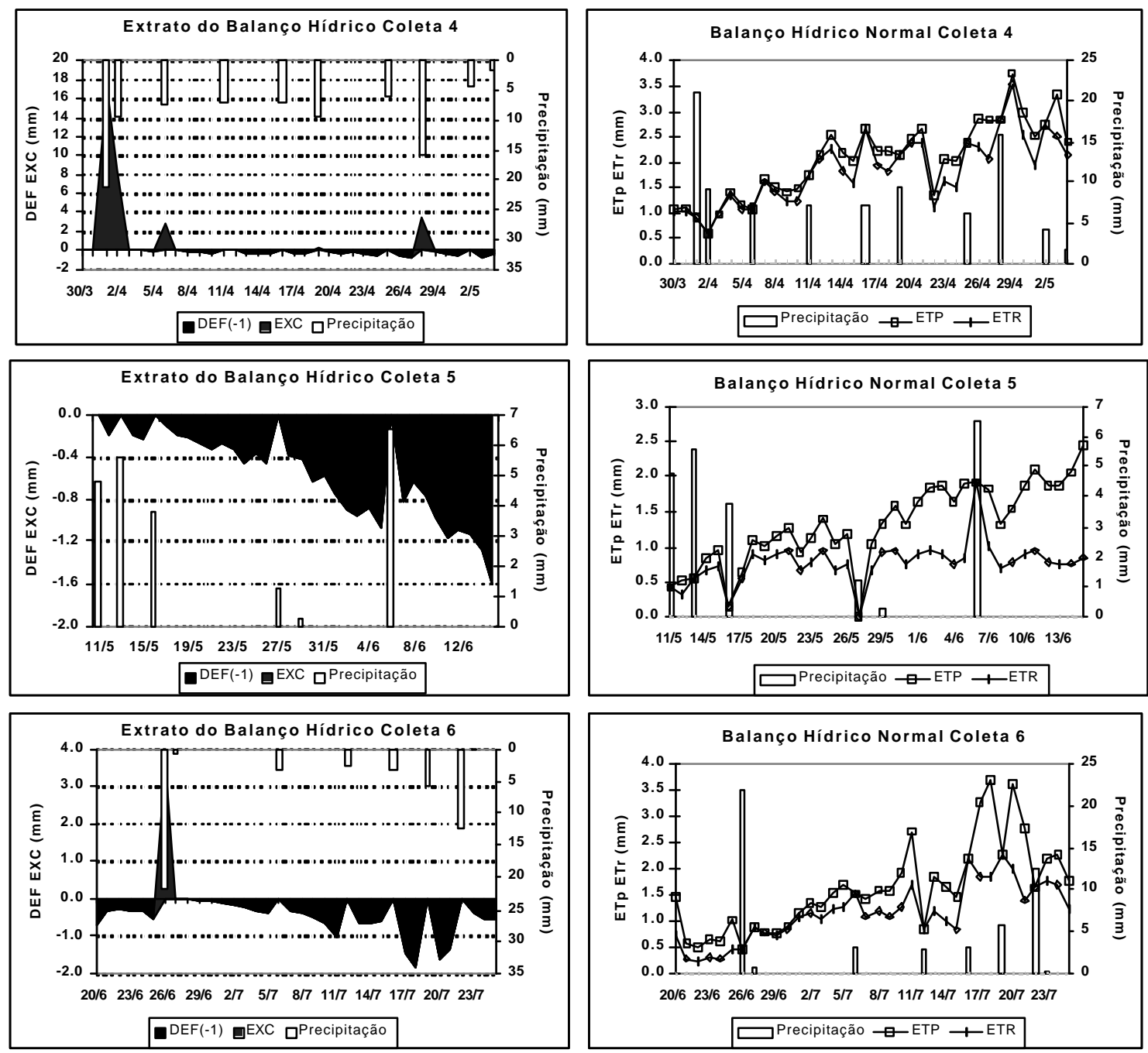

Figura 19 - Representação simplificada de balanço hídrico para variação na estação do inverno (30/03 a 25/07/2001), da seqüiência de excedentes e deficiências hídricas no solo, e de precipitação e evapotranspiração (Real e Potencial) no tratamento $100 \% \mathrm{CC}$, em área de pastagem com capim-Tanzânia, em Piracicaba, SP. 

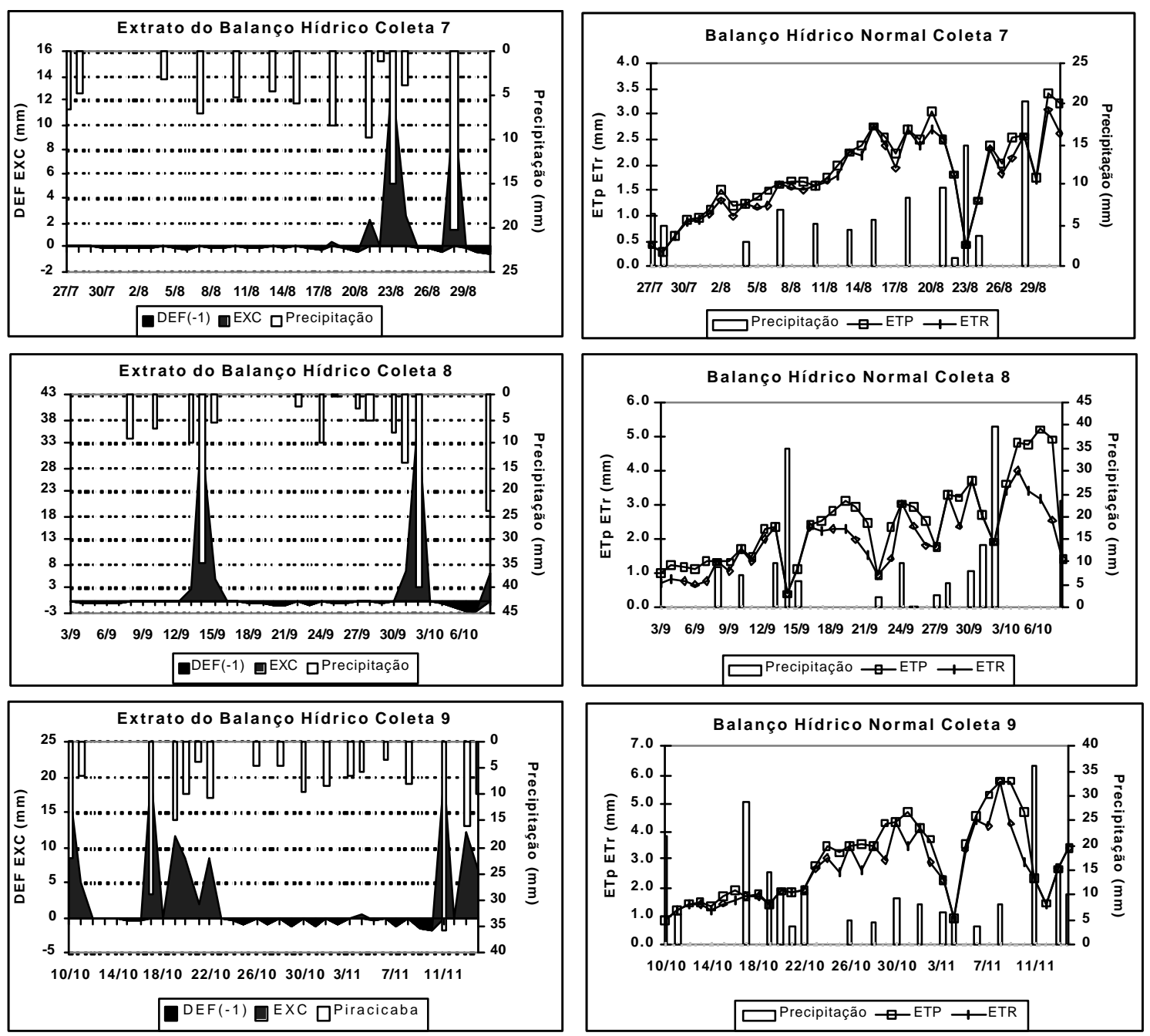

Figura 20 - Representação simplificada de balanço hídrico para variação na estação da Primavera (27/07 a 14/11/2001), da seqüência de excedentes e deficiências hídricas no solo, e de precipitação e evapotranspiração (Real e Potencial) no tratamento $100 \% \mathrm{CC}$, em área de pastagem com capim-Tanzânia, em Piracicaba, SP. 

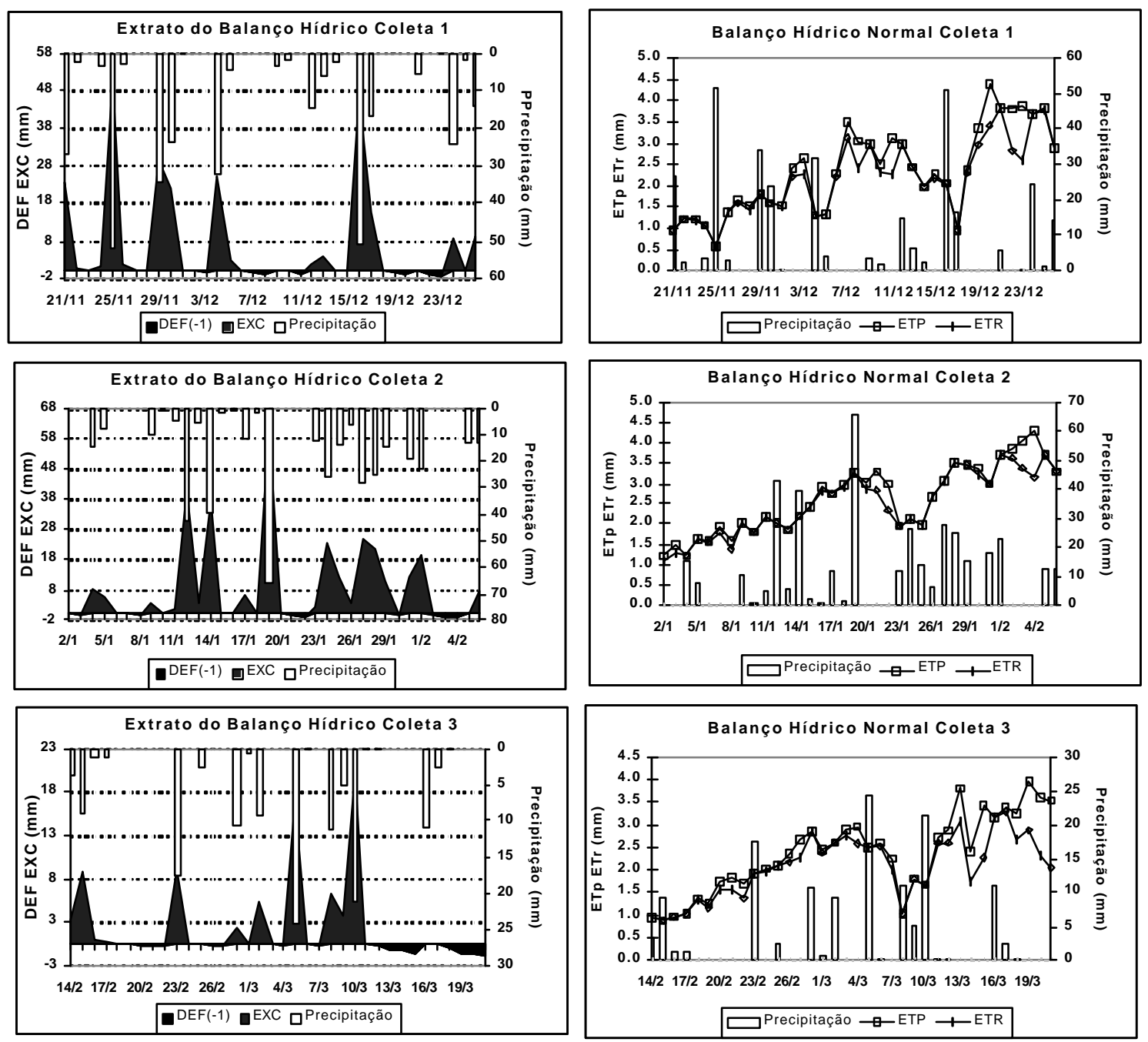

Figura 21 - Representação simplificada de balanço hídrico para variação na estação do verão (21/11/2000 a 21/03/2001), da seqüência de excedentes e deficiências hídricas no solo, e de precipitação e evapotranspiração (Real e Potencial) no tratamento $150 \% \mathrm{CC}$, em área de pastagem com capim-Tanzânia, em Piracicaba, SP. 

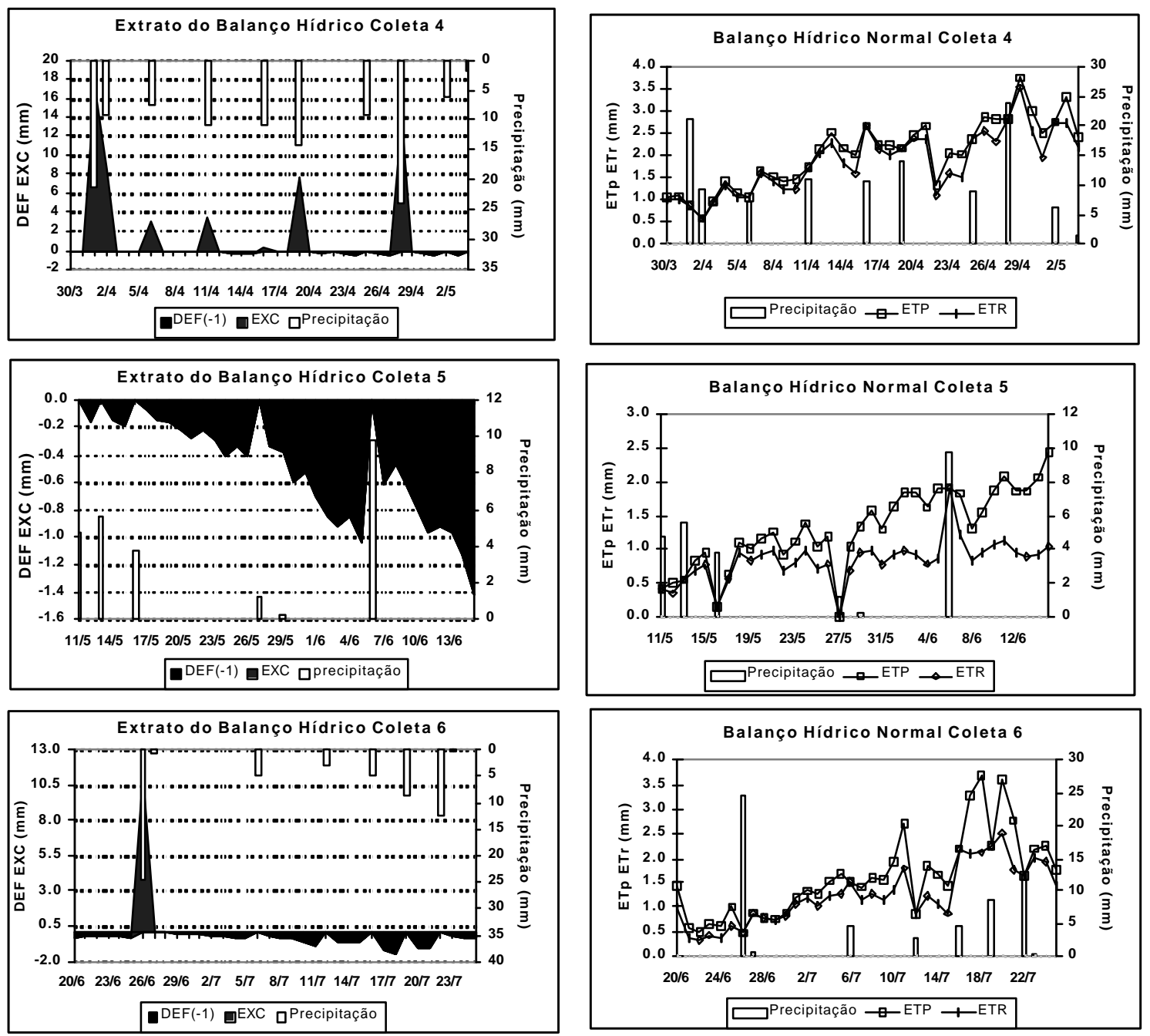

Figura 22. - Representação simplificada de balanço hídrico para variação na estação do inverno (30/03 a 25/07/2001), da sequiência de excedentes e deficiências hídricas no solo, e de precipitação e evapotranspiração (Real e Potencial) no tratamento $150 \% \mathrm{CC}$, em área de pastagem com capim-Tanzânia, em Piracicaba, SP. 

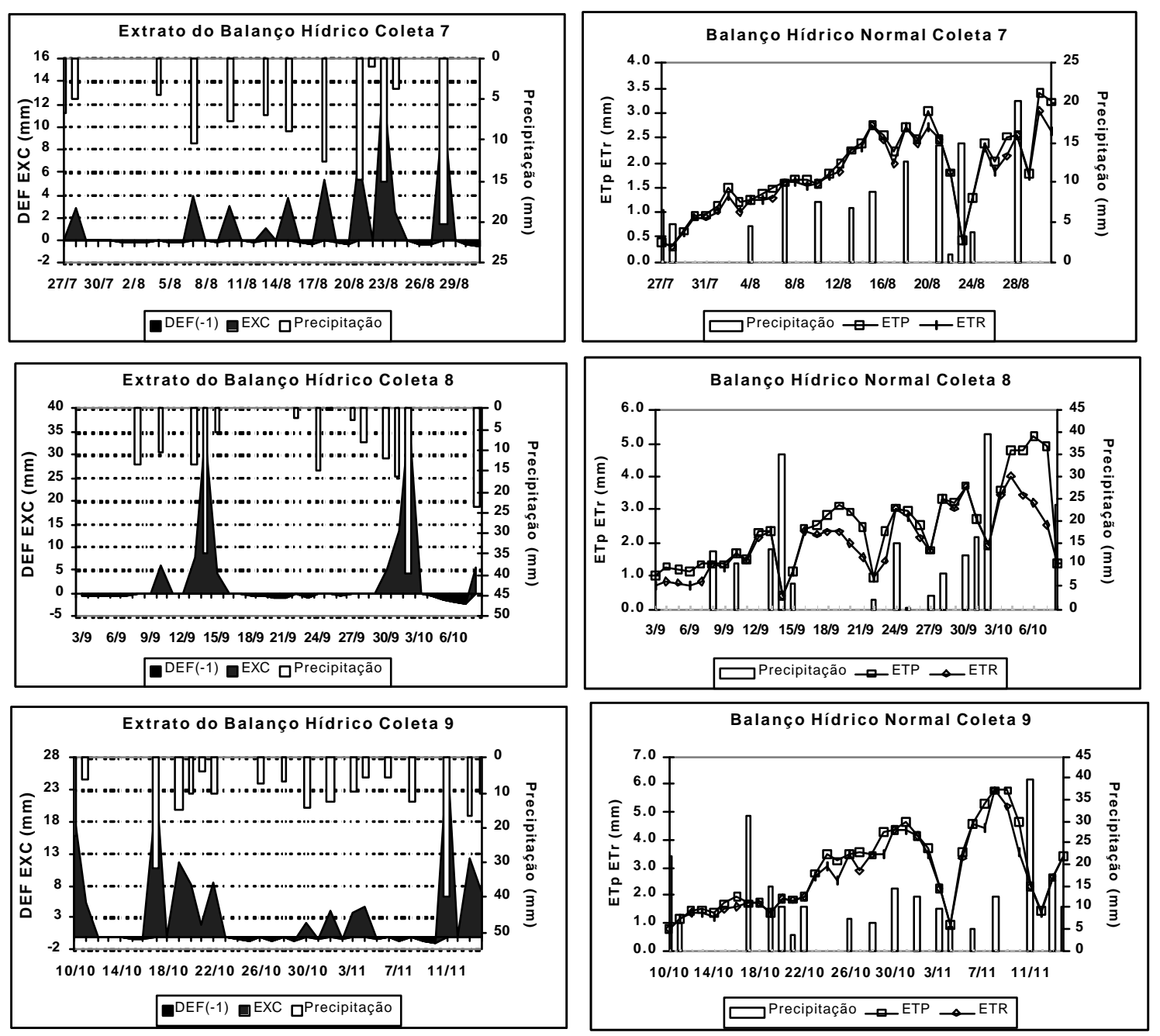

Figura 23 - Representação simplificada de balanço hídrico para variação na estação da Primavera (27/07 a 14/11/2001), da seqüência de excedentes e deficiências hídricas no solo, e de precipitação e evapotranspiração (Real e Potencial) no tratamento $150 \% \mathrm{CC}$, em área de pastagem com capim-Tanzânia, em Piracicaba, SP. 
Considerando os comportamentos dos diferentes balanços hídricos apresentados nas Figuras 9 a 23, pode-se mencionar que as coletas 5 e 6 durante a estação do inverno estão períodos sujeitas à ocorrência de "déficit" hídrico em Piracicaba, mesmo considerados os diferentes manejos de lâminas de irrigação usadas, e que poderia ser correlacionado a variação de potencial mátrico no solo (Figura 6 e 7).

Fatores climáticos como temperatura e fotoperíodo, mostram-se como fatores restritivos ao crescimento de gramíneas em geral durante o inverno, e de maneira significativa para o capim-Tanzânia, como mostrado por Pinheiro (2002), afetando a redução das produções como o início do período frio.

Com a diminuição do crescimento e da área foliar ocasionados pelo frio, as exigências de água pela cultura diminuem devido a dois fatores, um de ordem fisiológica (queda da transpiração, absorção e translocação de água pela planta) e outro devido a diminuição de demanda evaporativa da atmosfera que afetam a transpiração das plantas (Bergamaschi, 1999), que por sua vez afetam de maneira direta os valores de evapotranspiração .

O modelo de balanço hídrico no período do inverno, sugere que mesmo o capim apresentando condições de evapotranspirações potenciais (ETp) aumentando ao longo do período de corte (valores de Kc crescentes), os menores valores de evapotranspiração real (ETr) encontrados seriam mais a consequiência direta da diminuição de água disponível no solo, considerando a CAD com $32 \mathrm{~mm}$ à profundidade até $40 \mathrm{~cm}$, do que devido ao efeito maior de demanda evaporativa da atmosfera. As perdas por drenagem profunda passariam a ser insignificantes neste período.

Com a redução das precipitações e dos valores de evapotranspiração potenciais neste período, tem-se por suas diferenças alteração do armazenamento inicial de água no solo e de forma constante, tornando-o menor e afetando o desenvolvimento da gramínea. Este afastamento entre valores de ETr da ETp, tem como consequiência prejuízo ao crescimento e desenvolvimento das plantas, uma vez que com o secamento do solo a água retém-se mais firmemente ao solo (Pereira et al. 1997)

$\mathrm{Na}$ coleta quatro foi o único momento em todo período experimental que efeitos de lâmina de irrigação foram encontrados, onde associação de uma demanda evaporativa 
da atmosfera alta (causadas por altas temperaturas ainda), baixa precipitação e possibilidade de secamento do perfil em maiores profundidades, permitiram maior resposta com ao uso de irrigação. Nas Figuras 10, 13, 16, 19 e 22, observa-se que com o uso de irrigação, o modelo de balanço hídrico sugere aumento nos valores de evapotranspiração real (ETr), de modo a aproximarem-se muito da evapotranspiração real (ETp), a partir do uso de manejo de irrigação a $70 \%$ da capacidade de campo. O que é comprovado pelos resultados experimentais no Tabela 9, quanto aos efeitos das diferentes lâminas na produção de massa seca total.

O modelo de balanço hídrico sugere que, um manejo de irrigação mantendo o solo sempre a $70 \%$ da sua capacidade de campo, seria o mais indicado para uso no manejo de pastagens irrigadas, porque possibilitariam evapotranspirações reais próximas as potenciais, e possivelmente menores perdas de água excedente através da irrigação (Tabela 12), os quais poderiam afetar a produção do capim e nos aumentos dos custos pelo uso da irrigação, possivelmente aumentar a chance do $\mathrm{N}$ ser lixiviado ao lençol freático.

Tabela 12. Diferenças entre excedentes e deficiências hídricas $(\Delta \mathrm{BH}-\mathrm{mm})$ de cada coleta experimental, nos diferentes manejos de lâminas de irrigação em uma área de pastagem com capim-Tanzânia, em Piracicaba, SP.

\begin{tabular}{ccccccccccccc}
\hline Lâmina & \multicolumn{1}{c}{ Coleta } & & & & & Total \\
$(\mathrm{mm})$ & $1^{\mathrm{a}}$ & $2^{\mathrm{a}}$ & $3^{\mathrm{a}}$ & $4^{\mathrm{a}}$ & $5^{\mathrm{a}}$ & $6^{\mathrm{a}}$ & $7^{\mathrm{a}}$ & $8^{\mathrm{a}}$ & $9^{\mathrm{a}}$ & $1^{\mathrm{a}}$ & $(\mathrm{mm})$ \\
\hline $0 \% \mathrm{CC}^{1}$ & 220 & 249 & 7 & -7 & -32 & -32 & -25 & 23 & 44 & 10 & 457 \\
$30 \% \mathrm{CC}$ & 224 & 259 & 18 & 3 & -29 & -28 & -10 & 38 & 62 & 17 & 556 \\
$70 \% \mathrm{CC}$ & 229 & 274 & 33 & 14 & -23 & -19 & 10 & 59 & 85 & 24 & 689 \\
$100 \% \mathrm{CC}$ & 230 & 285 & 44 & 24 & -19 & -12 & 25 & 74 & 103 & 29 & 785 \\
$150 \% \mathrm{CC}$ & 237 & 303 & 61 & 47 & -17 & -2 & 51 & 100 & 132 & 38 & 953 \\
\hline
\end{tabular}

1. \%CC-porcentagem da capacidade de campo 
O modelo usado de balanço hídrico determinado para as diferentes lâminas de irrigação, sugerem que de maneira geral , os efeitos de clima e das lâminas de irrigação propiciariam efeito no crescimento e produção do capim-Tanzânia (Figuras de 9 a 23), o que não foi encontrado durante este experimento (Tabelas 9 e 10). Esse comportamento sugeririam efeito significativo relacionado ao tipo e textura de solo usado, uma vez que solos argilosos apresentariam maior capacidade de retenção de água.

\subsubsection{Movimento da água através do perfil do solo}

Visando observar a possível ocorrência de reposição hídrica pelas camadas mais profundas para as superficiais entre 0 a $20 \mathrm{~cm}$, nas quais o capim-Tanzânia apresenta maior concentração de sus raízes, determinou -se a variação de fluxo de água diário no solo $(q=\mathrm{mm} / \mathrm{dia})$, durante cada período de coleta experimental (Figuras 24,25 e 26).

As explicações teóricas dos processos físicos e desenvolvimentos matemáticos, envolvidos na determinação do fluxo de água no solo (Equação de Darcy), de condutividade hidráulica $(\mathrm{K}(\theta))$, sob condição de fluxo variável da água no solo (unsteady state), apresentam-se detalhadas em Reichardt (1985), Libardi (1995) e Marshall et al. (1999) . Considerando que um solo em condição natural de campo, está sujeito a variações de umidade $(\theta)$ ou potenciais matriciais $(\psi)$ no tempo, sabe-se que a sua condutividade hidráulica $(\mathrm{K})$ é função direta da sua variação de umidade $(\theta)$, e que decresce com o seu secamento (Reichardt, 1985); mas a condutividade é também dependente da geometria dos espaços porosos onde fatores como textura, estrutura, compactação e outros, podem afetar também nesta variação.

O solo estudado, que apresenta como característica textura argilosa ou muitoargilosa em profundidade, com variação de tamanho de poros de médios a pequenos (Anexo 1), tende a apresentar valores de condutividade hidráulica menores, e maior conteúdo de água no perfil para o mesmo potencial matricial, quando comparado a solo de textura mais arenosa (Marshall et al., 1999).

Nas Figuras de 24 a 26, observa-se que na profundidade entre 10 a $20 \mathrm{~cm}$ ocorreram as maiores variação de fluxo de água ascendente $(\mathrm{q}+)$ e descendente no solo 
(q-), sendo seguido geralmente pela profundidade $20-40 \mathrm{~cm}$, a qual participaram ascendendo água para a camada mais superficial em momentos de maior evapotranspiração .

As demais profundidades tenderam a não apresentar participação, quanto a possibilidade de ascensão de água para a superfície do solo e de estarem suprindo às raízes superficiais com a umidade profunda, que apresentaram potenciais matriciais sempre próximos a 0,20 bar abaixo de $60 \mathrm{~cm}$.

Possivelmente este solo de textura mais argilosa, apresentando maior capacidade de reter água em profundidade, poderiam estar suprindo as plantas durante o experimento com água, uma vez que $12 \%$ das raízes encontravam-se entre 40 a 100 $\mathrm{cm}$ de profundidade (Figura 1). A ocorrência desta hipótese, poderia ser confirmada com a diminuição em profundidade dos teores de fósforo e potássio durante $\mathrm{o}$ experimento (Tabelas de 6 a 8), o que mostraria tendência de atividade física e biológica destas raízes em profundidade, apresentando importante participação na absorção de água pela planta.

Somente com o secamento nas profundidades abaixo de $40 \mathrm{~cm}$ na quarta coleta, conseguiu-se a diminuição do teor de umidade em profundidade, e assim resposta para o efeito de uso de lâminas de irrigação em pastagem com capim-Tanzânia, considerando que os efeitos de demanda evaporativa eram significativos para o processo de evapotranspiração.

Efeitos significativos ao uso de lâminas de irrigação em pastagem seriam esperados em condições de solos com textura mais mediana, como também em condições de solos mais arenosos, típicos de áreas sob pastagem. 

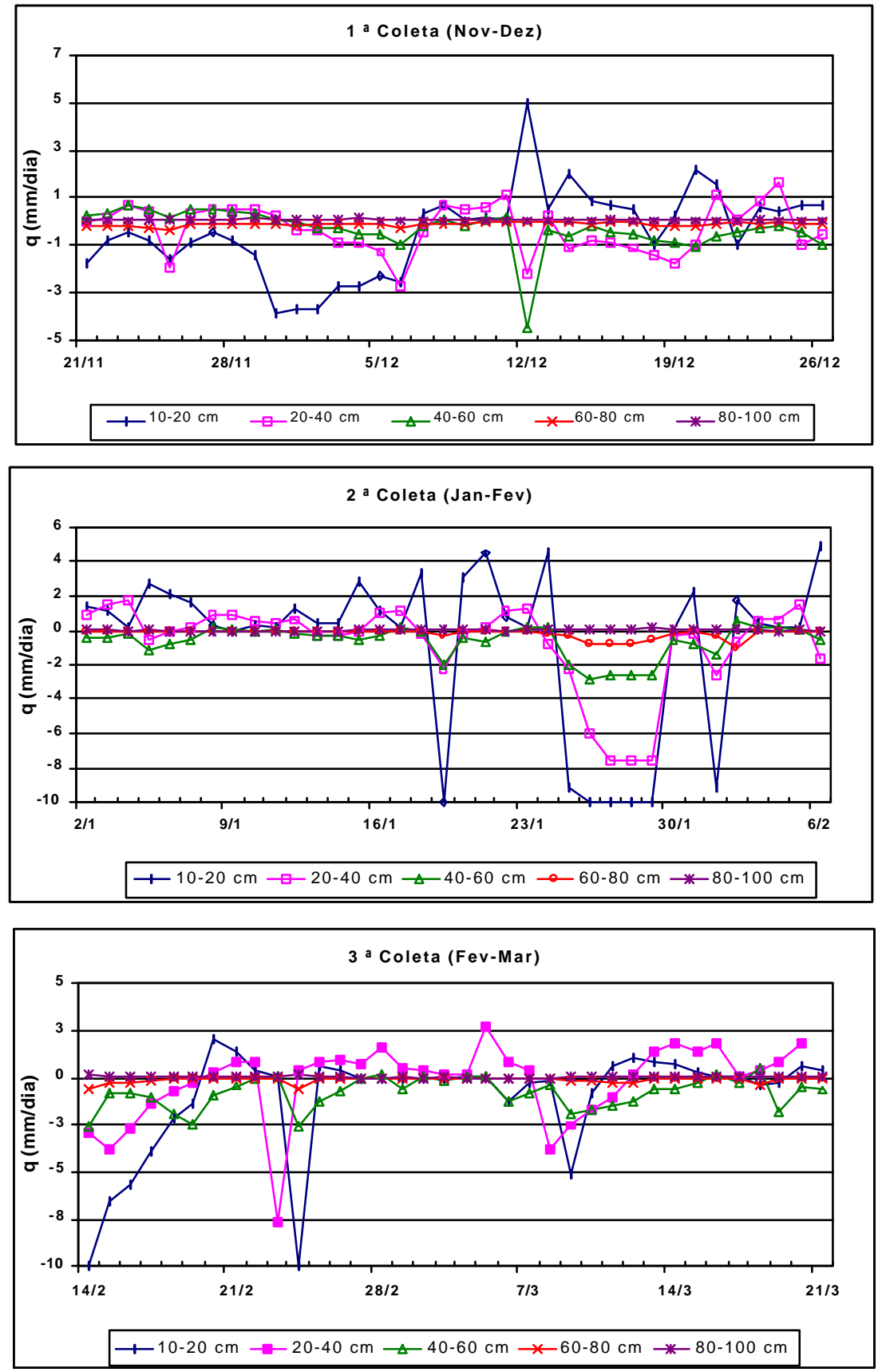

Figura 24 - Representação simplificada da variação de fluxo de água diária no solo $\left(q=m m \cdot d i a^{-1}\right)$ durante a estação do Verão $(21 / 11 / 2000$ a 21/03/2001), em uma área de pastagem com capim-Tanzânia, em Piracicaba, SP. 

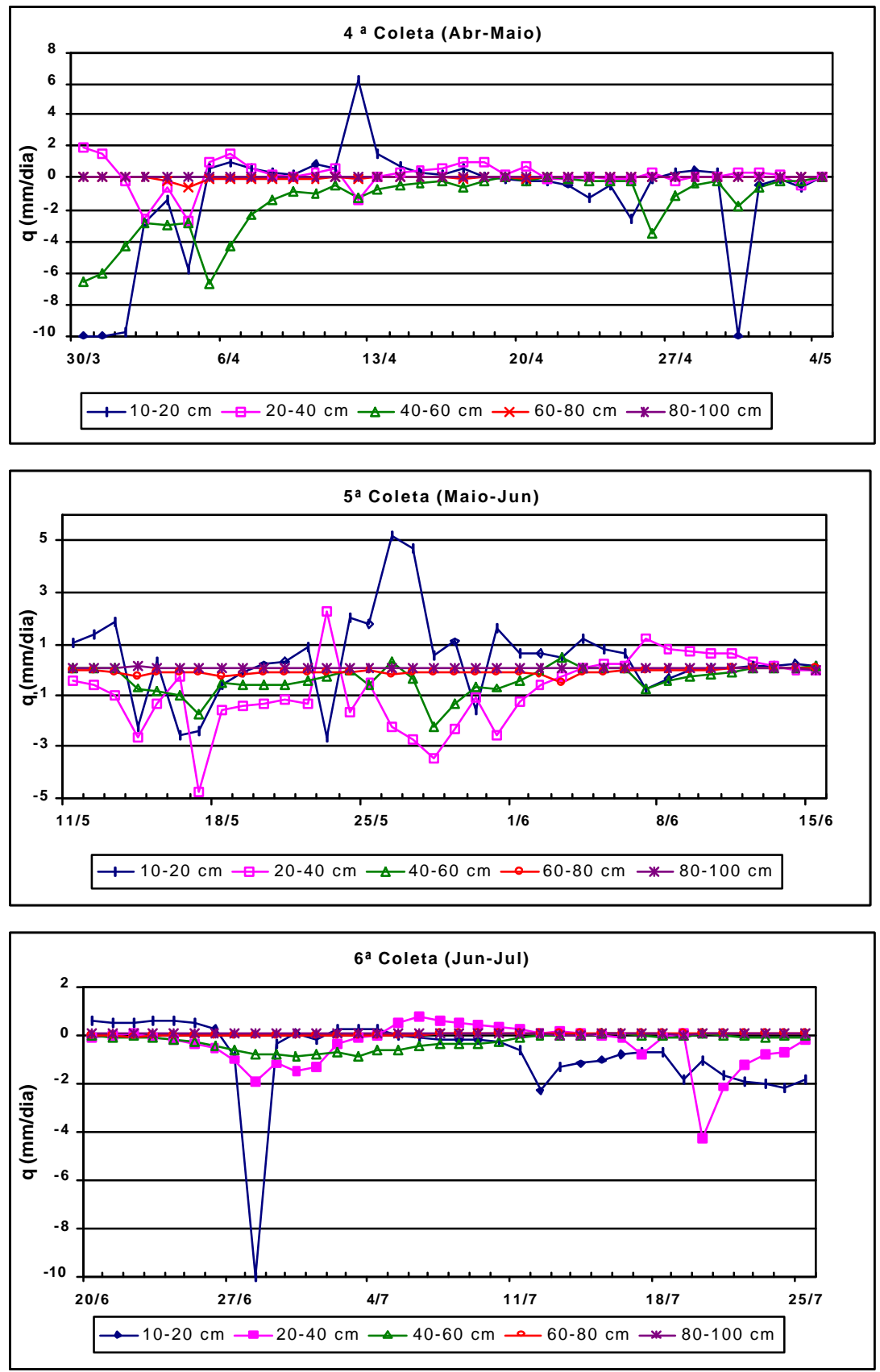

Figura 25 - Representação simplificada da variação de fluxo de água diária no solo $\left(q=m m \cdot d i a^{-1}\right)$ durante a estação de Inverno $(30 / 03$ a 25/07/2001), em uma área de pastagem com capim-Tanzânia, em Piracicaba, SP. 

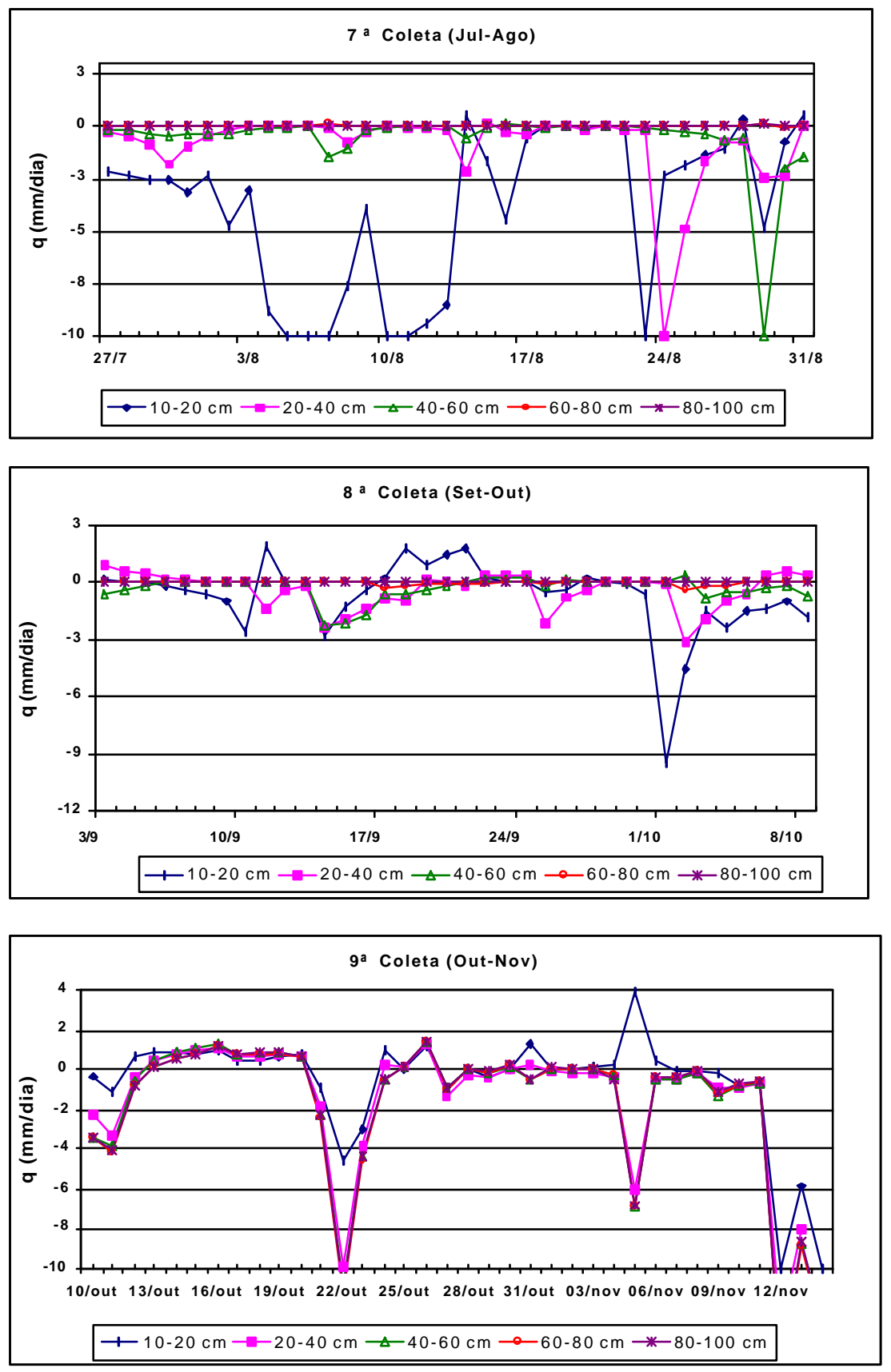

Figura 26 - Representação simplificada da variação de fluxo de água diária no solo $\left(\mathrm{q}=\mathrm{mm} \cdot \mathrm{dia}^{-1}\right)$ durante a estação da Primavera $(27 / 07$ a 14/11/2001), em uma área de pastagem com capim-Tanzânia, em Piracicaba, SP. 


\subsection{Avaliação do efeito do uso de adubação nitrogenada}

Os resultados das equações de regressão para variação de dose adubação nitrogenada dentro de cada lâmina de irrigação e coleta, e dentro de cada coleta em três estações climáticas, para a massa seca total em pastagem de capim-Tanzânia encontram-se nas Tabelas de 13 a 15. Já a variação em cada coleta de produção massa seca foliar e de hastes para diferentes doses de adubação nitrogenada, nas três estações climáticas encontram-se nas Tabelas de 17 e 18.

Observando as análises das variâncias presentes nas Tabelas de 1 a 4, tem-se que a interação tripla entre época de coleta, dose de adubação nitrogenada e lâminas de irrigação, usadas nas três estações climáticas estudadas foram significativas para a massa seca total, mas de maneira parcial para massa seca foliar (Tabela 1) e sem significância para massa seca de hastes (hastes, colmo e material senescido) (Tabelas 2 a 4).

Possivelmente a não significância tripla para massa seca foliar e para haste (Anexos 2 e 3 ), deve-se a maior variância dos valores de hastes encontrados nas doses menores de nitrogênio, em cada bloco. Valores encontrados para haste, poderiam apresentar-se como zero ou não, quando considerado os seus valores nas sub-parcelas dos diferentes blocos quando da determinação a porcentagem de folha no material colhido.

O número de blocos e de sub-amostras coletadas para determinação da produção de massa seca de haste e folhas poderia ser maior, mas devido ao tamanho experimental (75 sub-parcelas) e da quantidade de amostras coletadas para secagem (total de 225 amostras com aproximadamente $1 \mathrm{~kg}$ de material verde), mostraram-se como limitantes para o aumento na amostragem experimental.

Fatores de ordem física (espaço para trabalho), instrumental (estufas de secagem), pessoal e tempo de coleta, mostraram-se como limitantes para a diminuição da variação destes dados estudados. Portanto, para a discussão dos dados de produção de massa seca foliar e de haste foi considerada a interação dupla de tempo de coleta e dose de nitrogênio usada (Tabelas 17 e 18), onde com o aumento da quantidade amostral obteve-se diminuição na variância dos valores de produção encontrados, e assim 
possibilitando encontrar (Tabelas 1 a 3) efeito significativo dentro desta interação, nas três estações climáticas estudadas. Esta variação foi maior durante as estações de inverno e primavera, onde pequenas variações de produção de massa seca nas subparcelas, ocasionaram efeitos importantes nos resultados das análises estatísticas efetuadas.

\subsubsection{Produção de massa seca total}

Em estudos de crescimento e produção de gramíneas forrageiras tropicais, como o capim Tanzânia, uma leitura atenciosa do capitulo "material e métodos" nos diferentes trabalhos científicos publicados, torna-se importante quando se busca fazer comparação de resultados de pesquisa. Uma vez que diferenças em denominações da massa seca colhida, diferenças de idades de corte das pastagens e quantidades de adubação nitrogenada usadas são comumente encontrados.

Em comparações de resultados de produção de massa seca total, às vezes produções massa seca mostram-se diferentes, mesmo comparadas dentro de condição climática semelhante. Variações nos métodos dos trabalhos revisados em relação a diferença de altura de corte, dose e parcelamento de nitrogênio, permitem que diferenças de participação de partes da planta (folha e hastes) ocorram, e assim acabarem por influírem de maneira significativa na produção total de massa seca obtida.

Tozi (1999) e Rosseto (2000) trabalhando com capim-Tanzânia, com diferentes doses de nitrogênio ( $80 \mathrm{~kg} \mathrm{~N}$ e $50 \mathrm{~kg} \mathrm{~N}$ após cada pastejo) e altura de corte ( $35 \mathrm{~cm}$ e 20 $\mathrm{cm}$ ), apresentam diferenças de produção de massa seca significativas para mesma

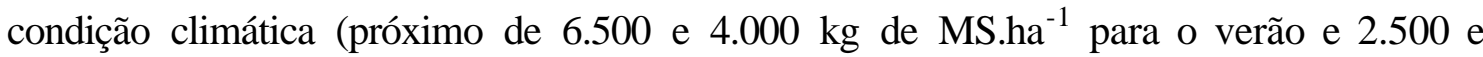
$1.280 \mathrm{~kg} \mathrm{MS} . \mathrm{ha}^{-1}$ no inverno), o que então justifica maior atenção na interpretação de resultados de produção.

A produção de massa seca total neste trabalho, considera como Tozi (1999), a quantificação de todo material (folha, haste, colmos e material senescente) presente acima da altura de $20 \mathrm{~cm}$, e apresenta como melhor terminologia e entendimento àquela usada por Ramos (1997): produção de massa seca da parte aérea. 
A análise da variância para interação tripla com relação ao efeito do uso de doses de nitrogênio, para cada lâminas de irrigação e coleta, considerada dentro das três estações estudadas, mostrou-se significativa para a produção de massa seca total (Tabelas 13 a 15), sendo que o comportamento quanto às equações de regressão encontradas mostraram-se com maior tendência de efeito linear para produção de massa seca total com a aplicação de nitrogênio (Tabelas 13 a 15), quando consideradas as diferentes lâminas de irrigação usadas.

Vicente-Chandler et al. (1962) visando observar a resposta de Panicum maximum ao uso de diferentes doses de nitrogênio (0, 224, 448, 720 e 896 kgN.ha ${ }^{-1}$.ano $\left.{ }^{-1}\right)$ em diferentes frequiências de aplicação colhida a cada 45 dias, mostraram que o uso de nitrogênio proporcionou aumento na produção anual de massa seca produzida na ordem

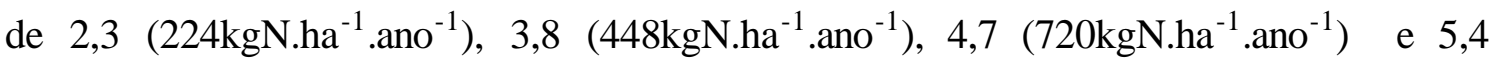
$\left(896 \mathrm{kgN} \cdot \mathrm{ha}^{-1} \cdot \mathrm{ano}^{-1}\right)$ vezes, quando comparados a testemunha. Os valores de coleta médio da produção de massa seca total, obtidos durante as estações de verão, primavera

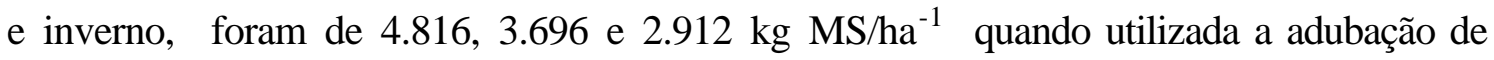
$720 \mathrm{~kg} \mathrm{~N} \cdot \mathrm{ha}^{-1} \cdot \mathrm{ano}^{-1}$. Assim, as gramíneas tendem a mostrar respostas mais significativas à fertilização com nitrogênio, durante as estações de maior rapidez crescimento (quentes e úmidas), do que durante os meses de inverno que são frios e secos (Vicente-Chandler, 1973).

Valores de produção de massa seca total e relações semelhantes foram também encontrados por Vasquez (1965), quando trabalhando com doses de nitrogênio de 0, 448, e $896 \mathrm{kgN} \cdot \mathrm{ha}^{-1} \cdot \mathrm{ano}^{-1}$ em cinco gramíneas, verificou que o nitrogênio produziu aumento na produção para as parcelas que receberam $448 \mathrm{kgN} \mathrm{ha}^{-1} \cdot \mathrm{ano}^{-1}$ maior quando comparada aquela não adubada, do que a proporção de aumento obtido quando comparada esta dosagem a de $896 \mathrm{kgN} \cdot \mathrm{ha}^{-1} \cdot$ ano $^{-1}$. Um efeito positivo do uso de irrigação e nitrogênio também foi encontrado

$\mathrm{Na}$ estação do verão, a produção média de massa seca total das parcelas que não receberam adubo nitrogenado (média das produções iniciais determinadas pelas equações de regressão do Tabela 13), foram maiores durante a primeira coleta experimental ( 3.250,0 kg MS.ha $\left.{ }^{-1}\right)$, quando comparando às demais coletas $(1.494,0 \mathrm{e}$ 1.293,0 kg MS.ha ${ }^{-1}$ ) 
Esta maior produção inicial em todas lâminas de irrigação dentro da primeira coleta, pode ter ocorrido por dois fatores: a- aumento da precipitação natural e da temperatura média diária; b- maior mineralização da matéria orgânica recém depositada após o pastoreio, e também daquela matéria orgânica incorporada após a implantação da pastagem na área experimental (Tabela 5).

Tabela 13. Equações de regressão para variação de dose de adubação nitrogenada dentro de cada lâmina de irrigação e coleta, na estação do Verão para a massa seca total em pastagem de capim-Tanzânia estabelecido numa Terra Roxa Estruturada, avaliados em área experimental da Fazenda Areão, Piracicaba, SP.

\begin{tabular}{|c|c|c|c|c|c|}
\hline Lâmina $^{(1)}$ & Coleta & Equação & $\mathrm{R}^{2}$ & $\operatorname{MPMS}^{(3)}$ & $\begin{array}{c}\text { Dose N para } \\
\text { máxima } \\
\text { MPMS }^{(2)}\end{array}$ \\
\hline 0 & & $\mathrm{NS}$ & - & - & - \\
\hline 30 & & $3.273,44+1,09 X$ & $0,45^{*}$ & $5.539,6$ & $2.079,0$ \\
\hline 70 & 1 & $3.689,75+0,62 X$ & $0,36^{@}$ & $4.978,7$ & $2.079,0$ \\
\hline 100 & & $2.789,79+0,94 X$ & $0,87^{*}$ & $4.744,1$ & $2.079,0$ \\
\hline 150 & & NS & - & - & - \\
\hline 0 & & $1.579,19+2,32 X$ & $0,93^{* *}$ & $6.402,4$ & $2.079,0$ \\
\hline 30 & & $2.065,42+0,92 X$ & $0,31^{*}$ & $3.978,1$ & $2.079,0$ \\
\hline 70 & 2 & $1.542,44+2,07 X$ & $0,95^{* *}$ & $5.845,9$ & $2.079,0$ \\
\hline 100 & & $819,8+4,69 X-0,0013 X^{2}$ & $0,94^{@}$ & $5.049,8$ & $1.803,8$ \\
\hline 150 & & $1.468,39+1,63 X$ & $0,92^{* *}$ & $4.863,4$ & $2.079,0$ \\
\hline 0 & & NS & - & - & - \\
\hline 30 & & NS & - & - & - \\
\hline 70 & 3 & $1.312,58+0,81 \mathrm{X}$ & $0,76^{*}$ & $2.996,6$ & $2.079,0$ \\
\hline 100 & & $1.547,23+0,65 X$ & $0,52^{@}$ & $2.898,6$ & $2.079,0$ \\
\hline 150 & & $1.022,79+1,08 X$ & $0,83^{* *}$ & $3.268,1$ & $2.079,0$ \\
\hline
\end{tabular}

1- Porcentagem da capacidade de campo ; 2- kg N.ha ${ }^{-1}$. ano $^{-1}$

3- MPMS - Máxima produção de massa seca total (kg MS.ha ${ }^{-1} .36$ dias $^{-1}$ )

@ $\mathrm{p}<0,10 ; * \mathrm{p}<0,05 ; * * \mathrm{p}<0,01 ; * * * \mathrm{p}<0,001 ; \mathrm{NS}-\mathrm{Não}$ significativo 
Raij (1991) mostrou que a variação do N-nítrico, em terra roxa da região de Campinas, em um estudo de 2 anos, tende a apresentar aumento no acúmulo de nitrato nos períodos mais chuvosos e redução nos períodos mais secos, em função de estímulo para aumento na taxa de mineralização da matéria orgânica presente no solo.

Possivelmente, o grande número de animais usados para o pastejo inicial (25 animais.1200 $\mathrm{m}^{-1}$ ), tenham deixado um excesso de excreções sobre o solo, de maneira que a mineralização das formas orgânicas hidro-solúveis e do material sólido coloidal possam ter sido rápida, e ter aumentado a concentração de nitrogênio mineral em curto espaço de tempo (Jarvis et al., 1995). Geralmente a maior parte do nitrogênio incorporado na biomassa microbiana é facilmente biodegradável, liberando nitrogênio inorgânico à taxas dependente somente da razão $\mathrm{C}: \mathrm{N}$, que deve ser menor no esterco recém defecado.

Stout (1992), trabalhando com Panicum virgatum L. cv. Cave-n-Rock em dois solos com características distintas de armazenamento de água e altitudes, encontrou no período de verão em solos que apresentavam maiores níveis de nitrogênio orgânico, redução na resposta ao uso de nitrogênio, onde o aumento na produção de massa seca foi obtido com pouco ou nenhum nitrogênio utilizado, devido a mineralização da matéria orgânica presente no solo. Este fato foi atribuído também a altitude do solo usado, o qual recebeu uma quantidade de radiação 14\% maior comparada ao de maior altitude .

Esta atividade na matéria orgânica foi contínua durante todo período experimental, como pode ser observado nas Tabelas de 13 a 15, com a variação do clima durante o ano agrícola observou-se diferentes efeitos nas produção inicial de massa seca total .

Com o uso da dose máxima estimada para a MPMS pelas equações de regressões, inicialmente encontrou-se efeito positivo ao uso do nitrogênio e maior produção de massa seca total nos dois primeiros períodos de coletas, onde produções médias em cada período foram de como $5.084 \mathrm{~kg} \mathrm{MS.ha-1} \mathrm{e} 5.227 \mathrm{~kg} \mathrm{MS.ha}{ }^{-1}$, superiores em aproximadamente $40 \%$ aos valores médios de produção encontrados na

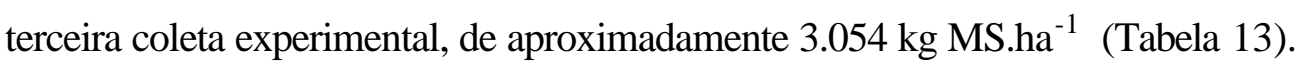

Com pequena diminuição da temperatura média, da evapotranspiração e radiação global (Figuras 2 e 3) a partir de março de 2001, ocorreu queda de 
aproximadamente $40 \%$ na produção total de massa seca total em comparação aos demais períodos nesta estação.

Tabela 14. Equações de regressão para variação de dose de adubação nitrogenada dentro de cada lâmina de irrigação e coleta, na estação do Inverno para a massa seca total em pastagem de capim-Tanzânia estabelecido numa Terra Roxa Estruturada, avaliados na Fazenda Areão, Piracicaba, SP.

\begin{tabular}{|c|c|c|c|c|c|}
\hline .Lâmina ${ }^{(1)}$ & Coleta & Equação & $\mathrm{R}^{2}$ & $\operatorname{MPMS}^{(3)}$ & $\begin{array}{c}\text { Dose N para } \\
\text { máxima } \\
\text { MPMS }^{(2)}\end{array}$ \\
\hline 0 & & $774,19+3,27 \mathrm{X}-0,0011 \mathrm{X}^{2}$ & $0,98 *$ & $3.204,4$ & $1.486,4$ \\
\hline 30 & & $1.404,74+2,06 X-0,00079 X^{2}$ & $0,56^{*}$ & $2.747,7$ & $1.303,8$ \\
\hline 70 & 4 & $1.454,09+1,88 X-0,00049 X^{2}$ & $0,86^{*}$ & $3.257,4$ & $1.918,4$ \\
\hline 100 & & $1.547,95+0,75 X$ & $0,84^{* * *}$ & $3.107,2$ & $2.079,0$ \\
\hline 150 & & $1.060,52+0,69 X$ & $0,63^{* * *}$ & $2.349,5$ & $2.079,0$ \\
\hline 0 & & NS & - & - & - \\
\hline 30 & & $361,96+1,17 X-0,00047 X^{2}$ & $0,88^{*}$ & $1.090,1$ & $1.244,7$ \\
\hline 70 & 5 & NS & - & - & - \\
\hline 100 & & $394,93+0,24 X$ & $0,89^{*}$ & 893,9 & $2.079,0$ \\
\hline 150 & & $373,63+0,34 X$ & $0,97^{* *}$ & 706,9 & $2.079,0$ \\
\hline 0 & & NS & - & - & - \\
\hline 30 & & NS & - & - & - \\
\hline 70 & 6 & $392,96+0,26 X$ & $0,73^{*}$ & 933,5 & $2.079,0$ \\
\hline 100 & & $329,46+0,28 X$ & $0,82^{*}$ & 911,6 & $2.079,0$ \\
\hline 150 & & $326,44+0,28 X$ & $0,76^{*}$ & 908,6 & $2.079,0$ \\
\hline
\end{tabular}

1- Porcentagem da capacidade de campo ; 2 - $\mathrm{kg} \mathrm{N}^{-h^{-1}}$.ano $^{-1}$

3 - MPMS - Máxima produção de massa seca total (kg MS.ha ${ }^{-1} .36$ dias $^{-1}$ )

$\star \mathrm{p}<0,05 ; * \star \mathrm{p}<0,01 ; \star \star \star \mathrm{p}<0,001$

No período denominado inverno, a produção média de massa seca total das parcelas que não receberam adubo nitrogenado (médias das produções iniciais determinadas pelas equações de regressão do Tabela 14), apresenta de maneira clara os efeito das mudanças provocadas pelo clima (diminuição de temperatura e fotoperíodo), 
quando a partir da quarta coleta $\left(1.247,8 \mathrm{~kg}\right.$ MS.ha $\left.{ }^{-1}\right)$, teve-se redução no desenvolvimento do capim-Tanzânia, resultando em apenas um período de coleta e redução de aproximadamente $69 \%$ na produção de massa seca nas duas coletas subsequentes (376,0 kg MS.ha- ${ }^{-1}$ e 349,0 kg MS.ha- ${ }^{-1}$ ).

A produção de massa seca total, quando consideranda as doses máximas de nitrogênio estimadas, apresentou a mesma proporção de redução de produção de massa seca total (69\%), em função das condições climáticas verificadas no período. Para a

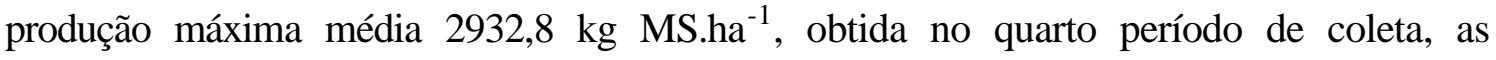
produções reduziram-se para valores entre 896,7 kg MS.ha ${ }^{-1}$ e 917,3 kg MS.ha-1 em média nas duas coletas seguintes (Tabela 14).

Com o início do período primavera (a partir de agosto de 2001), teve-se um aumento de aproximadamente $30 \%$ em média nas produções de massa seca total, quando não usou-se adubação nitrogenada. Um aumento de mais de $57 \%$ nas produções de massa seca totais médias (1.284 kg MS.ha ${ }^{-1}$ ) (Tabela 15) obteve-se com a elevação das temperaturas médias diárias a partir da nona coleta, quando compara-se as produções

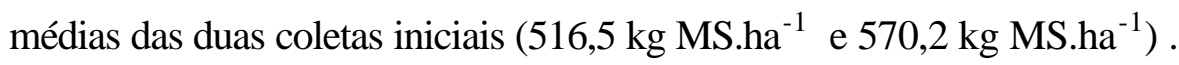

Algo que deve ser observado quando se faz uso da dose máxima de nitrogênio prevista pelas equações de regressão, é que o efeito do uso do nitrogênio nas dosagens recomendadas apresentou aumento médio crescente na produção de massa seca total (efeito linear), que acompanhou o aumento da temperatura diária e da evapotranspiração (Figuras 1 e 2 Quadro 10). A partir da sexta coleta, os aumentos mensais de produção até a nona coleta foram de 44\% (coletas 67), 34\% (coletas 7-8) e 39\% (coletas 8-9) respectivamente, e com aumento de mais de quatro vezes na produção de massa seca total, quando considerado a produção final do inverno e da primavera (coletas 6 e 9). As produções de massa seca total, foram em média por coleta de $1.630 \mathrm{~kg}$ MS.ha $^{-1}, 2.474$ kg MS.ha ${ }^{-1}$ e 4.024 kg MS.ha ${ }^{-1}$, respectivamente (Tabela 15). 
Tabela 15. Equações de regressão para variação de dose de adubação nitrogenada dentro de cada lâmina de irrigação e coleta, na estação da Primavera para a massa seca total em pastagem de capim-Tanzânia estabelecido numa Terra Roxa Estruturada, avaliados em área na Fazenda Areão, Piracicaba, SP.

\begin{tabular}{|c|c|c|c|c|c|}
\hline .Lâmina ${ }^{(1)}$ & Coleta & Equação & $\mathrm{R}^{2}$ & $\operatorname{MPMS}^{(3)}$ & $\begin{array}{c}\text { Dose N para } \\
\text { máxima } \\
\text { MPMS }^{(2)}\end{array}$ \\
\hline 0 & & $473,97+0,34 X$ & $0,55^{*}$ & $1.180,8$ & $2.079,0$ \\
\hline 30 & & $502,32+0,46 X$ & $0,77^{*}$ & $1.458,7$ & $2.079,0$ \\
\hline 70 & 7 & $558,64+0,68 X$ & $0,85^{* *}$ & $1.972,4$ & $2.079,0$ \\
\hline 100 & & $452,42+0,61 X$ & $0,86^{* *}$ & $1.720,6$ & $2.079,0$ \\
\hline 150 & & $597,30+0,59 X$ & $0,68^{* *}$ & $1.823,9$ & $2.079,0$ \\
\hline 0 & & $497,58+0,57 X$ & $0,60^{* *}$ & $1.682,6$ & $2.079,0$ \\
\hline 30 & & $557,09+0,82 X$ & $0,74^{* *}$ & $2.261,9$ & $2.079,0$ \\
\hline 70 & 8 & $671,28+1,01 X$ & $0,79^{* * *}$ & $2.771,1$ & $2.079,0$ \\
\hline 100 & & $599,77+0,99 X$ & $0,76^{* * *}$ & $2.657,9$ & $2.079,0$ \\
\hline 150 & & $526,65+1,19 X$ & $0,82^{* * *}$ & $3.000,7$ & $2.079,0$ \\
\hline 0 & & $1.514,16+1.15 \mathrm{X}$ & $0,49^{* * *}$ & $3.905,0$ & $2.079,0$ \\
\hline 30 & & $1.207,03+1,18 X$ & $0,79^{* * *}$ & $3.660,3$ & $2.079,0$ \\
\hline 70 & 9 & $1.245,48+1,24 X$ & $0,87^{* * *}$ & $3.823,4$ & $2.079,0$ \\
\hline 100 & & $1.334,86+1,47 X$ & $0,82^{* *}$ & $4.390,9$ & $2.079,0$ \\
\hline 150 & & $1.132,87+1,54 X$ & $0,93^{* *}$ & $4.345,5$ & $2.079,0$ \\
\hline
\end{tabular}

1- Porcentagem da capacidade de campo ; 2 - kg N/ha .ano

3 - MPMS - Máxima produção de massa seca total (kg MS/ha.36 dias)

$\star \mathrm{p}<0,05 ; * \star \mathrm{p}<0,01 ; * \star \star \mathrm{p}<0,001$

O uso de nitrogênio permitiu aumento de produção de massa seca total, dentro das três estações climáticas estudadas, com variações de produção durante o ano agrícola que seguiram as modificações climáticas (Tabelas 13 a 15), o que mostrou evidente efeito da ocorrência da estacionalidade de produção de fitomassa devido a presença de fatores climáticos limitantes ao crescimento do capim, como temperatura e luz, na região de Piracicaba -SP.

Pinheiro (2002) usou um método para estimativa da produtividade do capimTanzânia (Panicum maximun cv. Tanzânia) através de um modelo matemático (função de Gompertz), calibrado em função da somatório de unidades fototérmicas e níveis de 
adubação nitrogenada $0,100,275,756$ e $2.079 \mathrm{~kg} \mathrm{de} \mathrm{N} \mathrm{ha}^{-1} \mathrm{ano}^{-1}$, conduzido de janeiro a dezembro de 2001, no município de Piracicaba - SP. A produção de massa seca do capim-Tanzânia, avaliada na época de corte no período de 02/01/2001 a 21/12/2001, apresentou estacionalidade de produção devido aos fatores de crescimento (radiação solar e temperatura), chegando à máxima produção de 4.570,8 $\mathrm{kg} \mathrm{MS} \mathrm{ha}^{-1}$, no mês de fevereiro, após o período de 36 dias de descanso, com adubação $2079 \mathrm{~kg} \mathrm{~N} \mathrm{ha}^{-1}$ ano $^{-1}$ e a mínima produção de 292,30 kg MS ha ${ }^{-1}$, no mês de julho, após o período de 36 dias de descanso.

As sub-parcelas testemunhas que receberam doses zero de nitrogênio, mostraram-se no final do período experimental degradação significativa da parte aérea, o que resultaria a médio prazo em possível eliminação total do capim-Tanzânia por plantas invasoras nessas parcelas experimentais.

Kichel et al. (1997) comentaram que o processo de degradação se caracteriza como a perda evolutiva de vigor, produtividade, capacidade de recuperação natural das pastagens para sustentar os níveis de produção e qualidade exigida pelos animais, assim como, a de superar os efeitos nocivos de pragas, doenças e invasoras, culminando com a degradação avançada dos recursos naturais. Ocorre, então, redução na produção de forragem e também do seu valor nutritivo, onde mesmo em épocas favoráveis ao crescimento, tem-se queda considerável na produtividade potencial para as condições edafo-climáticas e bióticas a que está submetida, e por final a produção de forragem acaba por perder gradativamente a capacidade de manter determinado número de animais no pasto por determinado período de tempo.

Nascimento Jr. et al.(1994), citaram algumas formas de avaliação do grau de degradação das pastagens, no qual o método que pareceu ser bastante prático é o que avalia a condição da pastagem dividindo-a em quatro classes de degradação que dependiam da condição de pastagem presente na área trabalhada (pastagem excelente, boa, razoável e pobre). No final do trabalho experimental, as pastagens degradadas se mostravam classificadas como condição de pastagem pobre, apresentando menos de $25 \%$ da sua produção potencial no período final experimental.

$\mathrm{O}$ efeito do uso do nitrogênio durante todo o período experimental, proporcionou nas doses máximas de nitrogênio estimadas pelas equações, aumentos de mais de $50 \%$ 
nas produções de massa seca total em capim Tanzânia, onde variações mensais a partir da segunda coleta foram de 71\%, 58\%, 58\%, 58\%, 62\%, 68\%, 77\% e 68\%, respectivamente, quando comparadas às sub-parcelas não adubadas. Exceção foi encontrada na primeira coleta, onde devido aos fatores já discutidos anteriormente, apresentaram diferença de somente $36 \%$ entre a mínima e a máxima dose de nitrogênio.

A variação de produção de massa seca por coleta, dentro de todas as estações climáticas estudadas, seguiu a mesma distribuição temporal encontrada por Tosi (1999), onde os valores de produção de massa seca total, mostraram sempre superiores aos valores encontrados neste trabalho, possivelmente a idade da pastagem tenha influenciado nesta maior produção, uma vez que a pastagem nesse experimento ainda estava em formação (segundo ano de estabelecimento).

A taxa de acúmulo diário de massa seca para cada estação de estudo, estimada com base nos valores médios de produções de massa seca total determinada para variação de dose adubação nitrogenada, considerando o efeito de cada lâmina de irrigação e período coleta, dividido pelos intervalos entre pastejo usado (36 dias), são mostrados com tendência de comportamento nas Figuras de 27 a 29.

A taxa de acúmulo apresentou como tendência, diminuição a cada ciclo de pastejo (Figuras 27 a 29) até os períodos de coleta 5 e 6, o que caracterizou bem a presença de estacionalidade de produção do capim-Tanzânia na estação de inverno.

As taxas médias de acúmulo obtidas durante o verão, apresentaram para as variações das doses de nitrogênio usadas (de 0 a $2079 \mathrm{KgN} \mathrm{ha}^{-1} \mathrm{ano}^{-1}$ ), valores oscilando entre 35,7 kg MS ha ${ }^{-1} \cdot \mathrm{dia}^{-1}$, 35,6 kg MS.ha ${ }^{-1} \cdot \mathrm{dia}^{-1}$, 55,6 kg MS.ha- ${ }^{-1} \cdot \mathrm{dia}^{-1}$, 82,4 kg MS.ha ${ }^{-}$ ${ }^{1} \cdot \mathrm{dia}^{-1}$ e $133,9 \mathrm{~kg} \mathrm{MS} \cdot \mathrm{ha}^{-1} \cdot \mathrm{dia}^{-1}$, respectivamente, no segundo período de coleta (Janeiro/2001), tendendo ao decréscimo até o período de coleta 6 (Julho/2001), atingindo os acúmulos mínimos médios de 9,2 kg MS.ha ${ }^{-1} \cdot \mathrm{dia}^{-1}, 9,5 \mathrm{~kg} \mathrm{MS} \cdot \mathrm{ha}^{-1} \cdot \mathrm{dia}^{-1}$, 14,0 kg MS.ha ${ }^{-1} \cdot \mathrm{dia}^{-1}$, 20,5 kg MS.ha ${ }^{-1} \cdot \mathrm{dia}^{-1}$ e 23,0 kg MS.ha ${ }^{-1} \cdot \mathrm{dia}^{-1}$ para as diferentes doses de nitrogênio usadas. 

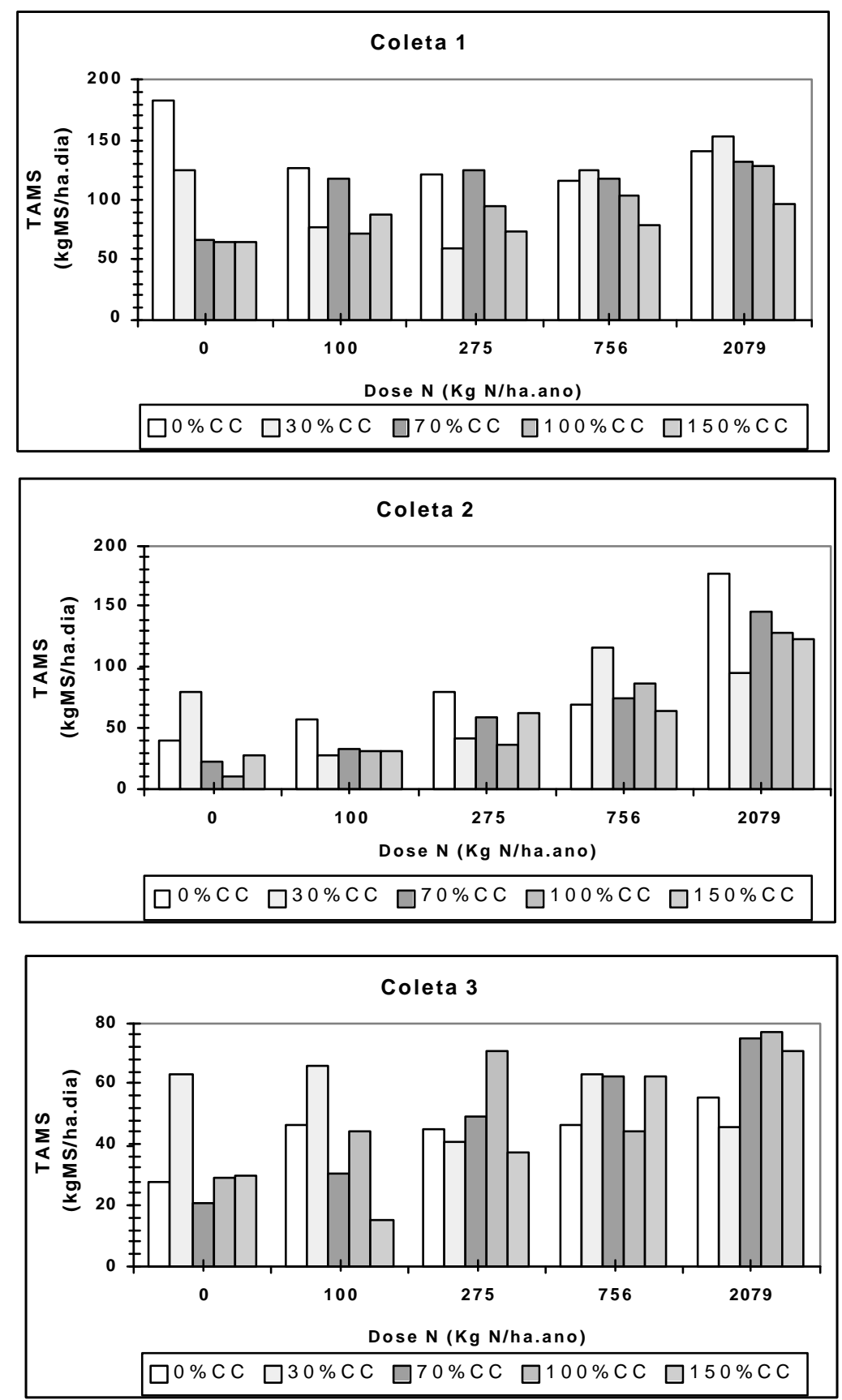

Figura 27 - Variação da taxa de acúmulo da massa seca total média $\left(\mathrm{kg} \mathrm{MS} \mathrm{ha}^{-1} \cdot \mathrm{dia}^{-1}\right)$ do capim-Tanzânia, em função de doses crescentes de adubo nitrogenado, em diferentes lâminas de irrigação usadas e coletas experimentais durante a estação do Verão, avaliados em área na Fazenda Areão, Piracicaba, SP. 

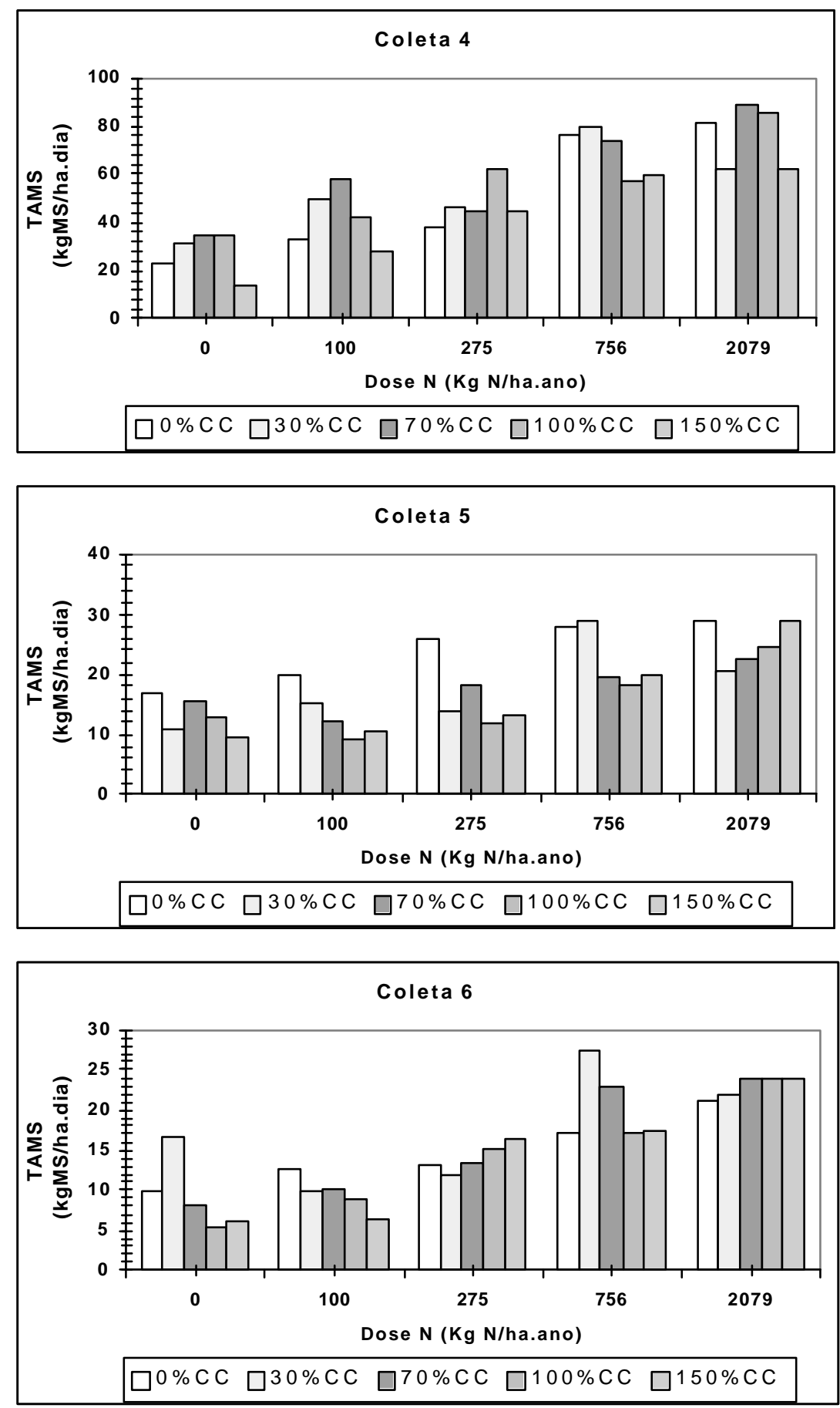

Figura 28 - Variação da taxa de acúmulo da massa seca total média (kg MS.ha ${ }^{-1}$.dia $\left.{ }^{-1}\right)$ do capim-Tanzânia, em função de doses crescentes de adubo nitrogenado, em diferentes lâminas de irrigação usadas e coletas experimentais durante a estação do Inverno, avaliados em área na Fazenda Areão, Piracicaba, SP. 

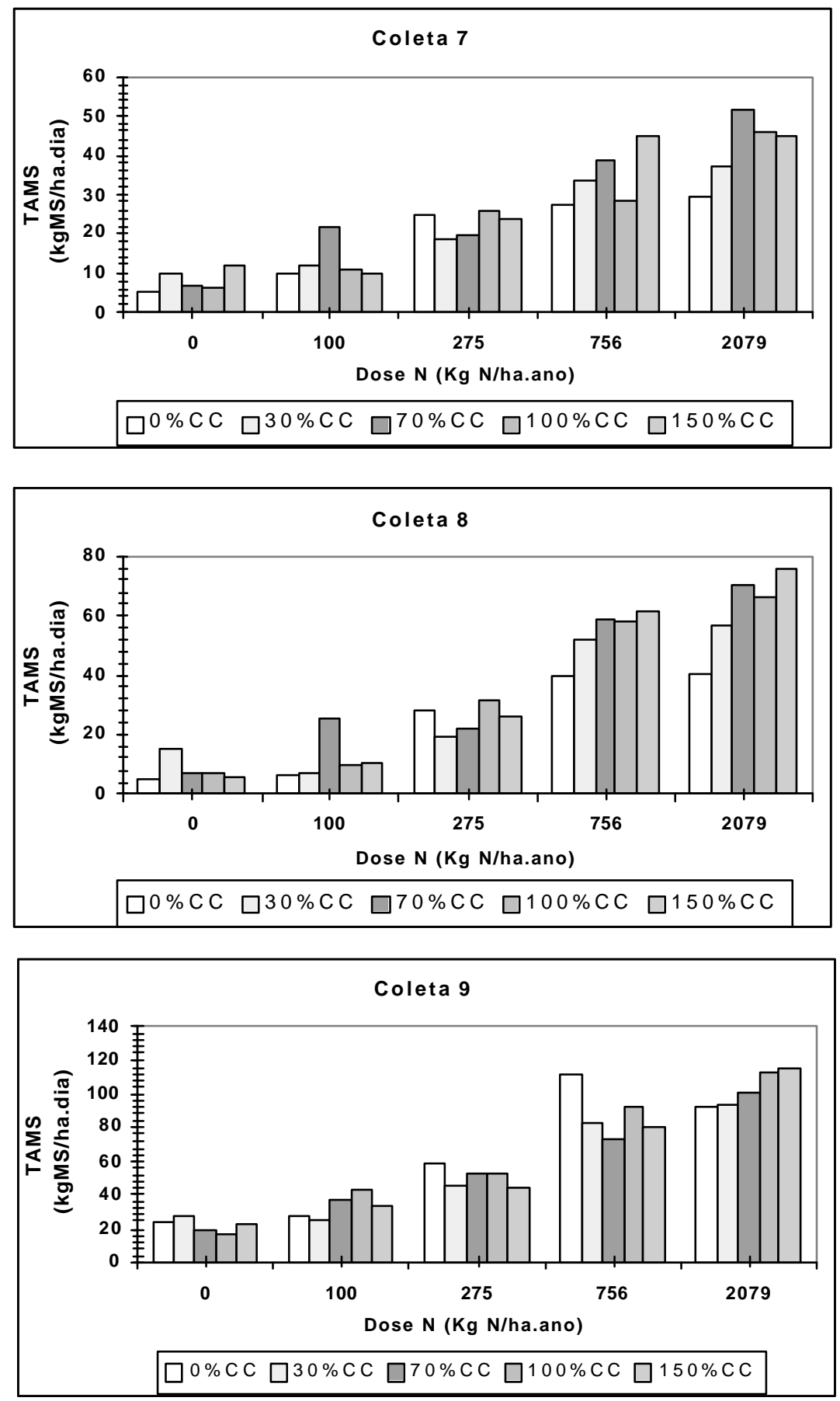

Figura 29 - Variação da taxa de acúmulo da massa seca total média (kg MS.ha ${ }^{-1} \cdot$ dia $\left.^{-1}\right)$ do capim-Tanzânia, em função de doses crescentes de adubo nitrogenado, em diferentes lâminas de irrigação usadas e coletas experimentais durante a estação da Primavera, avaliados em área na Fazenda Areão, Piracicaba, SP. 
A partir do período de coleta 7 , obteve-se novamente a elevação dos valores de taxa média de acúmulo, chegando no final da primavera a valores de 21,9 kg MS.ha ${ }^{-}$ ${ }^{1} \cdot \mathrm{dia}^{-1}$, 33,3 kg MS.ha ${ }^{-1} \cdot \mathrm{dia}^{-1}$, 50,6 kg MS.ha ${ }^{-1} \cdot \mathrm{dia}^{-1}, 87,8 \mathrm{~kg} \mathrm{MS} \cdot \mathrm{ha}^{-1} \cdot \mathrm{dia}^{-1}$ e 102,6 kg MS.ha ${ }^{-1} \cdot \mathrm{dia}^{-1}$, quando consideradas as diferentes doses de nitrogênio.

Comparando este trabalho ao resultado de três experimentos conduzidos por Tozi (1999), Rosseto (2000) e Lugão (2001), usando dose comum média de aplicação nitrogênio de $300 \mathrm{~kg} \mathrm{~N} \cdot \mathrm{ha}^{-1} \cdot \mathrm{ano}^{-1}$ (mas com parcelamentos diferentes) e em períodos climáticos semelhantes de coletas (1 a 5), observou-se que os valores de taxa de acúmulo de massa seca total encontrados mostraram-se sempre menores $\left(1^{\mathrm{a}}-88 \mathrm{~kg} \mathrm{MS} \cdot \mathrm{ha}^{-1} \cdot \mathrm{dia}^{-1}\right.$; $2^{\mathrm{a}}$ - $61 \mathrm{~kg} \mathrm{MS} \cdot \mathrm{ha}^{-1} \cdot \mathrm{dia}^{-1} ; 3^{\mathrm{a}} 45 \mathrm{~kg} \mathrm{MS} \cdot \mathrm{ha}^{-1} \cdot \mathrm{dia}^{-1}$ ) quando comparados àqueles períodos de maior favorecimento ao crescimento da gramínea, e assemelhando-se na quarta coleta $\left(4^{\mathrm{a}}-51 \mathrm{~kg} \mathrm{MS} \cdot \mathrm{ha}^{-1} \cdot \mathrm{dia}^{-1} ; 5^{\mathrm{a}}-20 \mathrm{~kg} \mathrm{MS} \cdot \mathrm{ha}^{-1} \cdot \mathrm{dia}^{-1}\right)$ com o início do período frio, com exceção a Lugão (2001) .

Doses de nitrogênio a partir de $756 \mathrm{~kg} \mathrm{~N} \cdot \mathrm{ha}^{-1}$.ano ${ }^{-1}$, proporcionaram como tendência as maiores taxas de acúmulo e produção de massa seca total (Figuras 27 a 29). Porém deve-se considerar atenção maior em encontrar a quantidade de nitrogênio que proporcionariam a máxima dose econômica, do que com os valores determinados de doses máximas de nitrogênio para máximas produções de massa seca potencial. Segundo Tisdale et al. (1985) a produção máxima é alvo nunca atingido, uma vez que aumenta constantemente com o aprimoramento tecnológico, mas já a produtividade máxima econômica deriva de análises econômicas dos resultados da pesquisa de produtividade máxima, e sendo representadas por adições um pouco inferiores de insumo, que resultam no maior lucro.

Uma outra ferramenta útil para discussão da produção de massa seca total é o uso do índice de produção de biomassa (IPB), porque permite a visão geral de comportamento das produções variando no tempo, e assim determinar claramente os efeitos de clima e dos tratamentos estudados. Os valores de IPB encontrados na Tabela 6, foram calculados usando as médias dos valores de produção de massa seca total , obtidos da interação tripla significativa de coleta, lâmina de irrigação e dose de nitrogênio, e obtidos na análise de variância da massa seca total. 
Observando-se individualmente, tanto os tratamentos com lâminas de irrigação, como a com o uso de nitrogênio (Tabela 16), durante todo o período experimental, observa-se que a ocorrência de estacionalidade na produção do capim Tanzânia em Piracicaba - SP é uma característica regional para o capim, sendo as coletas 5 e 6 as que apresentaram menor produção de massa seca, independentemente da lâmina ou dose de nitrogênio empregados. Isto vem confirmar as afirmações feitas anteriormente no texto.

Os valores de IPB tenderam a aumentar com o uso de adubação nitrogenada, e de maneira inversa ao aumento na lâmina irrigada (Tabela 16) no período de coleta quatro, onde as condições climáticas mostravam-se ainda favoráveis ao desenvolvimento do capim Tanzânia, com temperatura e precipitação. Isto é explicado por ser este o único período de coleta com efeito significativo de lâmina e de dose nitrogênio.

A diminuição dos valores de IPB apresentada pelas parcelas que não receberam adubação, durante o período de estudo (até $8^{\mathrm{a}}$ coleta) seria o indicativo de esgotamento do nitrogênio orgânico no solo, e , com a presença de novo período de crescimento a partir da $9^{a}$ coleta, existiria a possibilidade de aumento da degradação desta pastagem a partir do segundo ano de crescimento do capim.

\subsubsection{Produção de massa seca foliar e de hastes}

Os resultados das equações de regressão para variação de dose de adubação nitrogenada, nas três estações climáticas, para a massa seca foliar e de hastes, em pastagem de capim-Tanzânia encontram-se nas Tabelas de 17 a 18.

As produções de massa seca foliar previstas pelas equações de regressões, mostraram-se sempre menores que os valores previstos pela massa seca total, o que seria um indicativo de que a metodologia utilizada foi consistente, quando do uso de uma boa homogeneização do material pré-amostrado, e o número atual de amostras coletadas (3), mostram-se suficientes para a diminuição da variabilidade dos dados experimentais coletados no qual não foram suficientes para obtenção da interação tripla desejada (Anexos 2 e 3). 
Tabela 16. Índice de produção de biomassa (\%), estudado nas diferentes lâminas de irrigação e doses de nitrogênio em capim-Tanzânia, nos diferentes períodos de corte.

\begin{tabular}{|c|c|c|c|c|c|c|c|c|c|c|}
\hline \multirow{2}{*}{$\begin{array}{l}\text { Lâmina } \\
(\% \mathrm{CC})\end{array}$} & \multirow{2}{*}{$\begin{array}{c}\text { Dose N } \\
\text { (kgN/ha.ano) }\end{array}$} & \multicolumn{9}{|c|}{ Coleta } \\
\hline & & 1 & 2 & 3 & 4 & 5 & 6 & 7 & 8 & 9 \\
\hline \multirow{5}{*}{ 0 } & 0 & 55.6 & 10.2 & 9.0 & 6.8 & 5.0 & 2.9 & 1.5 & 1.5 & 7.0 \\
\hline & 100 & 36.3 & 19.1 & 13.9 & 9.2 & 5.6 & 3.5 & 2.8 & 1.6 & 7.7 \\
\hline & 275 & 28.9 & 15.9 & 11.0 & 8.9 & 6.0 & 3.0 & 5.7 & 6.5 & 13.6 \\
\hline & 756 & 21.5 & 13.4 & 9.3 & 14.0 & 5.1 & 3.2 & 5.0 & 7.4 & 20.7 \\
\hline & 2079 & 20.8 & 27.1 & 8.4 & 12.0 & 4.3 & 3.1 & 4.3 & 6.0 & 13.5 \\
\hline \multirow{5}{*}{30} & $\mathbf{0}$ & 32.9 & 17.7 & 16.1 & 12.0 & 2.8 & 4.2 & 2.6 & 3.9 & 7.0 \\
\hline & 100 & 26.8 & 11.2 & 22.4 & 16.3 & 4.9 & 3.2 & 3.9 & 2.4 & 8.5 \\
\hline & 275 & 21.3 & 14.7 & 14.5 & 11.1 & 4.9 & 4.1 & 6.4 & 6.9 & 15.2 \\
\hline & 756 & 20.6 & 20.6 & 10.1 & 12.7 & 4.6 & 4.4 & 5.4 & 8.3 & 13.1 \\
\hline & 2079 & 26.1 & 16.1 & 8.2 & 10.5 & 3.4 & 3.7 & 6.2 & 9.5 & 15.8 \\
\hline \multirow{5}{*}{70} & 0 & 33.1 & 14.6 & 9.8 & 16.2 & 7.1 & 3.7 & 3.0 & 3.0 & 9.1 \\
\hline & 100 & 30.7 & 16.7 & 9.8 & 14.9 & 3.1 & 2.6 & 5.6 & 6.6 & 9.6 \\
\hline & 275 & 30.4 & 14.9 & 12.9 & 10.9 & 4.4 & 3.2 & 4.8 & 5.3 & 12.4 \\
\hline & 756 & 21.7 & 13.9 & 11.7 & 13.5 & 3.5 & 4.1 & 7.0 & 10.7 & 13.6 \\
\hline & 2079 & 18.2 & 22.2 & 10.6 & 12.1 & 3.0 & 3.2 & 7.0 & 9.6 & 13.9 \\
\hline \multirow{5}{*}{100} & 0 & 35.7 & 5.1 & 15.3 & 18.4 & 6.7 & 2.8 & 3.3 & 3.6 & 8.4 \\
\hline & 100 & 26.3 & 14.3 & 16.1 & 14.8 & 3.2 & 3.0 & 3.7 & 3.3 & 15.0 \\
\hline & 275 & 21.9 & 16.2 & 16.2 & 14.1 & 2.6 & 3.4 & 5.9 & 7.2 & 12.1 \\
\hline & 756 & 20.4 & 17.8 & 8.7 & 11.1 & 3.6 & 3.4 & 5.5 & 11.8 & 17.9 \\
\hline & 2079 & 18.2 & 18.9 & 11.6 & 12.2 & 3.4 & 3.4 & 6.5 & 9.4 & 16.1 \\
\hline \multirow{5}{*}{150} & 0 & 34.1 & 16.0 & 15.2 & 6.9 & 4.7 & 3.0 & 5.7 & 2.8 & 11.1 \\
\hline & 100 & 36.9 & 14.5 & 6.9 & 11.9 & 4.4 & 2.6 & 4.2 & 4.3 & 13.9 \\
\hline & 275 & 21.4 & 18.6 & 10.9 & 12.9 & 3.8 & 4.8 & 6.9 & 7.5 & 12.9 \\
\hline & 756 & 15.1 & 17.2 & 13.0 & 11.4 & 3.7 & 3.3 & 8.6 & 11.8 & 15.4 \\
\hline & 2079 & 14.9 & 19.4 & 12.8 & 9.4 & 4.3 & 3.5 & 6.7 & 11.3 & 17.2 \\
\hline
\end{tabular}

A variação dos valores de produção de massa seca foliar, quando da não utilização de $\mathrm{N}$ (0 kg N.ha ${ }^{-1}$.ano $\left.{ }^{-1}\right)$ e de máxima produções observados na Tabela 17, durante os nove períodos de coletas, mostram a ocorrência da estacionalidade de produção em proporções semelhantes à massa seca total. 
As máximas doses de nitrogênio indicadas na Tabela 17, que proporcionam as maiores produções de massa seca foliar, mostraram a partir do estabelecimento dos ciclos de coletas $\left(4^{\mathrm{a}}\right)$, que menores quantidades de nitrogênio seriam necessários para obtenção de máxima produção de massa seca foliar, do que aquelas encontradas nas Tabelas 13 a 14 para massa seca total, o que seria explicado pelo aumento da fração haste na massa seca total .

Tabela 17 . Equações de regressão para variação de dose de nitrogênio dentro de cada coleta, nas três estações climáticas para a massa seca foliar em pastagem de capim-Tanzânia estabelecido numa Terra Roxa Estruturada, avaliados em área na Fazenda Areão, Piracicaba, SP.

\begin{tabular}{|c|c|c|c|c|c|}
\hline Estação & Coleta & Equação & $\mathrm{R}^{2}$ & $\operatorname{MPMS}^{(1)}$ & $\begin{array}{c}\text { Dose } \mathrm{N} \text { para } \\
\text { máxima } \\
\mathrm{MPMS}^{(2)}\end{array}$ \\
\hline \multirow{3}{*}{ Verão } & 1 & $2.852,31+0,51 \mathrm{X}$ & $0.85^{\text {*n- }}$ & 4.931 & 2.079 \\
\hline & 2 & $1.241,9+2,84 X-0,00073 X^{2}$ & $0,99^{* *}$ & 4.004 & 1.945 \\
\hline & 3 & $1.388,34+0,33 X$ & $0,71^{*}$ & 2.074 & 2.079 \\
\hline \multirow{3}{*}{ Inverno } & 4 & $659,53+1,05 X-0,00042 X^{2}$ & $0,89^{* * *}$ & 1.315 & 1.250 \\
\hline & 5 & $351,89+0,59 X-0,00022 X^{2}$ & $0,65^{*}$ & 747 & 1.340 \\
\hline & 6 & $178,64+0,71 X-0,00025 X^{2}$ & $0,97^{* *}$ & 682 & 1.420 \\
\hline \multirow{3}{*}{ Primavera } & 7 & $187,57+1,46 X+0,0005 X^{2}$ & $0,99^{* *}$ & 1.253 & 1.253 \\
\hline & 8 & $199,29+2,79 X-0,00094 X^{2}$ & $0,99^{* *}$ & 2.269 & 1.484 \\
\hline & 9 & $780,75+3,94 X-0,0013 X^{2}$ & $0,99^{* *}$ & 3.766 & 1.515 \\
\hline
\end{tabular}

Com o uso das doses de nitrogênio que permitiram as máximas produções (Tabela 17), as produções estimadas de massa seca foliar foram superiores a $71 \%$, $69 \%, 73 \%, 91 \%$ e $90 \%$ aos valores produzidos de massa seca de hastes (Tabela 18), entre as $5^{\mathrm{a}}$ e $9^{\mathrm{a}}$ coletas experimentais. A partir da ocorrência de condições climáticas 
favoráveis ao desenvolvimento do capim-Tanzânia, tem-se maior participação estimada de folhas dentro do material coletado no período de maior produção do capim.

Este aumento na participação das folhas dentro da massa seca total produzida, é discutida por Santos (1997) com relação a variação da relação folha:haste no capim Tanzânia e Mombaça, em quatro períodos de coletas. Maior relação de folha:haste ocorreu no período mais favorável ao crescimento do capim, e a menor quando decorrente da predominância de perfilhos reprodutivos; a autora sugere que para estes dois capins, deveria ser levada em consideração a relação folha:haste, para determinação do período de descanso, uma vez que controlando a participação das hastes na produção em algumas épocas do ano, seria mais importante do que maximizar a taxa de acúmulo líquido destes capins.

A quarta coleta apresentou quantidade estimada de massa seca foliar (1316 kg

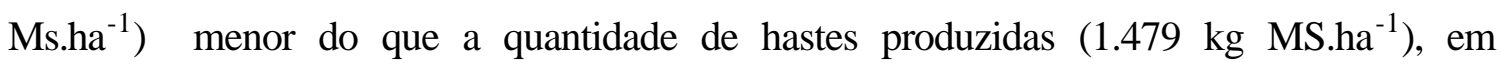
função da ocorrência do florescimento durante este período. $\mathrm{O}$ uso de doses altas de nitrogênio propiciaram estímulo ao florescimento mais uniforme e aumento na produção de sementes.

Nos trabalhos realizados por Pérez \& Pérez (1992) e de Joaquín et al. (2001) verifica-se que o uso de nitrogênio (doses acima de $150 \mathrm{~kg} \mathrm{~N} \cdot \mathrm{ha}^{-1}$.ano ${ }^{-1}$ ) efeito significativo na produção e na qualidade de sementes, onde fatores como porcentagem de pureza, vigor e rendimento de sementes puras responderam positivamente ao seu uso.

De modo geral, observando as Tabelas 17 e 18, tem-se predominância de equações quadráticas para os efeitos do nitrogênio na produção de massa seca foliar, e de equações lineares para estimativas de produções de massa seca de hastes. Assim, o uso de doses de nitrogênio além daquela considerada como ótima para a massa seca foliar, acima daqueles previstos na Tabela 17 , proporcionaria a participação de maior fração de material considerado haste (colmo, hastes, material senescido) na massa seca total, que poderiam apresentar menor valor nutritivo, e causariam possível redução geral na qualidade de pastagem oferecida aos animais em pastejo. 
Tabela 18. Equações de regressão para variação de dose de nitrogênio dentro de cada coleta, nas três estações climáticas para a massa seca de haste em pastagem de capim-Tanzânia estabelecida numa Terra Roxa Estruturada, avaliados na Fazenda Areão, Piracicaba, SP.

\begin{tabular}{|c|c|c|c|c|c|}
\hline Estação & Coleta & Equação & $\mathrm{R}^{2}$ & $\operatorname{MPMS}^{(1)}$ & $\begin{array}{c}\text { Dose } \mathrm{N} \text { para } \\
\text { máxima } \\
\mathrm{MPMS}^{(2)}\end{array}$ \\
\hline \multirow{3}{*}{ Verão } & 1 & $334,06+0,19 X$ & $0,85^{n+1}$ & 729,1 & $2.079,0$ \\
\hline & 2 & $77,54+0,48 X$ & $0.98^{* * *}$ & $1.075,5$ & $2.079,0$ \\
\hline & 3 & $167,49+0,11 X$ & $0,73^{@}$ & 396,2 & $2.079,0$ \\
\hline \multirow{3}{*}{ Inverno } & 4 & $494,62+1,21 X-0,00029 X^{2}$ & $0,96^{* *}$ & $1.758,8$ & $2.086,2$ \\
\hline & 5 & $84,70+0,094 X$ & $0,97^{*}$ & 279,9 & $2.079,0$ \\
\hline & 6 & $124,68+0,06 X$ & NS & 249,4 & $2.079,0$ \\
\hline \multirow{3}{*}{ Primavera } & 7 & $144,13+0,15 X$ & $0,89^{* * *}$ & 455,9 & $2.079,0$ \\
\hline & 8 & $16,29+0,13 X$ & $0,96^{* *}$ & 286,6 & $2.079,0$ \\
\hline & 9 & $1,69+0,24 X$ & $0,99^{* * *}$ & 500,7 & $2.079,0$ \\
\hline
\end{tabular}

\subsubsection{Produção de massa seca total, foliar e de hastes nas diferentes estações de coleta}

Os testes de médias para produção média de massa seca total, foliar e de haste entre as diferentes estações de coleta, isolados ou comparados dentro de cada dose de nitrogênio usada, estão presentes nas Tabelas 19 e 20. Estas tabelas foram obtidas do desdobramento da análise da variância mostrada na Tabela 4. 
Tabela 19. Variação de produção de massa seca total, foliar e de haste em três estações climáticas, em pastagem de capim-Tanzânia estabelecido numa Terra Roxa Estruturada, avaliados na Fazenda Areão, Piracicaba, SP.

\begin{tabular}{cccc}
\hline \multirow{2}{*}{ Estação } & \multicolumn{3}{c}{ Massa Seca $\left(\mathrm{kg} \mathrm{MS} \cdot \mathrm{ha}^{-1} \cdot\right.$ período $\left.^{-1}\right)$} \\
& Total & Foliar & Haste \\
\hline Verão & $2817,5^{\mathrm{a}}$ & $2466,9^{\mathrm{a}}$ & $358,9^{\mathrm{b}}$ \\
Inverno & $1031,2^{\mathrm{c}}$ & $602,1^{\mathrm{c}}$ & $429,1^{\mathrm{a}}$ \\
Primavera & $1384,6^{\mathrm{b}}$ & $1220,6^{\mathrm{b}}$ & $164,8^{\mathrm{c}}$ \\
DMS & 147,3 & 115,12 & 57,81 \\
\hline
\end{tabular}

* - Médias seguidas por letras distintas na mesma coluna, diferem entre si estatisticamente a $\mathrm{p}<0,05$

De maneira geral, as estações de inverno, primavera e verão mostram-se como a seqüência natural de aumento nas produção de massa seca total e de folhas, quando considerado o ciclo anual de crescimento o capim-Tanzânia. Exceção a esta sequiência refere-se a produção de massa seca de hastes, que apresentariam durante a estação do inverno a ocorrência do florescimento do capim Tanzânia (Tabelas 19 e 20).

O uso de dose de nitrogênio acima de $275 \mathrm{~kg} \mathrm{~N} \cdot \mathrm{ha}^{-1} . \mathrm{ano}^{-1}$ (ou $31 \mathrm{~kg} \mathrm{~N} \cdot \mathrm{ha}^{-}$ ${ }^{1}$.coleta $\left.{ }^{-1}\right)$, considerando a seqüência de produção de massa seca entre as estações de inverno ao verão, proporcionaram acréscimos nas produções de massa seca total e foliar, durante os períodos favoráveis ao crescimento do capim-Tanzânia, de aproximadamente $35 \%$ nas produções entre o inverno e primavera, e 52\% (275 kg N.ha ${ }^{-}$ ${ }^{1}$.ano ${ }^{-1}$ ) e $35 \%$ (756 e $2079 \mathrm{~kg} \mathrm{~N} \cdot \mathrm{ha}^{-1}$.ano ${ }^{-1}$ ) entre a primavera e o verão (Tabela 20).

Considerando as estações climáticas estudas, pode-se observar que o aumento da dose de nitrogênio, aumento nas produções de massa seca total e foliar (Tabela 20). 
Tabela 20. Variação de produção de massa seca total, foliar e de haste em três estações climáticas, dentro das diferentes doses de nitrogênio usadas, em pastagem de capim Tanzânia estabelecido numa Terra Roxa Estruturada, avaliados na Fazenda Areão, Piracicaba, SP.

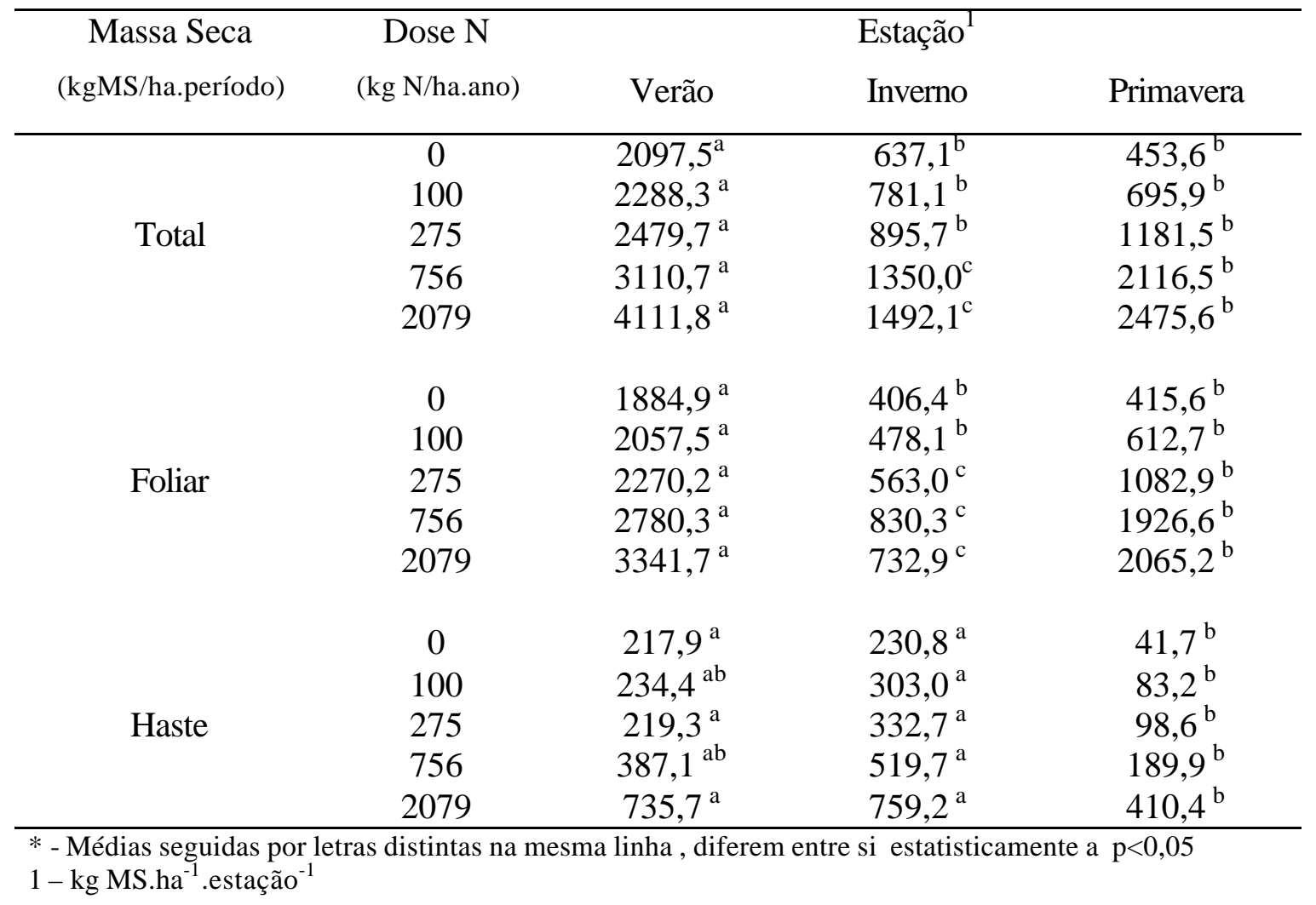

\subsubsection{Produção de massa seca dentro do ano agrícola de pastejo (2000/2001).}

O quadro da análise da variância e as equações de regressão dos efeitos significativos para a massa seca total, foliar e de haste, determinadas dos totais de produções obtidas durante todo o ciclo de pastejo estudado, são mostrados nas Tabelas 21 a 23. 
O efeito não significativo do uso das diferentes lâminas de irrigação na diferenciação de produção de massa seca da pastagem, como já discutido anteriormente, pode ser observado de forma mais clara nas Tabelas 22 e 23.

Quando considerado somente o estudo do efeito do uso das diferentes lâminas de irrigação na produção de massa seca total, observa-se efeito negativo do uso de água na produção de massa seca (Tabela 22), possivelmente causado pelos fatores já discutidos anteriormente.

Os valores de máxima produção de massa seca (MPMS) apresentados na Tabela 23, quando estudou-se o efeito das diferentes doses de nitrogênio, apresentaram-se com semelhantes de quanto às produções de massa seca total e foliar, e quando considerada cada lâmina de irrigação.

Devido ao efeito não significativo da lâmina de irrigação, as equações ajustadas (Tabela 22) para uso de nitrogênio, poderiam ser consideradas gerais para as produções anuais de massa seca total, foliar e de hastes.

Assim, as produções estimadas e apresentadas na Tabela 22 foram de 9.545, 11.195, 13.866 e $19.639 \mathrm{~kg} \mathrm{MS.ha}{ }^{-1}$.ano ${ }^{-1}$ para massa seca total, e de 8.125, 9.569, 11.869, 16710 e $18.808 \mathrm{~kg} \mathrm{MS} . \mathrm{ha}^{-1}$.ano ${ }^{-1}$ para massa seca foliar, quando utilizado zero, 100, 275, 756 e $2079 \mathrm{~kg} \mathrm{~N} \mathrm{ha}^{-1}$.ano $^{-1}$, respectivamente .

Com o uso da dose de nitrogênio determinada para MPMS (Tabela 22), e colocando-a como limite máximo de nitrogênio para a adubação do capim-Tanzânia neste experimento, encontrou-se que este nutriente proporcionou aumentos de produção em relação as parcelas não adubadas, da ordem aproximada de 15, 32, 106 e 167\% para massa seca total e foliar, em relação as doses 100, 275, 756 e $1.769 \mathrm{~kg} \mathrm{~N}^{\circ} \mathrm{ha}^{-1}$.ano ${ }^{-1}$

Os percentuais de incremento nas produções proporcionadas para cada uma destas dosagens de nitrogênio na massa seca total e foliar, foram de 15, 19, 29, $20 \%$ (16\% foliar), quando usadas doses 100, 275, 756 e $1.769 \mathrm{~kg} \mathrm{~N} \cdot \mathrm{ha}^{-1}$.ano ${ }^{-1}$. O que mostra que o uso dosagens de nitrogênio superiores a $756 \mathrm{Kg} \mathrm{N}_{\mathrm{n}} \mathrm{ha}^{-1}$.ano ${ }^{-1}$ não mais proporcionaram efeitos positivos sobre a produção de massa seca em planta de capimTanzânia. 
Tabela 21. Análise da variância da massa seca total, folha e haste dentro de um ciclo agrícola de pastejo (21/11/2000 a 14/11/2001).

\begin{tabular}{|c|c|c|c|c|c|c|c|}
\hline \multirow{3}{*}{ Causas de Variação } & \multirow{3}{*}{ G.L. } & \multicolumn{6}{|c|}{ Massa Seca (kg MS/Ha. Ano } \\
\hline & & \multicolumn{2}{|c|}{ TOTAL } & \multicolumn{2}{|c|}{ FOLHA } & \multicolumn{2}{|c|}{ HASTE } \\
\hline & & Q.M. & $\mathrm{F}$ & Q.M. & $\mathrm{F}$ & Q.M. & $\mathrm{F}$ \\
\hline Bloco & 2 & - & - & - & - & - & - \\
\hline Lamina & 4 & $16.133 .969,2$ & $3,21^{@}$ & $6.366 .822,9$ & $3,77^{*}$ & $3.445 .360,42$ & $2,08^{\mathrm{NS}}$ \\
\hline RESIDUO (A) & 8 & $5.015 .789,3$ & - & $1.689 .748,4$ & - & $1.652 .699,96$ & - \\
\hline PARCELAS & 14 & - & - & - & - & - & - \\
\hline Dose $\mathrm{N}$ & 4 & $563.682 .710,1$ & $99,36^{* * *}$ & $313.754 .666,8$ & $87.08^{* * *}$ & $41.986 .568,0$ & $32,89^{* * *}$ \\
\hline Lam*Dos & 16 & $15.790 .808,4$ & $2,78^{* *}$ & $9.681 .129,6$ & $2,68^{*}$ & $1.270 .719,9$ & $0,99^{\mathrm{NS}}$ \\
\hline RESIDUO (B) & 40 & $5.673 .131,7$ & - & $3.602 .937,1$ & - & $1.276 .405,9$ & - \\
\hline TOTAL & 74 & - & - & - & - & - & - \\
\hline
\end{tabular}

Tabela 22. Equações de regressão para diferentes lâminas de irrigação e dose de nitrogênio, para a massa seca total, foliar e de haste dentro de um ciclo agrícolas de pastejo, em um pastagem de capim-Tanzânia estabelecido numa Terra Roxa Estruturada, avaliados na Fazenda Areão, Piracicaba, SP.

\begin{tabular}{cccccc}
\hline \multirow{2}{*}{ Efeito } & MS $^{1}$ & Equação & $\mathrm{R}^{2}$ & $\mathrm{MPMS}^{(2)}$ & $\begin{array}{c}\text { Lâmina ou } \\
\text { Dose N para } \\
\text { MPMS }^{(3)}\end{array}$ \\
\hline \multirow{2}{*}{ Lâmina } & Total & $16.772,79-15,32 \mathrm{X}$ & $0.75^{*}$ & 16.773 & 0 \\
& Folha & $\mathrm{NS}$ & - & - & - \\
& Haste & $\mathrm{NS}$ & - & - & - \\
& Total & $9.545,35+16,98 \mathrm{X}-0,0048 \mathrm{X}^{2}$ & $0,99^{* *}$ & 24.563 & 1.769 \\
\multirow{2}{*}{ Nitrogênio } & Folha & $8.125,12+14,91 \mathrm{X}-0,0047 \mathrm{X}^{2}$ & $0,99^{* *}$ & 19.950 & 1.586 \\
& Haste & $1.442,55+1,95 \mathrm{X}$ & $0,99^{* *}$ & 5.497 & 2.079 \\
\hline
\end{tabular}

1- Massa Seca; .2 - MPMS - Máxima produção de massa seca (kg MS/ha.ano); 3 - kg N/ha .ano .

$\star \mathrm{p}<0,05 ; * \star \mathrm{p}<0,01 ; \mathrm{NS}-\mathrm{Não} \mathrm{significativo}$ 
Tabela 23. Equações de regressão para variação de dose de nitrogênio dentro de cada lâmina de irrigação usada, para a massa seca total, foliar e de haste dentro de um ciclo agrícola de pastejo, em pastagem de capim-Tanzânia estabelecido numa Terra Roxa Estruturada na Fazenda Areão, Piracicaba, SP.

\begin{tabular}{|c|c|c|c|c|c|}
\hline Composição & Lâmina $^{1}$ & Equação & $\mathrm{R}^{2}$ & $\operatorname{MPMS}^{(2)}$ & $\begin{array}{c}\text { Dose } \mathrm{N} \text { para } \\
\text { máxima } \\
\mathrm{MPMS}^{(3)}\end{array}$ \\
\hline \multirow{5}{*}{ Total } & 0 & $11.912,87+12,32 X-0,00305 X^{2}$ & $0.99^{*}$ & $24.354,05$ & $2.019,67$ \\
\hline & 30 & $10.473,03+16,72 X-0,00548 X^{2}$ & $0,71^{* *}$ & $23.226,61$ & $1.525,55$ \\
\hline & 70 & $9.910,13+17,19 X-0,00446 X^{2}$ & $0,95^{* *}$ & $26.473,81$ & $1.927,13$ \\
\hline & 100 & $8.347,97+18.95 X-0,00446 X^{2}$ & $0,94^{* *}$ & $24.379,33$ & $1.691,96$ \\
\hline & 150 & $7.082,71+19,73 X-0,00560 X^{2}$ & $0,99^{* *}$ & $24.460,91$ & $1.761,61$ \\
\hline \multirow{5}{*}{ Folha } & 0 & $9.746,39+11,35 X-0,0036 X^{2}$ & $0,99^{* *}$ & $18.692,40$ & $1.576,38$ \\
\hline & 30 & $8.793,51+13,89 X-0,0046 X^{2}$ & $0,73^{*}$ & $19.278,95$ & $1.509,78$ \\
\hline & 70 & $8.657,36+14,74 X-0,0043 X^{2}$ & $0,93^{* *}$ & $21.289,10$ & $1.713,95$ \\
\hline & 100 & $7.064,65+16,68 X-0,0052 X^{2}$ & $0,93^{* *}$ & $20.440,73$ & $1.603,85$ \\
\hline & 150 & $6.363,69+17,84 X-0,0057 X^{2}$ & $0,99^{* *}$ & $20.322,70$ & $1.564,91$ \\
\hline \multirow{5}{*}{ Haste } & 0 & NS & - & - & - \\
\hline & 30 & NS & - & - & - \\
\hline & 70 & NS & - & - & - \\
\hline & 100 & NS & - & - & - \\
\hline & 150 & NS & - & - & - \\
\hline
\end{tabular}

$\star \mathrm{p}<0,05 ; * \star \mathrm{p}<0,01 ; * \star \star \mathrm{p}<0,001 ; \mathrm{NS}-$ Não significativo

1 - \% da capacidade de campo; 2 -. MPMS - Máxima produção de massa seca (kg MS/ha.ano) ; 3 - kg N/ha .ano .

Quando do uso da máxima dose de nitrogênio indicada na Tabela 22, obteve-se produção de massa seca total máxima de 24.562,75 kg de ${\mathrm{MS} . h a^{-1} \text {.ano }}^{-1}$ para capim Tanzânia, valor que foi inferior aquele encontrado por Vicente-Chandler et al. (1962), que trabalhando com o capim Guiné (Panicum maximum) encontraram $35.000 \mathrm{~kg}$ de MS.ha $^{-1}$.ano ${ }^{-1}$, em 6 cortes a cada 60dias, o que permitiu produção média de $5.833 \mathrm{~kg}$ de MS.ha ${ }^{-1} \cdot$ corte $^{-1}$ ou taxa de acúmulo de $97 \mathrm{~kg} \mathrm{MS} \cdot \mathrm{ha}^{-1} \cdot \mathrm{dia}^{-1}$. 
Comparando trabalhos nesta linha de pesquisa, quanto à altura de corte e ao uso do nitrogênio, as respostas obtidas neste experimento (13.490 e $16.214 \mathrm{~kg}$ de MS. ha ${ }^{-1}$. 324 dias, com 250 e $450 \mathrm{~kg} \mathrm{Nha}^{-1}$.ano ${ }^{-1}$ ) foram inferiores aquelas obtidas por Rosseto (2000) em capim-Tanzânia, com aplicação de $250 \mathrm{~kg}$ de N.ha ${ }^{-1} \cdot$ ano $^{-1} \quad(20.806 \mathrm{~kg}$ de MS.ha $^{-1} .214$ dias $^{-1}$ ), e por Lugão (2001) com Panicum maximum.(acesso BRA-006998) sob lotação rotacionada, com a aplicação de $450 \mathrm{~kg} \mathrm{~N} \cdot \mathrm{ha}^{-1}$.ano ${ }^{-1}$ (31.019 kg de MS.ha ${ }^{-}$ ${ }^{1} .200 \mathrm{dias}^{-1}$ ). Considerando que este dois experimentos foram implantados em solo classificado como Latossolo (Vermelho para por Rosseto (2000) e Vermelho-Amarelo Lugão (2001), que apresentam características físicas diferentes da Terra Roxa Estruturada usada neste experimento, onde característica de textura (argilosa e muito argilosa) e de porosidade (principalmente de macroporos), podem ter sido fatores importantes para a limitação no desenvolvimento do capim-Tanzânia nesta pesquisa.

\section{5 Índices relacionados a produção de massa seca.}

Os dados apresentados serão discutidos com base na tendência de comportamento do capim-Tanzânia, em função dos valores médios de produção de massa seca total para a determinação de diferentes índices, e por serem os resultados de $\mathrm{N}$ total de cada tratamento, resultantes da mistura de plantas dos três blocos experimentais (redução de custos das análises laboratoriais).

Os índices estudados foram: eficiência de uso de água (EUA), eficiência de uso do nitrogênio (EUN), eficiência fisiológica de nitrogênio absorvido (EFNabs) e nitrogênio aparente recuperado (NapRec), que são apresentados nas Tabelas 24 a 31 .

\subsubsection{Eficiência de uso de água ( EUA)}

O consumo de água em cada período de coleta e as eficiências de uso da água (EUA) considerando somente o efeito da lâmina de irrigação e de sua interação com o uso de nitrogênio encontram-se nas Tabelas 24 a 26 e nas Figuras 30 e 31. 
Tabela 24. Quantidade geral de água consumida (mm) em cada lâmina de irrigação, e nos diferentes períodos de coleta, pelo capim Tanzânia,.

\begin{tabular}{cccccc}
\hline Coleta & 0 & 30 & 70 & 100 & 150 \\
\hline 1 & 77,47 & 77,62 & 77,80 & 78,00 & 77,80 \\
2 & 87,46 & 89,30 & 89,90 & 90,10 & 90,04 \\
3 & 64,10 & 68,10 & 71,70 & 73,30 & 74,80 \\
4 & 37,10 & 48,50 & 59,40 & 65,00 & 66,60 \\
5 & 14,44 & 18,10 & 24,10 & 27,76 & 30,10 \\
6 & 22,65 & 29,00 & 37,90 & 41,30 & 44,80 \\
7 & 36,10 & 47,40 & 56,20 & 61,10 & 61,80 \\
8 & 60,30 & 66,40 & 69,80 & 71,30 & 73,10 \\
9 & 61,64 & 73,40 & 86,10 & 93,50 & 97,22 \\
Total & 461,26 & 517,82 & 572,9 & 601,36 & 616,26 \\
\hline
\end{tabular}

Dentro da discussão geral sobre o consumo de água em cada período de crescimento experimental, observa-se que nos períodos em que as plantas tinham maior disponibilidade de água para o seu desenvolvimento (coleta 1, 2 e 9) (Figura 30) o consumos de água pelas plantas apresentaram-se semelhantes em todas lâminas estudadas (Tabela 24), sendo que com o aumento das lâminas de irrigação observaramse maiores perdas de água no sistema, o que poderia corroborar com maiores perdas de nitrogênio no sistema, através de lixiviação ou desnitrificação (Dodd et al., 2000).

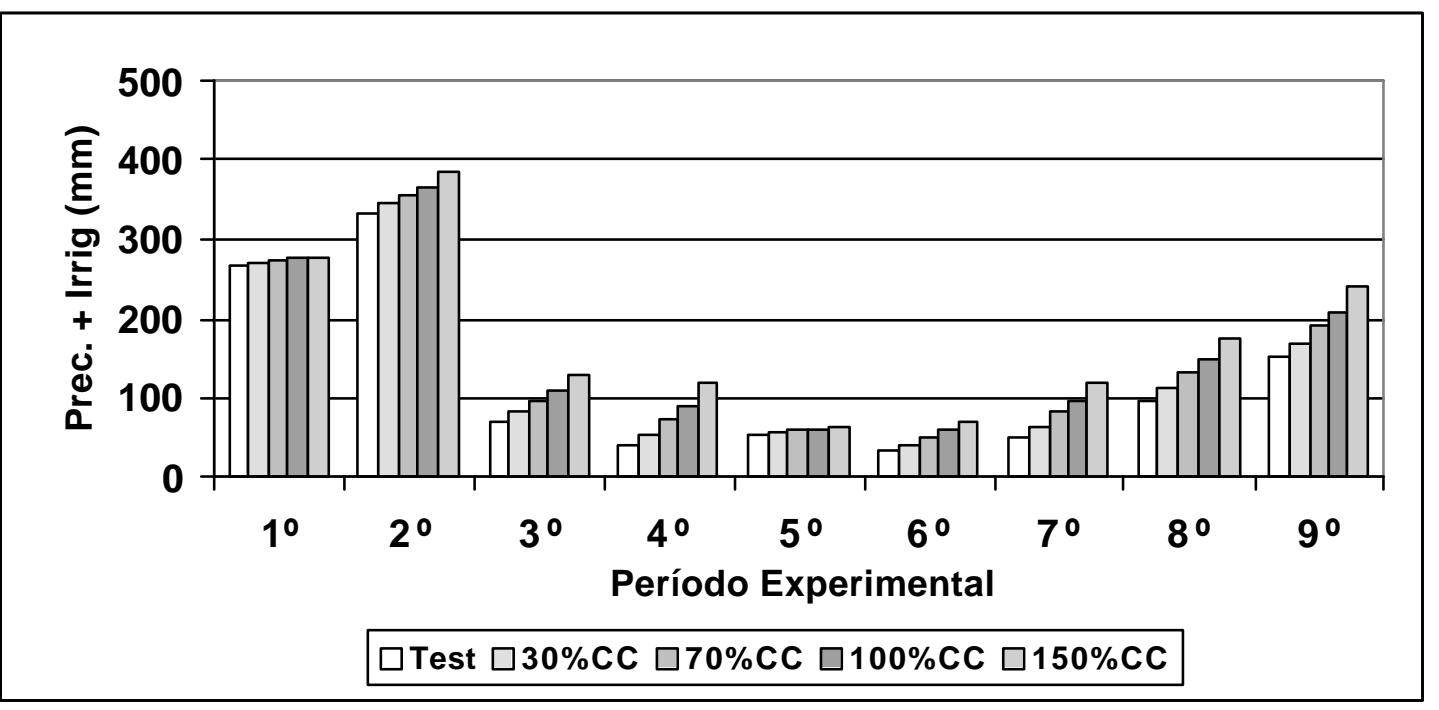

Figura 30 - Quantidade total de água disponível (mm) para as plantas de capim Tanzânia, durante todo período de coleta experimental em estudo. 
O não aproveitamento desta água disponível, foram as maiores dentro todos os períodos de coleta estudados, onde perdas médias por percolação no solo foram próximos a 195, 267 e $108 \mathrm{~mm}$ durante estes três períodos de coletas (coleta 1, 2 e 9), uma vez que o escorrimento superficial não foi quantificado e observado na área experimental coberta com o capim-Tanzânia.

Nas terceira e quarta coletas, com o início do período mais favorável ao estudo do efeito das diferentes lâminas de irrigação (temperatura, fotoperíodo e "déficit" hídrico), diferenciação no consumo pode ser observada (Tabela 24), ou seja onde tem-se maior consumo com o aumento da lâmina de irrigação. $O$ uso de lâminas de irrigação acima de $100 \%$ da capacidade de campo, proporcionaram valores semelhantes de consumo de água entre sí.

Considerando os valores de lâminas de água oferecidas às plantas ( Figura 9) durante os demais períodos de coleta (5 a 8), estas foram sempre superiores ás necessidades das plantas. Com o início da estacionalidade e do inverno (coleta 5), o consumo de água caiu de maneira significativa (Tabela 24), parecendo que neste primeiro momento de frio, as plantas são mais sensíveis a esta mudança climática, causada pela diminuição da temperatura. Este menor aproveitamento da água disponível para a pastagem, pode ser observada pelo menor consumo de água (Tabela 24) e pela disponibilidade hídrica no período, que foi em média de $58 \mathrm{~mm}$ para as diferentes lâminas de irrigação empregadas, o que mostraria perda por percolação significativa também neste período.

O consumo de água a partir da sexta coleta aumentou dentro das diferentes lâminas de irrigação, com o aumento da temperatura (Tabela 24).

Observando a tendência de variação dos valores de EUA dentro das diferentes lâminas de irrigação aplicadas (Figura 31 - A), encontra-se redução nos valores EUA com o aumento da lâmina de irrigação, sendo que a partir de $70 \%$ da capacidade de campo, os valores de EUA diminuem com as maiores lâminas usadas, o que poderia causar maior percolação e lixiviação de nutrientes. 
Stout et al. (1988), trabalhando com duas gramíneas em condições de semi-árido, estudando o efeito do uso de nitrogênio em solos com diferentes capacidades de armazenamento de água e EUA, comentam que o indicativo de propriedades do solo relacionadas à capacidade de armazenamento de água (estrutura, textura, densidade do solo, porcentagem e tipo de areia) podem ser usados juntos com dados climáticos históricos, no desenvolvimento de modelos que poderiam predizer produções potenciais para este e outros solos, quando do uso ou não de nitrogênio. A determinação da curva de retenção de água no solo em diferentes profundidades do perfil, visando identificar a capacidade de armazenamento de água do solo, passa a ser uma prática importante em áreas de pastagem no qual pretende-se fazer uso de irrigação ou melhor compreender o efeito de estiagens na produção de sequeiro ou não.

Outra maneira de apresentação da EUA, é pela determinação da quantidade de água necessária às plantas, para a produção de determinada quantidade (nesse caso , 1 tonelada) de massa seca (Figura 31 - B), como apresentados por Fardad \& Pessarakli. (1995) em plantas de cevada e trigo.

Observando a Figura 31 - B, as quantidades de água necessárias para a produção de massa seca aumentaram, como tendência, até o tratamento visando repor a umidade no solo a $100 \%$ de sua capacidade de campo, sendo que a partir desse ponto não mais diferiram.

Este aumento no consumo de água com o aumento da lâmina de irrigação, mostram que as plantas de capim-Tanzânia tiveram períodos de limitação de água durante o seu crescimento. Entende-se por isto, como sendo variação de diferentes lâminas e freqüência de ocorrência, de cada tratamento.

Em condições de baixa disponibilidade de água no solo, as plantas tendem a transpirar menos, o que sugere que as plantas dentro de condição de estresse utilizem diferentes mecanismos de ajuste visando transpor o período adverso. 

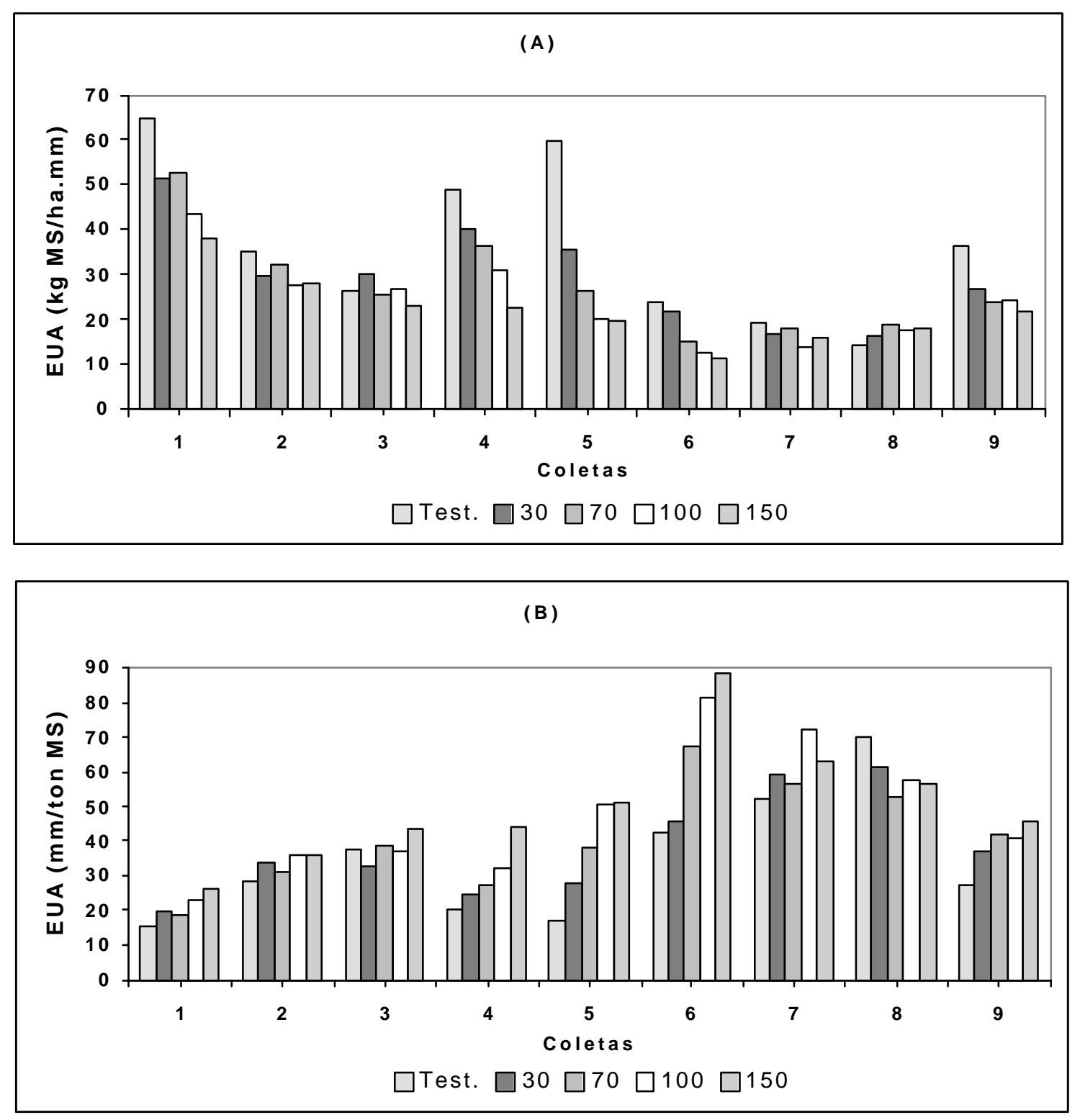

Figura 31 - Média das eficiência de uso da água - EUA ( A - kg MS. $\mathrm{ha}^{-1} \cdot \mathrm{mm}^{-1}$ de $\mathrm{H}_{2} \mathrm{O}$ absorvida; $\mathrm{B}-\mathrm{mm} \mathrm{H}_{2} \mathrm{O}$ necessários. produção de 1 ton. de $\mathrm{MS}^{-1}$ ) determinadas para diferentes lâminas de irrigações usadas, em plantas de capim-Tanzânia, durante todo período experimental .

A importância da deficiência hídrica pode ser avaliada através do primeiro sintoma observado nas plantas, que seria a redução da taxa de alongamento celular, que é um dos parâmetros fisiológicos mais sensíveis à falta de água, e com a perda do turgor 
da células foliares tem-se imediata interrupção do processo de elongação (Rodrigues \& Rodrigues, 1987; Taiz \& Zeiger, 1998). Associado a esta redução na taxa de desenvolvimento de órgãos e elongamento celular, outros efeitos indiretos passam a ocorrer, como a redução na fotossíntese (síntese de carboidratos e proteínas), diminuição na área foliar, absorção de nutrientes e por fimm na produção final de massa seca (Slatyer, 1969; Eastin \& Sullivan, 1984) .

Diminuição na absorção de nutrientes é freqüentemente observada quando a planta sofre um estresse hídrico no solo, o qual acaba por retardar alguns aspectos de crescimento e desenvolvimento durante esta imposição a falta de água (Slatyer, 1969), principalmente deficiência de nitrogênio, fósforo e potássio, que são importantes por participarem na síntese de proteínas e na fotossíntese, que acabam reduzindo valores de EUA (Tabela 25) durante todo o ciclo de crescimento das plantas.

Comparando a tendência de variação temporal dos valores de EUA e observando somente os efeitos das diferentes lâminas apresentadas na Tabela 25, o tratamento que visou repor a umidade no solo a $70 \%$ de sua capacidade de campo mostrou ser o que proporcionou os maiores valores de EUA com a irrigação suplementar. Observa-se que o quarto período de coleta apresentou maiores valores de EUA em relação às demais coletas, o que estaria relacionado com a diminuição da precipitação e a presença de condições climáticas favoráveis para o desenvolvimento do capim.

O efeito do uso do nitrogênio no aumento dos valores de EUA, tem sido bastante estudado em gramíneas forrageiras ( Power, 1980a ; Power, 1985; Stout et al., 1988; Stout, 1992; Dias Filho et al., 1992 e Asseng et al., 2001). No geral, o uso de fertilizante nitrogenado aumenta a EUA, que por associação é aumentado em função do efeito do aumento na produção de massa seca , e segundo encontrado por Power (1980a), existiria quase relação linear entre a EUA e produção de massa seca, quando este trabalhou com algumas gramíneas perenes. Power (1985) comenta que esta relação, não apresentaria influência do tipo de espécie estudada, como também a época de coleta.

Dias Filho et al. (1992), trabalhando com Panicum maximum. cv. Tobiatã em condição de estresse, relatam que a produção de massa seca foi reduzida quando as plantas encontravam-se sob estresse hídrico, e consequentemente maiores produções em 
plantas não estressada que receberam maiores doses de nitrogênio, foram em parte explicadas, pela maior transpiração potencial destas plantas.

Tabela 25. Eficiência de uso de água $\left(\mathrm{kg} \mathrm{MS} \cdot \mathrm{ha}^{-1} \cdot \mathrm{mm}^{-1}\right)$, estudado nas diferentes lâminas de irrigação e doses de nitrogênio em capim-Tanzânia, nos diferentes períodos de corte.

\begin{tabular}{|c|c|c|c|c|c|c|c|c|c|c|}
\hline \multirow{2}{*}{ Lâmina $^{1}$} & \multirow{2}{*}{$\mathrm{N}^{2}$} & \multicolumn{9}{|c|}{ Coletas } \\
\hline & & 1 & 2 & 3 & 4 & 5 & 6 & 7 & 8 & 9 \\
\hline \multirow{5}{*}{ 0 } & 0 & 86,0 & 14,0 & 16,9 & 22,0 & 42,1 & 15,8 & 5,0 & 3,1 & 13,7 \\
\hline & 100 & 60,3 & 28,2 & 27,9 & 32,1 & 50,1 & 20,0 & 10,1 & 3,6 & 16,1 \\
\hline & 275 & 57,3 & 27,9 & 26,4 & 36,9 & 64,1 & 20,8 & 24,5 & 16,7 & 34,1 \\
\hline & 756 & 54,0 & 29,8 & 28,3 & 73,5 & 69,6 & 27,5 & 27,0 & 24,0 & 65,2 \\
\hline & 2079 & 65,3 & 75,7 & 32,2 & 79,2 & 72,6 & 33,8 & 29,4 & 24,3 & 53,6 \\
\hline \multirow{5}{*}{30} & 0 & 59,2 & 27,7 & 34,0 & 34,7 & 21,6 & 20,6 & 7,7 & 8,2 & 13,3 \\
\hline & 100 & 37,7 & 13,6 & 35,9 & 36,7 & 29,8 & 12,1 & 9,0 & 4,0 & 12,7 \\
\hline & 275 & 28,0 & 16,8 & 21,7 & 23,5 & 27,6 & 14,7 & 13,9 & 10,6 & 22,0 \\
\hline & 756 & 59,5 & 51,9 & 33,4 & 58,9 & 57,3 & 34,1 & 25,5 & 28,0 & 40,1 \\
\hline & 2079 & 71,7 & 38,5 & 25,9 & 46,4 & 40,8 & 27,4 & 28,1 & 30,6 & 45,8 \\
\hline \multirow{5}{*}{70} & 0 & 33,1 & 12,6 & 10,7 & 21,2 & 23,2 & 7,6 & 4,2 & 3,4 & 8,3 \\
\hline & 100 & 54,9 & 26,0 & 19,2 & 35,1 & 18,0 & 9,6 & 14,0 & 13,2 & 15,6 \\
\hline & 275 & 57,5 & 24,4 & 26,6 & 27,0 & 27,2 & 12,6 & 12,7 & 11,2 & 21,9 \\
\hline & 756 & 55,1 & 30,6 & 32,2 & 44,8 & 29,2 & 21,7 & 24,8 & 30,3 & 30,8 \\
\hline & 2079 & 61,9 & 65,9 & 39,2 & 53,9 & 33,6 & 22,6 & 33,0 & 36,4 & 42,0 \\
\hline \multirow{5}{*}{100} & 0 & 31,4 & 3,9 & 14,3 & 19,5 & 16,6 & 4,7 & 3,8 & 3,5 & 6,3 \\
\hline & 100 & 34,6 & 16,3 & 22,6 & 23,4 & 11,8 & 7,6 & 6,4 & 4,7 & 16,5 \\
\hline & 275 & 44,3 & 28,5 & 35,0 & 34,4 & 15,2 & 13,3 & 15,3 & 15,9 & 20,4 \\
\hline & 756 & 48,1 & 36,4 & 22,0 & 31,6 & 23,8 & 15,1 & 16,7 & 29,1 & 35,3 \\
\hline & 2079 & 59,0 & 53,1 & 40,2 & 47,4 & 31,6 & 20,9 & 27,0 & 33,3 & 43,5 \\
\hline \multirow{5}{*}{150} & 0 & 32,0 & 13,0 & 14,9 & 7,6 & 11,5 & 5,0 & 6,8 & 2,8 & 8,4 \\
\hline & 100 & 40,6 & 13,8 & 7,9 & 15,3 & 12,6 & 5,1 & 5,9 & 5,1 & 12,2 \\
\hline & 275 & 34,1 & 25,6 & 18,2 & 24,0 & 15,6 & 13,2 & 14,0 & 12,8 & 16,4 \\
\hline & 756 & 36,6 & 35,9 & 32,8 & 32,3 & 23,6 & 14,0 & 26,1 & 30,4 & 29,7 \\
\hline & 2079 & 45,9 & 51,5 & 41,1 & 33,9 & 34,7 & 19,1 & 26,2 & 37,2 & 42,4 \\
\hline
\end{tabular}

1-( porcentagem da capacidade de campo - \%CC) ; 2 - (kgN/ha.ano) .

Stout (1992), trabalhando com Panicum virgatum L. cv. Cave-n-Rock no nordeste do Estados Unidos, em solos que apresentam como características baixa disponibilidade de água, encontrou que a EUA foi significativamente afetada pela fertilização nitrogenada e pelo tipo de solo, no qual a EUA variou diretamente com a disponibilidade de água e capacidade de armazenamento no solo

Asseng et al. (2001) fazendo uso de modelagem (APSIM) para estudar a eficiência de uso de água e nitrogênio em trigo no clima Mediterrâneo (média de 400 $\mathrm{mm}$ ano), mostram que a variabilidade sazonal, atribuídas pelos efeitos das 
precipitações e sua distribuição durante a estação de crescimento, teriam papel importante na EUA e EUN (eficiência de uso do nitrogênio), quando considerando o tipo de solo usado. Diferenças nas capacidades de armazenamento de água no solo em texturas diferentes (argilosos e arenoso), evaporação do solo e a interação destes fatores teriam amplo impacto sobre a EUA e EUN.

Observando-se os valores de EUA nas diferentes doses de nitrogênio, dentro de cada lâmina estabelecida (Tabela 25), encontra-se para os sucessivos cortes experimentais nas sub-parcelas sem adubação, redução dos valores de EUA com o aumento da lâmina de irrigação usada, possivelmente causada pela lixiviação do $\mathrm{N}$ e de outros nutrientes essenciais pelo perfil do solo.

O tratamento que usou $50 \%$ a mais de sua capacidade de campo (150\% CC) tendeu a apresentar menores valores de EUA comparando aos demais tratamentos durante a quarta coleta, o qual poderia ser decorrente de maior lixiviação do nitrogênio aplicado no solo (efeito deletério da irrigação excessiva), ou mudança da porcentagem de aeração devido a diminuição na porosidade no solo.

Na Tabela 26 a EUA, dada em quantidade de água necessária às plantas para a produção de uma determinada quantidade de massa seca, mostram que com a variação da dose de nitrogênio dentro de cada lâmina de irrigação utilizada, observa-se que os valores de EUA diminuem com o uso de nitrogênio durante todos períodos de coleta experimental (Tabela 26), sendo que nos períodos de maior déficit hídrico (coleta 6 e 7), observaram-se os maiores valores de EUA.

Asseng et al. (2001) em modelagem com trigo, encontraram que pequenos aumentos na fertilização com nitrogênio teriam permitido maiores incrementos em EUN e EUA em simulações, onde aumentos de EUA de 0,82 para 1,09 g. $\mathrm{m}^{-2} \cdot \mathrm{mm}^{-1}$ com o uso de $3 \mathrm{~g} \mathrm{~N} . \mathrm{m}^{-2}$ no oeste da Austrália. Medições em 5 estações feitas por Zhang et al. (1998) mostraram que o efeito positivo do uso do nitrogênio sobre a EUA, variou com o suplemento de água no solo, e que poderia ser marginal em estações de baixa pluviosidade. 
Tabela 26. Eficiência de uso de água (mm.ton $\mathrm{MS}^{-1} \cdot \mathrm{ha}^{-1}$ ), estudado nas diferentes lâminas de irrigação e doses de nitrogênio em capim-Tanzânia, nos diferentes períodos de corte.

\begin{tabular}{|c|c|c|c|c|c|c|c|c|c|c|}
\hline Lâmina $^{1}$ & $\mathrm{~N}^{2}$ & 1 & 2 & 3 & 4 & $\begin{array}{c}\text { Coletas } \\
5\end{array}$ & 6 & 7 & 8 & 9 \\
\hline \multirow{5}{*}{0} & 0 & 11,6 & 71,3 & 59,2 & 45,5 & 23,8 & 63,3 & 198,8 & 321,3 & 72,9 \\
\hline & 100 & 16,6 & 35,4 & 35,8 & 31,2 & 19,9 & 49,9 & 99,3 & 280,6 & 62,1 \\
\hline & 275 & 17,5 & 35,8 & 37,9 & 27,1 & 15,6 & 48,0 & 40,7 & 60,0 & 29,4 \\
\hline & 756 & 18,5 & 33,6 & 35,4 & 13,6 & 14,4 & 36,4 & 37,0 & 41,6 & 15,3 \\
\hline & 2079 & 15,3 & 13,2 & 31,0 & 12,6 & 13,8 & 29,6 & 34,0 & 41,1 & 18,6 \\
\hline \multirow{5}{*}{30} & 0 & 16,9 & 36,1 & 29,4 & 28,8 & 46,4 & 48,5 & 130,2 & 122,1 & 75,2 \\
\hline & 100 & 26,6 & 73,3 & 27,9 & 27,3 & 33,6 & 82,5 & 111,0 & 252,6 & 78,9 \\
\hline & 275 & 35,8 & 59,5 & 46,0 & 42,5 & 36,2 & 68,1 & 72,1 & 94,2 & 45,6 \\
\hline & 756 & 16,8 & 19,3 & 30,0 & 17,0 & 17,5 & 29,4 & 39,1 & 35,7 & 24,9 \\
\hline & 2079 & 13,9 & 26,0 & 38,7 & 21,6 & 24,5 & 36,5 & 35,6 & 32,6 & 21,8 \\
\hline \multirow{5}{*}{70} & 0 & 30,2 & 79,1 & 93,7 & 47,1 & 43,2 & 131,6 & 240,0 & 295,3 & 120,8 \\
\hline & 100 & 18,2 & 38,5 & 52,2 & 28,5 & 55,6 & 103,8 & 71,7 & 75,5 & 64,1 \\
\hline & 275 & 17,4 & 41,0 & 37,6 & 37,1 & 36,8 & 79,3 & 79,0 & 88,9 & 45,6 \\
\hline & 756 & 18,1 & 32,6 & 31,1 & 22,3 & 34,2 & 46,2 & 40,3 & 33,0 & 32,5 \\
\hline & 2079 & 16,2 & 15,2 & 25,5 & 18,6 & 29,7 & 44,2 & 30,3 & 27,5 & 23,8 \\
\hline \multirow{5}{*}{100} & 0 & 31,8 & 254,6 & 69,8 & 51,3 & 60,2 & 214,1 & 242,0 & 282,6 & 157,9 \\
\hline & 100 & 28,9 & 61,4 & 44,2 & 42,7 & 84,5 & 130,9 & 144,4 & 210,6 & 60,7 \\
\hline & 275 & 22,6 & 35,1 & 28,6 & 29,1 & 65,7 & 75,3 & 60,1 & 62,8 & 49,0 \\
\hline & 756 & 20,8 & 27,5 & 45,4 & 31,7 & 42,0 & 66,1 & 55,2 & 34,4 & 28,3 \\
\hline & 2079 & 16,9 & 18,8 & 24,9 & 21,1 & 31,7 & 47,8 & 34,0 & 30,0 & 23,0 \\
\hline \multirow{5}{*}{150} & 0 & 31,2 & 77,1 & 67,2 & 132,1 & 87,1 & 198,6 & 146,3 & 350,9 & 119,4 \\
\hline & 100 & 24,6 & 72,3 & 126,7 & 65,2 & 79,4 & 197,4 & 169,0 & 196,5 & 81,7 \\
\hline & 275 & 29,3 & 39,1 & 55,0 & 41,7 & 64,1 & 75,5 & 71,7 & 78,0 & 60,8 \\
\hline & 756 & 27,3 & 27,9 & 30,5 & 31,0 & 42,4 & 71,4 & 38,2 & 32,9 & 33,7 \\
\hline & 2079 & 21,8 & 19,4 & 24,4 & 29,5 & 28,8 & 52,3 & 38,1 & 26,9 & 23,6 \\
\hline
\end{tabular}

$1-(\% \mathrm{CC}) ; 2-\left(\mathrm{kgN}^{-1} \mathrm{ha}^{-1} \cdot \mathrm{ano}^{-1}\right)$.

\subsubsection{Eficiência de uso do nitrogênio (EUN)}

A concentração de nitrogênio total nas plantas, a quantidade de nitrogênio absorvido, de nitrogênio aparentemente recuperado e do balanço de nitrogênio aplicado, para as diferentes lâminas de irrigação e períodos de coleta dentro das diferentes doses de nitrogênio em capim Tanzânia são mostrados nas Tabelas de 27 a 29.

A eficiência de uso do fertilizante nitrogendo e fisiologia de aproveitamento do nitrogênio absorvido, estudado nas diferentes lâminas de irrigação e doses de nitrogênio em capim Tanzânia ( média de 9 cortes), e períodos de coleta dentro das diferentes doses de nitrogênio são mostrados nas Tabelas de 30 a 31 .

Considerando a tendência de comportamento de produção de massa seca durante o ciclo de desenvolvimento 2000/2001, na Tabela 29 observa-se que a média das 
concentrações de nitrogênio total nas plantas ficaram acima do valor de $1,1 \% \mathrm{~N}$, considerado como o valor crítico para planta forrageiras, segundo Humphreys (1991); segundo o autor, valores menores a este proporcionariam "déficit" de energia no rúmen durante a digestão, no qual o metabolismo dos microrganismos do rúmen ficariam com o seu trabalho limitado em função da baixa quantidade de proteína na forragem consumida.

Existe tendência de aumento nos valores de concentração de nitrogênio total na planta durante os períodos mais frios, o que seria explicado pelo menor crescimento das plantas nestes momentos, o qual acabaria por favorecer maior concentração deste nutriente na planta.

A ocorrência da estacionalidade de produção devido a fatores climáticos, fez com que durante o inverno, com o menor desenvolvimento do capim-Tanzânia, a quantidade de nitrogênio absorvido caísse para valores próximos a $9 \mathrm{~kg}$, para cada $100 \mathrm{Kg}$ de massa seca total produzida (Tabela 27).

Tabela 27. Concentração de nitrogênio nas plantas e nitrogênio absorvido, estudado em diferentes períodos de corte em capim-Tanzânia, em Piracicaba, SP.

\begin{tabular}{cccc}
\hline Coleta & $\begin{array}{c}\text { Produção } \\
\left(\mathrm{kgMS} . c o l e t^{-1}\right)\end{array}$ & $\begin{array}{c}{[\mathrm{N}]^{1}} \\
(\%)\end{array}$ & $\begin{array}{c}\text { Nabsor }^{2} \\
\left(\mathrm{kgN}^{1} 100 \mathrm{~kg} \mathrm{MS}^{-1}\right)\end{array}$ \\
\hline 1 & 3649.24 & 1.66 & 60,75 \\
2 & 2163.86 & 1.75 & 37,81 \\
3 & 1629.66 & 1.67 & 27,27 \\
4 & 1673.38 & 1.09 & 18,28 \\
5 & 582.78 & 2.06 & 12,02 \\
6 & 463.68 & 1.98 & 9,16 \\
7 & 688.13 & 2.32 & 15,95 \\
8 & 783.95 & 2.28 & 17,85 \\
9 & 1759.53 & 1.68 & 29,55 \\
\hline
\end{tabular}

1 - Concentração de Nitrogênio na planta (\%); 2 - N absorvido .

Como tendência, quando considerado somente o efeito do uso diferentes lâminas de irrigação, observa-se que para os diferentes parâmetros determinados (Tabela 28 e 30), estes tenderam a apresentar semelhanças quando comparados entre si. 
O uso do nitrogênio permitiu aumento na produção de massa seca total, e com isto um aumento nos valores de concentração de nitrogênio total e nitrogênio absorvido em plantas de capim Tanzânia (Tabelas 28 e 29).

$\mathrm{O}$ efeito positivo do uso de nitrogênio no aumento das concentrações de nitrogênio em experimentos com diferentes gramíneas, também foram observados em trabalhos de Vicente-Chandler et al. (1962), Chadhokar (1978), Power (1980b), Power (1985), Martello (1999) e Cunha et al. (2001). Com a divisão dos valores de proteína bruta determinados em alguns destes trabalhos por 6,25, pode-se determinar as concentrações de nitrogênio e assim a quantidade absorvidas de nitrogênio pela planta, em trabalhos de pesquisa.

Vicente-Chandler et al. (1962) trabalhando com Panicum maximum. e diferentes doses de nitrogênio $\left(0,200,400,800\right.$ e $1600 \mathrm{~kg} \mathrm{~N}^{-h^{-1}}$.ano $\left.^{-1}\right)$ cortado a cada 60dias, mostraram efeito positivo nas variações de concentração e absorção de nitrogênio com o aumento das doses de nitrogênio, sendo que a variação de dose entre 400 e 800 Kg N.ha ${ }^{-}$ ${ }^{1}$.ano ${ }^{-1}$ proporcionou o maior aumento nos valores de concentração (26\%), que diminuiu com o uso da maior dose de nitrogênio (21\%).

Chadhokar (1978) trabalhando com o capim-fino (Brachiaria mutica (Forsk) Stapf), e estudando a sua resposta ao nitrogênio aplicado nas dosagens de 0, 200, 400, 600 e $800 \mathrm{~kg} \mathrm{~N} \cdot \mathrm{ha}^{-1}$.ano ${ }^{-1}$ em diferentes períodos de cortes (6 e 12 semanas) durante 3 anos, também encontrou aumento substanciais nos valores de concentração de nitrogênio nas plantas com o aumento das doses de nitrogênio usada, sendo mais significativa quando a dose de nitrogênio variou entre as doses de 200 a $400 \mathrm{~kg} \mathrm{~N} \cdot \mathrm{ha}^{-1}$.ano ${ }^{-1}$.

O incremento na concentração de nitrogênio nas plantas foi de $28 \%$ quando o uso de doses de nitrogênio variaram entre $31\left(256 \mathrm{~kg} \mathrm{~N} \cdot \mathrm{ha}^{-1}\right.$.ano $\left.{ }^{-1}\right)$ e $84 \mathrm{~kg} \mathrm{~N} \cdot \mathrm{ha}^{-1}$.período ${ }^{-1}$ (756 kg N.ha ${ }^{-1} \cdot \mathrm{ano}^{-1}$ ) (Tabela 28), que proporcionaram aumentos equivalentes nas quantidades de nitrogênio absorvido pelas plantas de capim-Tanzânia. 
Tabela 28. Concentração de nitrogênio nas plantas, nitrogênio absorvido, nitrogênio aparentemente recuperado e balanço de nitrogênio aplicado, estudado em diferentes lâminas de irrigação e doses de nitrogênio em capim-Tanzânia, média de 9 cortes.

\begin{tabular}{|c|c|c|c|c|c|c|}
\hline $\begin{array}{l}\text { Lâmina } \\
(\% \mathrm{CC})\end{array}$ & $\begin{array}{c}\mathrm{N} \\
\left(\mathrm{kgN} \cdot \mathrm{ha}^{-1} \cdot \operatorname{coleta}^{-1}\right)\end{array}$ & $\begin{array}{l}\text { Produção MS } \\
\left(\text { kgMS.coleta }^{-1}\right)\end{array}$ & $\begin{array}{c}{[\mathrm{N}]^{1}} \\
(\%)\end{array}$ & $\begin{array}{c}\mathrm{Nabs}^{2} \\
\left(\mathrm{kgN}^{2} 100 \mathrm{~kg} \mathrm{MS}^{-1}\right)\end{array}$ & $\underset{(\%)}{\operatorname{NapRec}^{3}}$ & $\begin{array}{c}\text { Nabs-Napl. } \\
\left({ }^{4 g N} \cdot h^{-1}\right)\end{array}$ \\
\hline \multirow{5}{*}{0} & 0 & $1.330,1$ & 1,35 & 17,99 & - & $-18,0$ \\
\hline & 11 & $1.430,2$ & 1,29 & 18,49 & 4,54 & $-7,5$ \\
\hline & 31 & $1.703,0$ & 1,60 & 27,26 & 30,32 & 3,3 \\
\hline & 84 & $2.155,7$ & 2,15 & 46,45 & 33,88 & 37,6 \\
\hline & 231 & $2.703,5$ & 2,63 & 71,03 & 22,96 & 160,0 \\
\hline \multirow{5}{*}{30} & 0 & $1.549,0$ & 1,40 & 21,61 & - & $-21,6$ \\
\hline & 11 & $1.132,4$ & 1,41 & 16,93 & - & $-6,0$ \\
\hline & 31 & $1.208,3$ & 1,49 & 17,04 & 0,36 & 13,6 \\
\hline & 84 & $2.492,3$ & 2,16 & 53,76 & 43,84 & 30,2 \\
\hline & 231 & $2.364,2$ & 2,75 & 65,00 & 20,80 & 166,0 \\
\hline \multirow{5}{*}{70} & 0 & 862,9 & 1,19 & 10,27 & - & $-10,3$ \\
\hline & 11 & $1.546,4$ & 1,46 & 22,62 & 112,34 & $-11,6$ \\
\hline & 31 & $1.632,6$ & 1,77 & 28,86 & 60,86 & 1,7 \\
\hline & 84 & $2.188,8$ & 2,20 & 48,22 & 45,19 & 35,8 \\
\hline & 231 & $2.937,4$ & 2,57 & 75,42 & 28,21 & 155,6 \\
\hline \multirow{5}{*}{100} & 0 & 761,3 & 1,27 & 9,68 & - & $-9,7$ \\
\hline & 11 & $1.140,3$ & 1,44 & 16,37 & 60,82 & $-5,4$ \\
\hline & 31 & $1.752,0$ & 1,52 & 26,66 & 55,57 & 3,9 \\
\hline & 84 & $2.042,1$ & 2,23 & 45,59 & 42,75 & 38,4 \\
\hline & 231 & $2.805,2$ & 2,79 & 78,23 & 29,68 & 152,8 \\
\hline \multirow{5}{*}{150} & 0 & 810,4 & 1,40 & 11,37 & - & $-11,4$ \\
\hline & 11 & 950,3 & 1,37 & 13,06 & 15,38 & $-2,1$ \\
\hline & 31 & $1.374,9$ & 1,50 & 20,64 & 30,31 & 9,9 \\
\hline & 84 & $2.083,0$ & 2,16 & 45,05 & 40,09 & 39,0 \\
\hline & 231 & $2.655,6$ & 2,69 & 71,46 & 26,01 & 159,5 \\
\hline
\end{tabular}

1 - Concentração de Nitrogênio na planta (\%); 2 - $\mathrm{N}$ absorvido; $3-\mathrm{N}$ aparentemente recuperado $(\mathrm{kg} \mathrm{N}$ absorvido.kg $\mathrm{N}$ aplicado $^{-1}$ ); 4- Variação entre $\mathrm{N}$ absorvido e $\mathrm{N}$ aplicado através de adubação,

Quando estudando o efeito do uso de nitrogênio dentro dos diferentes períodos de coletas, observa-se variação de valores de concentração nas plantas influenciadas por momentos climáticos típicos dentro de cada estação estudada (Tabela 29),

As concentrações nas plantas, dentro de condições favoráveis de crescimento (temperatura e fotoperíodo), mostraram semelhanças entre si quando se fizeram uso de doses de nitrogênio até $31 \mathrm{~kg} \mathrm{~N} \cdot \mathrm{ha}^{-1}$.período ${ }^{-1}\left(256 \mathrm{~kg} \mathrm{~N} \cdot \mathrm{ha}^{-1}\right.$.ano $\left.{ }^{-1}\right)$ dentro dos períodos de coleta de 1 a 3, A menores variações encontradas de concentração de nitrogênio nas plantas $(8 \% \mathrm{~N})$ quando comparadas as doses de nitrogênio de $31\left(256 \mathrm{~kg} \mathrm{~N} \cdot \mathrm{ha}^{-1}\right.$.ano $\left.{ }^{-1}\right)$ 
para $84 \mathrm{~kg} \mathrm{~N} \cdot \mathrm{ha}^{-1}$,período ${ }^{-1}\left(756 \mathrm{~kg} \mathrm{~N} \cdot \mathrm{ha}^{-1} \cdot\right.$ ano $\left.^{-1}\right)$ durante o período experimental, poderiam ser explicados por possível contribuição positiva da mineralização da matéria orgânica do solo em fornecer $\mathrm{N}$ mineral para as menores doses de nitrogênio usadas.

Jarvis et al. (1995) citando Hatch et al., comentam que quando amostras intactas de solos (7 dias) foram incubadas, coletadas de pastagens em solo argiloso durante um ano, estas apresentaram taxas de mineralização líquidas anuais de 63, 146, 141 e 279 $\mathrm{kg} \mathrm{N}$.ha ${ }^{-1}$, quando os solos eram caracterizados como não drenados ou drenados, quando não adubados ou adubados com $400 \mathrm{~kg} \mathrm{~N} \cdot \mathrm{ha}^{-1}$, respectivamente.

A possível participação da mineralização dentro das sub-parcelas que receberam as menores dosagens de nitrogênio, seria observado quando foi calculado o balanço das diferenças entre as quantidades de nitrogênio ofertado à planta pela adubação nitrogenada e a quantidade absorvida pela planta, durante todo período de estudo (Tabelas 28 e 29), Valores negativos de balanço de nitrogênio foram encontrados geralmente nas doses de nitrogênio variando entre 0 e $11 \mathrm{~kg} \mathrm{~N}^{-h^{-1}}$.período ${ }^{-1} \quad(100 \mathrm{~kg}$ N.ha ${ }^{-1}$.ano ${ }^{-1}$ ), e de maneira mais significativamente nas primeiras coletas ( 1 a 3 ).

Possivelmente a mineralização da matéria orgânica de um material mais rico em nitrogênio (adubações anteriores de manutenção e uso anterior da área) e ocorrida em condições climáticas mais favoráveis, pode ter permitido aumento nos valores de concentração e nitrogênio absorvidos pelas plantas nas menores doses de nitrogênio usados inicialmente (coletas 1 a 3) (Tabela 29).

Com a continuidade desta mineralização e o inicio das condições climáticas favoráveis novamente no final do experimento (coleta 9), os valores de concentração de $\mathrm{N}$ na massa seca e quantidade de $\mathrm{N}$ absorvida mostraram-se menores, possivelmente devido ao empobrecimento em nitrogênio presente na matéria orgânica final, Esta matéria orgânica mesmo apresentando-se em quantidade equivalente à presente no início do experimento (Tabelas de 1 a 4), devido possivelmente a este empobrecimento, poderiam vir a explicar a degradação ocorrida nas pastagens que usaram as menores doses de nitrogênio. 
Tabela 29. Concentração de nitrogênio nas plantas, nitrogênio absorvido, nitrogênio aparentemente recuperado e balanço de nitrogênio aplicado, estudado em diferentes coletas e doses de nitrogênio em capim-Tanzânia, média de 9 cortes.

\begin{tabular}{|c|c|c|c|c|c|c|}
\hline Coleta & $\begin{array}{c}\mathrm{N} \\
\left(\mathrm{kgN} \cdot \mathrm{ha}^{-1} \cdot \mathrm{col}^{-1}\right)\end{array}$ & 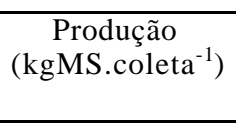 & $\begin{array}{l}{[\mathrm{N}]^{1}} \\
(\%)\end{array}$ & $\begin{array}{c}\mathrm{Nabs}^{2} \\
\left(\mathrm{kgN} .100 \mathrm{~kg} \mathrm{MS}^{-1}\right)\end{array}$ & $\begin{array}{c}\text { NapRec }^{3} \\
\text { (kgN absor.kg N } \\
\left.\text { aplic }^{-1}\right)\end{array}$ & $\begin{array}{c}\text { Nabs-Napl, }^{4} \\
\left(\mathrm{kgN} \cdot \mathrm{ha}^{-1}\right)\end{array}$ \\
\hline \multirow{5}{*}{1} & 0 & $3.755,78$ & 1,57 & 58,86 & - & $-58,9$ \\
\hline & 11 & $3.546,29$ & 1,46 & 51,82 & $-64,01$ & $-40,8$ \\
\hline & 31 & $3.439,08$ & 1,54 & 53,01 & $-19,14$ & $-22,4$ \\
\hline & 84 & $3.938,75$ & 1,73 & 67,97 & 10,84 & 16,0 \\
\hline & 231 & $4.724,50$ & 2,03 & 95,86 & 16,02 & 135,1 \\
\hline \multirow{5}{*}{2} & 0 & $1.271,22$ & 1,55 & 19,69 & - & $-19,7$ \\
\hline & 11 & $1.747,13$ & 1,48 & 25,79 & 55,46 & $-14,8$ \\
\hline & 31 & $2.199,31$ & 1,60 & 35,26 & 50,94 & $-4,7$ \\
\hline & 84 & $3.301,80$ & 1,76 & 58,02 & 45,63 & 26,0 \\
\hline & 231 & $5.080,37$ & 2,35 & 119,47 & 43,20 & 111,5 \\
\hline \multirow{5}{*}{3} & 0 & $1.265,45$ & 1,52 & 19,22 & - & $-19,2$ \\
\hline & 11 & $1.571,33$ & 1,49 & 23,37 & 33,38 & $-12,4$ \\
\hline & 31 & $1.800,78$ & 1,52 & 27,42 & 25,29 & 3,1 \\
\hline & 84 & $2.091,50$ & 1,65 & 34,58 & 17,72 & 49,4 \\
\hline & 231 & $2.530,51$ & 2,19 & 55,38 & 15,45 & 175,6 \\
\hline \multirow{5}{*}{4} & 0 & $1.106,33$ & 0,87 & 9,67 & - & $-9,7$ \\
\hline & 11 & $1.519,73$ & 0,92 & 13,95 & 38,93 & $-3,0$ \\
\hline & 31 & $1.588,83$ & 1,03 & 16,30 & 21,70 & 14,3 \\
\hline & 84 & $2.489,57$ & 1,00 & 25,00 & 18,25 & 59,0 \\
\hline & 231 & $2.745,20$ & 1,64 & 45,08 & 15,33 & 185,9 \\
\hline \multirow{5}{*}{5} & 0 & $4.72,66$ & 1,23 & 5,82 & - & $-5,8$ \\
\hline & 11 & $4.81,00$ & 1,53 & 7,38 & 14,14 & 3,6 \\
\hline & 31 & 594,76 & 1,78 & 10,56 & 15,51 & 20,0 \\
\hline & 84 & 823,64 & 2,77 & 22,81 & 20,23 & 61,2 \\
\hline & 231 & 903,89 & 3,00 & 27,12 & 9,22 & 203,9 \\
\hline \multirow{5}{*}{6} & 0 & 332,39 & 1,14 & 3,78 & - & $-3,8$ \\
\hline & 11 & 342,60 & 1,41 & 4,84 & 9,65 & 6,2 \\
\hline & 31 & 503,60 & 1,57 & 7,92 & 13,53 & 22,6 \\
\hline & 84 & 736,75 & 2,87 & 21,12 & 20,63 & 62,9 \\
\hline & 231 & 827,35 & 2,89 & 23,88 & 8,70 & 207,1 \\
\hline \multirow{5}{*}{7} & 0 & 286,92 & 1,50 & 4,31 & - & $-4,3$ \\
\hline & 11 & 465,90 & 1,41 & 6,59 & 20,71 & 4,4 \\
\hline & 31 & 810,38 & 1,87 & 15,15 & 35,49 & 15,4 \\
\hline & 84 & $1.242,84$ & 3,14 & 38,98 & 41,27 & 45,0 \\
\hline & 231 & $1.503,87$ & 3,67 & 55,19 & 22,03 & 175,8 \\
\hline \multirow{5}{*}{8} & 0 & 285,70 & 1,39 & 3,98 & - & $-4,0$ \\
\hline & 11 & 422,48 & 1,71 & 7,22 & 29,44 & 3,8 \\
\hline & 31 & 913,53 & 1,93 & 17,61 & 44,62 & 12,9 \\
\hline & 84 & $1.945,29$ & 2,88 & 56,02 & 61,96 & 28,0 \\
\hline & 231 & $2.227,54$ & 3,48 & 77,47 & 31,82 & 153,5 \\
\hline \multirow{5}{*}{9} & 0 & 788,23 & 1,13 & 8,91 & - & $-8,9$ \\
\hline & 11 & $1.199,40$ & 1,15 & 13,75 & 43,98 & $-2,7$ \\
\hline & 31 & $1.820,55$ & 1,36 & 24,69 & 51,64 & 5,9 \\
\hline & 84 & $3.161,26$ & 1,85 & 58,36 & 58,87 & 25,6 \\
\hline & 231 & $3.695,33$ & 2,92 & 107,83 & 42,82 & 123,2 \\
\hline
\end{tabular}

1 - Concentração de Nitrogênio na planta (\%); 2 - N absorvido; 3 - N aparentemente recuperado (kg Nabsor.kg N aplicado $^{-1}$ ); 4- Variação entre $\mathrm{N}$ absorvido e $\mathrm{N}$ aplicado através de adubação, 
Quando do uso de doses de nitrogênio variando entre 84 e 231 kg N.ha-1. período1, observa-se aumento na concentração deste nutriente nos tecidos das plantas durante os períodos de coleta 5 a 8 (períodos mais frios, com déficit hídrico regional e menor produção de massa seca), com posterior diminuição após o aparecimento de condições climáticas favoráveis às plantas.

Power (1980b), comenta que a concentração de $\mathrm{N}$ pode apresentar um grau de associação baixo com a dose de fertilizante usado, no qual em função de fatores climáticos favoráveis (principalmente precipitação), tem-se a diminuição nos teores de $\mathrm{N}$ na planta em função do aumento de biomassa produzida, sendo isto chamado de efeito de diluição do nitrogênio no tecido. Gillet (1984) citado por Cunha et al, (2001), comenta que a diminuição do $\mathrm{N}$ provoca em muitos casos aumento na absorção, porém esta nunca é suficiente para compensar esta diluição, sendo que para igual fertilização, quanto mais crescimento ou produção da pastagem, menos rica em proteína bruta (PB) (ou concentração de nitrogênio no tecido) esta será, Geralmente nesta variação inversa entre teores de PB e a produtividade de MS, são os teores de PB os que variam menos, já que os aumentos na absorção pela planta compensam em parte os efeitos da diluição.

Werner \& Haag (1972) num estudo sobre a nutrição de algumas gramíneas forrageiras tropicais em solução nutritiva, constataram que o capim colonião com teor de 0,67 \% de $\mathrm{N}$ (considerado-se a planta inteira) tinha seu crescimento limitado e que apresentava crescimento normal quando este teor era de $1,06 \% \mathrm{~N}$. Constataram ainda, que a concentração de nitrogênio era maior nas folhas novas do que nas folhas velhas, No capim-Tanzânia, a diminuição de teores de nitrogênio nos tecidos abaixo daquele ideal para crescimento normal, só ocorreu quando a planta encontrou-se dentro do único momento em que um efeito de "déficit" hídrico (coleta 4) proporcionaram diminuição na produção deste capim. Com o efeito do florescimento ocorrido também nesta mesma coleta, efeito na diminuição dos teores de $\mathrm{N}$ nas folhas podem ter sido causados por uma redistribuição de parte do $\mathrm{N}$ das folhas para a inflorescência em formação.

Considerando novamente o balanço apresentado nas Tabelas 28 e 29, observase que o uso de doses de nitrogênio acima de $31 \mathrm{~kg} \mathrm{~N} \cdot \mathrm{ha}^{-1}$.periodo ${ }^{-1}$ permitiram perdas na proporção de até 50 \% daquele nitrogênio aplicados após o corte do capim. 
Com relação a porcentagem de nitrogênio recuperado (Tabela 28), pode-se observar como tendência, de que uso de doses de nitrogênio até $81 \mathrm{~kg} \mathrm{~N} \cdot \mathrm{ha}^{-1}$.período ${ }^{-1}$ $\left(756 \mathrm{~kg} \mathrm{~N} \cdot \mathrm{ha}^{-1} \cdot \mathrm{ano}^{-1}\right)$ permitiram recuperação superior a $40 \%$ do nitrogênio ofertado à planta, sendo esta recuperação menor quando considerado o não uso de irrigação (33\%). Este comportamento também foi encontrado nos períodos mais secos presentes na Tabela 29.

Vicente-Chandler et al. (1961) e Vicente-Chandler et al. (1962) trabalhando com doses de nitrogênio até $1793 \mathrm{~kg} \cdot \mathrm{ha}^{-1} \cdot \mathrm{ano}^{-1}$ com Digitaria decumbens. e Panicum maximum, , e Vicente-Chandler et al. (1972) e Caro-Costas et al. (1972) usando doses de nitrogênio até $896 \mathrm{~kg} \mathrm{~N} \cdot \mathrm{ha}^{-1} . \mathrm{ano}^{-1}$ em Brachiaria ruziziensis e Cynodon dactylon , mostraram que doses de nitrogênio superiores a $600 \mathrm{~kg} \mathrm{~N} \cdot \mathrm{ha}^{-1} \cdot \mathrm{ano}^{-1}$ (Brachiaria ruziziensis e Cynodon dactylon) e $800 \mathrm{~kg} \mathrm{~N} \cdot \mathrm{ha}^{-1}$.ano ${ }^{-1}$ (Digitaria decumbens e Panicum maximum), tem-se diminuição na quantidade nutriente recuperado pela planta.

Chadhokar (1978), trabalhando com Brachiaria mutica (Forssk.) Stapf não identificou diminuição na quantidade de nitrogênio recuperado quando utilizou-se até $800 \mathrm{~kg} \mathrm{~N} \cdot \mathrm{ha}^{-1} \cdot$ ano $^{-1}$, mas sim diminuição dos incrementos quando as doses de nitrogênio foram superiores a $400 \mathrm{kgN} \cdot \mathrm{ha}^{-1} \cdot \mathrm{ano}^{-1}$.

As menores taxas de nitrogênio recuperado apresentadas nas Tabela 28 e 29, poderiam ser a variação da disponibilidade hídrica sofrido individualmente por cada tratamento de lâmina de irrigação recebida em determinados momentos, onde apresentariam quantidades de água disponível diferenciadas entre si, e assim efeitos diferenciados quanto à taxa de nitrogênio recuperado. $\mathrm{O}$ suprimento de água presente no solo tem papel importante na recuperação do nitrogênio pelas culturas em geral. Benbi (1990), trabalhando com aveia de inverno encontrou para quatro doses de nitrogênio (25,

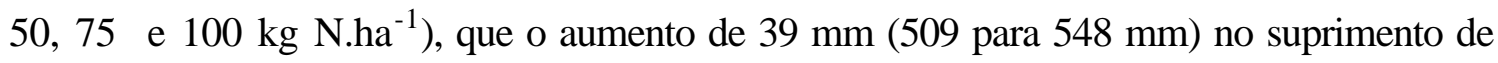
água no solo aumentou a taxa de recuperação de nitrogênio para todas as doses usadas, não ocorrendo aumento quando o suprimento passou para $51 \mathrm{~mm}$ (548 para $599 \mathrm{~mm}$ ), Possivelmente, maior quantidade de água disponível proporcionou diminuição deste nitrogênio recuperado, em função da maior probabilidade de lixiviação de nutrientes em profundidade no solo. 
Power (1980b) comenta que o nitrogênio não recuperado pelas plantas, poderia ser imobilizado pelas raízes ou permanecer tal como nitrogênio inorgânico no solo, e então ser imobilizado em outras formas de matéria orgânica no solo (incluindo tecido microbiano), ou ser perdido do sistema solo-planta na forma gasosa. No presente experimento, não houve evidência em dados coletados de monitoramento de nitrato no solo abaixo da zona de atividade radicular (experimento paralelo realizado), nem evidência de escorrimento superficial, e talvez a presumível fixação do amônio tenha sido pequena.

Possivelmente, a variabilidade encontrada nos parâmetros estudados e a falta de lógica em determinados períodos de coleta, podem estar relacionado ao material enviado para análise bromatológica, o mesmo empregado na determinação da massa seca total, composto de material foliar e também de hastes, as quais apresentam maior participação com o uso de maiores doses de nitrogênio. Monteiro (1995) citando Santos et al., que trabalhando com Panicum maximum cv, Vencedor e níveis de nitrogênio, menciona que o teor de nitrogênio aumenta linearmente em diferentes partes da planta, mediante o uso de nitrogênio, sendo encontrado as maiores concentrações em lâminas de folhas novas e as menores em colmos e bainhas.

Com o aumento da dose de fertilizante nitrogenado, a eficiência de uso do nitrogênio (EUN) pelo capim-Tanzânia apresenta tendência de redução em seus valores (Tabela 30 e 31). Os valores encontrados de EUN nas Tabelas 30 e 31 mostraram-se inferiores àqueles encontrados por Lugão (2001) em Panicum maximum (acesso BRA006998) e próximas àqueles encontrados por Chadhokar (1978) em Brachiaria mutica .

No uso de doses de nitrogênio até o máximo de $31 \mathrm{~kg} \mathrm{~N} \cdot \mathrm{ha}^{-1}$.período ${ }^{-1}$, verificaram tendência de maiores EUN do que quando usados doses acima de $81 \mathrm{~kg}$ $\mathrm{N} / \mathrm{ha}^{-1}$.período $^{-1}$ (Tabela 30). Power (1985), trabalhando com algumas gramíneas nativas (cool-season grasses) e três doses de nitrogênio $\left(0,45\right.$ e $225 \mathrm{~kg} \mathrm{~N} \mathrm{ha}^{-1}$.ano ${ }^{-1}$ ) encontrou melhor uso do nitrogênio aplicado nas menores dosagens (45 kgN.ha $\left.{ }^{-1} \cdot \mathrm{ano}^{-1}\right)$ do que quando usando doses maiores. 
Tabela 30. Nitrogênio absorvido, eficiência de uso de fertilizante e eficiência fisiológica de nitrogênio absorvido, estudado nas diferentes lâminas de irrigação e doses de nitrogênio em capim-Tanzânia, média de 9 cortes.

\begin{tabular}{|c|c|c|c|c|}
\hline $\begin{array}{l}\text { Lâmina } \\
\text { (\%CC) }\end{array}$ & $\begin{array}{c}\mathrm{N} \\
\left(\mathrm{kgN}^{-1} \mathrm{ha}^{-1} \cdot \mathrm{Col}^{-1}\right)\end{array}$ & $\begin{array}{c}\text { Nabs }^{1} \\
\left(\mathrm{kgN} .100 \mathrm{~kg} \mathrm{MS}^{-1}\right)\end{array}$ & 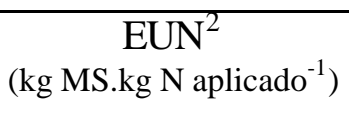 & $\begin{array}{l}\mathrm{EFNabs}^{3} \\
\left(\mathrm{~kg} \mathrm{MS.kg} \mathrm{N}^{-1}\right. \\
\left.\text { absorvido }^{-1}\right)\end{array}$ \\
\hline \multirow{5}{*}{0} & 0 & 17,99 & - & - \\
\hline & 11 & 18,49 & 9,09 & 200,23 \\
\hline & 31 & 27,26 & 12,20 & 40,24 \\
\hline & 84 & 46,45 & 9,83 & 29,01 \\
\hline & 231 & 71,03 & 5,95 & 25,89 \\
\hline \multirow{5}{*}{30} & 0 & 21,61 & - & - \\
\hline & 11 & 16,93 & - & - \\
\hline & 31 & 17,04 & 2,48 & 690,00 \\
\hline & 84 & 53,76 & 16,19 & 43,84 \\
\hline & 231 & 65,00 & 5,33 & 20,80 \\
\hline \multirow{5}{*}{70} & 0 & 10,27 & - & - \\
\hline & 11 & 22,62 & 62,13 & 55,31 \\
\hline & 31 & 28,86 & 25,19 & 41,38 \\
\hline & 84 & 48,22 & 15,78 & 34,93 \\
\hline & 231 & 75,42 & 8,98 & 31,84 \\
\hline \multirow{5}{*}{100} & 0 & 9,68 & - & - \\
\hline & 11 & 16,37 & 34,46 & 56,65 \\
\hline & 31 & 26,66 & 32,42 & 58,34 \\
\hline & 84 & 45,59 & 15,25 & 35,67 \\
\hline & 231 & 78,23 & 8,85 & 29,82 \\
\hline \multirow{5}{*}{150} & 0 & 11,37 & - & - \\
\hline & 11 & 13,06 & 12,72 & 82,74 \\
\hline & 31 & 20,64 & 18,47 & 60,94 \\
\hline & 84 & 45,05 & 15,15 & 37,79 \\
\hline & 231 & 71,46 & 7,99 & 30,71 \\
\hline
\end{tabular}

1- $\mathrm{N}$ absorvido; 2 - Eficiência de uso do nitrogênio; 3 - Eficiência fisiológica do $\mathrm{N}$ absorvido,

Com o uso em excesso de água na irrigação (lâmina de irrigação $150 \%$ CC) ou em condição de presença de momentos de "déficit" de água no solo (testemunha), observa-se na Tabela 30 tendência de menores valores de EUN quando comparado às parcelas que receberam 70 e $100 \%$ da lâmina de água necessária para elevar a capacidade de campo. Esta menor eficiência de uso do nitrogênio pode ser devido a maior perda do $\mathrm{N}$ no solo por lixiviação em condição de excesso de água, e pela diminuição da EUA que afeta diretamente a absorção de nitrogênio pela planta, e assim destas duas maneiras diretamente a produção de massa seca . 
Tabela 31. Nitrogênio absorvido, eficiência de uso de fertilizante e eficiência fisiológica de nitrogênio absorvido, estudado em cada coleta experimental e doses de nitrogênio em capim-Tanzânia.

\begin{tabular}{|c|c|c|c|c|c|}
\hline Coleta & $\begin{array}{c}\mathrm{N} \\
\left(\mathrm{kgN} \cdot \mathrm{ha}^{-1} \cdot \mathrm{col}^{-1}\right) \\
\end{array}$ & $\begin{array}{c}\text { Produção } \\
(\text { kgMS.coleta })\end{array}$ & $\begin{array}{c}\mathrm{Nabs}^{1} \\
(\mathrm{kgN} .100 \mathrm{~kg} \mathrm{MS})^{1-}\end{array}$ & $\begin{array}{c}\text { EUN }^{2} \\
\left(\mathrm{kgMS} / \mathrm{kg} \mathrm{N}_{\text {aplic }}{ }^{-1},\right)\end{array}$ & $\begin{array}{c}\text { EFNabs } \\
\left.{ }^{3} \text { kgMS/kg N } \text { absor }^{-1}\right)\end{array}$ \\
\hline \multirow{5}{*}{1} & 0 & $3.755,78$ & 58,86 & - & - \\
\hline & 11 & $3.546,29$ & 51,82 & $-19,04$ & 29,75 \\
\hline & 31 & $3.439,08$ & 53,01 & $-10,36$ & 54,14 \\
\hline & 84 & $3.938,75$ & 67,97 & 2,18 & 20,09 \\
\hline & 231 & $4.724,50$ & 95,86 & 4,19 & 26,18 \\
\hline \multirow{5}{*}{2} & 0 & $1.271,22$ & 19,69 & - & - \\
\hline & 11 & $1.747,13$ & 25,79 & 43,26 & 78,01 \\
\hline & 31 & $2.199,31$ & 35,26 & 30,37 & 59,62 \\
\hline & 84 & $3.301,80$ & 58,02 & 24,17 & 52,98 \\
\hline & 231 & $5.080,37$ & 119,47 & 16,49 & 38,17 \\
\hline \multirow{5}{*}{3} & 0 & $1.265,45$ & 19,22 & - & - \\
\hline & 11 & $1.571,33$ & 23,37 & 27,81 & 73,73 \\
\hline & 31 & $1.800,78$ & 27,42 & 17,52 & 65,25 \\
\hline & 84 & $2.091,50$ & 34,58 & 9,83 & 53,78 \\
\hline & 231 & $2.530,51$ & 55,38 & 5,48 & 34,98 \\
\hline \multirow{5}{*}{4} & 0 & $1.106,33$ & 9,67 & - & - \\
\hline & 11 & $1.519,73$ & 13,95 & 37,58 & 96,55 \\
\hline & 31 & $1.588,83$ & 16,30 & 15,79 & 72,75 \\
\hline & 84 & $2.489,57$ & 25,00 & 16,47 & 90,25 \\
\hline & 231 & $2.745,20$ & 45,08 & 7,09 & 46,29 \\
\hline \multirow{5}{*}{5} & 0 & 472,66 & 5,82 & - & - \\
\hline & 11 & 481,00 & 7,38 & 0,76 & 5,36 \\
\hline & 31 & 594,76 & 10,56 & 4,00 & 25,76 \\
\hline & 84 & 823,64 & 22,81 & 4,18 & 20,66 \\
\hline & 231 & 903,89 & 27,12 & 1,87 & 20,25 \\
\hline \multirow{5}{*}{6} & 0 & 332,39 & 3,78 & - & - \\
\hline & 11 & 342,60 & 4,84 & 0,93 & 9,62 \\
\hline & 31 & 503,60 & 7,92 & 5,60 & 41,42 \\
\hline & 84 & 736,75 & 21,12 & 4,81 & 23,33 \\
\hline & 231 & 827,35 & 23,88 & 2,14 & 24,63 \\
\hline \multirow{5}{*}{7} & 0 & 286,92 & 4,31 & - & - \\
\hline & 11 & 465,90 & 6,59 & 16,27 & 78,56 \\
\hline & 31 & 810,38 & 15,15 & 17,13 & 48,27 \\
\hline & 84 & $1.242,84$ & 38,98 & 11,38 & 27,58 \\
\hline & 231 & $1.503,87$ & 55,19 & 5,27 & 23,92 \\
\hline \multirow{5}{*}{8} & 0 & 285,70 & 3,98 & - & - \\
\hline & 11 & 422,48 & 7,22 & 12,43 & 42,23 \\
\hline & 31 & 913,53 & 17,61 & 20,54 & 46,04 \\
\hline & 84 & $1.945,29$ & 56,02 & 19,76 & 31,89 \\
\hline & 231 & $2.227,54$ & 77,47 & 8,41 & 26,42 \\
\hline \multirow{5}{*}{9} & 0 & 788,23 & 8,91 & - & - \\
\hline & 11 & $1.199,40$ & 13,75 & 37,38 & 84,99 \\
\hline & 31 & $1.820,55$ & 24,69 & 33,78 & 65,42 \\
\hline & 84 & $3.161,26$ & 58,36 & 28,25 & 47,99 \\
\hline & 231 & $3.695,33$ & 107,83 & 12,58 & 29,39 \\
\hline
\end{tabular}

1- N absorvido; 2 - Eficiência de uso do nitrogênio; 3 - Eficiência fisiológica do $\mathrm{N}$ absorvido. 
Petr et al, (1988) comentaram que a EUN pode depender do momento e método de aplicação do fertilizante, onde melhores efeitos são resultantes de aplicações feitas durante a primavera, quando ocorreria o início da fase de maior crescimento das gramíneas. Aplicações feitas durante o outono seriam ineficientes e poderiam resultar em perdas de nitrogênio na ordem de 20 a 30\% por lixiviação, sendo que estas perdas poderiam ocorrer com o início das precipitação ou de maneira constante com o uso de irrigação nas pastagens durante todo o ano.

Dobermann \& Fairhurst (2000) discutindo os diferentes índices relacionandos a eficiência de nitrogênio em cultura de arroz, comentam que esta EUN calculada nas Tabelas 30 e 31, seria representada na realidade pelo produto da eficiência de nutrientes recuperados de cada fonte de nutriente aplicado (NapRec) e pela eficiência com que a planta utilizou cada nutriente adquirido (EFNabs), onde ainda cada um destes índices poderia aumentar com a adoção de práticas racionais de manejo no solo ou cultural.

Com relação ao uso do nitrogênio absorvido pelo capim-Tanzânia, existe tendência de que o uso de doses de nitrogênio até $31 \mathrm{~kg} \mathrm{~N}^{-h^{-1}}$.período $^{-1}$ (275 kg N.ha ${ }^{1}$ ano $^{-1}$ ), permitam para cada um quilograma de nitrogênio absorvido a transformação em tecido vegetal com valores acima de $40 \mathrm{~kg}$ MS, diminuindo com o aumento da dose de nitrogênio utilizada. Maior dosagem de nitrogênio mostra menor EFNabs, sendo explicado pela associação aos menores valores de EUN (Tabelas 30 e 31).

A eficiência fisiológica do nitrogênio aplicado representa a habilidade da planta a transformar dada quantidade de fertilizante adquirido em produção econômica (massa seca) e geralmente é altamente dependente das características genotípicas da planta, as quais são também afetados pelo manejo dos nutrientes e cultura. Valores abaixo de quantidades sugeridas como ideais, os quais proporcionam boas condições de crescimento, podem ocorrer em condições de deficiência de nutrientes, toxidez, estresse hídrico ou incidência de pragas e doenças ( Dobermann \& Fairhurst, 2000 ).

Valores negativos são explicados por maiores produções de massa seca em algumas testemunhas, em função de possível variabilidade espacial de fertilidade e drenagem na área experimental. Existe tendência de que a lâmina de $70 \%$ e uma dose 
variando entre 276 e $756 \mathrm{~kg} \mathrm{~N} \cdot \mathrm{ha}^{-1}$.ano ${ }^{-1}$ favoreçam maiores valores de EUN em comparação às lâminas de 100-150\% e dose de $2079 \mathrm{kgN} \mathrm{ha}^{-1}$.ano ${ }^{-1}$ (Tabelas 30 e 31),

Fazendo-se uso dos valores resultantes do balanço entre o nitrogênio oferecido e absorvido pelas plantas (Tabela 29) e de equações de regressão entre valores deste balanço e as doses de nitrogênio utilizadas, determinou-se qual seriam a dose de nitrogênio recomendada para cada período de coleta, que permitiriam perda zero de nitrogênio para o ambiente, Considerando que este valores obtidos são meramente ilustrativos, uma vez da não existência de repetições de dados de blocos, os quais permitiriam fazer a análise de variância correta, e assim testar os $\mathrm{F}$ das equações lineares utilizando seu resíduo experimental,

As quantidades necessárias para perda zero de nitrogênio no solo em estudo, seriam de aplicações de 64, 37, 25, 14, 9, 7, 11, 14 e $21 \mathrm{~kg} \mathrm{~N} \mathrm{ha}^{-1}$.período ${ }^{-1}$ nas coleta 1 a 9, o que totalizaram a quantidade total de $202 \mathrm{~kg} \mathrm{~N} \cdot \mathrm{ha}^{-1}$, ano ${ }^{-1}$ e produção média de massa seca total de $13,362 \mathrm{~kg} \mathrm{MS} \cdot \mathrm{ha}^{-1} \cdot \mathrm{ano}^{-1}$, quando usado lâmina de irrigação suprindo $70 \%$ da capacidade de campo, 


\subsection{Análise Bromatológica:}

Os efeitos no capim Tanzânia das interações de doses de nitrogênio e lâminas de irrigação nos teores de proteína bruta (PB), digestibilidade "in vitro" da matéria orgânica (DIVMO), fibra em detergente neutro (FDN), fibra em detergente ácido (FDA) e lignina, , são observados nas Figura 32 e 33.
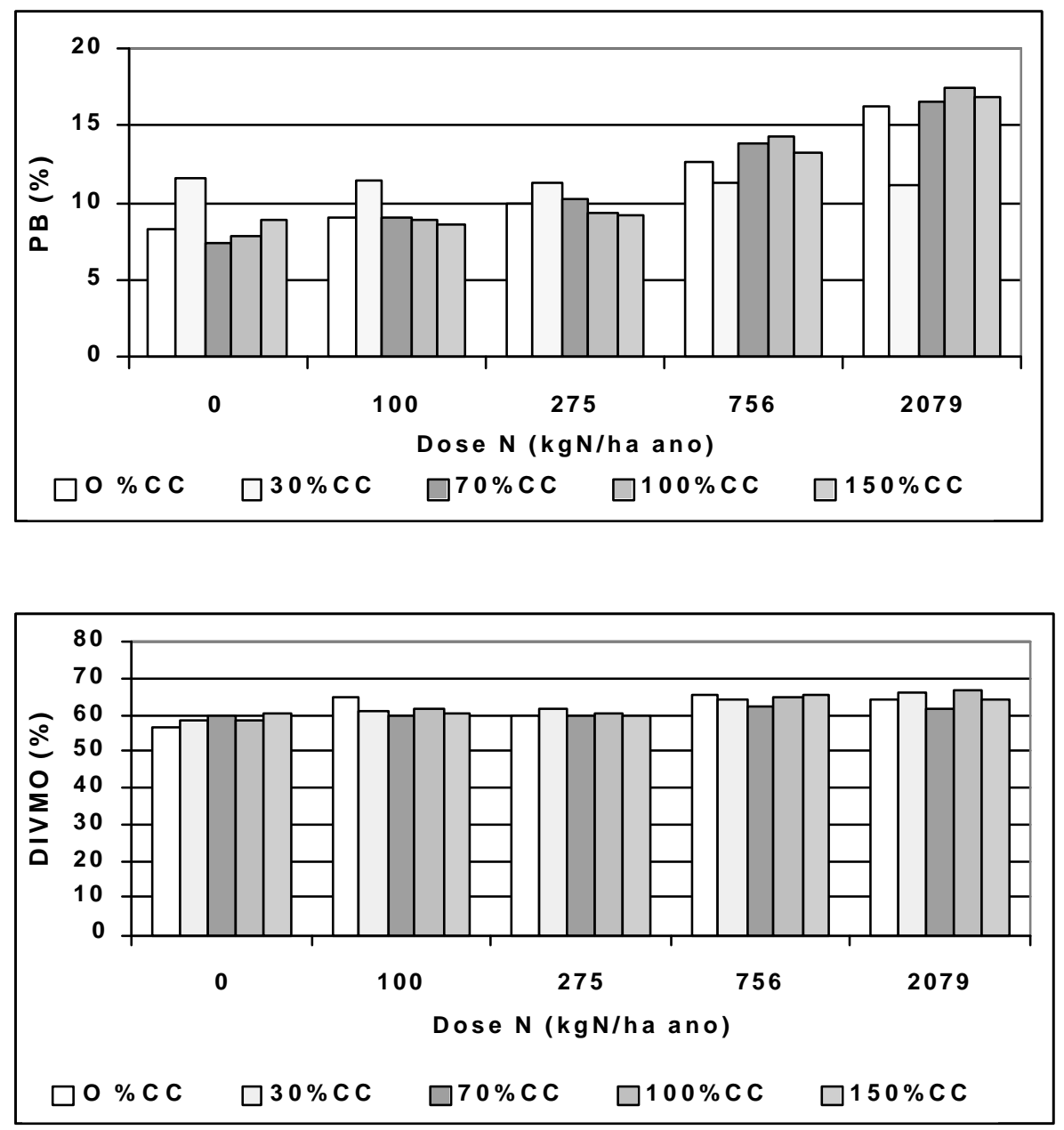

Figura 32 - Teores (\%) de PB e DIVMO, nas diferentes doses de nitrogênio dentro de cada lâmina de irrigação usada, em área de pastagem com capim Tanzânia, em Piracicaba, SP. 
O uso de nitrogênio na pastagem de capim-Tanzânia, proporcionou como tendência, aumento nos teores de proteína bruta das plantas que receberam adubação a partir de $275 \mathrm{~kg} \mathrm{~N} \cdot \mathrm{ha}^{-1}$.ano ${ }^{-1}$ ou $31 \mathrm{~kg} \mathrm{~N} \cdot \mathrm{ha}^{-1}$. período $^{-1}$ (Figura 32).

Observando a Figura 32, verifica-se que os teores de proteína bruta presentes na pastagem oferecida aos animais a cada 36 dias (simulando o manejo de pastejo rotacionado), apresentaram-se em média superiores aos valores de 6 a $7 \%$ de PB encontrados em forrageiras tropicais (Milford \& Minson citados por Euclides (1995)), considerados como nível crítico mínimo de proteína necessária para evitar limitação à fermetação ruminal. Valores menores a $6 \%$ de PB, podem permitir redução da atividade dos microrganismos do rúmen, o que consequentemente causa decréscimo nas taxas de digestão, na passagem do alimento e no consumo voluntário, limitando assim a produção máxima dos animais, segundo Euclides (1995).

Segundo Malavolta et al. (1974), as pastagens de gramíneas forrageiras quando adubadas com doses crescentes de nitrogênio, aumentam linearmente até certos limites a produção de massa seca e de proteína bruta. Sendo que de modo geral para gramíneas forrageiras tropicais, estas apresentam resposta à adubação nitrogenada até doses de $1600 \mathrm{~kg} \mathrm{~N} \cdot \mathrm{ha}^{-1}$.ano ${ }^{-1}$, embora a eficiência de utilização seja reduzida a partir de $300 \mathrm{~kg}$ N.ha ${ }^{-1} \cdot$ ano $^{-1}$.

O aumento nos teores de proteína bruta com o uso de adubação nitrogenada foi também obtido por Favoretto et al. (1988), Corrêa et al. ( 1998) e Forni et al. (2000) trabalhando com gramíneas forrageiras do gênero Panicum (Colonião, Tanzânia, Vencedor, Mombaça e Centenário), e por Menegatti et al. (1999) em gramíneas do gênero Cynodon (Coastcross, Tifton 68 e 85).

O que deve ser observado, é que mesmo com a adubação nitrogenada aumentando a produtividade das pastagens, a sua influência sobre o valor alimentício da pastagem seria função dos efeitos positivos e negativos referente ao uso do nitrogênio. Como efeito positivo ao uso, tería-se o estímulo ao crescimento de tecidos novos que apresentam maiores teores de proteína bruta e digestibilidade (maior valor da DIVMS e menores de fibra em detergente neutro (FDN) e lignina). Com o uso do manejo incorreto de pastagem, problemas como efeito negativo o aumento nos valores de índice de área 
foliar (IAF) ocasionando acréscimo na taxa de senescência foliar e acúmulo de material morto nesta pastagem, aumento de altura de caule, e assim propiciando diminuição na qualidade da planta forrageira (Euclides, 1995).

Forni et al. (2000) verificaram em Panicum maximum cvs. Tanzânia e Mombaça, recebendo quatro níveis de adubação ( 102, 145, 189 e 232 kg N.ha ${ }^{-1}$ ) e avaliados em intervalos de 35 dias durante a primavera e verão de 1997, que os teores de proteína bruta média de folhas, foram sempre superiores aos teores encontrados nos colmos sob mesmo nível de adubação.

Aparentemente, o uso do nitrogênio permitiu também maiores valores de digestibilidade 'in vitro' da matéria orgânica (DIVMO), o qual é um dos melhores previsores da qualidade relativa da folhagem (Figura 32). Os maiores valores de DIVMO possivelmente estejam relacionados à presença de massa seca de melhor qualidade, a qual apresentaria maior produção de massa foliar, perfilhos novos, hastes mais tenras, que se traduz em maior consumo voluntário de matéria seca

A quantidade de fibra encontrada no material alimentar é determinada através de dois métodos, Fibra em detergente neutro (FDN) e Fibra em detergente ácido (FDA), m qual tudo exceto celulose, lignina e hemicelulose (estruturas de fibras da planta) é removido . A FDA tem relação inversa com a razão de digestibilidade, onde os menores valores de FDA indicariam maior digestibilidade da forragem e maior quantidade de nutrientes (proteínas, energia e cálcio) absorvido pelos animais. Já FDN tem uma relação inversa com o consumo voluntário de pastagem, onde menores valores de FDN indicariam um maior intenção de pastejo pela forrageira. Para evitar problemas com os animais (acidulase ruminal, laminitis e baixo teor de gordura no leite), tem se proposto usar alimentos com valores limites mínimos de FDA de $21 \%$ e FDN de $30 \%$ em relação a matéria seca quando do uso em silagem (Haenlein, 1997). 

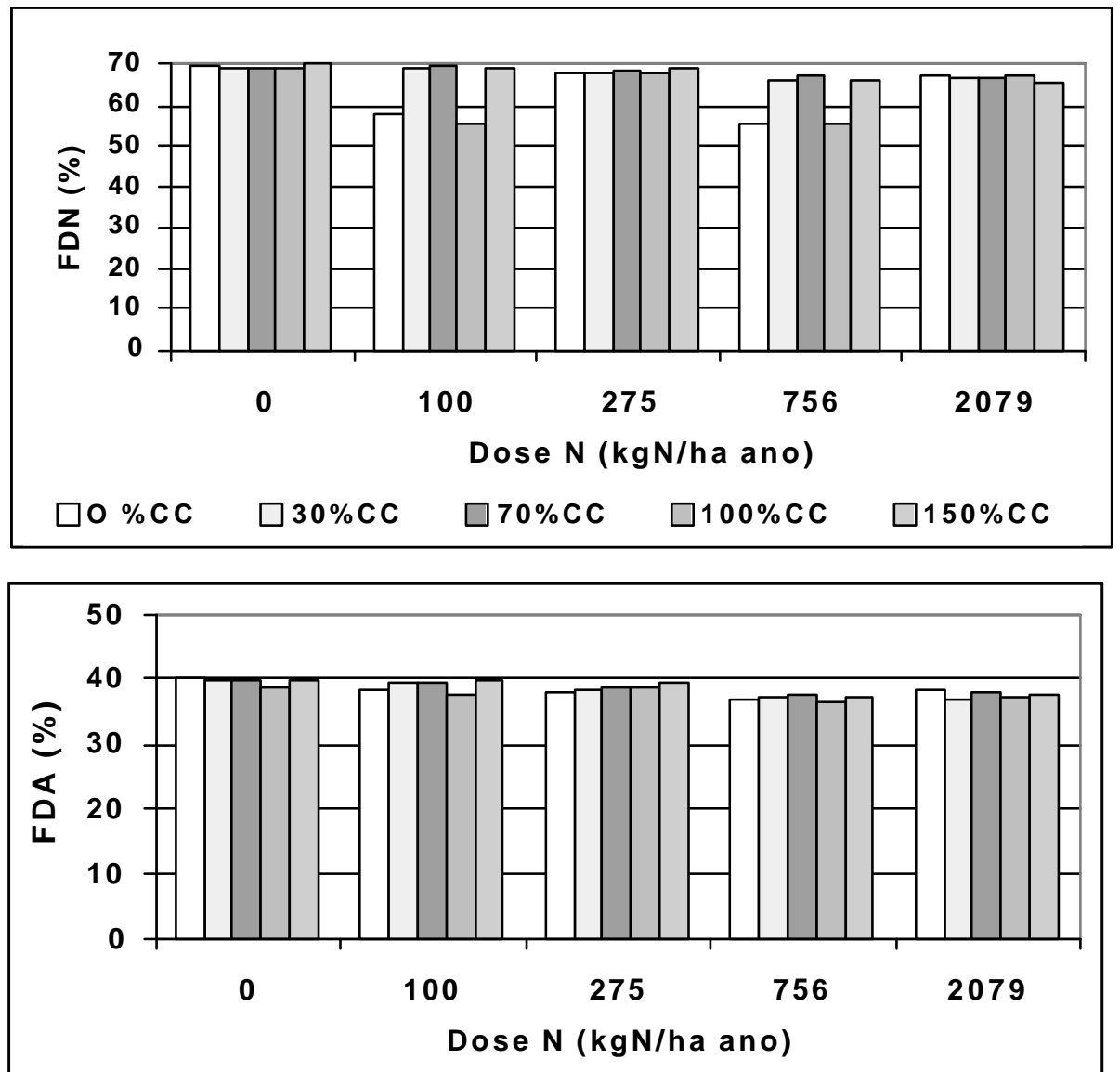

$\square 0 \%$ CC $\quad \square 30 \%$ CC $\quad \square 70 \%$ CC $\square 100 \%$ cC $\square 150 \%$ cC

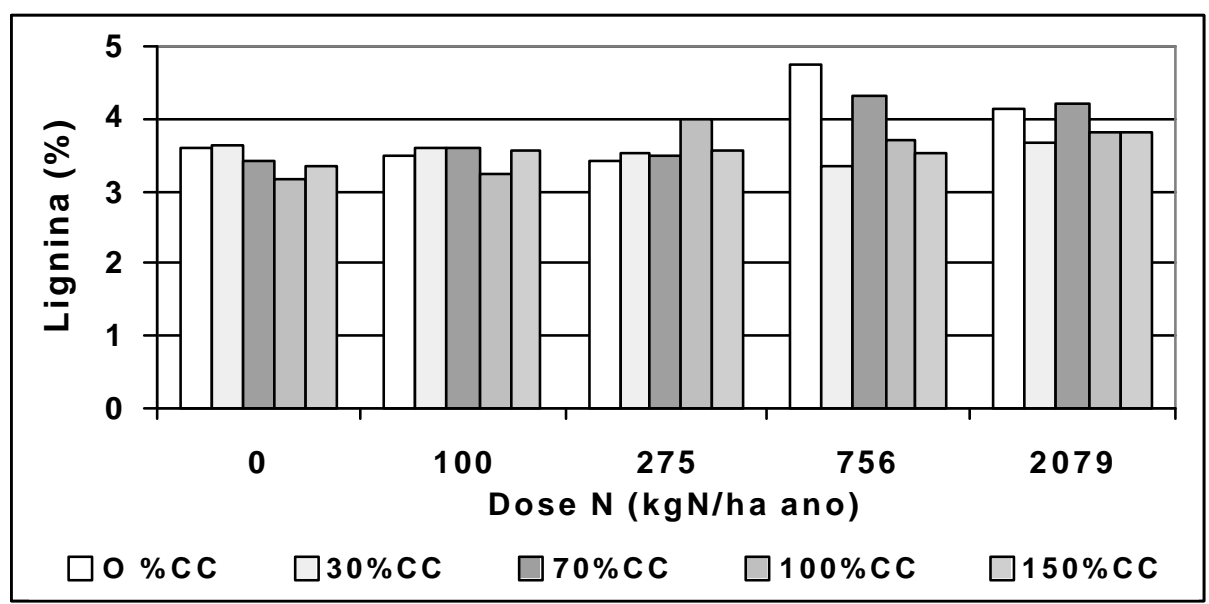

Figura 33 - Teores (\%) de FDN, FDA e Lignina nas diferentes doses de nitrogênio dentro de cada lâmina de irrigação usada , em área de pastagem com capim Tanzânia, em Piracicaba, SP. 
Euclides (1995) estudando diversos cultivares de Panicum maximum, concluiu que valores de FDN inferiores a 55\% são raros. Valores superiores a $65 \%$ são comuns em tecidos novos e teores entre 75 e $80 \%$ são encontrados em materiais de maturidade avançada.

Como tendência geral para o efeito de uso de nitrogênio dentro das diferentes lâminas de irrigação usadas, observa-se na Figura 33, que os valores de FDN apresentaram em média próximos a $66 \%$, que é comum em tecidos novos. A ocorrência da relação inversa entre DIVMS e FDA, como comentada por Paterson et al. (1994), é encontrada de maneira sutil nas Figuras 32 e 33 quando aumenta-se a quantidade de nitrogênio utilizada na pastagem .

O efeito do uso nitrogênio na qualidade da pastagem, interage de maneira direta com o estágio de crescimento do pasto. Segundo Wilson \& Minson (1980), quando pastos eram pastejado em um estágio jovem de crescimento (28 a 35 dias), maiores digestibilidades foram obtidas quando do uso de adubação nitrogenada na pastagem.

Os efeitos do uso das diferentes doses de nitrogênio, durante todo o período experimental, nso teores de proteína bruta (PB), digestibilidade "in vitro" da matéria orgânica (DIVMO), fibra de detergente neutro (FDN), fibra detergente ácido (FDA) e lignina, do capim Tanzânia, são observados nas Figura 34 e 35 respectivamente.

O uso de nitrogênio durante todos os períodos de coletas proporcionaram aumento na quantidade de PB presente na forragem (Figura 34). O nitrogênio permitiu o aumento nos teores de proteína bruta em dosagens acima de $750 \mathrm{~kg} \mathrm{~N}$.ha ${ }^{-1}$ ano $^{-1}$ (Figura 36 ), apresentando valores acima de $10 \%$ de PB, chegando a valores acima de $20 \%$ de PB nos período mais frios em função do efeito de concentração de nutrientes na planta, devido a menor produção de massa seca. O efeito positivo ao uso do nitrogênio em Panicum maximum, no aumento dos teores de PB foi encontrado também por Werner $(70 / 71)$. 

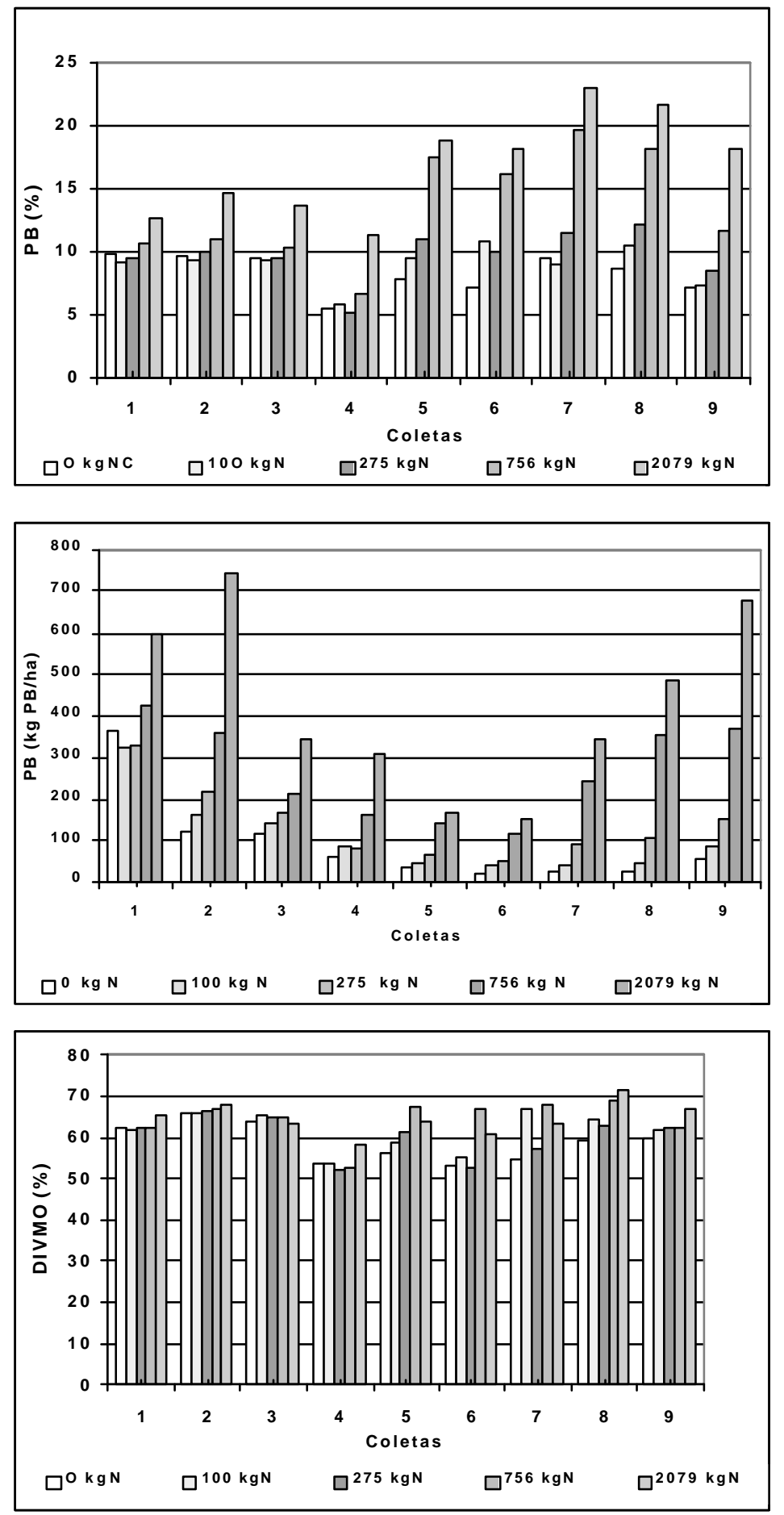

Figura 34 - Teores (\%) e quantidade de PB $\left(\mathrm{kg}\right.$ PB.ha $\left.{ }^{-1}\right)$ e DIVMO, nas diferentes adubações nitrogenadas usada dentro de cada período de coleta, em área de pastagem com capim Tanzânia, em Piracicaba, SP. 
A relação inversa existente entre os teores de $\mathrm{PB}$ e a produção de massa seca (Figura 34 e Tabela 14) foi encontrada neste experimento, como também por Martello (1999), quando utilizou de nitrogênio $\left(0,60,120\right.$ e $\left.240 \mathrm{~kg} \mathrm{~N}^{-h a^{-1}}\right)$ em capim-elefante cv. Guaçu visando maximizar a sua produção no período das secas.

A ocorrência de um efeito de diluição da PB devido a maior produção de massa seca durante o período úmido é observado, como também a ocorrência de um efeito de concentração dos teores de PB no período de inverno, com a diminuição na produção de matéria seca.

Os resultados apresentados na Figura 34, com relação à variação dos teores de PB no tempo, são concordantes com aqueles encontrados por Werner et al. (1967), quando mostram que aplicação do nitrogênio em doses variando de pequena a moderada em capim pangola, este atuava principalmente no aumento do crescimento e na produtividade da gramínea. Somente com a elevação da dose de adubação nitrogenada é que se consegue aumento acentuado nos teores de proteína na forragem. $\mathrm{O}$ uso da dose de nitrogênio de $756 \mathrm{~kg} \mathrm{~N} \cdot \mathrm{ha}^{-1} \cdot \mathrm{ano}^{-1}$ ( $84 \mathrm{~kg} \mathrm{~N} \cdot \mathrm{ha}^{-1}$.período ${ }^{-1}$ ), proporcionou aumento no teor de PB diferenciando-o das menores dosagens utilizadas.

Os conteúdos de proteína bruta produzidos por área a serem utilizados para a produção animal, seguiram a mesma variação no tempo dos teores de PB, aonde observa-se a redução da qualidade protéica da forragem oferecida durante o inverno para os animais (Figura 34) e o papel do uso do nitrogênio no aumento de PB na planta forrageira.

De modo geral, o uso de nitrogênio também proporcionou tendência de aumento nos valores de digestibilidade "ï n vitro" da matéria orgânica (DIVMO) durante o tempo de estudo (Figura 34).

Uma variação de DIVMO também pode ser observada comparando-se o comportamento total de efeito de todas dosagens de nitrogênio durante o tempo de coleta experimental, com diminuição de digestibilidade da pastagem ofertada entre a quarta e sétima coleta experimental (Figura 34). O efeito climático mostra-se como um importante fator que influi na variação da qualidade da pastagem. 
Considerando que a digestibilidade é a medida da proporção do alimento consumido que é digerido e metabolizado pelo animal, a princípio, a digestibilidade potencial de todos os componentes da planta com exceção da lignina, seriam de $100 \%$ (Whiteman (1980) citado por Reis (2000)). Assim, dependendo das espécie de planta e de seu estádio de maturidade, os constituintes da parede celular compreendem de 25 a $85 \%$ do peso seco da forragem, sendo os principais a celulose (polímero de glucose), hemicelulose e o aumento nos teores de lignina com o amadurecimento da forragem. A lignina, que é um polímero fenólico indigerível pode vir a representar de 2 a $20 \%$ do peso seco da planta, e a sua participação na pastagem apresenta relação inversa com a digestibilidade da mesma, porque ao se ligar aos polissacarídeos da parede celular acaba por restringir o acesso microbiano durante a digestão (Dove, 1996)

Portanto, a determinação destes componentes da parede celular (celulose, hemicelulose e lignina) ou do conjunto frações de fibra (FDN e FDA), presente na parede celular, e a sua associação à digestibilidade da pastagem trabalhada, é importante, uma vez que a fibra pode ser usada como índice negativo de qualidade da pastagem consumida. Correlações têm sido encontradas entre consumo e digestibilidade, consumo e FDN, degestibilidade e FDA e digestibilidade e lignina (Euclides, 1995).

A análise dos resultados relacionados à variação da qualidade de pastagem do capim-Tanzânia, deverá ser observada relacionando os comportamentos e variações de FDN, FDA, Lignina e DIVMO durante as nove coletas experimentais (Figuras 34 e 35).

Os resultados serão discutidos comparando-se duas situações distintas, uma condição no qual a pastagem não recebeu adubação nitrogenda e outra adubada com 756 $\mathrm{kg} \mathrm{N} \cdot \mathrm{Na}^{-1} . \mathrm{ano}^{-1}$, que mostram dois extremos de manejo e características próprias de desenvolvimento da pastagem. 

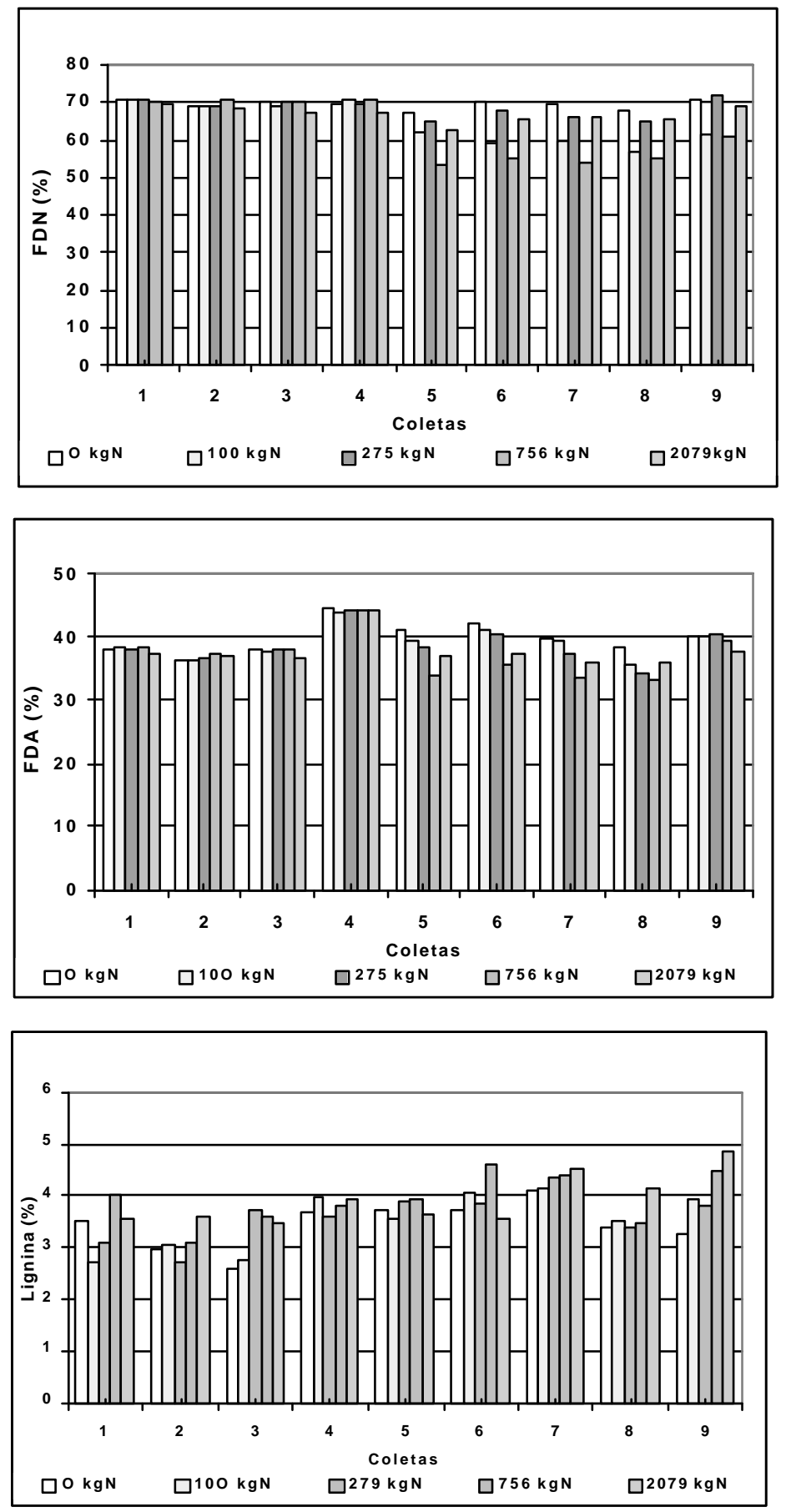

Figura 35 - Teores (\%) de FDN, FDA e Lignina nas diferentes adubações nitrogenadas usada dentro de cada período de coleta, em área de pastagem com capim Tanzânia, em Piracicaba, SP. 
Considerando o não uso de nitrogênio, observa-se nas Figuras 34 e 35 como tendência, variação nos teores de lignina e seu aumento durante o inverno. Possivelmente devido à ocorrência de deficiência por nitrogênio (menores teores de PB) causada por efeito ambiental ("déficit" hídrico regional e temperatura), que proporcionariam diminuição de altura e de qualidade de folhas (folhas menores, pontiagudas e estreitas - observação do autor) das plantas.

Herling et al. (2000) observando os efeitos de três ofertas de forragem $(3,3$, 4,1 e 4,9\%) e de período de descanso (28 e 35 dias) no valor nutritivo da matéria seca disponível em capim-Mombaça (Panicum maximum cv. Mombaça) em seis períodos de pastejo, mostraram que com o aumento da oferta de forragem de 3,3 para 4,9\%, tem-se a queda dos teores de PB e DIVMO e aumento nos valores de FDA e lignina. Relatam ainda que com a diminuição da altura de corte, que a composição bromatológica pode ser afetada, uma vez que pode-se retirar materiais mais fibrosos e com menor teor de PB.

Wendling et al. (1997), estudando também duas ofertas diárias (4 e $8 \%$ ) de pastagem de Brachiaria decumbens Stapf. na alimentação de vacas leiteiras, encontraram diminuição nos teores de PB, que seria reflexo do acúmulo de forragem velha nos piquetes sob oferta de $8 \%$ PV (Peso Vivo) estudados no período de verão.

A este aumento de lignina, explica-se a tendência de aumento nos valores de FDA, que é um índice que dá a idéia da digestibilidade do alimento e mostra com o seu aumento, diminuição na taxa de digestibilidade do capim, devido à presença de fibras não facilmente digestíveis como o aumento de lignina. Uma relação inversa entre DIVMO e FDA pode ser observada nas Figuras 34 e 35.

A não diminuição dos valores de FDN, que dão idéia da capacidade de ingestão da forragem pelo animal, mostra que no período de inverno a qualidade do material oferecido foi semelhante aos outros períodos, diferindo quando comparado aos que receberam adubação (Figura 35).

Com o uso de $756 \mathrm{~kg} \mathrm{~N} \cdot \mathrm{ha}^{-1} \cdot \mathrm{ano}^{-1}$, observa-se nas Figuras 34 e 35, comportamento geral de melhora de qualidade de forragem oferecida para pastejo durante todo período experimental, com aumento de DIVMO e PB, não variação do FDA e possível tendência de melhora na ingestão no inverno devido a diminuição dos 
valores de FDN, que sempre se mostraram próximos àqueles valores considerados ideais para o gênero Panicum (65\% - em tecidos novos ), conforme mostrado por Euclides (1995).

Correa et al. (1998) estudaram o efeito de níveis de adubação nitrogenada ( 200 e $\left.400 \mathrm{~kg} \mathrm{~N} \cdot \mathrm{ha}^{-1}\right)$ e três frequiências de corte $(25,35$ e 45 dias) na produção e qualidade de matéria seca de doze gramíneas forrageiras tropicais. Pelos resultados constatou-se que houve efeito positivo das doses de nitrogênio na produção de matéria seca, sendo variável com a espécie forrageira. Houve efeito positivo da dose de $\mathrm{N}$ no teor de $\mathrm{PB}$, decrescendo com a idade das plantas e variando com a espécie forrageira. Aumentando a idade de corte das plantas, houve decréscimo do teor de proteína bruta $(\mathrm{PB})$, porém, pouco acentuado no teor de fibra em detergente neutro (FDN), que seriam melhores avaliados pela análise de DIVMO e lignina.

Menegatti et al. (1999), avaliando a produção de massa seca e qualidade de três capins híbridos do gênero Cynodom, submetidos a quatro doses de nitrogênio $(0,100$, 200 e $400 \mathrm{~kg} \mathrm{~N} \cdot \mathrm{ha}^{-1}$ : aplicação parcelada) e três corte (35 dias) durante o verão, mostraram que o nitrogênio aumentou a produção de massa seca e PB, diminuíram os teores de FDN e não variação nos teores de DIVMS e FDA. Isto mostra o elevado potencial de uso desta gramínea quando fica evidente a melhora de sua qualidade com o uso de nitrogênio.

O aumento de lignina encontrado durante os períodos de inverno e primavera para as duas maiores adubações nitrogenadas (756 e $2076 \mathrm{~kg} \mathrm{~N}$.ha ${ }^{-1} \cdot$ ano $^{-1}$ ), não apresentaram relação com o comportamento dos índices determinados de DIVMO, FDN e FDA, como discutida anteriormente para pastagem não adubada. Estas pastagens apresentaram melhora em sua digestibilidade (aumento na DIVMS e PB e pequena diminuição no FDN) durante o inverno. A explicação para este aumento na lignina, poderia estar relacionado propriamente ao uso de nitrogênio, que possivelmente poderia aumentar a presença de material morto (folhas senescentes) durante o inverno e a presença de hastes no material coletado para análise bromatológica, como também relacionados aos maiores valores de taxa de senescência foliares encontrados quando do uso de dose maiores de nitrogênio. 
O uso de nitrogênio (Figuras 34 e 35) permitiu aumento nos teores de PB, DIVMO durante todo o período experimental, também aumento dos teores de lignina, talvez devido a maior presença de haste no material analisado, o que não influenciou os teores de FDN e FDA de maneira a não diminuírem a valores que permitiriam um efeito negativo do consumo desta forragem pelos animais .

Em trabalho desenvolvido por Teixeira (1998) em capim-Tobiatã sob pastejo rotacionado, adubado com $85 \mathrm{~kg} \mathrm{~N} \cdot \mathrm{ha}^{-1}$ após cada corte, mostrou que numa condição de pastejo simulado esta pastagem demonstrou tendência de redução na qualidade nutricional com o avançar da estação de pastejo até o mês de maio. O teor de lignina foi significativamente elevado na fração haste (planta toda e resíduo), com maior intensidade que nas folhas, sendo que este aumento com o avançar do pastejo poderia ser explicado pelo envelhecimento das mesmas, que por não serem consumidas tornavam-se mais rígidas após cada ciclo de pastejo .

Já Rosseto (2000) trabalhando com Panicum maximum cv. Tanzânia em sistema de produção de leite, adubado com $250 \mathrm{~kg} \mathrm{~N} \cdot \mathrm{ha}^{-1}$ dividido em quatro amostragens, mostrou que a partir de Março houve tendência de queda na composição bromotológica da forragem, sendo que esta mudança do valor nutritivo da forragem deve ter ocorrido provavelmente devido às alterações de ordem fisiológica (florescimento) e aumento da proporção de material morto que deveria estar contribuindo para a queda na DIVMO e no teor de PB neste período.

A quarta coleta apresentou os menores valores de PB em sua matéria seca (Figuras 34 e 35). Esta redução nos teores absorvidos de nitrogênio possivelmente foi causada pela maior presença de hastes foliares (devido ao florescimento) no material moído. Esse material originado da matéria seca total consistia da amostra usada para determinação da produção total (haste e folha), e que devido ainda à presença do florescimento no período, apresentaram diminuição nos teores totais de nitrogênio no material analisado, em função da menor participação das folhas (as quais estão presente a maior parte do nitrogênio absorvido) dentro deste material coletado para análise .

Outro fator envolvido, e que pode ter contribuído para a diminuição na absorção em nitrogênio, foi o "déficit" hídrico sofrido neste período, com a qualidade de 
forragem sendo menor em relação às demais coletas experimentais. Além dos menores teores de PB, a qualidade de forragem mostrou-se menor com a diminuição nos valores de DIVMO e aumento em FDA e lignina, como observado nas Figuras 34 e 35.

Trabalhos observando os diferentes tecidos (tecido vascular, esclerênquima e outros) presentes nas folhas e colmos, tem correlacionado a suas proporções com o valor nutritivo de gramíneas forrageiras.

Paciullo et al. (2000) avaliando correlações lineares entre características anatômicas e bromatológicas de folhas e colmos em três gramíneas (Brachiaria decumbens, Melinis minutiflora e Cynodon spp. cv. Tifton 85), observaram que os tecidos de baixa digestibilidade, como o tecido vascular e o esclerenquimático, se associam positivamente com a fração fibrosa da forragem (FDN, FDA e lignina),e negativamente com os teores protéicos e com a digestibilidade, principalmente quando agrupou-se os dados de lâmina e colmo. A correlação negativa entre lignina e digestibilidade, mostram a lignina como principal componente químico limitante da digestibilidade em forragens. Outro fator encontrado, como a elevada associação negativa entre espessura da parede celular e a digestibilidade, demonstra que problemas de natureza física poderiam diminuir a digestão da parede celular.

Paciullo et al. (1999) estudaram o efeito de três regimes hídricos em gramíneas Brachiaria decumbes e Brachiaria brizantha, na proporção de tecidos e a espessura da parede celular do esclerênquíma e dos vasos do metaxilema, verificaram aumento da espessura da parede celular do esclerenquíma com a redução do nível de umidade do solo. Os autores mostraram que dentro do período de escassez de água prolongado, este pode influir negativamente no valor nutritivo da forragem, considerando a hipótese de limitação da digestão da parede celular pelo seu aumento em espessura.

Como efeito fisiológico, causado por estresse hídrico, tem-se como o mais sensível à planta a redução na taxa de crescimento diário foliar, que foi observado por Roberts et al. (1990) em cana-de-açúcar somente três dias após o não uso de irrigação. 


\subsection{Análise econômica simples avaliando o uso do fertilizante aplicado}

Visando quantificar a rentabilidade econômica de quatro projetos constituídos de 12 piquetes de 1 hectare, dentro de um sistema de manejo de pastagem rotacionada, com taxa de ocupação de três dias e corte de piquete a cada 36 dias, considerando somente o uso do fertilizante nitrogendo e a capacidade de suporte máxima estimada em cada uma das nove coletas experimentais em pastagem de capim Tanzânia estabelecido numa Terra Roxa Estruturada, avaliados em área experimental da Fazenda Areão, Piracicaba, SP. A aplicação do nitrogênio via fertirrigação foi considerada, mas não contabilizada nos custos de produção estimados.

Para comparação de projetos, buscou-se comparar o preço de compra de dois fertilizantes nitrogenados Uréia (45\% N) e Sulfato de Amônio (20\%) em dois Estados brasileiro (Bahia e São Paulo), possibilitando estudar o papel do tipo de produto (na empresa distribuidora) e da concentração do nutriente no fertilizante dentro de uma análise econômica simples, desconsiderando itens como frete de transporte, custos do uso de irrigação e outros que são importantes e foram considerados por Pinheiro (2001) em uma análise econômica para um sistema de manejo rotacionado sob pivô central..

As determinações econômicas necessárias para o cálculo da receita líquida (RL) experimental, foram consideradas seguindo a mesma metodologia usada por Favoretto et al. (1988), em um estudo para verificar o efeito de três níveis de nitrogênio $(0,50$ e $100 \mathrm{~kg} \mathrm{~N} \cdot \mathrm{ha}^{-1}$ ) sobre a produção de capim colonião (P. maximum .).

As receitas líquidas estimadas em cada período experimental com capim Tanzânia, utilizando-se dois fertilizantes nitrogenados, (Uréia $(45 \%$ N) e Sulfato de Amônio $(20 \% \mathrm{~N})$, cotados em dois Estados brasileiros (Bahia e São Paulo), são apresentadas nas Figuras 36 e 37.

Com o uso de nitrogênio maiores produções de massa seca total são obtidas, as quais permitem um aumento na capacidade de suporte estimada, e assim uma elevação considerável na receita líquida obtida comparando ao tratamento sem fertilizante. 
Foram considerados os preços de fertilizantes nitrogenados, cotados em julho de 2002 no Estado da Bahia (Camaçari) ${ }^{3}$, nos valores de US\$ 148,39 para Uréia e US\$109,52 para Sulfato de Amônio e em São Paulo (Capital) ${ }^{3}$, nos valores de US\$ 292,23 para Uréia e US\$223,14 para Sulfato de Amônio.
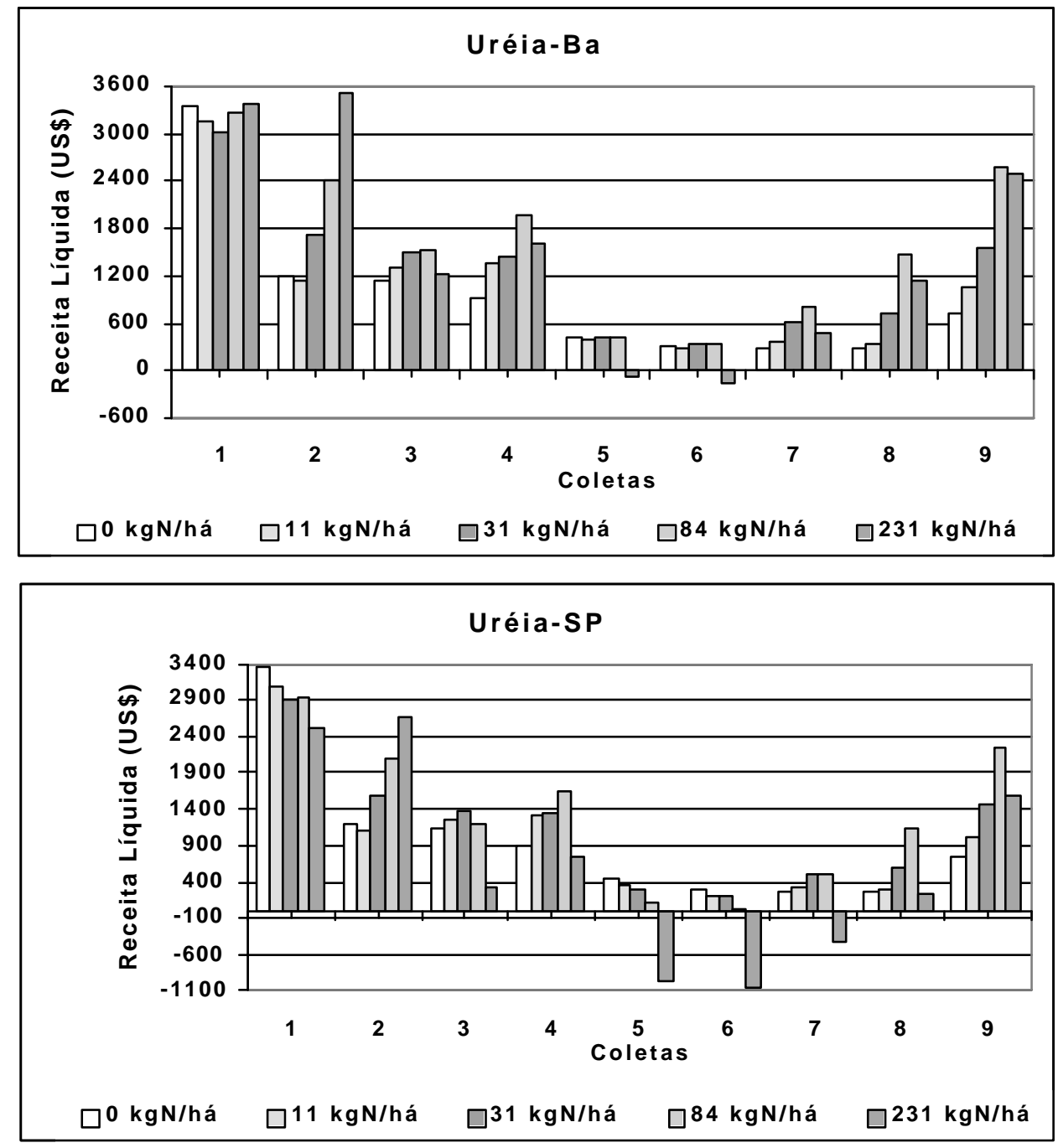

Figura 36- Receita líquida estimada em cada período de coleta experimental com capim Tanzânia, baseada na capacidade de suporte estimada no período, utilizando o fertilizante nitrogenado Uréia (45\% N) e cotado nos Estados da Bahia e São Paulo.

\footnotetext{
${ }^{3}$ Bahia - Petrofertil - Camacari ; São Paulo - Inst. de Economia Aplicada : http://www.iea.sp.gov.br
} 

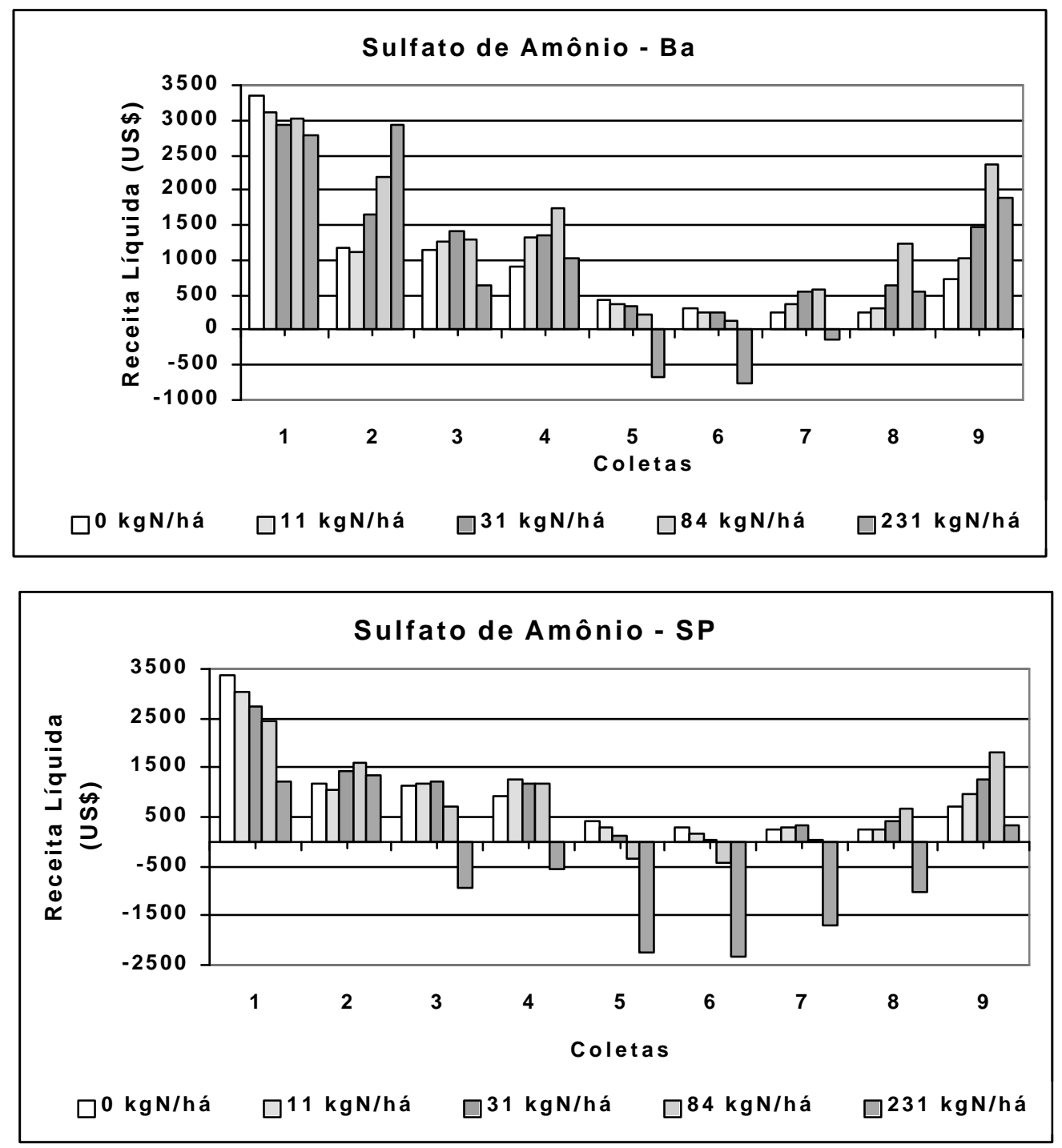

Figura 37- Receita líquida estimada em cada período de coleta experimental com capim Tanzânia, baseada na capacidade de suporte estimada no período, utilizando o fertilizante nitrogenado Sulfato de Amônio $(20 \%$ N) cotado nos Estados da Bahia e São Paulo.

Com o preço cotado na Bahia, o uso da Uréia (maior concentração de nitrogênio - 45\% N) para adubação de pastagem proporcionou maiores RL quando considerados todo o período experimental, do que quando foi feito uso do fertilizante Sulfato de Amônio (menor concentração de nitrogênio - 20\%N). 
O uso da maior dose de nitrogênio (231 kg N.ha ${ }^{-1}$ ) aplicada em cada coleta, proporcionaram no período mais frio (coletas 5, 6 e 7) (Figuras 36 e 37) e de menor desenvolvimento do capim receitas líquidas negativas, as quais se mostraram mais significativas quando utilizado Sulfato de Amônio.

O que deve ser considerado nesta análise econômica é que a RL obtida neste trabalho está sendo superestimada, uma vez que dependendo do tipo de fertilizante usado, o item frete teria um peso significativo neste cálculo, onde possivelmente menores RL seriam obtidos. Quando do uso do Sulfato de Amônio, maiores quantidades deste fertilizante são necessárias com o aumento da dosagem de nitrogênio usada na pastagem, devido a baixa concentração do nutriente nitrogênio neste fertilizante.

Com a estabilização da produção de massa seca total a partir da terceira coleta, e na presença de condições favoráveis ambientais e de crescimento para o capim Tanzânia (Coletas 3, 4, 8 e 9), o uso da dose de fertilizante nitrogenado de $84 \mathrm{~kg} \mathrm{~N}$.ha ${ }^{-1}$. período ${ }^{-1}$ (ou $756 \mathrm{~kg} \mathrm{~N} . \mathrm{ha}^{-1}$.ano ${ }^{-1}$ ) foi a que proporcionou maior RL, quando comparando as demais doses de nitrogênio.

O papel do maior preço de compra do fertilizante nitrogenado pode ser considerado quando se observam os maiores valores pagos pelos fertilizantes retirados no Estado de São Paulo, que contribuem para uma menor RL quando comparados àqueles de compras obtidos na Bahia (Figura 36 e 37). O efeito sobre a RL é mais significativo e negativo, quando observa-se o uso da dose máxima de nitrogênio e, quando considera-se o uso do fertilizante com menor concentração de nitrogênio (Sulfato de Amônio), durante os períodos de coletas experimentais estudados.

A renda líquida (US\$.coleta ${ }^{-1}$ ) obtida por quilograma de $\mathrm{N}$ aplicado em pastagem de capim Tanzânia, utilizando os fertilizantes nitrogenados Uréia $(45 \%$ N) e Sulfato de Amônio (20\%) nos Estados da Bahia e São Paulo são mostrados na Tabela 34.

A redução da receita líquida com o aumento da dose de nitrogênio utilizada em pastagem de capim Tanzânia, e o efeito do preço de compra e tipo de fertilizante usado, são mais claramente observados na Tabela 34, e apresentando como válidas as mesmas observações anteriormente discutidas. 
Tabela 34. Renda líquida (US\$.coleta ${ }^{-1}$ ) obtida por quilograma de $\mathrm{N}$ aplicado em pastagem de capim Tanzânia, utilizando-se os fertilizantes nitrogenados Uréia (45\% N) e Sulfato de Amônio (20\%), cotados nos Estados da Bahia e São Paulo.

\section{Uréia}

\begin{tabular}{|c|c|c|c|c|c|c|c|c|c|c|}
\hline \multirow{3}{*}{ Coletas } & \multicolumn{10}{|c|}{ Dose de $\mathrm{N}$ aplicado $\left(\mathrm{kg} \mathrm{N} \cdot \mathrm{ha}^{-1}\right.$. período $\left.^{-1}\right)$} \\
\hline & 0 & 11 & 31 & 82 & 231 & 0 & 11 & 31 & 82 & 231 \\
\hline & \multicolumn{5}{|c|}{ Bahia } & \multicolumn{5}{|c|}{ São Paulo } \\
\hline 1 & - & 285.4 & 98.7 & 38.7 & 14.7 & - & 281.6 & 94.9 & 34.9 & 10.9 \\
\hline 2 & - & 103.3 & 56.4 & 28.6 & 15.3 & - & 99.5 & 52.6 & 24.7 & 11.4 \\
\hline 3 & - & 118.2 & 48.9 & 18.1 & 5.3 & - & 114.4 & 45.0 & 14.2 & 1.5 \\
\hline 4 & - & 123.4 & 47.2 & 23.4 & 7.0 & - & 119.5 & 43.4 & 19.5 & 3.2 \\
\hline 5 & - & 36.3 & 14.0 & 5.1 & -0.4 & - & 32.5 & 10.1 & 1.2 & -4.2 \\
\hline 6 & - & 24.7 & 11.2 & 4.1 & -0.7 & - & 20.9 & 7.4 & 0.3 & -4.5 \\
\hline 7 & - & 35.1 & 20.5 & 9.7 & 2.0 & - & 31.2 & 16.6 & 5.8 & -1.8 \\
\hline 8 & - & 31.4 & 23.6 & 17.4 & 4.9 & - & 27.6 & 19.8 & 13.6 & 1.1 \\
\hline 9 & - & 96.5 & 50.9 & 30.7 & 10.8 & - & 92.7 & 47.1 & 26.9 & 7.0 \\
\hline
\end{tabular}

Sulfato de amônio

\begin{tabular}{|c|c|c|c|c|c|c|c|c|c|c|}
\hline \multirow{3}{*}{ Coletas } & \multicolumn{10}{|c|}{ Dose de $\mathrm{N}$ aplicado (kg N.ha ${ }^{-1} \cdot$ período $\left.^{-1}\right)$} \\
\hline & 0 & 11 & 31 & 82 & 231 & 0 & 11 & 31 & 82 & 231 \\
\hline & \multicolumn{5}{|c|}{ Bahia } & \multicolumn{5}{|c|}{ São Paulo } \\
\hline 1 & - & 282.8 & 96.1 & 36.1 & 12.1 & - & 276.0 & 89.3 & 29.3 & 5.3 \\
\hline 2 & - & 100.7 & 53.8 & 26.0 & 12.7 & - & 93.9 & 47.0 & 19.2 & 5.8 \\
\hline 3 & - & 115.6 & 46.2 & 15.4 & 2.7 & - & 108.8 & 39.4 & 8.6 & -4.1 \\
\hline 4 & - & 120.8 & 44.6 & 20.7 & 4.4 & - & 113.9 & 37.8 & 13.9 & -2.4 \\
\hline 5 & - & 33.7 & 11.4 & 2.5 & -3.0 & - & 26.9 & 4.5 & -4.4 & -9.8 \\
\hline 6 & - & 22.1 & 8.6 & 1.5 & -3.3 & - & 15.3 & 1.8 & -5.3 & -10.1 \\
\hline 7 & - & 32.5 & 17.9 & 7.1 & -0.6 & - & 25.6 & 11.1 & 0.2 & -7.4 \\
\hline 8 & - & 28.8 & 21.0 & 14.8 & 2.3 & - & 22.0 & 14.2 & 8.0 & -4.5 \\
\hline 9 & - & 93.9 & 48.3 & 28.1 & 8.2 & - & 87.1 & 41.5 & 21.3 & 1.4 \\
\hline
\end{tabular}

A receita líquida anual (US\$) obtida em pastagem de capim Tanzânia, utilizando os fertilizantes nitrogenados Uréia (45\% N) e Sulfato de Amônio (20\%), e com preços cotados nos Estados da Bahia e São Paulo, são mostrados na Figura 38. As equações de regressões resultantes desta receita líquida anual, considerando-se as dosagens anuais de nitrogênio usados na pastagem de capim Tanzânia, são apresentados na Tabela 35. 

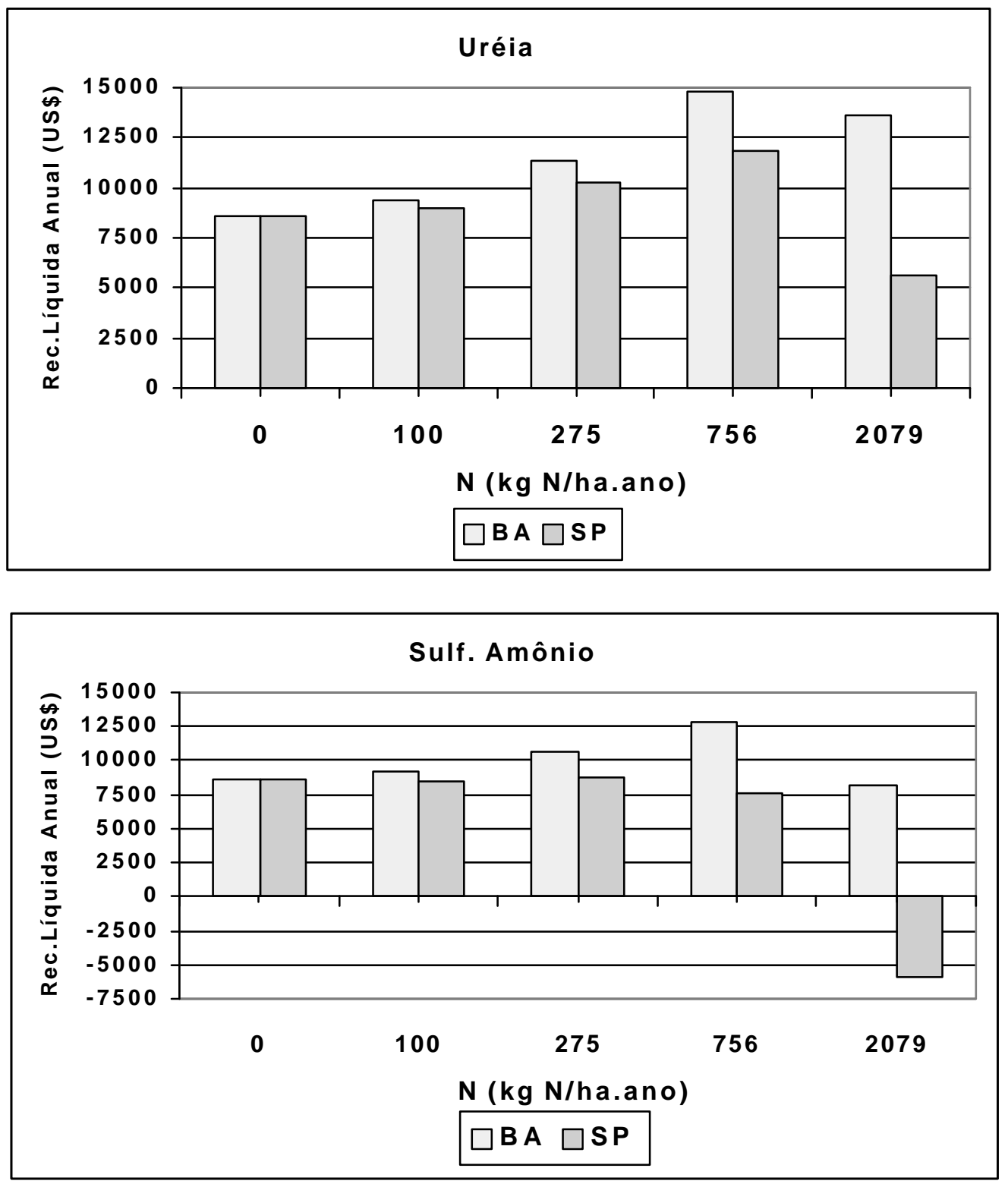

Figura 38 - Renda líquida anual (US\$) obtida em pastagem de capim Tanzânia, utilizando os fertilizantes nitrogenados Uréia (45\% N) e Sulfato de Amônio (20\%), com preços cotados nos Estados da Bahia e São Paulo. 
Tabela 35. Equações de regressão para renda líquida anual (US\$.ano ${ }^{-1}$ ) para dois tipos de fertilizantes nitrogenados (Uréia e Sulfato de Amônio), preços cotados nos Estados da Bahia e São Paulo, e suas doses e renda líquida máxima em pastagem de capim Tanzânia estabelecido numa Terra Roxa Estruturada, avaliados em área experimental da Fazenda Areão, Piracicaba, SP.

\begin{tabular}{|c|c|c|c|c|c|}
\hline $\begin{array}{c}\text { Tipo de } \\
\text { Fertilizante } \\
\text { Nitrogenado }\end{array}$ & Estado & Equação & $\mathrm{R}^{2}$ & $\begin{array}{c}\text { Máxima } \\
\text { Receita } \\
\text { Líquida } \\
(\text { US\$.ano-1) }\end{array}$ & $\begin{array}{l}\text { Dose N para } \\
\text { máxima RL }{ }^{(1)} \\
\left(\mathrm{kg} \mathrm{N} \cdot \mathrm{ha}^{-1} \cdot \mathrm{ano}^{-1}\right)\end{array}$ \\
\hline \multirow[t]{2}{*}{ Uréia } & $\overline{\mathrm{BA}}$ & $8.457,60+11,63 X-0,00439 X^{2}$ & 0,9928 & $16.154,96$ & $1.323,34$ \\
\hline & SP & $8.459,51+7,79 X-0,00439 X^{2}$ & 0,9908 & $11.915,64$ & 886,89 \\
\hline Sulfato de & BA & $8.458,66+9,02 X-0,00439 X^{2}$ & 0,9859 & $13.084,05$ & $1.025,91$ \\
\hline Amônio & SP & $8.461,41+2,19 X-0,00439 X^{2}$ & 0,9989 & $8.735,59$ & 249,83 \\
\hline
\end{tabular}

Conforme observado na Tabela 22, as doses de nitrogênio que proporcionariam a máxima produção de massa seca total e foliar seriam de $1.768,75 \mathrm{~kg} \mathrm{~N} \cdot \mathrm{ha}^{-1} \cdot \mathrm{ano}^{-1} \mathrm{e}$ $1.586,17 \mathrm{~kg} \mathrm{~N} \cdot \mathrm{ha}^{-1} \cdot \mathrm{ano}^{-1}$, mas quando considerado a concentração de nutriente no fertilizante e o preço pago pelo produto pelo pecuarista $(\mathrm{FOB})^{4}$, as doses de nitrogênio recomendadas para uma aplicação anual em área de pastagem tendem a ser menores às dosagens anteriormente recomendadas, como mostrado na Tabela 35 .

Com a simples diferença de preço de compra da Uréia (preços cotado na BA e SP), a dosagem recomenda para uma máxima receita líquida anual com o preço comercializado na Bahia $\left(1.323,34 \mathrm{~kg} \mathrm{~N} \cdot \mathrm{ha}^{-1} . \mathrm{ano}^{-1}\right)$ permitiriam uma receita significativa de aproximadamente US\$ 4.239,31, quando considerado como escolha para trabalho um adubo somente com maior concentração .

Quando da disponibilidade somente do Sulfato de Amônio para compra pelo produtor, a dosagem de nitrogênio recomendada para uso na pastagem não deverá ser superior a $250 \mathrm{Kg} \mathrm{N} \cdot \mathrm{ha}^{-1}$.ano ${ }^{-1}$ ao preço cotado como encontrado no Estado de São

\footnotetext{
${ }^{4}$ free on board - o preço da mercadoria não inclui o frete nem o seguro ou outras despesas, que correm por conta do comprador
} 
Paulo, onde a receita líquida seria de aproximadamente de US\$ 7.419,37 menor , quando comparado ao uso de Uréia cotado na Bahia.

A relação entre preço de compra e o teor de nutriente no fertilizante comprado tende a ser o fator a ser considerado mais preponderantemente pelo pecuarista, quando do momento de aquisição do fertilizante nitrogenado para adubação de pastagem de capim Tanzânia.

O uso de uma planilha para contabilização de todos os custos e que possa maximizar a receita líquida na atividade de pecuária deve ser considerada pelo produtor no seu uso diário, uma vez que dependendo da localização da propriedade agrícola o uso de uma tecnologia como irrigação e adubação das pastagens pode se tornar uma opção dispendiosa para a atividade escolhida.

O efeito climático (variação de temperatura e fotoperíodo) pode também contribuir de maneira positiva para um aumento da produção de massa seca da pastagem, e assim influir para o aumento da receita líquida quando do uso destas tecnologias de incremento para as produções escolhidas, como o uso de irrigação e adubação. 


\section{CONCLUSÕES}

\section{Variação climática e de solo na planta}

- O efeito da lâmina de irrigação para a massa seca total quando consideradas as doses de nitrogênio e épocas de coleta, dentro das três estações estudadas, somente foram significativos nas $1^{\mathrm{a}}$ e $4^{\mathrm{a}}$ coletas, efeito negativo e positivo respectivamente.

- com a diminuição do teor de umidade em profundidade e a não ascensão de água para a superfície do solo para suprir as raízes superficiais durante a quarta coleta experimental, respostas para o efeito de uso de lâminas de irrigação em pastagem com capim Tanzânia foram encontradas.

- A ocorrência da estacionalidade na produção de massa seca total em Piracicaba é algo característico da região, a qual é afetada principalmente por fatores climáticos como temperatura e fotoperíodo, onde o efeito da irrigação como manejo complementar no inverno e o uso de nitrogênio para aumentar a produção do capim Tanzânia não se mostraram capazes de compensar o efeito clima, desfavorável.

\section{Produção de massa seca}

- O efeito de uso de doses de nitrogênio, mostrou-se significativo para a produção de massa seca total, foliar e de hastes nas três estações estudadas. Uma tendência linear para produção de massa seca total com a aplicação de nitrogênio quando variando as diferentes lâminas de irrigação usadas, e de efeitos quadráticos e lineares para o uso de nitrogênio sobre a produção de massa seca foliar e de hastes foram encontrados .

- O uso de doses de nitrogênio acima daquela considerada ótima para a produção de massa seca foliar (MDMS), proporcionoum uma aumento na fração de haste (colmo, hastes, material senecido) na massa seca total. 
- As estações de inverno, primavera e verão mostram-se como a seqüência natural de aumento nas produções de massa seca totais e foliares, quando considerado os ciclo anuais de crescimento para o capim Tanzânia.

- Quando do uso das lâminas de irrigações, onde já para quando do uso de nitrogênio produções foram estimadas em 9.545, 11.195, 13.866 e $19.639 \mathrm{~kg}$ ${\mathrm{MS} . h a^{-1} \text {.ano }}^{-1}$ para massa seca total, e de 8.125, 9.569, 11.869, 16710 e $18.808 \mathrm{~kg}$ MS.ha $^{-1} \cdot$ ano $^{-1}$ para massa seca foliar, quando utilizado zero, 100, 275, 756 e 2079 $\mathrm{kg} \mathrm{N} \cdot \mathrm{ha}^{-1} \cdot$ ano $^{-1}$, respectivamente .

- $\mathrm{O}$ uso de dosagens de nitrogênio superiores a $756 \mathrm{KgN} \cdot \mathrm{ha}^{-1} \cdot \mathrm{ano}^{-1}$ não proporcionaram efeitos crescentes sobre a produção de massa seca, sendo que os percentuais de incrementos nas produções proporcionadas pelo uso de nitrogênio até a máxima produção de massa seca total e foliar, mostraram ser de 15, 19, 29, 20 $\%$ (16\% foliar), quando usado as doses de 100, 275, 756 e $1.769 \mathrm{~kg} \mathrm{~N} \cdot \mathrm{ha}^{-1}$.ano ${ }^{-1}$.

\section{Eficiência de uso de água e nitrogênio}

- Em condição de déficit hídrico (quarta coleta) os valores de EUA foram superiores as demais coleta, mostrando um melhor uso da água disponível e nutrientes pelas plantas.

- Os valores de EUA dentro das lâminas de irrigação aplicadas mostraram uma redução com as maiores da lâmina de irrigação, sendo o tratamento de $70 \% \mathrm{CC}$ aquele que proporcionou os maiores valores de EUA nas coletas efetuadas.

- Com a variação das doses de nitrogênio dentro de cada lâmina estabelecida após sucessivos cortes, os valores de EUA tenderam a uma redução, sendo mais claro quando do aumento da lâmina de irrigação usada. 
- O aumento das doses de nitrogênio dentro dos diferentes períodos de coletas, permitiram aumentos nas produções de massa seca total, e aumento nos valores de concentração de nitrogênio total e nitrogênio absorvido, os quais foram influenciadas pelos diferentes momentos climáticos, apresentando, sendo que as concentrações de nitrogênio total nas plantas ficaram sempre acima do valor crítico de $1,1 \% \mathrm{~N}$.

- A eficiência de uso do nitrogênio (EUN) e a EFNabs pelo capim Tanzânia apresentaram uma tendência de redução em seus valores com o aumento da dose de fertilizante nitrogenado, sendo que o uso de doses de nitrogênio até o máximo de $275 \mathrm{~kg} \mathrm{~N} \cdot \mathrm{ha}^{-1}$.ano ${ }^{-1}$ mostraram maiores EUN e EFNabs do que quando usados doses acima de $756 \mathrm{~kg} \mathrm{~N} \cdot \mathrm{ha}^{-1}$.ano ${ }^{-1}$, a qual proporcionou maior porcentagem de nitrogênio recuperado (40\% quando irrigado e de $33 \%$ não irrigado).

- A dose de nitrogênio recomendada para perda zero de nitrogênio dentro de cada período de coleta, seriam de aplicações de 64, 37, 25, 14, 9, 7, 11, 14 e $21 \mathrm{~kg} \mathrm{~N}$.ha $^{-}$ ${ }^{1}$.período ${ }^{-1}$ entre coleta 1 a 9 , o que totalizaria uma quantidade de $202 \mathrm{~kg} \mathrm{~N}$.ha ${ }^{-}$ ${ }^{1}$.ano ${ }^{-1}$ e uma produção média de massa seca total de $13.362 \mathrm{~kg} \mathrm{MS.ha-1}$.ano ${ }^{-1}$, quando usado uma lâmina de irrigação suprindo 70 \% da capacidade de campo.

\section{Análise Bromatológica}

- De maneira geral, o uso de nitrogênio proporcionou aumento no teor de proteína bruta das plantas que receberam adubação a partir de $275 \mathrm{~kg} \mathrm{~N} \cdot \mathrm{ha}^{-1}$, como também nos valores de digestibilidade 'in vitro' da matéria orgânica (DIVMO), o qual se relaciona a uma matéria seca de melhor qualidade, com valores de FDN e FDA próximos aqueles encontrados em tecidos novos .

- $\quad$ O uso de nitrogênio durante todos os períodos de coletas proporcionou aumento na quantidades de PB presente na pastagem, como também aumento nos valores de digestibilidade "in vitro" da matéria orgânica (DIVMO) apresentando uma 
diminuição de digestibilidade da pastagem ofertada entre a quarta e sétima coleta influenciada pelos efeitos do clima

- Com o uso de $756 \mathrm{~kg} \mathrm{~N} \cdot \mathrm{ha}^{-1} \cdot$ ano $^{-1}$, observou-se uma melhora na qualidade da forragem, com aumento de PB e DIVMO, não variação do FDA e melhora na ingestão no inverno com a diminuição dos valores de FDN; relação inversa foi obtida quando do não uso de nitrogênio.

- O aumento de lignina (devido a hastes e material morto (folhas senescentes) no material de análise bromatológica) nos períodos de inverno e primavera para as duas maiores adubações nitrogenadas (756 e $2076 \mathrm{~kg} \mathrm{~N} . \mathrm{ha}^{-1} . \mathrm{ano}^{-1}$ ), não apresentaram relação com os índices DIVMO, FDN e FDA

\section{Análise de Custos}

- A relação entre preço de compra e o teor de nutriente no fertilizante deve ser o fator preponderantemente a ser considerado pelo pecuarista, quando do momento de aquisição do fertilizante nitrogenado para adubação de pastagem de capim Tanzânia.

- O uso de uma fonte de fertilizante com maior concentração de nitrogênio proporcionou maiores RL quando comparadas àquele em menor concentração de nitrogênio.

- O maior preço de compra do fertilizante nitrogenado pode contribuir na rentabilidade do empreendimento, sendo que a dimuinuição da RL é mais significativa, quando associa-se a dose máxima de nitrogênio com fertilizantes com baixa concentração em nitrogênio. 
Anexos 


\section{Anexo A}

PERFIL - 01 DATA:O6/05/97

CLASSIFICAÇÃO: Terra Roxa Estruturada eutrófî caA moderado textura argilosa. LOCALIIZAÇÃO: Estado de São Paulo, município de Piracicaba, Fazenda Areão, Área Experimental de Irrigação do Departamento de Engenharia Rural, à $50 \mathrm{~m}$ à leste das estufas.

SITUAÇÃO E DECLIVE: P erfil descrito em uma trincheira, sob condições de vegetação artificial de mangueira, em declive suave ondulado.

ALTITUDE: $550 \mathrm{~m}$ aproximadamente.

LITOLOGIA E FORMAÇÃO GEOLÓGICA: Diabásio.

MATERIAL ORIGINÁRIO: saprólito do Diabásio.

PEDROGOSIDADE E ROCHOSIDADE: Ausente.

RELEVO LOCAL - suave ondulado.

REGIONAL - suave ondulado

EROSÃO: laminar severa.

DRENAGEM: Bem drenado.

USO ATUAL.: cultivado com mangueira, limão e outras culturas anuais.

Descrição do Perfil .

Ap - 0 a $10 \mathrm{~cm}$; bruno avermelhado escuro (2,5YR 3/4, úmido ). bruno avermelhado escuro (2,5YR 3/4 seco); franco argiloso; composta de grãos individuais e fraca grande granular; muitos poros grandes e médios; ligeiramente duro, friável, ligeiramente plástico e ligeiramente pegajoso; transição clara e plana.

BA - 10 a $20 \mathrm{~cm}$; bruno avermelhado escuro ( .SYR 31 , úmido), bruno avermelhado escuro (2,SYR 3/4, seco); argila; forte média em blocos angulares: poros comuns pequenos e médios; muito duro, friável, plástico pegajoso; transição difusa e plena. 
Btl - 20 a $56 \mathrm{~cm}$; bruno avermelhado escuro (2,5YR 3/4, úmido). vermelho escuro (2,5YR 3/6 seco); forte média em blocos angulares; poros comuns pequenos e médios; cerosidade moderada e comum; muito duro. friável, plástico pegajoso ; transição difusa e plana.

Bt2 - 56 a $97 \mathrm{~cm}$; bruno avermelhado escuro (2,5YR 3/4úmido) vermelho escuro (2,5 YR 3/6 , seco); argila; moderada média e grande em blocos angulares; muitos poros pequenos; cerosidade moderada e comum; muito duro, friável, plástico e pegajoso; transição difusa e plana.

Bt3 - 97 a 127 cm; vermelho escuro ( 2,5 YR 3/6, úmido ). vermelho escuro ( 2,5 YR 3/6, seco ); argila; moderada a forte média e grande em blocos angulares, muitos poros pequenos; duro, friável, ligeiramente plástico e ligeiramente pegajoso; transição gradual e plana.

BC - 127 a 170+ cm; vermelho escuro (2,5 YR 3/6 úmido ), vermelho (2,5 YR 4/6, seco); argila; fraca pequena e média em blocos angulares; muitos poros pequenos: ligeiramente duro, friável, ligeiramente plástico e ligeiramente pegajoso.

RAÍZES: Muitas fasciculadas e pivotantes, médias e finas em Ap e AB; poucas pivotantes finas e médias em Bt1 e Bt2; raras pivotantes e finas e médias em Bt3 e BC.

EXAMINADORES: Francisco Ocian B. Mota e José Francismar de Medeiros. 
Anexo B. Equações de regressão para variação de dose de adubação nitrogenada dentro de cada lâmina de irrigação e coleta, em três estações climáticas para a matéria seca folha em pastagem de capim Tanzânia estabelecido numa Terra Roxa Estruturada, avaliados na Fazenda Areão, Piracicaba, SP.

\begin{tabular}{|c|c|c|c|c|c|c|c|c|c|}
\hline \multirow{2}{*}{ Lâmina ${ }^{(1)}$} & \multirow[b]{2}{*}{ Coleta } & \multicolumn{2}{|l|}{ Verão } & \multicolumn{4}{|c|}{ Inverno } & \multicolumn{2}{|c|}{ Primavera } \\
\hline & & Equação & $\mathrm{R}^{2}$ & Coleta & Equação & $\mathrm{R}^{2}$ & Coleta & Equação & $\mathrm{R}^{2}$ \\
\hline 0 & & $4.398,16-0,49 X$ & $0,22^{@}$ & & NS & - & & NS & - \\
\hline 30 & & $2.967,16+0,91 X$ & $0,46^{* *}$ & & NS & - & & NS & - \\
\hline 70 & 1 & NS & - & 4 & NS & - & 7 & NS & - \\
\hline 100 & & $2.549,03+0,79 X$ & $0,81^{* *}$ & & NS & - & & NS & - \\
\hline 150 & & $952,60+0,88 X$ & $0,77^{* *}$ & & NS & - & & NS & - \\
\hline 0 & & $1.423,72+1,64 X$ & $0,97^{* * *}$ & & NS & - & & NS & - \\
\hline 30 & & $1.244,94+3,76 X-0,0014 X^{2}$ & $0,67^{*}$ & & NS & - & & NS & - \\
\hline 70 & 2 & $1.584,98+1,44 X$ & $0,91^{* *}$ & 5 & NS & - & 8 & NS & - \\
\hline 100 & & $784,56+4,49 X-0,0015 X^{2}$ & $0,91^{*}$ & & NS & - & & NS & - \\
\hline 150 & & $1.445,11+1,32 X$ & $0,86^{* * *}$ & & NS & - & & NS & - \\
\hline 0 & & NS & - & & NS & - & & NS & - \\
\hline 30 & & NS & - & & NS & - & & NS & - \\
\hline 70 & 3 & $852,68+2,77 X-0,0012 X^{2}$ & $0,97^{*}$ & 6 & NS & - & 9 & NS & - \\
\hline 100 & & $1.414,29+0,49 X$ & $0,46^{@}$ & & NS & - & & NS & - \\
\hline 150 & & $952,60+0,88 X$ & $0,77^{* *}$ & & NS & - & & NS & - \\
\hline
\end{tabular}

1- \% da capacidade de campo.

@ $\mathrm{p}<0,10 ; * \mathrm{p}<0,05 ; * * \mathrm{p}<0,01 ; * * * \mathrm{p}<0,001 ; \mathrm{NS}-$ Não significativo 
Anexo C. Equações de regressão para variação de dose de adubação nitrogenada dentro de cada lâmina de irrigação e coleta, em três estações climáticas para a matéria seca de hastes em pastagem de capim Tanzânia estabelecido numa Terra Roxa Estruturada, avaliados na Fazenda Areão, Piracicaba, SP.

\begin{tabular}{|c|c|c|c|c|c|c|c|c|c|}
\hline \multirow[b]{2}{*}{ Lâmina ${ }^{(1)}$} & \multirow[b]{2}{*}{ Coleta } & \multicolumn{2}{|c|}{ Verão } & \multicolumn{3}{|c|}{ Inverno } & \multicolumn{3}{|c|}{ Primavera } \\
\hline & & Equação & $\mathrm{R}^{2}$ & Coleta & Equação & $\mathrm{R}^{2}$ & Coleta & Equação & $\mathrm{R}^{2}$ \\
\hline 0 & & NS & - & & NS & - & & NS & - \\
\hline 30 & & NS & - & & NS & - & & NS & - \\
\hline 70 & 1 & NS & - & 4 & NS & - & 7 & NS & - \\
\hline 100 & & NS & - & & NS & - & & NS & - \\
\hline 150 & & NS & - & & NS & - & & NS & - \\
\hline 0 & & NS & - & & NS & - & & NS & - \\
\hline 30 & & NS & - & & NS & - & & NS & - \\
\hline 70 & 2 & NS & - & 5 & NS & - & 8 & NS & - \\
\hline 100 & & NS & - & & NS & - & & NS & - \\
\hline 150 & & NS & - & & NS & - & & NS & - \\
\hline 0 & & NS & - & & NS & - & & NS & - \\
\hline 30 & & NS & - & & NS & - & & NS & - \\
\hline 70 & 3 & NS & - & 6 & NS & - & 9 & NS & - \\
\hline 100 & & NS & - & & NS & - & & NS & - \\
\hline 150 & & NS & - & & NS & - & & NS & - \\
\hline
\end{tabular}

NS - Não significativo 


\section{REFERÊNCIAS BIBLIOGRÁFICAS}

ADÁMOLI, J.; MACÊDO, J.; AZEVEDO, L.G. de; NETTO, J.M. Caracterização da região dos Cerrados. In: GOEDERT, W. J. Solos dos cerrados : tecnologias e estratégias de manejo. São Paulo:Nobel, 1985. cap. 2, p. 33-74.

ADDISON, K.B.; CAMERON, D.G.; BLIGHT, G.W. Effects of three level of nitrogen and mowing on pasture and animal production from spring/summer grazed Panicum maximum cv. trichoglume(Green Panic) pastures. Tropical Grasslands, v.19, p.59-68, 1985.

AGUIAR, A.P.A. Possibilidades de intensificação do uso da pastagem através de rotação sem ou com uso mínimo de fertilizantes . In: SIMPÓSIO SOBRE MANEJO DA PASTAGEM, 14. , Piracicaba, 1997. Anais. Piracicaba:FEALQ , 1997. p. 85138.

ALVIM, M.J.; BOTREL, M.A.; NOVELLY, P.E. Produção de gramíneas tropicais e temperadas, irrigada na época da seca. Revista da Sociedade Brasileira de Zootécnia, v.15, n.5, p. 384-393, 1986.

ALVIM, M.J.; SIMÃO NETO, M.; DUSI, G A. Efeito da disponibilidade de forragem e da adubação em pastagem de capim-angola sobre a produção de leite. Pesquisa Agropecuária Brasileira, v.27, n.11, p.1541-1550, 1992. 
ALVIM, M.J.; MARTINS, C.E.; BOTREL, M.A.; SALVATI, J.A.; JACOB, M.A.M. Efeito da irrigação e da integração entre pastagens de setária e de azevém anual sobre a produção de leite. Pesquisa Agropecuária Brasileira, v.28, n.4, p.545-554, 1993.

ARARAT, E.; TAFUR, H. Efectos de la interaccion riego-fertilizacion sobre la produccion de forraje en tres pastos de corte. Acta Agronomica, v. 40, n.1/2, p.158-161, 1990.

ARONOVICH, S. O capim colonião e outros cultivares de Panicum maximum Jacq. : Introdução e evolução do uso no Brasil. In: SIMPÓSIO SOBRE MANEJO DA PASTAGEM, 12. , Piracicaba, 1995. Anais. Piracicaba:FEALQ ,1995. p. 1-20.

ASSENG, S.; TURNER,N.C.; KEATING,B.A. Analysis of water- and nitrogen-use efficiency of wheat in a Mediterranean climate. Plant and Soil, v.233, p.127-143, 2001.

ASSOCIATION OF OFFICIAL ANALYTICAL CHEMISTS. Official methods of analysis. 16.ed. Washington, 1995. 2v.

BARKER, D.J.; SULLIVAN, C.Y.; MOSER, L.E. Water deficit effects on osmotic potencial, cell wall elasticity, and proline in five forage grasses. Agronomy Journal, v.85, p.270-275, 1993.

BENBI, D.K. Efficiency of nitrogen use by dryland wheat in a subhumid region in relation to otimizing the amount of available water. Journal of Agricultural Science, v.115, p.7-10, 1990. 
BERGAMASCHI, H. Desenvolvimento de déficit hídrico em culturas.. In: BERGAMASCHI, H.; BERLATO, M.A.; MATZENAUER, R.; FONTANA, D.C.; CUNHA, G. R.; SANTOS, M. L. V .dos ; FARIAS, J. R .B.; BARNI,N.A. (Coord.) Agrometeorologia aplicada à irrigação . Porto Alegre:Editora da Universidade, 1999. cap. 2, p.25-32.

BRUYN, L.A.L.; KINGSTON, T.J. Effects of summer irrigation and trampling in dairy pastures on soil physical properties and earthworm number and species composition. Australian Journal of Agriculturae and Research, v. 48, p.1059-1079, 1997.

CAMERON, D.G.; BISHOP, H.G.; WEEKS, P.J.; WEBB, A.A. Effects of irrigation, defoliation, associated grass and nitrogen on lucerne (Medicago sativa) as a component of pastures in sub-coastal central Queensland. Tropical Grasslands, v.24, p.75-80, 1990.

CARO-COSTAS, R.; ABRUÑA,F. ; FIGARELLA,J. Effect to nitrogen rates, harvest interval and cutting heights on yield and composition of Star grass in Puerto Rico. The Journal of Agriculture of the University of Puerto Rico, v.56, p.171-186, 1972

CARRIEL, J.M; PEDREIRA, J.V.S; MATTOS, H.B. Estimativa da ocorrência dos principais capins no Estado de São Paulo. Zootecnia, v. 17,n.1, p.5-25, 1979.

CARVALHO, D.D.; DAMASCENO, J. C. Aspectos fisioógicos do capim-elefante cv.Roxo de Botucatu. In: REUNIÃO ANUAL DA SOCIEDADE BRASILEIRA DE ZOOTECNIA, 33., Fortaleza, 1996. Anais. Fortaleza: SBZ, 1966, http://www.sbz.org.br/eventos/Fortaleza/Forragicultura/Sbz026.pdf (12 nov. 2002). 
CARVALHO, S.R.; SILVA, A.T.; COSTA, F.A.; SOUTO, S.M.; LUCAS, E.D. Influência da irrigação e da adubação em dois cultivares de capim elefante (Pennisetum purpureum). Pesquisa Agropecuária Brasileira, v. 10, p.23-30, 1975.

CHADHOKAR, P.A. Effect of rate and frequency of nitrogen aplication on dry matter yield and nitrogen content of Para grass (Brachiaria mutica). Tropical Grasslands, v.22, n.2, p.127-132, 1978.

CORREA, L. A. ; FREITAS, A R. de; BATISTA, L. A R. Níveis de nitrogênio e frequiências de corte em 12 gramíneas forrageiras tropicais. II - Qualidade de Forragem. In: REUNIÃO ANUAL DA SOCIEDADE BRASILEIRA DE ZOOTECNIA, 35. , Botucatu, 1998. Anais. Botucatu:SBZ, 1998. p. 518-520.

CORSI, M. Manejo das plantas forrageiras do gênero Panicum . In: SIMPÓSIO SOBRE MANEJO DA PASTAGEM, 9., Piracicaba, 1988. Anais. Piracicaba: FEALQ, 1988. p. 57-75.

CORSI, M. Adubação nitrogenada das pastagens. In: : PEIXOTO, A.M.; MOURA, J.C. DE; FARIA, V. P. de (Ed.). Pastagens : fundamentos da exploração racional. 2 ed. Piracicaba: FEALQ, 1994. p.121-153. (Série Atualização em Zootecnia, 10).

CORSI,M.; NUSSIO, L.G. Manejo do capim elefante: correção e adubação do solo. In: SIMPÓSIO SOBRE MANEJO DA PASTAGEM, 10., Piracicaba, 1993. Anais. Piracicaba: FEALQ, 1993. p. 87-115.

COSTA, C.; MONTEIRO, A. L. G.; OLIVEIRA, P.S.R. de; ALMEIDA JUNIOR, G.A. Correção do solo e estabelecimento da pastagem. In: SIMPÓSIO SOBRE MANEJO DA PASTAGEM, 18., Piracicaba, 2001. Anais. Piracicaba: FEALQ, 2001. p. 87127. 
CUNHA, M.K.; SIEWERDT, L.; SILVEIRA JUNIOR, P. ; SIEWERDT,F. Doses de nitrogênio e enxofre na produção e qualidade da forragem de campo natural de planossolo no Rio Grande do Sul . Revista Brasileira de Zootecnia, v.30, n.3, p.651-658, 2001.

DIAS, P.F; ROCHA, G.P. ; OLIVEIRA, A. I. G.; PINTO, J.C.; ROCHA FILHO, R.R.; SOUTO, S.M. Produtividade e qualidade de gramíneas forrageiras tropicais sob adubação nitrogenada no final do período das águas. Pesquisa Agropecuária Brasileira, v.33, n.7, p.1191-1197, 1998.

DIAS FILHO, M.B; CORSI, M.; CUSATO, S. Concentration, uptake and use efficiency of N, P and K in Panicum maximum Jacq. cv. Tobiatã under water stress. Pesquisa Agropecuária Brasileira, v. 27, n.3, p.381-387, 1992.

DOBERMANN, A. ; FAIRHURST, T. Rice : nutrient disorders \& nutrient management. Singapura:Potash \& Phosphate Institute; East \& Southeast Asia Programs, 2000. 191p.

DODD,M.B.; LAVENROTH, W.K.; BURKE, I.C. Nitrogen availability through a coarse-textured soil profile un the shortgrass steppe. Soil Science Society of America Journal, v.64, p.725-736, 2000.

DONAGHY, D.J.; SCOTT, J.M.; FULKERSON, W.J. Effects of desfoliation frequency and summer irrigation on survival of perennial (Lolium perenne) and biennial (Lolium multiflorum) ryegrass in the subtropics. Australian Journal of Experimental Agriculture, v. 37, p.537-545, 1997.

DOORENBOS, J.; KASSAM, A.H. Efeito da água no rendimento das culturas..

Trad. de H.R. Gheyi. Campina Grande: Universidade Federal da Paraíba;FAO, 1994. 306p. (Estudos FAO. Irrigação e Drenagem ,33). 
DOVE, H. The ruminant, the rumen and the pasture resource: nutrient interactions in the grazing animal. In: HODGSON, J.; ILLIUS, A.W. The ecology and management of grazing systems. New York: CAB International, 1996. cap. 8, p.219-246.

DOVRAT, A.; COHEN, Y; GOLDMAN, A. Irrigated forage production. Amsterdam: Elsevier Science, 1993. 257p. (Developments in Crop Science , 24).

EASTIN,J. D; SULLIVAN, C.Y. Environmental stress influences on plant persistence physiology, and production. In: TESAR, M.B. Physiological basis of crop growth and development. Madison: American Society of Agronomy, 1984. cap.8, p.201236.

EUCLIDES, V.P.B. Valor alimentício de espécies forrageiras do gênero Panicum. In: SIMPÓSIO SOBRE MANEJO DA PASTAGEM, 12., Piracicaba, 1995. Anais. Piracicaba: FEALQ, 1995. p.245-276.

FARDAD, H.; PESSARAKLI,M. Biomass production and water use efficiency of barley and wheat plants with different irrigation intervals at various water levels. Journal of Plant Nutrition, v.18, n.12, p.2643-2654, 1995.

FAVORETTO, V.; RODRIGUES, L.R.A.; TUPINAMBÁ, L.F. Efeito do nitrogênio na produção e composição bromatológica do capim colonião e seus aspectos econômicos. Científica, v.16, n.1, p. 71-78, 1988. 
FORNI, S.; MICHEL FILHO, L.C.; FAVORETTO,V.; MALHEIROS,E.B. Efeito de estratégias de adubação com NPK sobre a produção, qualidade e estrutura das cultivares Tanzânia e Mombaça de Panicum maximum Jacq.. In: REUNIÃO ANUAL DA SOCIEDADE BRASILEIRA DE ZOOTECNIA, 37., Viçosa, 2000. Anais. Viçosa: SBZ, 2000. http://www.sbz.org.br/anais 2000/Forragem/702.pdf (30 jul. 2002)

GARABET, S. ; WOOD, M.; RYAN, J. Nitrogen and water effects on wheat yield in a Mediterranean-type climate I. Growth, water-use and nitrogen accumulation. Field Crops Research, v.57, p.309-318, 1998.

GARCIA, J. A. R. Efeito de diferentes lâminas d'água sobre a cultura da aveia irrigada por inundação temporária. Lavras, 1993. 71 p. Dissertação (Mestrado) - Escola Superior de Agricultura de Lavras.

GHELFI FILHO, H. Efeito da irrigação sobre a produtividade do capim Elefante (Pennisetum purpureum Schum) variedade Napier. Piracicaba, 1972. 77p. Tese (Doutorado) - Escola Superior de Agricultura "Luiz de Queiroz" , Universidade de São Paulo.

GHELFI FILHO, H . Efeito da irrigação sobre o capim colonião (Panicum maximum Jacq.). O Solo, v.58, n.1, p.12-16, 1976.

GLORIA, N.A.da Adubação potássica de pastagens. In: PEIXOTO, A.M.; MOURA, J.C. de; FARIA, V.P. de (Ed.). Pastagens : fundamentos da exploração racional. 2.ed. Piracicaba: FEALQ, 1994. p. 189-196

GOERING, H.K.; SOEST, P.J. van. Forage fiber analyses: apparatus, reagents, procedures and some apllications. Washington: USDA, 1970. 20p. (USDA. Agricultural Handbook, 379). 
HAENLEIN G. F. W. Dairy management column - when is the best time to cut hay ?

Newark: University of Delaware, 1997. 2p.

HERLING,V.R.; PÁDUA, M.B. de; PAIVA, F.A. de; LUCHESI, M.M.; BATEMARQUES, V.G.; LUZ, P.H.de C.; LIMA, C.G. de Valor nutritivo da matéria seca disponível do capim-Mombaça (Panicum maximum Jacq.) sob pastejo. In: REUNIÃO ANUAL DA SOCIEDADE BRASILEIRA DE ZOOTECNIA, 37. Viçosa, 2000. Anais. Viçosa: SBZ, 2000. http://www.sbz.org.br/anais2000/Forragem/782.pdf (30 jul. 2002).

HERRERA, J.; JAQUINET, P.; CORONA, L. Efecto del regimen de riego sobre el rendimento y la utilizacion del agua en tres especies de pastos tropicales. Pastos $\mathbf{y}$ Forrajes, v.8, n.2, p. 25-45, 1985.

HODGSON, J.G. Grazing managent: science into practice. Essex: Longman Scientific and Technical, 1990. 203p.

HUMPHREYS, L.R. Tropical pasture utilisation. Cambridge: Cambridge University Press, 1991. 205p.

JANK, L. Melhoramento e seleção de variedade de Panicum maximum. In: SIMPÓSIO SOBRE MANEJO DA PASTAGEM, 12., Piracicaba, 1995. Anais. Piracicaba: FEALQ, 1995. p. 21-58.

JARVIS, S.C.; SCHOLEFIELD, D.; PAIN, B. Nitrogen cycling in grazing systems . In: BACON, P.E. Nitrogen fertilization in the environment. New York:Marcel Dekker, 1995. cap.10, p.381-419. 
JARVIS, S.C. Nitrogen management and sustainability. In: CHERNEY, J. H.; CHERNEY, D.J.R. (Ed.). Grass for dairy cattle New Yorker: CAB Publ., 1998. cap. 7, p.161-192.

JOAQUIN, B.M.; HERMÁNDEZ, A.; PÉREZ,J.; HERRERA, J.G.; GARCIA, G.; TREJO, C. Fertilización nitrogenada y momento de cosecha en el rendimiento y la calidad de semillas del pasto guinea (Panicum maximum Jacq.). Pasturas Tropicales, v.23, n.1, p.2-8, 2001.

KICHEL, A.N.; MIRANDA, C.H.B.; ZIMMER,A.H. Fatores de degradação de pastagem sob pastejo rotacionado com ênfase na fase de implantação . In: SIMPÓSIO SOBRE MANEJO DA PASTAGEM, 14., Piracicaba, 1997. Anais. Piracicaba: FEALQ , 1997. p. 193-211.

LADEIRA, N.P.; SYKES, D.J.; DAKER,A.; GOMIDE,J.A. Estudos sobre produção e irrigação dos capins pangola, sempre verde e gordura, durante o ano de 1965. Revista Ceres, v.12, n.74, p.105-116, 1966.

LIBARDI, P. L. Dinâmica da água no solo. Piracicaba : o autor, 1995. 497 p.

LIMA, S.C. Momitoramento da irrigação com o uso do tensiômetro. Fortaleza, 1999. 87 p. Dissertação (Mestrado) - Universidade Federal do Ceará.

LOURENÇO, L.F.; COELHO, R.D.; SORIA, L.G.T.;PINHEIRO,V.D.; CORSI,M. Coeficiente de cultura $(\mathrm{Hc})$ do capim Tanzânia (Panicum maximum Jacq.) irrigado por pivô central. In: REUNIÃO ANUAL DA SOCIEDADE BRASILEIRA DE ZOOTECNIA, 38., Piracicaba, 2001. A produção animal na visão dos brasileiros: anais . Piracicaba: SBZ, 2001. p.1013-1017. 
LUDLOW, M.M.; NG, T.T. Effect of water deficit on carbon dioxide exchange and leaf elongation rate of Panicum maximum var. trichoglume. . Australian Journal of Plant Physiology, v.3, p.401-413, 1976.

LUGÃO, S.M.B. Produção de forragem e desempenho animal em pastagens de Panicum maximum (Jacq.) (acesso BRA-006998) adubadas com nitrogênio na região do Noroeste do estado do Paraná. Jaboticabal, 2001. 151p. Tese (Doutorado) Faculdade de Ciências Agrárias e Veterinárias, Universidade Estadual Paulista "Júlio de Mesquita Filho".

MACHADO, R. C. R.; SOUZA, H. M. F.; MORENO, M.A.; ALVIM, P. T. Variáveis relacionadas com a tolerância de gramíneas forrageiras ao déficit hídrico. Pesquisa Agropecuária Brasileira, v.18, n.6, p.603-608, 1983.

MADAKADZE, I.C.; COULMAN, B.E.; PETERSON, P.; STEWART, K.A.; SAMSON, R.; SMITH, D.L. Leaf area development, light interception, and yield among Switchgrass populations in a short-season area. Crop Science, v.38, p. 827837, 1998.

MALAVOTA, E.; HAAG, H.P.; MELLO,F.A.F.; BRASIL SOBRINHO, M.O.C. Nutrição mineral e adubação de plantas cultivadas. São Paulo: Pioneira, 1974. $727 \mathrm{p}$.

MANNETJE, L.t'; PRITCHARD, A.J. The effect of daylength and temperature on introduced legumes and grasses for tropics and subtropics of Coastal Australia. I. Dry matter production, tillering and leaf area. Australian Journal of Experimental Agriculture and Animal Husbandry, v.14, p. 173-181, 1974. 
MARIA, I.C. de; ROSSETTO, R.; AMBROSANO, E.J.; CASTRO, O.M. de; NEPTUNE, A.M.L. Efeito da adição de diferentes fontes de cálcio no movimento de cátions em colunas de solo. Scientia Agricola, v.50, n.1, p. 13-26, 1993.

MARSHALL, T.J.; HOLMES, J.W. ; ROSE C.W. Soil physics. 3.ed. Cambridge: Cambridge University Press, 1999. 453p.

MARTELLO, V.P. Doses de nitrogênio para maximização da produção do capimelefante cv.Guaçu no período das secas.. Piaracicaba, 1999. 46p. Dissertação (Mestrado)- Escola Superior de Agricultura “Luiz de Queiroz”, Universidade de São Paulo.

MATTOS, H.B. de; WERNER, J. C. Efeito do nitrogênio e de leguminosas sobre a produção do capim-colonião (Panicum maximum Jacq.) Boletim de Indústria Animal, v.36, n.1, p.147-156, 1979.

MENEGATTI, D. P.; ROCHA, G.P.; PAIVA, P.C.A. ; MUNIZ, J.A. ; FURTINI NETO, A . E. Efeito de doses de nitrogênio sobre a produção de matéria seca e o valor nutritivo dos capins Coastcross, Tifton 68 e Tifton 85(1). In: REUNIÃO ANUAL DA SOCIEDADE BRASILEIRA DE ZOOTECNIA, 36, Porto Alegre, 1999. Anais. Porto Alegre:

SBZ, 1999. http://www.sbz.org.br/eventos/PORTOALEGRE/homepagesbz/FOR।FOR165.htm (30 jul. 2002)

MOLINARI, O . G. Grasslands and grasses of Puerto Rico. Rio Piedras: University of Puerto Rico, 1952. 167 p. (Bulletin, 102).

MONTEIRO, F.A. Nutrição mineral e adubação.. In: SIMPÓSIO SOBRE MANEJO DA PASTAGEM, 12. , Piracicaba, 1995. Anais. Piracicaba: FEALQ, 1995. p. 219244. 
MUCHOW, R. C.; SINCLAIR, T.R. ; BENNETT, J.M. Temperature and solar radiation effects on potencial maize yield across locations. Agronomy Journal, v.82, p.338343, 1990.

NABINGER, C. Eficiência do uso de pastagens: disponibilidade e perdas de forragem. In: SIMPÓSIO SOBRE MANEJO DA PASTAGEM, 14., Piracicaba, 1997. Anais. Piracicaba: FEALQ, 1997. p. 213-251.

NABINGER, C.; MEDEIROS, R.B. de Produção de sementes de Panicum maximum Jacq.. In: SIMPÓSIO SOBRE MANEJO DA PASTAGEM, 12., Piracicaba, 1995. Anais. Piracicaba: FEALQ, 1995. p. 59-128.

NG, T.T. ; WILSON, J.R.; LUDLOW, M.M. Influence of water stress on water relations and growth of a tropical $\left(\mathrm{C}_{4}\right)$ grass, Panicum maximum var. trichoglume. Australian Journal of Plant Physiology, v.2, p.581-595, 1975.

NASCIMENTO JUNIO R.; D., QUEIROZ, D.S.; SANTOS, M.V.F. Degradação das pastagens e critérios para avaliação. In: SIMPÓSIO SOBRE MANEJO DA PASTAGEM, 11., Piracicaba,1994. Anais Piracicaba:FEALQ, 1994. p. 129-156.

PACIULLO, D.S.C.; GOMIDE,J. A .; QUEIROZ,D.S.; SILVA, E.A . M. da Correlações entre características químicas, anatômicas e digestibilidade in vitro de gramíneas forrageiras. In: REUNIÃO ANUAL DA SOCIEDADE BRASILEIRA DE ZOOTECNIA, 37., Viçosa, 2000. Anais. Viçosa: SBZ, 2000. http://www.sbz.org.br/anais2000/Forragem/330.pdf (30 jul. 2002). 
PACIULLO, D.S.C.; MATTOS, J.L.S. de ; GOMIDE,J. A .; QUEIROZ,D.S.; SILVA, E.A . M. da Proporção de tecidos e espessura da parede celular em espécies de Braquiária, cultivadas sob diferentes níveis de umidade no solo. In: REUNIÃO ANUAL DA SOCIEDADE BRASILEIRA DE ZOOTECNIA, 36., Porto Alegre, 1999. Anais. Porto Alegre: 1999. http://www.sbz.org.br/eventos/PORTOALEGRE/homepagesbz/FOR।FOR059.htm (30 jul. 2002).

PATERSON, J.A.; BELYEA, J.P.; BOWMAN, J.P.;KERLEY,M.S.; WILLIAMS,J.E. The impact of forage quality and supplementation regimen on ruminant animal intake and performance. In: FAHEY Jr, G.C. Forage quality, evaluation, and utilization. Madison: ASA;CSSA;SSSA, 1994. p.59-114.

PEAKE, D.C.I.; MYERS, R.J.K.; HENZELL, E.F. Sown pasture production in relation to nitrogen fertilizer and rainfall in southern Queensland. Tropical Grasslands, v.24, p.291-298, 1990.

PEDREIRA, J.V.S. Crescimento estacional dos capins colonião (Panicum maximum Jacq.), Gordura ( Melinis minutiflora Pal de Beauv), Jaraguá (Hyparrhenia rufa (Ness) Stapf) e Pangola de Taiwan A-24 ( Digitaria pentzii Stent.). Boletim da Indústria Animal, v.30 n.1, p.59-145,1973.

PEREIRA, A.R.; VILLA NOVA, N. A.; SEDIYAMA, G. C. Evapo(transpi)ração. Piracicaba: FEALQ, 1997. 183p.

PÉREZ, A.; ACOSTA, R. Influencia de la norma y la frecuencia del riego sobre el rendimiento y la calidad em cuatro granineas. Pastos y Forrajes, v.9, n.3, p.244250, 1986. 
PÉREZ, A.; PÉREZ, G. Efecto del nitrogeno sobre los componentes del rendimento y la produccion de semillas de Guinea CIH 3 y Buffel CIH 2.. Pastos y Forrajes, v.15, n.3, p.225-232, 1992.

PETR.J.; CERNÝ,V.; HRUSKA,L. Yield formation in the main field crops. Amsterdam: Elsevier, 1988. 336p. (Developments in Crop Science , 13).

PIETERSE, P.A.; RETHMAN, N.F.G.; VAN BOSCH, J. Production, water use efficiency and quality of four cultivars of Panicum maximum at different levels of nitrogen fertilisation. Tropical Grasslands, v.31, p.117-123, 1997.

PINHEIRO, V.D. Viabilidade econômica da irrigação de pastagem de capim Tanzânia em diferentes regiões do Brasil. Piracicaba, 2002. 85 p. Dissertação (Mestrado) Escola Superior de Agricultura “Luiz de Queiroz”, Universidade de São Paulo.

PINTO, J.C.; GOMIDE, J.A.; MAESTRI, M. Produção de matéria seca e relação folha/caule de gramíneas forrageiras tropicais cultivadas em vasos, com duas doses de nitrogênio. Revista da Sociedade Brasileira de Zootecnia, v.23, n.3, p.313-326, 1994.

POWER, J.F. Response of semiarid grassland sites to nitrogen fertilization: I- Plant growth and water-use. Soil Science Society of America Journal, v.44, p.545-550, 1980a.

POWER, J.F. Response of semiarid grassland sites to nitrogen fertilization: II- Fertilizer Recovery. Soil Science Society of America Journal, v.44, p.550-555, 1980b.

POWER, J.F. Nitrogen- and water-use efficiency of several cool-season grasses receiving ammonium nitrate for 9 years. Agronomy Journal, v. 77, n.2, p.189-192, 1985. 
QUINLAN, T.J.; SHAW, K.A.; WARRELL, L.A. The effect of nitrogen on growth and chemical composition of irrigated Panicum maximum var. trichoglume cv. Petrie, Neonotonia wightii cv. Tinaroo on the Atherton Tableland, north Queesland. Tropical Grassland, v.15, n.1, p.27-30, 1981.

RAIJ, B. van. Fertilidade do solo e adubação. Piracicaba: Ceres;POTAFOS, 1991. 343 p.

RAMOS, A.K.B. Avaliação do crescimento, componentes produtivos e composição mineral de três gramíneas forrageiras tropicais. Piracicaba, 1997.152 p. Dissertação (Mestrado) - Escola Superior de Agricultura "Luiz de Queiroz", Universidade de São Paulo.

REICHARDT, K. Processos de transferência no sistema solo-planta-atmosfera. Campinas: Fundação Cargill, 1985. 445p.

REIS, S. T. dos Valor nutricional de gramíneas tropicais em diferentes idades de corte. Lavras, 2000. 99 p. Dissertação (Mestrado) - Universidade Federal de Lavras.

ROBERTS, J.; NAYAMUTH, R. A .; BATCHELOR, C.H.; SOOPRAMANIEN, G.C. Plant-water relations of sugar-cane (saccharum officinarum L.) under a range of irrigated treatments. Agricultural Water Management, v.17, p.95-115, 1990.

RODRIGUES, L.R.A.; RODRIGUES, T.J.D. Ecofisiologia de plantas forrageiras. In: CASTRO,P.R.C.; FERREIRA,S.O.; YAMADA,T. Ecofisiologia da produção agrícola. Piracicaba: Associação Brasileira para Pesquisa da Potassa e do Fosfato, 1987. p.203-230. 
RODRIGUES, L.R.A.; REIS, R.A. Bases para o estabelecimento do manejo de capins do gênero Panicum . In: SIMPÓSIO SOBRE MANEJO DA PASTAGEM, 12., Piracicaba, 1995. Anais. Piracicaba: FEALQ, 1995. p. 197-217.

RODRIGUES, L.R.A.; REIS, R.A. Conceituação e modalidades de sistemas intensivos de pastejo rotacionado. In: SIMPÓSIO SOBRE MANEJO DA PASTAGEM, 14., Piracicaba, 1997. Anais. Piracicaba: FEALQ, 1997. p.1-24.

ROLIM, F.A. Estacionalidade de produção de forrageiras. In: PEIXOTO, A.M.; MOURA, J.C. de; FARIA, V.P. de (Ed.). Pastagens: fundamentos da exploração racional. 2.ed. Piracicaba: FEALQ, 1994. p. 533-565

ROLIM, G.S.; SENTELHAS, P.C.; BARBIERI, V. Planilhas no ambiente EXCEL para os cálculos de balanços hídricos: normal, sequencial, de cultura e de produtividade real e potencial. Revista Brasileira de Agrometeorologia, v.6, p.133-137, 1998.

ROSSETO, F.A. A. Desempenho agronômico de pastagens de capim elefante cv. Guaçu (Pennisetum purpureum Schum,) e de capim Tanzânia (Panicum maximum Jacq.) em sistema de produção de leite. Piracicaba, 2000. 174p. Dissertação (Mestrado) Escola Superior de Agricultura “Luiz de Queiroz”, Universidade de São Paulo.

SANTOS, P.M. Estudo de algumas características agronômicas de Panicum maximum (Jacq.) cvs. Tanzânia e Mombaça para estabelecer seu manejo. Piracicaba, 1997. 62p. Dissertação (Mestrado) - Escola Superior de Agricultura "Luiz de Queiroz", Universidade de São Paulo.

SILVA, S.C. Condições edafo-climáticas para a produção de Panicum sp.. In: SIMPÓSIO SOBRE MANEJO DA PASTAGEM, 12., Piracicaba, 1995. Anais. Piracicaba: FEALQ, 1995. p. 129-146. 
SKERMAN, P.J.; RIVEROS, F. Gramíneas tropicales. Rome: FAO, 1992. 849 p. (FAO Producción y Protección Vegetal, 23)

SLATYER, R.O. Physiological significance of internal water relations to crop yield. In: EASTIN,J. D.; HASKINS, F.A.; SULLIVAN, C.Y.; BAVEL, C.H.M. van Physiological aspects of crop yield. Madison: American Society of Agronomy, 1969. cap.4, p.53-88.

STOUT, W.L. Water-use efficiency of grasses as affected by soil, nitrogen and temperature. Soil Science Society of America Journal, v.56, p.897-902, 1992.

STOUT, W.L.; JUNG, G.A.; SHAFFER, J.A. Effects of soil and nitrogen on water efficiency of Tall Fescue and Switchgrass under humid conditions. Soil Science Society of America Journal, v.52, p.429-434, 1988.

SUTCLIFFE, J. F. As plantas e a água São Paulo: EPU, 1980. 126 p. (Temas de Biologia , 23)

TAIZ, L.; ZEIGER,E. Plant physiology 2.ed. . Sunderland: Sinauer Associates., 1998. $792 p$.

TEIXEIRA, E.I. Avaliação de características morfofisiológicas e nutricionais do capim Tobiatã (Panicum maximum (Jacq.)cv. Tobiatã) sob sistema de pastejo rotacionado. Piaracicaba, 1998. 87p. Dissertação (Mestrado) - Escola Superior de Agricultura “Luiz de Queiroz”, Universidade de São Paulo.

TILLEY, J.M.A.; TERREY, R.A. A two stage techinique for the in vito digestion of forage crops. Journal of the British Grassland Society, v.18, p.104-112, 1963. 
TISDALE, S.L.; NELSON,W.L.; BEATON,J.D. Soil fertility and fertilizers . 4 ed., New York: Macmillan, 1985. 754p.

THORNTHWAITE, C.W. ; MATHER, J.R. The water balance. New Jersey: Drexel Institute of Technology , 1955. 104p. (Publications in Climatology)

TOZI, P. Estabelecimento de parâmetros agronômicos para o manejo e eficiência de utilização de Panicum maximum Jacq. cv. Tânzania 1 sob pastejo rotacionado. Piracicaba, 1999. 103p. Dissertação (Mestrado) - Escola Superior de Agricultura “Luiz de Queiroz”, Universidade de São Paulo.

VALLENTINE, J.F. Grazing management . San Diego: Academic Press, 1990. 533p.

VÁSQUEZ, R. Effects of irrigation and nitrogen levels on the yields of Guinea grass, Para grass, and Guinea Grass-Kudzu and Para grass-Kudzu mixtures in Lajas Valley. The Journal of Agriculture of the University of Puerto Rico, v.49, n.4, p.389-412, 1965.

VICENTE-CHANDLER, J. Intensive grassland management in Puerto Rico. Revista da Sociedade Brasileira de Zootecnia, v.2, n.2, p.173-215, 1973.

VICENTE-CHANDLER, J.; FIGARELLA, J.; SILVA, S. Effects of nitrogen fertilization and frequency of cutting on the yield and composition of Pangola grass in Puerto Rico. The Journal of Agriculture of the University of Puerto Rico, v.45, n.1, p.37-45, 1961 .

VICENTE-CHANDLER, J.; SILVA, S.; FIGARELLA, J. Effect of frequency of application on response of Guinea grass to nitrogen fertilization. The Journal of Agriculture of the University of Puerto Rico, v.46, n.4, p.343-349, 1962. 
VICENTE-CHANDLER, J.; SILVA, S.; ABRUÑA,F.; RODRÍGUEZ, A. Effects of two cutting heights, four harvest intervals and five nitrogen rates on yield and composition of Congo grass under humid tropical conditions. The Journal of Agriculture of the University of Puerto Rico, v.56, p.281-291, 1972.

ZHANG, H.; OWEIS,T.Y.; GARABET,S.; PALA,M. Water-use efficiency and transpiration efficiency of wheat under rain-fed conditions and supplemental irrigation in a Mediterranean-type environment. Plant and Soil, v.201, p.295-305, 1998.

WAGGONER, P. E. Environmental manipulation for higher yelds -15. In: EASTIN, J. D.; HASKINS, F.A.; SULlIVAN, C.Y.; VAN BAVEL, C.H.M (Ed.) Physiological aspects of crop yield. Madison: American Society of Agronomy; Crop Science Society of America, 1969. p.343-373.

WALES, W.J.; DOYLE, P.T.; DELLOW, D.W. Dry matter intake and nutrient selection by lactating cows grazing irrigated pastures at different pasture allowances in summer and auntumn. Australian Journal of Experimental Agriculture, v.38, p.451-460, 1998.

WENDLING, I.J.; GOMIDE, J.A. ; BRAZ, S.P.; SANTOS, H.Q. Consumo de forragem e produção de leite em pastagem de Brachiaria decumbens Staf. Adubada sob duas ofertas diária de forragem. In: REUNIÃO ANUAL DA SOCIEDADE BRASILEIRA DE ZOOTECNIA, 34., Juiz de Fora, 1997. Anais. Juiz de Fora: SBZ, 1997. http://www.sbz.org.br/scripts/anais1999/For/BFOR572.pdf. (30 jul. 2002 ).

WERNER, J.C. Estudo de épocas da adubação nitrogenada em capim colonião (Panicum maximum Jacq.) para aumento de produção de forragem nas secas. Boletim da Indústria Animal. , v. 27/28, p.361-367, 1970/1971. 
WERNER , J.C. Calagem para plantas forrageiras. In: PEIXOTO, A.M.; MOURA, J.C. de; FARIA, V.P. de (Ed.) Pastagens: fundamentos da exploração racional. 2.ed. Piracicaba: FEALQ, 1994. p. 111-120.

WERNER, J.C.; HAAG, H.P. Estudos sobre a nutrição mineral de alguns capins tropicais. Boletim da Indústria Animal v.29 n.1, p.191-245,1972.

WERNER, J.C.; COLOZZA, M.T.; MONTEIRO, F. A.. Adubação de pastagens. In: SIMPÓSIO SOBRE MANEJO DA PASTAGEM, 18., Piracicaba, 2001. Anais. Piracicaba: FEALQ, 2001, p. 129-156.

WERNER, J.C.; PAULINO, V.T.; CANTARELLA, H.; ANDRADE, N.O.; QUAGGIO, J.A. Forrageiras. In: RAIJ, B. van; CANTARELLA, H.; QUAGGIO, J.A. (Ed.) Recomendações de adubação e calagem. Campinas: IAC, 1996. p. 263-273. (IAC. Boletim, 100)

WILSON, J.R.; MANNETJE, L. t' Senescence, digestibility and carbohydrate content of Buffel grass and Green Panic leaves in Swards. Australian Journal of Agricultural Research, v.29, p.503-516,1978.

WILSON, J.R.; MINSON, D.J. Prospects for improving the digestibility and intake of tropical grasses. Tropical Grasslands, v.14, n.3, p.253-259, 1980

WHAtley, J.M.; WHATlEY, F. R. A luz e a vida das plantas. São Paulo: EPU, 1982. 101 p. (Temas de Biologia, 30). 